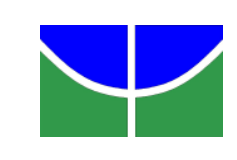

UNIVERSIDADE DE BRASÍLIA

FACULDADE DE DIREITO

PROGRAMA DE PÓS-GRADUAÇÃo

\title{
A CONSTITUIÇÃO DO ESTADO PLURINACIONAL DA BOLÍVIA COMO UM INSTRUMENTO DE HEGEMONIA DE UM PROJETO POPULAR NA AMÉRICA LATINA
}

GLADSTONE LEONEL DA SILVA JÚNIOR

Brasília 


\section{A CONSTITUIÇÃO DO ESTADO PLURINACIONAL DA BOLÍVIA COMO UM INSTRUMENTO DE HEGEMONIA DE UM PROJETO POPULAR NA AMÉRICA LATINA}

Tese apresentada ao Programa de Pós-Graduação da Faculdade de Direito da Universidade de Brasília como requisito para a obtenção do título de Doutor em Direito.

Área de concentração: Linha de Pesquisa 1 Pluralismo Jurídico e Direito Achado na Rua.

Orientadora: Prof. Dra. Alejandra Leonor Pascual.

\section{Brasília}




\section{A CONSTITUIÇÃO DO ESTADO PLURINACIONAL DA BOLÍVIA COMO UM INSTRUMENTO DE HEGEMONIA DE UM PROJETO POPULAR NA AMÉRICA LATINA}

Tese apresentada ao Programa de Pós-Graduação em Direito da Faculdade de Direito da Universidade de Brasília, para a obtenção do título de Doutor em Direito.

\section{BANCA EXAMINADORA}

Prof ${ }^{a}$. Dra ${ }^{\mathrm{a}}$. Alejandra Leonor Pascual Orientadora - Universidade de Brasília (UnB)

\begin{tabular}{c}
\hline $\begin{array}{c}\text { Prof. Dr. José Geraldo de Sousa Júnior } \\
\text { Universidade de Brasília (UnB) }\end{array}$ \\
\hline $\begin{array}{c}\text { Prof. Dr. Alexandre Bernardino Costa } \\
\text { Universidade de Brasília (UnB) }\end{array}$ \\
Prof. Dr. Rubén Martínez Dalmau \\
Universitat de València - (UV/Espanha) - (Membro Externo). \\
Universidade Federal de Minas Gerais (UFMG) - (Membro Externo). \\
Prof. Dr. José Luiz Quadros de Magalhães \\
Prof. Dr. Alexandre Araújo Costa \\
Universidade de Brasília (UnB) - (Membro Suplente).
\end{tabular}

Brasília, 08 de dezembro de 2014. 
Ao povo latino-americano. 


\section{AGRADECIMENTOS}

Esse momento requer um retrospecto com um grau de reflexão interessante sobre o balanço de tudo o que aconteceu até hoje. Mesmo que não fosse claro, anos atrás, que eu terminaria um doutorado, essa foi a única atividade na minha vida que eu sempre tive clareza que deveria fazer para qualificar minha atuação nas causas que defendo e vivencio. Pois bem, até aqui as coisas foram minimamente planejadas, depois disso o destino, amparado por esse acúmulo histórico, dirá.

Como essa reflexão agradecida transcende o período doutoral parto da minha família, em sentido estrito, o clã Bonfim-Leonel. Meu pai (Gladstone), minha mãe e revisora ortográfica (Sandra), minha irmã (Rayana), meu irmãos (Felipe e Roberto). O tempo talvez seja a forma mais sábia de lidar com as escolhas. Eu as tomei em determinado momento da vida com a ajuda vocês e crença absoluta que poderia dar certo, mesmo que não fossem as escolhas que tomariam. Passados todos esses anos, hoje elas resultam em algo concreto, uma pessoa com a cabeça mais aberta, o espírito mais tolerante e as convicções mais claras e fortalecidas. Assim, forja-se um projeto de vida.

A linha de gratidão segue por toda Minas Gerais indo de Gov. Valadares, permeada por minha vó Aracy, jovem há mais tempo, ao Davizinho, recém-chegado, até o conforto familiar em Piumhi. Talvez os/as envolvidos/as não compreendam o conteúdo da tese ou simplesmente discordem (caso compreendam), mas certamente entendem a importância desse momento.

A partir daqui sigo a concepção de manifestar gratidão pela ótica da família ampliada. Assim, desde já agradeço a todos aqueles/as que permanecem desde os tempos de Viçosa, os/as quais ainda guardo comigo, pois sabem que todo esse projeto iniciou-se lá. Aqueles/as presentes em Curitiba e, posteriormente, em Franca também tiveram papel fundamental em toda essa construção histórica e qualidade de vida. Várias dessas pessoas e momentos contribuíram para o salto ao doutorado.

A chegada em Brasília com um projeto de pensar a América Latina, sobretudo, a Bolívia e seu processo de luta foi prontamente amparado pela professora e amiga Alejandra Pascual. O seu entusiasmo e energia possibilitou um andamento adequado e consistente que partiu de um projeto cheio de ideias e tornou-se uma tese. Projeto que não existiria, se não tivesse um contato anterior com o país pesquisado, em uma viagem realizada em 2010, a qual marcou o início do segundo mandato de Evo Morales e 01 ano da promulgação da nova Constituição. A companhia de Luciana Carvalho nessa viagem e em jornadas anteriores, também contribuiu e marcou o caráter desse projeto. Impossível deixar de destacar a influência que continuou presente de Elisabete Maniglia e Antonio A. Machado no prosseguimento desse caminho, 
sendo para mim grandes legados pessoais da UNESP que levo com carinho e admiração. A parcela da família Leonel que vive em Brasília merece destaque. Tia Regina e o seu tempero mineiro me acolheu, literalmente como um mineiro acolhe o outro, no seio do seu lar. Ali meu afeto só aumentou por todas as minhas primas Leonel e os queridos agregados. O que dizer então, de Antonio Escrivão Filho, ou Tuco, que chega em Brasília no mesmo ano que eu e com fé na vida recompomos laços de uma amizade iniciada no encontro da RENAP em 2005. Alimentamos uma relação fraternal pura, que oscila momentos de referencia paternal à busca de conselhos dados, como um filho. Uma presença central para se construir uma tese consistente e para a autoconstrução como ser humano. Igor Lima, ou Vaca, companheiro que ajudou no início dessa caminhada de Brasília. Rodrigo Mesquita "amigo novo, parceiro novo", que do Piauí nos ajuda a ressignificar Brasília e a conceber novos projetos.

Brasília é a cidade que permite dar razão à Vinícius de Moraes quando afirma que "A vida é a arte do encontro/embora haja tanto desencontro pela vida". Pois, ela insiste em reencontros de vida e de almas. Essa materialização ocorre a todo o momento, Patrick Mariano, Heloisa Gimenez, Talita Rampin, Diego Diehl, Henrique Reis, Marleide Rocha, Maria Mello, Fairuze Aziz, Vinicius Fialho, Március Crispim, Nei, Palominha, Poninha, Isis, Kassabs, Marmotta, Foca, Dendê, Ru, Nagô, Samantha, Sandrão, Paola Alves, Kátia Fontes, Matheus Lage, Fred, Lu Pivato, Lud, Flavinha Carlet, povo da Consulta Popular e do escritório do MST e tantos outros/as felizmente são provas vivas disso e continuam imprescindíveis. O reencontro de alma se dá com aquelas pessoas as quais nos perguntamos: - Como não o/a conhecia antes? E obviamente tornaram-se fundamentais. Sandra Silva, Mayrá Lima, Gisele Barbieri, Sérgio Sauer, Acácio Briozo, Gaga Leão, Hamú (ou Carzalberto), Valdirene, Luisa Valle, Lívia Nascimento, Débora Cruz, Leo Cabral, Gabi e Bárbara Batista, Tia, Fucão, Bico Bonecini, Gil, Guigo, Thiago, Ale Lehmann, Rui, Hugo Nister, Dara, Bia B., Fábio K, Giu, Rodrigo Souto, Atahualpa, Isadora Sousa, Liu Leal, Carlão Odas, Lucas Camarotti, Pedroca, Leonor, Letícia Lengruber, Cecília, Matheus Utzig, Yussef, João do Cavaco, Bira e Rose, Marcelo Arruda, Camila Bonassa, Humbertinho, Raphael Seabra, Pedro B, Neneto, Edu Mendez, Ju Amoretti, Leo Menezes, Douglas Zaidan, Carina Calabria, Eduardinho Rocha, Lu Ramos, Marta Gama, Dani Felix, Gabriel Sampaio, Mari, Vlad, Sassá, Rê, Fê, Kiki, Laís, Aline, Rodrigo "Serna", Camila Gomes, Carol, Paulinha, Carlos Ron, Pedrão de Sanca, Edu Borges, João Gabriel, Érika, Telésforo, Capela, Diana Melo, Ju Acosta, Betinho Góes, Katia Azambuja, Clara Cardoso, Ágata Ferraz, Andreia Marreiro, Dani Turati, grupo de capoeira Beribazu e muitos outros e outras.

Certamente, o samba do Peleja e os envolvidos/as no mesmo merecem um capítulo a parte. Até porque grande parte, deles e delas, está comigo no decorrer da minha vida em momentos para além do peleja. Peleja é luta, é catarse coletiva, é o transe pessoal e a celebração da vida entre 
amigos/as. Todo meu tempo no peleja tive e tenho muitos ensinamentos. Só não aprendi a tocar, nem a cantar direito ainda. Parte dos pelejeiros me ensinaram, inclusive, que o carnaval de Olinda/Recife poderia ser melhor do que os outros que eu já tinha vivido e acertaram em cheio. Destaque para a escalação do time: Fernando Antunes no gol. Jonas Valente, João Francisco, Gésio e Marcos Urupá formam a linha de zaga. O meio é composto por Pirulito, Jacson Segundo, Vinicinho Mansur e Rogério Tomaz. O ataque é formado por Flávio CR7 e Felipe Danziato. Quem não gostaria de compor esse time? Brincadeiras a parte, vocês tem uma importância que não conseguem dimensionar. Sou grato por tudo! Parafraseando mais uma vez o poetinha, em "Samba da benção" ao referir-se à Tom Jobim demarca: "Parceiro e amigo querido/que já viajaste tantas canções comigo/e ainda há tantas por viajar". É o que espero dos amigos/as pelejeiros/as.

Não deixaria de destacar a fundamental pesquisa de campo realizada na Bolívia, o acolhimento e o aprendizado precioso com Sue lamamoto e Rafaela Pannain. Estendo meus cumprimentos a todos/as entrevistados dos movimentos sociais, do Estado e sociedade civil em geral, que contribuíram bastante para o aprimoramento da tese. As viagens pela América Latina foram fundamentais para adentrar mais à realidade do nosso povo e o doutorado sanduíche na Universidade de Valencia, Espanha, importante no refinamento da análise constitucional. Daí o agradecimento ao meu co-orientador Rubén Martínez Dalmau e a CAPES que financiou toda a minha vida acadêmica.

A Universidade de Brasília foi a minha segunda casa ao longo dos últimos 04 anos. Dessa forma sou grato aqueles/as que sempre me ajudaram e ainda me ajudam nessa trajetória acadêmico-profissional. Aos amigos Alexandre Bernardino Costa ou ABC, José Geraldo de Sousa Júnior e Alexandre Araújo Costa referências na academia e na vida. Aos outros professores que convivi mais intensamente no meu período de docência na UnB, Beatriz Vargas, Othon Azevedo, Cláudia Roesler, Argemiro, Mamede Said, Cristina Zackseski, Marcelo Neves, Gabriela Delgado, Ela Wiecko, Menelick de Carvalho, Evandro Piza, Cláudio Ladeira, meu muito obrigado. Além desses agradeço de coração aos funcionários da secretaria de graduação e da pós-graduação da UnB, e em nome da querida Helena e do Carlinhos estendo meu agradecimento a todos os outros. Cada um com um papel fundamental e carinho especial para tratar um doutorando e professor substituto da forma devida e acolhedora. Juntamente com eles, agradeço todos os meus alunos e alunas da graduação da UnB. Não tenham dúvidas que meu aprendizado com vocês foi muito maior do que o proporcionado por mim no papel de docente. Essa experiência ficará guardada com muito afeto e sempre servirá de parâmetro no exercício da minha profissão.

Com a benção do meu pai Xangô e da minha mãe lemanjá, agora o que me resta é caminhar! 
"Ao Sul, a repressão. Ao Norte, a depressão. Não são poucos os intelectuais do Norte que se casam com as revoluções do Sul só pelo prazer de ficarem viúvos. [...] A moda do Norte, moda universal, celebra a arte neutra e aplaude a víbora que morde a própria cauda e acha que é saborosa. Acultura e a política se converteram em artigos de consumo. Os presidentes são eleitos pela televisão, como os sabonetes, e os poetas cumprem uma função decorativa. Não há maior magia que a magia do mercado, nem heróis mais heróis que os banqueiros. A democracia é um luxo do Norte. Ao Sul é permitido o espetáculo, que não é negado a ninguém. E ninguém se incomoda muito, afinal, que a política seja democrática, desde que a economia não o seja. Quando as cortinas se fecham no palco, uma vez que os votos foram depositados nas urnas, a realidade impõe a lei do mais forte, que é a lei do dinheiro. Assim determina a ordem natural das coisas. No Sul do mundo, ensina o sistema, a violência e a fome não pertencem à história, mas à natureza, e a justiça e a liberdade foram condenadas a odiar-se entre si." (2002, p. 108).

EDUARDO GALEANO, Mapa-Múndi/2, O Livro dos Abraços 
LEONEL JÚNIOR, Gladstone. A Constituição do Estado Plurinacional da Bolívia como um instrumento de hegemonia de um projeto popular na América Latina. 2014. 345 f. Tese (Doutorado em Direito) - Faculdade de Direito, Universidade de Brasília, Brasília, 2014.

\section{RESUMO}

O ano de 2009 apresenta uma novidade na dinâmica político-jurídica latinoamericana: uma Constituição concebida para um Estado que se declara Plurinacional, sendo assim promulgada a Constituição do Estado Plurinacional da Bolívia. Esta pesquisa apresenta os conceitos trabalhados ao longo da tese, por meio de uma perspectiva transformadora e, em parte, de uma epistemologia do sul. Ademais, discute o contexto sociopolítico boliviano no século XX para adentrar a análise da atualidade. Todo o quadro exposto é permeado pela análise do Direito, do Estado e, sobretudo, da Constituição como categorias ontologicamente liberais, ainda utilizadas. Contudo, apresenta-se a crítica liberal e o novo constitucionalismo latino-americano é situado como uma percepção jurídica adequada ao contexto insurrecional boliviano. Alguns pontos centrais como democracia, autonomia, jurisdições, descolonização e economia são abordados tanto no que se refere ao texto constitucional, quanto ao exercício no período pós-constitucional. Dessa forma, é possível ter um panorama geral a respeito da profundidade das transformações políticas e jurídicas no país referido, suas contradições atuais, e verificar até que ponto a Constituição do Estado Plurinacional da Bolívia serve como um instrumento de um projeto popular na América Latina.

Palavras-chave: Constituição; Estado Plurinacional da Bolívia; hegemonia; projeto popular; América Latina. 


\begin{abstract}
The year 2009 presents a novelty in Latin American political and legal dynamics: a Constitution designed for a State that declares itself as Plurinational. Being enacted the Constitution of the Plurinational State of Bolivia. This research presents the concepts used throughout the thesis from a transformative perspective and, in part, from an epistemology of the South. Moreover, this research discusses the Bolivian sociopolitical context in the twentieth century, in order to start off an analysis of today. The scenario mentioned above is permeated by the analysis of the law, the state and, especially, the Constitution as ontologically liberal categories, still in use. However, the liberal critique is presented and the new Latin American constitutionalism is understood as an appropriate legal perception to the Bolivian insurrectionary context. Some key points such as democracy, autonomy, jurisdictions, decolonization and economy are addressed in the constitutional text, as its exercise in the post-constitutional period. Thus, it is possible to have an overview about the depth of the political and legal transformations in the country concerned, its current contradictions, and verify to what extent the Constitution of the Plurinational State of Bolivia serves as instrument of a popular project in Latin America.
\end{abstract}

Keywords: Constitution; Plurinational State of Bolivia; hegemony; popular project; Latin America. 


\section{RESUMEN}

El año 2009 presenta una novedad en las dinámicas políticas y jurídicas de América Latina: una Constitución diseñada para un Estado que se declara Plurinacional. Se promulgó la Constitución del Estado Plurinacional de Bolivia. Esa investigación presenta los conceptos utilizados en la tesis, desde una perspectiva transformadora y, en parte, una epistemología del Sur. Además, discute el contexto socio-político boliviano en el siglo XX para entrar en el examen de la actualidad. Todo el cuadro de arriba está permeado por el análisis de la ley, del estado y sobre todo de la Constitución como categorías ontológicamente liberales, todavía se utiliza. Sin embargo, la crítica liberal se presenta y el nuevo constitucionalismo latinoamericano situado como una visión jurídica apropiada para el contexto insurreccional boliviano. Algunos puntos clave como: la democracia, la autonomía, las jurisdicciones, la descolonización y la economía se abordan tanto en relación con el texto constitucional, como en su ejercicio en el período post-constitucional. Por lo tanto, es posible tener una visión general acerca de la profundidad de las transformaciones políticas y jurídicas en el país en cuestión, las contradicciones actuales, y ver hasta qué punto la Constitución del Estado Plurinacional de Bolivia sirve como instrumento de un proyecto popular en América Latina.

Palabras clave: Constitución; Estado Plurinacional de Bolivia; hegemonía; proyecto popular; América Latina. 


\section{LISTA DE ILUSTRAÇÕES}

Tabela 01 - Descrição das exportações bolivianas em 2012

Foto 01 - População toma o escritório da empresa Águas de Tunari em Cochabamba.

Foto 02 - Guerra do Gás.

Foto 03 - Guerra do Gás.

Foto 04 - O efetivo das Forças Armadas e os representantes dos povos indígenas em demonstração de unidade em Santa Cruz de la Sierra.

Foto 05 - Evo Morales, presidente indígena eleito na Bolívia e Sílvia Lazarte, eleita a primeira mulher-indígena presidenta da Assembleia Constituinte.

Tabela 02 - Quantidade de congressistas eleitos na constituinte por partidos.

Tabela 03 - Cronograma de debates sobre o programa constitucional nos Departamentos.

Foto 06 - Oruro, 09 de dezembro de 2007, dois terços dos congressistas presentes aprovaram os 411 artigos da Nova Constituição Política do Estado. Artigos que ainda seriam alterados posteriormente.

Tabela 04 - Resultado do Referendo Constituinte de 2009.

Foto 07 - O presidente mostra a nova Carta Magna aos cidadãos depois de promulgá-la. 
Foto 08 - O Ingresso dos constituintes do MAS com a bandeira tradicional e a wiphala para exporem sua visão de país na sessão plenária de 7 de março de 2007.

Foto 09 - O Vice-presidente Álvaro García Linera explica o acordo alcançado sobre as autonomias. Projetam-se quatro niveles: o departamental, o regional ou provincial, o municipal y o indígena.

Tabela 05 - A organização territorial na nova Constituição Política do Estado.

Tabela 06 - Quantidade de contraentes do programa "Matrimonios colectivos desde nuestra identidad".

Tabela 07 - Fases da estratégia de industrialização dos recursos evaporíticos.

Tabela 08 - Sais minerais obtidos com a construção das piscinas de evaporação.

Tabela 09 - Municípios que optaram por converter-se em autonomias indígenas originárias campesinas.

Foto 10 - Autoridades originárias recebem a declaração de constitucionalidade do estatuto autonômico de Totora.

Tabela 10 - Consultas públicas realizadas em 2011 aos povos e nações indígenas.

Tabela 11 - Princípios regentes emergentes do bloco de constitucionalidade.

Tabela 12 - Porcentagem de votos nas eleições para os órgãos de Justiça na Bolívia. 


\section{SUMÁRIO}

INTRODUÇÃO 16

\section{CAPÍTULO 1 ELEMENTOS DE UMA EPISTEMOLOGIA TRANSFORMADORA}

DO SUL NA CONFIGURAÇÃO DO ATOR COLETIVO DA HIPERPOTENTIA LATINO-AMERICANA: DA CONSTRUÇÃO DE UMA NOVA HEGEMONIA NA AMÉRICA LATINA A PARTIR DA EXPERIÊNCIA BOLIVIANA

1.1 Características do processo civilizatório latino-americano e a importância da uma emancipação unitária

1.2 Elementos fundamentais para uma epistemologia transformadora do sul.

1.2.1 Aspectos da modernidade, da colonialidade do poder e o mito da integração cultural na formação dos Estados-nação na América Latina

1.2.2 O imperialismo e a dependência latino-americana 40

1.2.3 A ideia de partido, o bloco histórico e a hegemonia diante da realidade dos Estados do Sul

1.30 ator coletivo da hiperpotentia como desencadeador da práxis libertadora na realidade latino-americana

1.3.1 Os postulados políticos da hiperpotentia como estímulo à construção de um novo paradigma político

1.40 contexto sociopolítico boliviano e os seus sinais transformadores

1.4.1 As formas de organização social na Bolívia

1.4.2 Aspectos da estrutura capitalista boliviana no século XX: um enfoque marxista a partir dos Grundrisse. 
1.4.3 O Katarismo e o resgate da identidade indígena rebelde no contexto democrático liberal

1.4.4.1 As lutas populares e a formação do bloco histórico contrahegemônico subalterno ou o bloco indígena-popular 94

1.4.4.1.1 A guerra da água 95

1.4.4.1.2 A guerra do gás. 98

1.4.4.1.3 Mais mobilizações, o diagnóstico e o efeito das lutas populares com a eleição de Evo Morales 102

1.4.4.2 A nacionalização dos hidrocarbonetos e a demanda pela constituinte 106

\section{CAPÍTULO 2 A CRÍTICA À CONSTRUÇÃO LIBERAL DO DIREITO E O NOVO CONSTITUCIONALISMO LATINO-AMERICANO: A EXPERIÊNCIA DA CONSTITUIÇÃO POLÍTICA DO ESTADO PLURINACIONAL DA BOLÍVIA}

2.1 o paradigma político do direito como fundamento do constitucionalismo moderno e das teorias jurídicas hegemônicas

2.1.1 A análise geral dos paradigmas a partir do estudo de Thomas Kuhn e os seus desdobramentos no mundo do direito 115

2.1.2 Crítica à modernidade e ao paradigma jurídico hegemônico diante da realidade da América Latina: a necessidade de uma concepção transmoderna e transontológica do direito 121

2.1.3 A importância da transformação paradigmática do sistema de direitos 125

2.2 A concepção de Estado de Direito e a insuficiência das instituições para uma análise jurídico-transformadora da América Latina

2.2.1 O contexto institucional e o direito moderno: a crítica ontológica desde o Outro. 
2.2.2 A dinâmica de desenvolvimento do Estado de Direito e a crítica à manutenção da estrutura liberal para a garantia de direitos.

2.2.3 Da dialética à analética social do direito: contribuições de Lyra Filho e Enrique Dussel

2.30 novo constitucionalismo latino-americano

2.3.1 Da perspectiva histórica constitucional da América até o novo constitucionalismo latino-americano

2.3.2 As características próprias do novo constitucionalismo latino-americano e a Constituição do Estado Plurinacional da Bolívia .

2.3.2.1 O contexto do processo constituinte boliviano

2.3.2.2 Os aspectos formais característicos da nova Constituição Política do Estado Boliviano.

2.3.2.3 Os elementos estruturantes da nova Constituição Política do Estado Boliviano 195

2.3.2.3.1 A diversidade democrática na Constituição boliviana. 196

2.3.2.3.2 Autonomia e reorganização territorial do Estado 201

2.3.2.3.3 A reestruturação jurisdicional 206

2.3.2.3.4 Os caminhos rumo à descolonização constitucional e a plurinacionalidade.

\section{CAPÍTULO 3 PARA UMA NOVA PERSPECTIVA CONSTITUCIONAL NA AMÉRICA LATINA: AS POSSIBILIDADES E OS DESAFIOS A PARTIR DA EXPERIÊNCIA BOLIVIANA}

\subsection{A consolidação revolucionária para a refundação do Estado boliviano} desde a descolonização e a plurinacionalidade 
3.1.1 As ações da descolonização cultural e da despatriarcalização 236

3.1.2 A plurinacionalidade como opção política real em variados setores 239

3.2 A economia e o vivir bien em tempos de Estado Plurinacional

3.2.1 A dura tarefa da modificação da estrutura econômica ao longo do processo transformador

3.2.2 A nacionalização de setores estratégicos e o investimento na produção como formas iniciais de alteração do padrão econômico

3.2.3 O fortalecimento da pluralidade econômica como próxima etapa para possibilitar a materialização do vivir bien

3.3 O processo concreto das autonomias e a questão agrária na reordenação territorial boliviana

3.3.1 Uma proposta agrária antimonopólica e saneadora de terras

3.3.2 Os entraves e a implantação da autonomia como elemento chave da plurinacionalidade.

3.4 Os aspectos jurisdicionais conflitivos na Bolívia atual 276

3.4.1 O largo caminho para o aperfeiçoamento e aplicação da jurisdição indígena originária campesina.

3.4.2 A formação do Tribunal Constitucional Plurinacional e as eleições no sistema de Justiça boliviano

3.5 A democracia a partir de uma nova institucionalidade

3.5.1 O fortalecimento de uma legitimidade democrática para acabar com a cultura dos Golpes de Estado

3.5.2 A busca por uma democracia intercultural popular em um ambiente predominantemente liberal e capitalista.

3.6 A Constituição Plurinacional e o Estado de Transição: o socialismo comunitário no horizonte 


\section{ANEXOS}

ANEXO-A - Ata de cômputo nacional das eleições gerais de 2005

ANEXO-B - Gazeta oficial da Bolívia com a decretação do referendo amparado pela lei 3850

ANEXO-C - Documento assinado pelas organizações pelo Pacto de Unidade

ANEXO-D- Assembleia Nacional de Organizações Indígenas Originarias, Campesina y de Colonizadores da Bolívia. 05 de agosto de 2006

ANEXO-E - Despacho do comando da Polícia nacional à Presidenta da Assembleia constituinte

ANEXO-F - Acordo final da mesa de diálogo nacional estabelecida

ANEXO-G - Cédula do referendo que limitou a propriedade à 5 mil hectares no máximo e aprovou a Constituição

ANEXO-H - Acordo sobre o Sistema Econômico na Constituição, reconhecendo a economia plural. La Paz, 04 de outubro de 2007.

ANEXO- I - Distribuição departamental da população de acordo com a sua condição étnico-linguística

ANEXO- J - Mapa, ainda no início dos anos 2000 , que indica as áreas na Bolívia formadas por Terras Comunitárias de Origem (TCO).

ANEXO- $L$ - Membros de povos e nações indígenas componentes das Assembleias Legislativas Plurinacional, Departamental e Regional do Chaco.

ANEXO- M - Autoridades Judiciais eleitas no sufrágio de 2011 


\section{INTRODUÇÃO}

"Nas Américas, a cultura real é filha de várias mães. Nossa identidade, que é múltipla, realiza sua vitalidade criadora a partir da fecunda contradição das partes que a integram. Mas temos sido adestrados para não nos enxergarmos. [...] $\mathrm{Na}$ verdade, a raiz indígena ou a raiz africana, e em alguns países as duas ao mesmo tempo, florescem com tanta força como a raiz europeia nos jardins da cultura mestiça”. (2013, p. 58-59).

EDUARDO GALEANO. De pernas pro ar: a escola do mundo ao avesso.

Todo texto constitucional é moldado pela correlação de forças e é permeado pelas narrativas políticas predominantes no período histórico em que a Constituição é elaborada. Na Bolívia, a promulgação da Constituição Política do Estado, em 2009, nutre a fusão de um sonho revolucionário à necessidade de colocar esses anseios transformadores em andamento.

Refletir sobre certas categorias políticas e jurídicas (como direito, Estado e Constituição) no contexto de uma alteração social tão intensa e rápida representa um desafio peculiar na medida em que essas categorias inspiram as mudanças ao mesmo tempo que são ressignificadas ao longo do processo. As palavras permanecem, mas o sentido delas é alterado ao longo dos processos que elas próprias contribuem para engendrar (na medida que organizam discursos e interações sociais), em uma relação complexa que desafia reflexões que tentam reduzir essa circularidade a uma causalidade linear, seja em uma tentativa materialista vulgar de entender que as categorias são meros epifenômenos resultantes do processo histórico ou na tentativa idealista de ler o processo como uma realização dos princípios que lhe são imanentes.

Os discursos somente existem de forma concreta: são enunciados emitidos de fato, em contextos determinados, com toda a finitude e limitação de 
um acontecimento. Os discursos não realizam as categorias abstratas da modernidade, mas operam uma rede de categorias de modo a produzir interações sociais mediadas por significados que reforçam ou rejeitam certos modos de organização social. A ordem do discurso não é simplesmente uma organização abstrata de significados linguísticos, mas uma organização concreta de interações sociais mediadas também por significados linguísticos. O reconhecimento de que essas categorias em transformação, Direito, Estado e Constituição, ao mesmo tempo influenciam e são influenciadas pelas relações historicamente construídas oferece uma chave de compreensão importante para que possamos enfrentar 0 desafio de entender o sentido desses conceitos dentro do contexto histórico em que elas afloram.

Ao enfrentar o desafio de caracterizar esses institutos em seu movimento de transformação, a presente pesquisa precisa lidar com alguns desafios de modo crítico e consciente.

a) A capacidade de interpretar a sociedade;

b) A base programática para a mudança pleiteada;

c) A construção hegemônica a partir da interpretação com uma capacidade real de agregar outros grupos ao projeto político renovador;

d) A presença de grupos e organizações políticas e sociais com legitimidade moral para forjar e sustentar esse processo transformador, detendo capacidade de exercer e dirigir a luta popular.

Esses elementos direcionarão a análise das mudanças aqui constatadas, a considerar o contexto político boliviano, e a partir da Constituição promulgada em 2009 como objeto central para essa verificação. As referências utilizadas, em grande parte desse trabalho, possuem bases marxistas e marxianas ${ }^{1}$, inclusive quanto ao método pautado no materialismo histórico ${ }^{2}$. Há uma intencionalidade em trazer a dinâmica dialética às situações

\footnotetext{
1 Aqueles indivíduos que utilizam a construção teórico-metodológica de Karl Marx para desenvolverem sua linha pensamento e ação.

${ }^{2}$ Para o materialismo histórico, as condições da vida têm como força principal o modo de produção dos bens materiais: "o modo de produção da vida material condiciona o processo em geral de vida social, político e espiritual" (MARX, 1978a, p. 129).
} 
reais e concretas como base e forma de abordagem do conhecimento trabalhado. Essa dialética a partir de uma percepção marxista, a conjugar a realidade latino-americana, além da luta de classes trata das lutas dos grupos sociais para reafirmar a igualdade social e de oportunidades em uma sociedade diversa e "abigarrada".

Nesse caso "a escolha dos problemas a serem estudados não se efetua a partir de um conjunto de hipóteses previamente estabelecidas pelos pesquisadores, mas tem sua origem nas situações sociais concretas", em que caberá ao pesquisador que participa do processo investigativo a compreensão do fenômeno (BARBIER, 1985, p. 151). A captação do contexto histórico e político da Bolívia são fundamentais para entender os efeitos hodiernos de determinadas situações recentes que repercutem na vida do povo boliviano. Assim, um modelo metodológico marxista, mesmo sendo estrutural, se apoiará também na análise de dados históricos específicos e qualitativos que terão a função de recontar o passado, apreender os principais acontecimentos e compreender os fenômenos recorrentes. De fato, isso é o que procuro fazer ao longo da pesquisa de campo na Bolívia. As entrevistas, através de um formato semidiretivo com um roteiro já preparado, são usadas como tentativa de interação social para captar o real, objetivando situações correntes. A busca por referências bibliográficas in loco e a história oral preocupar-se-ão com o que é relevante para a compreensão da sociedade e não tratará de agregar toda e qualquer informação de forma dispersa e desarrazoada. Ademais, realizou-se a observação direta e coleta de documentos ao longo da pesquisa de campo, na descrição de elementos objetivos ali colocados, em uma situação e contexto social concreto (HAGUETTE, 2001). Desses pontos e através desses instrumentos realizou-se a "pesquisa-participante".

\footnotetext{
${ }^{3}$ Por falta de uma tradução mais adequada, a expressão constantemente utilizada pelo intelectual boliviano Rene Zavaleta Mercado, traz um significado dessa palavra que se aproxima de heterogênea, referindo-se à sociedade boliviana. Álvaro Garcia Linera trata o termo como "a coexistência sobreposta de vários modos de produção, de vários tempos históricos e sistemas políticos." (tradução livre). (GARCIA LINERA, 2008, p. 230).

4 Tereza Haguette opta por reservar o termo pesquisa-ação para as práticas de origem europeia, e pesquisa-participante para àquelas direcionadas à América Latina, pois a gravidade dos conflitos sociais estaria exigindo um novo padrão de desenvolvimento científico aqui,
} 
A estudiosa do campo da metodologia, Teresa Haguette, parte de alguns pressupostos epistemológicos, os quais dialogam com a proposta dessa pesquisa-participante.

1) A objetividade - separação entre o sujeito e o objeto não é necessária no processo de conhecimento;

2) o momento do conhecimento poderá coincidir com o momento de mudança;

3) a neutralidade não é necessária no processo de conhecimento: a ciência deve tomar o partido dos homens e não de alguns homens;

4) a generalização na sociedade é problemática: as sociedades atuais são muito diferenciadas e o processo de mudança muito rápido (2001, p. 138).

Esses pontos servem para caracterizar bem o trajeto desse trabalho. A pesquisa permitirá a produção de conhecimentos que tendem a ser úteis e proeminentes para a prática política e social tratada.

Dessa forma, a estrutura da tese busca separá-la em três capítulos a partir de intencionalidades bem evidentes, como a distinção temática e temporal. Na primeira parte, tratar-se-á de elencar e esmiuçar aspectos epistemológicos adequados ao objetivo do trabalho e categorias do conhecimento utilizadas ao longo da tese, sobretudo a partir de marcos teóricos marxianos/as e do próprio Karl Marx, conforme já referido. Assim, já sinaliza a forma de abordagem das mesmas sem a necessidade de uma contínua repetição da explicação dos conceitos ao utilizá-los. Ademais, a abordagem do contexto histórico latino-americano, agregado à formação do seu povo e os momentos históricos insurrecionais, são pressupostos destacados para ingressar na análise sociopolítica boliviana e seus sinais transformadores. Ali destacam-se as formas de organização social e sua implicados devem elaborar e trabalhar uma estratégia de mudança social." (CHIZZOTTI, 2006, p.90). 
dinâmica. As formas comunitárias de produção e reprodução da vida de diversas comunidades e nações indígenas convivem com um modo de produção capitalista dependente, o qual possibilitou o aumento do número de trabalhadores/as assalariados. Esses/as atuando, sobretudo, em setores da economia primária, como a mineração, e no decorrer do período neoliberal fragmentam-se atuando no trabalho informal próximo aos grandes centros urbanos. Essa classe trabalhadora formada pela lógica capitalista regional atrelada à condição identitária e cultural do povo boliviano ressalta-se também pela cor da pele e natureza do nome (TEJADA, 2012, p. 236). Na Bolívia a noção de nação e classe seguem juntas. Ao adentrar nessa seara alcançando à eleição de Evo Morales, atinge-se o objetivo da primeira parte que é o de realizar essa contextualização histórico-epistemológica até o período da Assembleia Constituinte em 2006.

A segunda parte trará alguns discursos críticos paradigmáticos à construção ontológica do Direito, do Estado e da Constituição. Ao realizar uma pesquisa-participante institucional, como ocorre nessa parte, justamente por englobar esse campo institucional, "trata-se de desconstruir, através de um método analítico, a rede de significações das quais a instituição é portadora, enquanto célula simbólica" (BARBIER, 1985, p. 156-157). Isso possibilitará, no capítulo seguinte, falar em refundação do Estado, por exemplo. Em decorrência dessa análise se conformará a abordagem jurídica através de uma analética social do direito, amparada por autores como Enrique Dussel e Roberto Lyra Filho. Após esse momento ingressar-se-á no novo constitucionalismo latinoamericano e suas peculiaridades e possibilidades. Daí, após o processo constituinte torna-se possível analisar a Constituição promulgada no ano de 2009, objeto da pesquisa, em sua dimensão normativa. Ali serão pinçados pontos centrais, a partir dos desafios e necessidades sócio-históricas de países como a Bolívia, que se pauta por um projeto popular atualmente, e examinada a abordagem desses pontos no texto constitucional.

Por fim, a terceira parte tem a função de verificar se o conteúdo e a reestrutura constitucional boliviana foram implementados na práxis e até que ponto contribuiu como instrumento para a hegemonia de um projeto popular na 
América Latina. Para isso, valer-se-á também das entrevistas realizadas, focadas em intelectuais-orgânicos ${ }^{5}$ do período de conflitos antagônicos frente ao bloco da elite econômica, interessados em aprofundar o processo transformador boliviano. Atualmente, alguns apoiam e constroem, já outros criticam os rumos do processo político. Alguns desses intelectuais falam de um processo revolucionário, ao tratarem da nova conformação do Estado Boliviano. De fato, visto que as tarefas democráticas, nacionais e populares, não foram cumpridas pelos governos anteriores, essas se tornam pautas de uma luta revolucionária com todas as contradições que possam apresentar. Ademais, em um contexto de países periféricos no sistema-mundo essas bandeiras assumem perspectivas anticapitalistas e anti-imperialistas para a respectiva efetivação das mesmas.

Ao tratar a importância em conceber um projeto popular, o que se pretende é observar até que ponto a sociedade boliviana organiza-se em torno de interesses que estimulam o potencial humano e os valores de grupos e organizações sociais que se reproduzem culturalmente e vivem do trabalho, ou seja, aqueles que compõem a grande maioria do povo. A consolidação desse projeto popular ocorre ao materializar a força social do povo através da execução do seu programa político. A Bolívia, como os outros países latinoamericanos, ainda necessita aprofundar transformações centrais para as mudanças estruturais que trazem esse formato do projeto popular. A tendência, ao seguir os compromissos para o êxito de um projeto desse tipo, é uma maior democratização de pontos estratégicos, como a riqueza, a terra, a cultura, as comunicações e a informação, entre outros. Além da importância em criar mecanismos de participação e construção social a partir da formação do povo, assim, dando mais espaços, no caso boliviano, à concepção institucional e dinâmica social desde os diversos povos indígenas, mestiços, camponeses e trabalhadores/as responsáveis pela construção da riqueza e sujeitos fundamentais do povo para a transformação da Bolívia.

\footnotetext{
${ }^{5}$ Gramsci define como intelectuais aqueles grupos sociais que, mesmo não formando uma classe, atuam no nível superestrutural e tratam de organizar a hegemonia de um grupo. Como ele mesmo afirma: "Não existe uma classe independente de intelectuais, pois cada classe tem seus intelectuais" (Tradução Livre) (GRAMSCI, 1981a, p. 107-108.).
} 
Nesse momento apontar-se-ão rupturas que indicam o reconhecimento concreto e o modo como surge o Estado Plurinacional, para além da mera previsão constitucional. Interessa-nos dar visibilidade à esses diversos pontos, mais do que aprofundar as especificidades de cada temática constitucional. A intenção é demonstrar o processo jurídico-político envolvido, bem como todas as contradições e conflitos na conformação desse novo cenário, e dessa forma contribuir para o debate sobre a Constituição Boliviana e, consequentemente, sobre o contexto da América Latina.

A proposta desse estudo não é, tão só, enaltecer, tampouco escarnecer o processo político que advêm das lutas populares e é legitimado com a promulgação constitucional. No entanto, através do suporte teóricometodológico utilizado, o qual incorpora uma proposta de transformação social, verificar até que ponto isso é realizado na Bolívia, mesmo que em um curto período de vigência constitucional. 
CAPÍTULO I - ELEMENTOS DE UMA EPISTEMOLOGIA TRANSFORMADORA DO SUL NA CONFIGURAÇÃO DO ATOR COLETIVO DA HIPERPOTENTIA LATINO-AMERICANA: DA CONSTRUÇÃO DE UMA NOVA HEGEMONIA NA AMÉRICA LATINA A PARTIR DA EXPERIÊNCIA BOLIVIANA.

"O mapa-múndi que nos ensinaram dá dois terços para o norte e um terço para o sul. No mapa, a Europa é mais extensa do que a América Latina, embora, na verdade, a América Latina tenha o dobro da superfície da Europa. [...] O mapa mente. A geografia tradicional rouba o espaço, assim como a economia imperial rouba a riqueza, a história oficial rouba a memória e a cultura formal rouba a palavra." (2013, p. 323).

EDUARDO GALEANO. Mapa-Múndi, De pernas pro ar: a escola do mundo ao avesso.

Em trechos da obra de Karl Marx, O Capital, observa-se que a centralidade temática da teoria não se concentra na análise dos capitalistas ou operários, mas está no estudo do próprio capital. Objeto este que, inversamente ao ser humano que tem o trabalho reificado no capitalismo, passa a ter "vida própria" em uma perspectiva de humanização da sua existência.

Para reverter esta lógica, que se baseia em uma relação de exploração do ser humano para um maior acúmulo da taxa de lucro de alguns poucos detentores dos meios de produção, os marxistas acreditam na potencialidade transformadora do sujeito revolucionário. Esse terá o papel histórico de reverter esta lógica e implementar um outro sistema, o socialista. Para Marx, este sujeito revolucionário está centrado na figura do proletariado industrial assalariado, conforme, juntamente com Engels, apresenta no Manifesto do Partido Comunista (1986). A partir deste grupo, poderá irradiar-se a ruptura sistêmica e a estruturação de uma nova sociedade fomentadora de valores 
próprios. Certamente, ao longo da vida e dos estudos, Marx vai refinando a análise e as possibilidades incorporadas à realidade desse sujeito, através da atenção ao desenvolvimento desigual do capitalismo, o que é observado em outras obras, sobretudo, ao final de sua vida ${ }^{6}$.

Já Lenin, aliou o sujeito proletário russo ao campesinato, predominante quantitativamente naquela época, para levar adiante a Revolução Russa. Esta união teve uma representação simbólica na própria bandeira da União Soviética ao trazer o martelo e a foice. O marxista italiano Antônio Gramsci chega a ressaltar a importância da formação do novo bloco histórico pensado a partir da figura do proletariado revolucionário.

Todos estes valorosos pensadores e militantes da causa comunista fizeram leituras de um sujeito revolucionário específico que poderia encadear um processo profundamente transformador na Europa, e no mundo. Contudo, foram figuras importantes que analisaram a necessidade da Revolução Socialista a partir da Europa.

Assim, não descartando as reflexões realizadas, mas agregando-Ihes novos elementos, caberá aos latino-americanos identificar quais seriam os sujeitos revolucionários capazes de subverter o sistema capitalista vigente e seus meios de dominação na estrutura política vivenciada, se pretendem construir um novo tipo de Estado e sociedade. Reformulando assim, esse sujeito transformador, concebido diante de uma perspectiva própria da realidade e passando de mera reprodução de categorias europeias para 0 contexto concreto da América Latina.

Nessa proposta, Darcy Ribeiro, José Carlos Mariátegui, e Enrique Dussel com alguns outros intelectuais, compõem um grupo de pensadores que passam a construir seus estudos partindo da, e para a América Latina. Este último trabalha com o conceito de hiperpotentia. Originalmente o termo é

\footnotetext{
${ }^{6}$ Cf. MARX, Karl. A questão irlandesa. Trad. Alexandre Linares. 1869. Disponível em: http://marxists.org/portugues/marx/1869/11/questao.htm. 2004. Acesso em 15 jan. 2014; MARX, Karl. Primeiro projeto de resposta à Carta de Vera Zassúlitch. 1881. Trad. José Barata-Moura. Editorial Avante, Edições Progresso: Lisboa, 1982. Disponível em: http://marxists.org/portugues/marx/1881/03/vera.htm. Acesso em: 15 jan. 2014.
} 
trazido por Spinoza e remodelado por Dussel (2007), o qual constitui um poder emergente do povo capaz de grandes transformações em momentos criadores da história. Este conceito possibilitará analisar o desenvolvimento das peculiaridades dos atores coletivos, potencialmente construtores de uma nova hegemonia, inclusive jurídica, e de um projeto de sociedade emancipatória latino-americana. Além da hiperpotentia, tratar da América Latina nos impõe revisitar nossas bases epistemológicas, visto que será analisada uma realidade própria desde uma perspectiva transformadora. Assim, uma tarefa a ser cumprida será resgatar algumas categorias e remodelar outras.

O sujeito revolucionário ou transformador da realidade latino-americana age em um contexto político, social, econômico e cultural próprio. As características que permeiam o processo histórico da América Latina devem ser compreendidas para que se entendam os efeitos gerados atualmente por essa conjuntura, além da possibilidade de transformá-lo.

Uma vez reconfigurada a leitura do processo civilizatório (RIBEIRO, 1983b), debatendo o tema por meio de categorias que trabalham bases epistemológicas transformadoras desde a realidade latino-americana, caberá analisar a experiência boliviana e suas particularidades dentro do processo e dos objetivos apresentados.

\subsection{Características do processo civilizatório latino-americano e a importância da uma emancipação unitária}

Em seu vasto estudo, Darcy Ribeiro preocupou-se em trilhar os caminhos de um processo civilizatório na história mundial para, a partir das constatações averiguadas, analisar a América Latina. As dificuldades de desenvolvimento com que os povos latinos defrontam-se decorrem de 
inúmeros elementos, entre eles, uma falta de compreensão de suas características e formações. Somente com um olhar direcionado se poderá pensar um processo de libertação e concepção de um projeto popular na América Latina a partir da potencialidade de seu povo.

Os latino-americanos possuem características que os une, apesar de não uniformizá-los. "Amalgamando gente procedente de todos os quadrantes da Terra, criaram-se aqui povos mestiços que guardam em seus rostos étnicosculturais heranças tomadas de todas as matrizes da humanidade" (RIBEIRO, 1986, p. 17-18). Contudo, a formação do povo latino-americano deve ser contada e compreendida com base na estruturação do processo civilizatório mundial e não com a mera chegada dos europeus à América.

A partir do surgimento dos primeiros núcleos agrícolas, há alguns milênios, inicia-se o que pode ser considerado o início de um processo civilizatório no mundo. A região difusora destas práticas, onde se constatou pela primeira vez esses núcleos, foram a Mesopotâmia e, posteriormente, o Egito.

Antes dessa Revolução Agrícola, o homem habitava em pequenos grupos vivendo de coleta e caça em uma dinâmica de vida instável. Após essa etapa, com o surgimento de inovações tecnológicas, houve um incremento da produtividade, a qual decorria do trabalho humano propiciando um desenvolvimento urbano. Nesse cenário, houve a possibilidade de garantir colheitas mais fartas, as quais viabilizaram essa nova formação social. Há quem defenda que a partir dessa etapa do desenvolvimento histórico-evolutivo, inicia-se o que foi entendido, mais a frente como a separação da sociedade entre classes sociais ${ }^{7}$.

\footnotetext{
7 "Das primitivas comunidades agrícolas igualitárias e das hordas pastoris, fundadas ambas na propriedade coletiva da terra e dos rebanhos e na garantia a cada unidade familiar dos produtos do seu trabalho, passa-se, assim, progressivamente, a sociedade de classe, assentadas na propriedade privada ou em outras formas de apropriação e de acumulação do produto do trabalho social. Umas e outras tornam-se cada vez menos solidárias internamente, porque as relações entre pessoas, antes reguladas pelo parentesco, começam a ser condicionadas por considerações de ordem econômica." (RIBEIRO, 1983b, p. 75.).
} 
Aos poucos a vida urbana desenvolve-se, não só nesses centros, mas expande-se rumo ao Oriente até chegar ao que hoje conhecemos como América, e muito antes da vinda dos colonizadores europeus.

Primeiro, as cidades-Estados que inauguram a vida plenamente urbana, com base na agricultura de regadio e em sistemas sócio-econômicos coletivistas, antes de 4000 a.C. na Mesopotâmia (Halat); entre 4000 e 3000 a.C. no Egito (Mênfis, Tebas); na Índia (Mohenjo-Daro, por volta de 2800 a.C.); antes de 2000 a.C. na China (Yang-Shao, Hsia); e, muito mais tarde, na Transcaucásia (Urartu, 1000 a.C.); na Arábia Meridional (Hajar Bin Humeid 1000 a.C.); na Indochina (Khmer, 500 a.C., Champa, 700 E.C., Annan, 1000 E.C., Sião, 1200 E.C.); e ainda, no Altiplano Andino (Salinar e Galinazo, 700 a.C., e Mochicha, 200 E.C); na Meso-América (Uxmal, 300 E.C.); na Colômbia (Chibcha, 1000 E.C.); no primeiro milênio de nossa era no Japão (Jimmu), reiterando-se diversas vezes (Heian, 782 E.C.; Kamakura, 120 E.C). (RIBEIRO, 1983b, p. 80).

Assim, observa-se a vinda de comunidades, minimamente organizadas no continente americano centenas de anos antes da chegada europeia. Ali, já se desenvolviam práticas culturais e sociais próprias a partir da dinâmica de vida local. A chegada desses grupos à América precedeu ao que Darcy Ribeiro concebeu como a ocorrência de uma Revolução de Regadio, com o surgimento de Impérios Teocráticos também nas Américas com os Maias, os Incas e os Astecas. Sociedades essas, estruturadas em uma dinâmica própria de vida aqui existente, em que as disputas de poder entre os seus grupos formadores eram frequentes ao seu desenvolvimento ${ }^{8}$.

O escritor boliviano, Jorge Soruco, atribui à mística da cosmovisão andina construída a partir dos Impérios Teocráticos Incas como meio discursivo para assegurar poderes à uma elite existente. Evidencia-se uma forma

\footnotetext{
8 "Un Imperio y un Estado como el Inca no se edificó en torno del reino mágico de la "armonía social" y "la reciprocidad horizontal", como pretenden hacernos creer hoy los filósofos de la cultura y antropólogos del "mundo andino", sino que es el resultado de la generación de un excedente económico, el surgimiento de antagonismos sociales y la emergencia de clases 0 castas privilegiadas al interior de la sociedad; (...)" (SORUCO, 2009, p. 13).
} 
diferenciada da relação homem-natureza entre esses povos. Contudo, a religião foi além da mera reprodução mística, segundo o autor.

La religión del Tawantinsuyo - dice Mariátegui - no estaba hecha de complicadas abstracciones, sino de sencillas categorías. (...) La religión, por tanto, juega un papel ideológico central en la visión política de las elites Incas, el Estado incaico se identifica con el Inca quien a través de éste controla el trabajo sobre la tierra, la circulación de bienes y los tributos de las comunidades y pueblos sometidos a lo largo del imperio (SORUCO, 2009, p. 23).

Além das grandes obras arquitetônicas desenvolvidas nessa época, a economia desses impérios era movimentada internamente com sistemas de irrigação adequados à geografia e ao clima da região. As redes de comunicação também eram estimuladas e diversificadas de acordo com 0 desenvolvimento urbano local. Tudo isso configurava uma forma própria de desenvolvimento de alguns povos da América. Como destaca Galeano; havia "de tudo entre os indígenas da América: astrónomos e canibais, engenheiros e selvagens da idade da pedra. Mas, nenhuma cultura nativa conhecia o ferro nem o arado, nem o vidro, nem a pólvora, nem empregavam a roda”. (tradução livre) (2010, p. 33).

Somente com a expansão do capitalismo mercantil, estimulador das grandes navegações ibéricas, que outra forma de organização social desenvolveu-se na América. Aliás, esse processo de expansão europeia, que partiu da península ibérica à América e ocorre também pela Rússia com a chegada ao que hoje é o Alasca, estrutura as bases da primeira civilização mundial.

Essa civilização traz à América uma modernidade altamente violenta e exploratória. A racionalidade trazida emergiu com o mito sacrificial dos povos originários. As consequências imediatas à invasão ibérica foram nefastas e trágicas, como, pontualmente, descreve Eduardo Galeano em, As Veias abertas da América Latina; "Muitos indígenas de Dominicana se antecipavam 
ao destino imposto por seus novos opressores brancos: matavam os seus filhos e suicidavam em massa" (Tradução Livre) (2010, p. 31).

A exploração de metais preciosos na América Latina foi diretamente responsável pela grande impulsão da industrialização inglesa e a ocorrência da Revolução Industrial. O domínio imperialista já estava em pleno andamento e suas etapas sendo aplicadas.

\begin{abstract}
A implantação imperialista se dá em 3 etapas, na medida em que os sistemas de exploração externa que desenvolve alteram suas formas de ação e alargam seus interesses. Na primeira etapa, atua pela exportação de manufaturas e pela conquista de fontes privativas de matérias-primas ou de mercados cativos, sucedendo nesta função às antigas formações mercantis, seja mediante a imposição do estatuto colonial, seja através de procedimentos neocoloniais. $\mathrm{Na}$ segunda, correspondente à função das empresas em grandes monopólios controlados por agências financeiras, passa a atuar principalmente pela exportação de capitais na forma de equipamento modernizador da infra-estrutura produtiva das nações atrasadas e de capitais de empréstimo a governos. [...] $\mathrm{Na}$ terceira etapa, os procedimentos financeiros são suplantados em favor da instalação, nos países dependentes, de subsidiárias das grandes corporações monopolistas, como dispositivos de exploração de riquezas minerais e de produção industrial para o mercado interno, com o fim de drenar os capitais gerados nas nações pobres para enriquecer ainda mais as nações opulentas (RIBEIRO, 1983b, p. 155).
\end{abstract}

No entanto, as classes dominantes da América Latina assumem um formato anacrônico. A formação vai desde uma camada conservadora de proprietários de terra e outros meios de produção até uma elite capitalista modernizadora que também é proprietária ou controladora dos meios de produção e que na atualidade é parcialmente estrangeira. Assim, o povo latinoamericano terá que enfrentar tanto um projeto de sociedade conservadora e atrasada, que ainda tem força, quanto reverter a perspectiva avassaladora de aprofundamento do capitalismo para outro projeto político de sociedade de cunho popular. 
Se seguirmos a formação econômico-social de concepção marxista, preconizada por Friedrich Engels no século XIX, em que diferencia cinco formações do modo de produção (o Comunismo Primitivo, o Escravismo, o Feudalismo, o Capitalismo e o Socialismo) (ENGELS, 2002) resta um a ser realizado, o socialismo. ${ }^{9}$ Alia-se um modo de produção concreto à uma organização social estabelecida a partir da ideologia de grupos hegemônicos. No entanto, para falar na necessidade de outro projeto político para a América Latina, advindo de uma ruptura com a formação atual, devemos nos perguntar, o que nos unifica?

Apesar da continuidade continental, ainda não há um ente sóciopolítico atuante, o qual expresse toda a potencialidade exarada pelos povos aqui viventes. De cordilheiras imponentes à florestas impenetráveis, a densidade e diversidade climática e geográfica nem sempre contribuem para um intercâmbio maior entre os povos.

Mesmo assim, a latino-americanidade é uma identidade perceptível mundo a fora. Distingue-nos sem maiores dubiedades dos povos da América anglo-saxônica. Esse contraste entre as Américas ajuda a desvendar o que nos une quanto latino-americanos ao defrontarmos os aspectos culturais, sociais e econômicos entre uns e outros. Observa-se que existem muito mais características em comum do que divergências.

O mote que opera na América Latina, forjando assim a sua "uniformidade cultural e prometendo concretizar amanhã sua unidade sóciopolítica e econômica, reside no fato de sermos o produto de um mesmo processo civilizatório - a expansão ibérica" (RIBEIRO, 1986, p. 22).

A miscigenação é uma constante na América Latina, mesmo que conformada em tons e intensidades variadas. Isso é verificável, seja com uma maior formação popular indígena em locais como os altiplanos andinos, ou a prevalência negra no Caribe e nas Guianas, a predominância étnica europeia

\footnotetext{
${ }^{9}$ Não podemos falar em regimes feudais típicos na América Latina. O capitalismo absorveu-o, mesmo que julguemos algumas práticas realizadas aqui como pseudo-feudais.
} 
em países como Uruguai e Argentina e até mesmo uma mescla de raças e cores em um país-continente como o Brasil.

Assim, desde o domínio dos Impérios Espanhol e Português nos países latino-americanos, o desenvolvimento do colonialismo, sejam nas instituições de poder, na produção de conhecimento e diversos outros setores, potencializou-se. Ainda hoje, observam-se suas variadas facetas de reprodução.

Uma das formas históricas de reprodução na realidade andina ocorreu ainda com a chegada dos espanhóis no século XVI. Os colonizadores observaram outras formas de expansão do seu domínio, que não necessitasse partir tão só para o extermínio ou a mera escravização das populações locais. Aproveitando tratar-se de povos que respeitavam hierarquias sociais estabelecidas, visto que viviam sob o auspício de um império próprio, o Inca; os espanhóis utilizaram de mecanismos que reproduzissem um domínio, agora sob o comando da metrópole europeia ${ }^{10}$. Assim, após derrotarem a resistência de imperadores e grupos incas, sem maiores problemas, pois os incas passavam por conflitos internos recentes ${ }^{11}$, alguns grupos da elite inca foram cooptados.

\footnotetext{
10 "Para mostrar tanto su obediencia a ley natural como para limitar el control que españoles particulares tenían sobre la población indígena andina, la corona estableció bajo Felipe II un sistema de gobierno colonial que colocaba el mando (y la recolección de tributos) de comunidades indias particulares bajo el control de una nobleza indígena, un estrato privilegiado a través de cual la corona podría conducir a los pueblos andinos de a barbarie pagana a la civilización cristiana. (...) la elite india ocupaba una posición liminar en el ordenamiento colonial, en la frontera entre las dos republicas. Sus privilegios y su autoridad se derivaban al mismo tiempo de sus raíces en la república de indios y de su obligación de hacer que la sociedad indígena se adecuara a los ideales españoles. Se tratara ya de los incas del Cuzco o de los grandes señores aimaras de la cuenca del Titicaca, lo cierto es que las elites indias fundaban su precedencia hereditaria en unos antepasados que databan del tiempo de la gentileza, pero para su preparación dependían de la estructura legal y la organización económica del virreinato del Perú" (GARRET, 2009, p. 19).

11 "Al encontrar un imperio escindido por la guerra civil, los españoles rápidamente quebraron las redes imperiales de los incas y empujaron los Andes a la anarquía. En 1532 se encontraron con Atahualpa en Cajamarca, donde lo hicieron prisionero (...). El dominio imperial incaico jamás se recuperó de la guerra entre Atahualpa y Huáscar, y después de la década de 1530, los incas - tanto las redes imperiales como la confederación étnica del Cuzco - dejaron de conformar un grupo o lugar de poder unificado en los Andes." (GARRET, 2009, p. 43-47).
} 
Com o Império Inca derrotado, a então nobreza inca, que se alia aos espanhóis, passa a constituir-se como engrenagens fundamentais para a reprodução da lógica colonial europeia sob uma roupagem própria, uma vez que exercida pelos próprios indígenas andinos. A monarquia espanhola criou a figura dos "caciques". Indígenas que passaram a compor a nobreza dentro da colônia, submetidos à metrópole, os quais cobravam tributos de alguma unidade sócio-territorial, que presidiam. Literalmente, um processo de reprodução da colonialidade do poder.

Esse mecanismo dominador e reprodutor do colonialismo tinha, além do cacique, a figura do corregedor que era responsável pelo acompanhamento do trabalho dos caciques, auxiliando a coroa. Esse era um cargo, geralmente ocupado por espanhóis ou descendentes desses. Esta relação entre caciques e corregedores gerou alguns problemas, os quais desembocaram em grandes rebeliões, no século XVIII ${ }^{12}$. Além, disso, a população que estava sob o julgo do cacique poderia eventualmente recorrer aos Tribunais caso houvesse abusos na sua ação.

A área de domínio espanhol abrangeu grande parte do Império Inca, o qual partia do Alto do Peru até o Norte da Argentina, passando pela Bolívia. O império europeu soube aproveitar a estrutura social já existente para desenvolver as práticas coloniais e o mercantilismo.

Da mesma forma, o processo exploratório em que a América Latina foi submetida é muito diverso ao processo da América anglo-saxônica. Enquanto uma desenvolveu-se acumulando divisas e impondo-se economicamente perante os outros países, a outra América teve sua economia subjugada ao bel-prazer dos países com economias mais poderosas, mantendo-se como mero exportador de commodities e fornecendo matéria-prima e mão-de-obra para esses detentores do poder. Ou seja, mesmo que existam grandes diferenças econômicas entre os países latino-americanos, todos eles ainda

\footnotetext{
${ }^{12}$ Referimo-nos às rebeliões encabeçadas por Tupac Amaru e Tupac Catari, decorrentes de uma relação conflituosa da atividade dos caciques, o que abriu o caminho décadas mais tarde para o enfraquecimento do Império Espanhol e os processos de independência.
} 
cumprem um papel subalterno na divisão internacional do trabalho, e fomentam um capitalismo dependente.

Nos Estados Unidos, por exemplo, "os índios não eram parte da população incorporada ao espaço de dominação colonial britânico-americana." (QUIJANO, 2005, p. 120). Já no início da configuração Estado-nação eles são excluídos, depois o território em que viviam foi invadido e, por fim, foram exterminados. Os negros sofrem uma relação colonial de dominação ao serem trazidos da África. Em meados do século XIX dá-se uma reidentificação nacional de povos distintos, sobretudo através da participação democrática para os recém-chegados (TOCQUEVILLE apud QUIJANO, 2005, p. 120), mantendo uma hegemonia entre os brancos, que eram maioria da população.

Esse processo colonizador com caráter mais democrático para a maioria da população, que era branca nos Estados Unidos, aponta diferenças elementares da colonização na maioria dos outros países da América Latina. $\mathrm{Na}$ Bolívia, objeto de nosso estudo, a população sempre foi majoritariamente formada por indígenas e mestiços. Mesmo assim, a maior parte da população era impedida de participar e atuar diretamente na organização social e política do Estado-nação que ali era formado. Assim, a minoria branca da Bolívia assumiu o controle do Estado e não possibilitou a democratização de setores fundamentais na sociedade, como ocorreu nos Estados Unidos entre a maioria branca.

O que se observa é a formação de um Estado baseada na dominação colonial de índios, mestiços e negros. Logo, criam-se Estados aparentemente independentes diante de sociedades coloniais, pois tampouco poderiam ser consideradas, de fato, nacionais, nem democráticas. Por essa minoria branca, não possuir os mesmo interesses que a maioria dos outros nacionais que ali viviam, reproduziam sua condição senhorial à população, sendo sequer capaz de desenvolver mais vigorosamente os mecanismos impulsionadores do capitalismo, para não perder a "qualidade" de senhores. Assim, mantiveram a escravidão e trabalhos servis por um largo período e não potencializaram o trabalho assalariado e criação de mercado interno, na busca da mera 
manutenção dos privilégios históricos. "Quando, muito mais tarde, foi necessário libertar os escravos, não foi para assalariá-los, mas para substituílos por trabalhadores imigrantes europeus e asiáticos.” (QUIJANO, 2005, p. 123). A colonialidade do poder era manifestada, justamente na identificação dos interesses da minoria branca dominante boliviana com os brancos dominantes europeus e estadunidenses. Não havia nenhum interesse social comum, nem nacional, entre os grupos dominantes da Bolívia e até mesmo de outros países da América Latina. Somente vigorava a exclusão absoluta da maioria do povo e a construção aparente de um Estado-nação forjado artificialmente.

Assim, as mazelas sociais na América Latina, diferentemente da América anglo-saxônica, são mais frequentes, numerosas, intensas e aprofundadas na composição da sociedade, atreladas a essa estrutura colonial de poder, historicamente constituída, e à dinâmica de reprodução capitalista imposta. A fome, a miséria, o analfabetismo, o não acesso à saúde ou ao esporte perpetuam-se em larga escala.

Por essas e outras, a América Latina deve travar uma luta emancipatória conjunta, avançando sob a dominação histórica e não reproduzindo a lógica liberal e violenta do capitalismo, mas propondo o novo. Uma política nova, a partir do homem/mulher novo/a, tão propalado por Ernesto Che Guevara, construindo uma nova América. A Revolução, qualquer que seja seu formato, será inevitável para esta nova etapa (SADER, 2004).

Já Darcy Ribeiro, em uma de suas obras, trata o socialismo como "a mais capaz das formas de prover os sistemas impessoais de controle tornados indispensáveis para fazer os homens mais livres e mais responsáveis no mundo da abundância, estimulando sua capacidade criadora [...]" (1983b, p. 202). A pessoa humana é tida como o meio e o fim do que considera como processo de humanização.

No bojo deste novo processo civilizatório, a América Latina volta a tempos bolivarianos. Novamente são chamadas à cena 
as tensões estruturais antioligárquicas e anticoloniais que espocaram tantas vezes em guerras de emancipação e em sublevações milenaristas de escravos, de índios e de camponeses. [...] Isto porque a tarefa das forças revolucionárias foi afinal definida: é a da conquista do poder político por vanguardas socialistas capazes de reestruturar toda a ordem social, de erradicar as constrições econômicas representadas pelos interesses oligárquicos e imperialistas, de liquidar o despotismo do velho patriciado civil e militar para, deste modo, por fim aos fatores causais do atraso que pesa há séculos sobre os povos latino-americanos (RIBEIRO, 1983a, p. 258).

\subsection{Elementos fundamentais para uma epistemologia transformadora do sul.}

1.2.1. Aspectos da modernidade, da colonialidade do poder e o mito da integração cultural na formação dos Estados-nação na América Latina.

Ao tratar de uma epistemologia transformadora do sul, indico a utilização de categorias e saberes, os quais buscarão trilhar a construção do conhecimento a partir da realidade colonial e explorada do sul com o objetivo de modificar o status quo constituído historicamente, através do subsídio de um projeto popular. Existem alguns exemplos de linhas de pensamento que contribuíram para a transformação epistemológica na América Latina, como a teoria da dependência, a teologia da libertação dentre outras.

Não entrarei no debate feito por Walter Mignolo ao diferenciar a epistemologia da gnosiologia, pontuando essa como uma forma de conhecimento para além das culturas acadêmicas (MIGNOLO, 2003, p. 30-31). Por entender que a epistemologia pode romper com seus próprios pressupostos de construção concebendo saberes transformadores, a partir da construção social humana. Talvez, a utilização epistêmica no caso dessa tese aproxima-se com o que o intelectual argentino conceitua como gnose liminar, 
"enquanto conhecimento desde uma perspectiva subalterna, colocando em primeiro plano a força e criatividade dos saberes, consistindo em conhecimento formulado desde as margens externas do sistema mundial colonial/moderno." (MIGNOLO, 2003, p. 34). Assim, a descolonização dos saberes tanto quanto a descolonização política e econômica é passível de realização.

Certamente, uma epistemologia transformadora do sul não deve negar categorias que trabalham desde uma perspectiva de universalidade crítica, conforme exemplificado por algumas correntes marxistas, pois servem de base para o acúmulo de um conhecimento de ruptura, porém agregado às questões ligadas a essa realidade regional.

Ao analisar um processo de transformação em um país latinoamericano, como a Bolívia, cabe observar como foram concebidas as estruturas de poder nesse lado do mundo. De nada adianta aprofundar processos de ruptura, se não são desvendadas onde nascem as opressões e a exploração, algo que Darcy Ribeiro demonstra bem ao remontar o processo civilizatório.

Ao trilhar esse caminho, as feridas na construção da sociedade latinoamericana ficam mais expostas e assim passíveis de tratamento.

\begin{abstract}
Semanticamente a palavra "Modernidade" tem ambiguamente dois conteúdos: 1) Por seu conteúdo primário e positivo conceitual, a "modernidade" é emancipação racional. A emancipação como "saída" da imaturidade através de um esforço da razão como processo crítico, que abre a Humanidade a um novo desenvolvimento histórico do ser humano. 2) Mas, ao mesmo tempo, por seu conteúdo secundário e negativo mítico, a "modernidade" é justificação de uma práxis irracional de violência (DUSSEL, 1993, p. 185).
\end{abstract}

A modernidade hegemônica eurocêntrica inviabiliza importante ascensão da alteridade latino-americana. $O$ mito da modernidade permite vitimar 0 inocente declarando-o culpado por sua vitimação ${ }^{13}$. Assim, para 0

\footnotetext{
13 "La filosofía moderna eurocéntrica desde el ego conquiro (yo conquisto, protohistoria del ego cogito), situando a los otros pueblos, a las otras culturas, y con ello a sus mujeres y sus hijos,
} 
implemento do projeto modernizante advindo da Europa seria "justificável" o ato sacrificial das culturas e dos povos residentes no continente que foi denominado América ${ }^{14}$.

Dessa forma é estabelecido um novo padrão de poder mundial em que a América pode ser considerada a primeira identidade forjada com a modernidade. A formação da América permite que emerjam a colonialidade do poder, o eurocentrismo e um desenvolvimento mais arrojado do capitalismo. A própria identidade europeia constitui-se a partir da conquista da América $^{15} \mathrm{e}$ pela primeira vez pode-se tratar da configuração global de um sistemamundo $^{16}$. Contudo, um sistema-mundo que possui o centro do capitalismo emanando de parte do continente europeu, sendo assim, decisivo para a tomada de diferentes destinos, que delinearão o desenvolvimento da modernidade entre a Europa e os outros países do mundo.

Das várias identidades existentes no continente americano aymaras, quéchuas, tupinambás, guaranis, etc. concebeu-se uma identidade única, o índio. Sendo essa, uma nova identidade colonial negativa e arquitetada desde o aspecto racial. Já a modernidade em si e a racionalidade ficaram diretamente associadas à vivência e experiência europeia, distanciando-se do que era desenvolvido na América e considerado atrasado, folclórico, irracional e primitivo. O que não deve ser omitido é justamente, como já salientado, a forma que criaram esse padrão moderno e racional. Em primeiro lugar expropriaram o colonizado; depois reprimiram, o quanto puderam, seus padrões de conhecimento, a objetivação de sua subjetividade, tratando-os como pertencentes a uma subcultura, e por fim, forçaram que os colonizados

los dominó dentro de sus propias fronteras como cosas o útiles manipulables bajo el imperio de la razón instrumental” (DUSSEL, 2011, p. 18-19).

${ }^{14} \mathrm{~A}$ crítica à modernidade será mais aprofundada no Capítulo II, ponto 2.1.2.

15 "Uma região historicamente nova constituía-se como uma nova id-entidade geocultural: Europa, mais especificamente Europa Ocidental. Essa nova id-entidade geocultural emergia como a sede central do controle do mercado mundial" (QUIJANO, 2005, p. 109).

${ }^{16} \mathrm{O}$ conceito de sistema-mundo é desenvolvido, sobretudo, por Immanuel Wallerstein (1974), André Gunder Frank (1980), Giovanni Arrighi (1994) e Samir Amin (1997). Irá centrar-se no avanço do capitalismo mundial como força determinante entre os países centrais e periféricos, seu sistema social e inter-relações. 
aprendessem a cultura dos colonizadores e seu papel social. (QUIJANO, 2005, p. 111).

Assim, parte das propostas históricas de integração dos povos da América Latina consiste em mera forma de exercer a dominação através da imposição econômica e cultural da classe e raça dominante. A reação dos povos oprimidos, mais visível ultimamente, é atrelar as lutas étnicas à luta de classes, como ocorreu no início do século XXI na Bolívia e no Equador.

Desde o período colonial, a política de branqueamento foi uma das características da formação do Estado-nação e da própria criação de identidade nacional a partir da negação de outras etnias. Mesmo a mestiçagem, que se desenvolve em alguns países entre a elite criolla branca "civilizada" e os "índios selvagens", não apresenta uma proposta de construção nacional-popular a partir da conjunção das raças, mas desde uma perspectiva de branqueamento físico e cultural, de um povo que não era branco em sua maioria. O que se destaca é uma construção de uma mestiçagem que não suporta ver seu próprio reflexo, pois reproduzem a ilusão de superioridade do branco sem sê-lo, de fato, ao invés de resgatarem a rebeldia histórica indígena. Assim, um projeto verdadeiramente nacional torna-se inviabilizado em decorrência desse discurso de poder proveniente da construção mestiça, ligada à lógica da colonialidade do poder (QUIJANO, 2005).

O cenário político e histórico, pós-independência formal, dos Estados Latino-americanos criou um conjunto de violências culturais, epistêmicas, sociais, em que negava em certa medida, e desumanizava o negro, além de inferiorizar o índio, qualquer que fosse sua etnia, como seres ignorantes e submissos.

A construção do Estado e da sociedade evidencia-se sem a contribuição dos povos oprimidos formadores desses territórios e com uma intencional omissão dos conflitos e desigualdades existentes. No final do século $X X$, o máximo que a elite dominante permitia era, o que ficou conhecido como, multiculturalismo, onde se destacava um cenário de múltiplas culturas convivendo em uma mesma ordem capitalista (LINS RIBEIRO, 2005).

Atualmente, a luta travada pelos movimentos ligados aos povos indígenas e afrodescendentes extrapola a luta meramente étnica, mas pode ser 
acoplada a uma luta pela construção e ressignificação de uma sociedade nacional ${ }^{17}$.

Logo, dois eixos fundantes são estabelecidos, de acordo com Aníbal Quijano, para análise desse novo padrão de poder. Um é a codificação da diferença a partir de uma suposta distinção biológica das raças, situando uma inferioridade natural de uma para dominação da outra. Algo que antes não ocorria em relação às raças ou grupos e desenvolve-se com a conquista da América essa ideia. Formando assim identidades relacionadas a um sistema de dominação através de hierarquias e papéis sociais. O segundo eixo é o controle do trabalho em torno do capital e do mercado mundial (2005, p. 107). $A$ ideia de raça possui um papel central no trajeto dado à modernidade para a legitimação das relações de dominação e, consequentemente, ao próprio desenvolvimento capitalista, que é estruturado desde uma divisão racial do trabalho como uma forma de controle do mercado mundial.

Justamente, o fato dos mecanismos de controle dinamizados pelo capital, atrelados à ideia hierarquizada de raça, advinda na modernidade, que servirão para compor o que é denominado de colonialidade do poder. Esse elemento surge na própria formação dos Estados-nações da América Latina, conforme destacado no ponto anterior e não é eliminado, visto que não há um processo de democratização radical dos setores sociais estratégicos na sociedade e no próprio Estado, como acesso à terra, às riquezas, à informação adequada, dentre outros para a maior parte da população. Isso sim possibilitaria um processo de descolonização das relações sociais existentes a partir das raças formadoras do povo dos respectivos Estados latinoamericanos. Da mesma forma, expurgar a raça como forma universal de classificação social é uma maneira de descolonizar as relações de dominação existentes, não caracterizando o indígena, o negro ou o mestiço como inferiores ao branco. (QUIJANO, 2008. p. 108).

A colonialidade do poder, constituída a partir da ideia de raça como instrumento de dominação, associado à exploração do trabalhador, serve ao desenvolvimento do capitalismo mundial. A configuração de poder se dá a

\footnotetext{
17 "Así, la presencia de los pueblos afro e indígenas en la historia reciente, ha politizado la diferencia étnico-cultural-colonial, situándola no como problema étnico sino como problemática de la sociedad nacional." (WALSH, 2009a, p. 52).
} 
partir de um cenário de globalização. Mais do que um país, busca-se desenvolver um padrão de poder capitalista.

1.2.2. O imperialismo e a dependência latino-americana.

Os elementos trazidos até então, ajudam a observar a construção hegemônica do capitalismo convivendo com aspectos coloniais relacionados à ideia de raça, por exemplo, que estruturam o próprio capitalismo na parte sul do globo. Logo, essa mesma sociedade capitalista alcança um maior nível de desenvolvimento nas áreas onde foi possível uma maior democratização do mercado ${ }^{18}$ e uma modernização mais vigorosa do Estado-nação, ou seja, nos países de economia central, Estados Unidos e parte dos países europeus, em grande medida.

Toda democratização, por mais que não implique na destruição do capitalismo, contribui para a descolonização das relações de poder. Importante destacar esse ponto, que será desenvolvido em tópicos posteriores ${ }^{19}$, ao analisar a diversidade democrática, ora reconhecida, com a Constituição do Estado Plurinacional da Bolívia.

No entanto, o processo de globalização atual, atrelado ao modelo neoliberal, não provoca a democratização de setores da sociedade e do Estado. Ao contrário, hoje a burguesia financeira, que está à frente dos processos de manutenção do status quo social, precisa de um Estado menos democrático e nacional, possibilitando uma reconcentração do poder. (QUIJANO, 2000, p. 88). Certamente, os países de economia periférica, os quais o Estado-nação foi insuficientemente desenvolvido, em decorrência da colonialidade do poder, tendem a sofrer mais as consequências desse processo de reestruturação do padrão de poder capitalista. Assim, a

\footnotetext{
18 "El mercado interno en el período del capital competitivo fue no sólo un resultado de la actuación del capital, sino un resultado de los conflictos/negociaciones político-sociales". (QUIJANO, 2000, p. 84).

${ }^{19}$ Ver Capítulo 2
} 
exploração desses povos é mais intensa por alguns motivos que devem vir à baila. Boaventura de Sousa Santos, remetendo à Marx, destaca duas formas sequênciais que ocorrem a acumulação do capital na América Latina.

\begin{abstract}
Por un lado, la acumulación que resulta de la reproducción ampliada del capital y que, sin demasiado rigor, podemos considerar que opera por mecanismos económicos; por otro lado, la acumulación primitiva que, según Marx, precede a la acumulación ampliada y que consiste en la apropiación, casi siempre ilegal y violenta, y siempre con recurso a mecanismos extraeconómicos (políticos, coercitivos), de la tierra, de los recursos naturales y de la fuerza de trabajo necesarios para sostener la reproducción ampliada. Tales mecanismos han incluido históricamente el despojo colonial, la esclavitud, la coerción política, la violencia paramilitar, la ocupación extranjera para controlar los recursos naturales y las poblaciones, etc. (2010, p. 58).
\end{abstract}

Nesse cenário um dos elementos que não saem da ordem do dia, e deve ser tratado de forma séria, é o imperialismo. Sobretudo, sua forma de atuar na dinâmica do desenvolvimento capitalista. Para compreender o termo, sem usá-lo como um chavão vazio, entendendo seus significados e consequências na vida real, é fundamental revisitar o clássico escrito por Lenin em 1916 e publicado em 1917, Imperialismo, fase superior do capitalismo.

Praticamente todos os empreendimentos desenvolvidos na América Latina, mesmo após a independência dos países, já no século XIX, foram utilizados para oprimir os milhões que aqui viviam e potencializar os interesses comerciais das grandes nações internacionais ${ }^{20}$. A concentração de riqueza entre a burguesia dos países de economia central ${ }^{21}$ conduzia ao monopólio,

\footnotetext{
20 "A construção dos caminhos-de-ferro brasileiros realiza-se, na sua maior parte, com capitais franceses, belgas, britânicos e alemães; os referidos países, ao efetuarem-se as operações financeiras relacionadas com a construção de caminhos-de-ferro, reservam-se as encomendas de materiais de construção ferroviária. O capital financeiro estende assim as suas redes, no sentido literal da palavra, em todos os países do mundo. Neste aspecto desempenham um papel importante os bancos fundados nas colônias, bem como as suas sucursais." (LENIN, 1984).

${ }^{21}$ Ao tratar dos países de economia central refiro-me àqueles países que podem determinar-se quanto ao que produzir e a circulação dos seus bens. Recebe o legado da Revolução Industrial (tendo anterioridade de implementos tecnológicos), aumentando seu capital constante, acrescentando assim a mais-valia relativa. Aliás, passando da mais-valia absoluta à relativa. Onde os trabalhadores recebem, via de regra, melhores salários, os produtos possuem
} 
visto que era muito mais simples às empresas gigantes monopolistas, intermediadas pelos Estados, chegarem a acordos. Os bancos cumprem um papel central nessa dinâmica, visto que ativarão capital dinheiro-inativo, colocando-o a serviço da classe capitalista.

Essa movimentação dá início ao capitalismo financeiro, o qual faz girar, através dos bancos, o capital industrial, que não mais pertence tão somente aos industriais, além de iniciarem a atividade especulativa para lucrarem mais. Já em 1915, os Estados Unidos, a Alemanha, a Inglaterra e França detinham $80 \%$ do capital financeiro mundial. O resto dos países são devedores desses banqueiros internacionais (LENIN,1984).

Conforme já destacado, a necessidade da exportação de capitais obedece ao fato de que em alguns países, aqueles que compõem as economias centrais do sistema-mundo, o capitalismo amadureceu excessivamente e o capital carece de campo para a sua colocação lucrativa. Ademais, Hilferding (1985, p. 289) aponta que as tarifas protecionistas exerciam um papel fundamental, pois deixava em desvantagem a produção externa, viabilizando a produção interna. Contudo, nos países periféricos, o capital é escasso e a matéria-prima e a mão-de-obra mais baratos, assegurando lucros elevados aos países que lá forem investir (LENIN, 1984). Dessa forma, os investimentos cresciam na América Latina com o claro propósito de aumento da margem de lucro dos grandes centros econômicos. Uma vez estabelecida essa forma de relação de subordinação econômica, chegam-se aos marcos da divisão internacional do trabalho ${ }^{22}$ entre os países do globo. Antonio Gramsci chama a atenção para os efeitos dessa divisão, em que “(...) a riqueza nacional está condicionada pela divisão internacional do

menores preços (por conta da circulação de produto interno e necessita de menor tempo para conceber uma unidade do produto). Assim, tem o potencial de criar o mercado mundial e indicar o lugar de cada capital na divisão internacional do trabalho. (DUSSEL, 1991, p. 385).

\footnotetext{
22 "É a partir desse momento que as relações da América Latina com os centros capitalistas europeus se inserem em uma estrutura definida: a divisão internacional do trabalho, que determinará o sentido do desenvolvimento posterior na região. Em outros termos, é a partir de então que se configura a dependência, entendida como uma relação de subordinação entre nações formalmente independentes, em cujo marco as relações de produção das nações subordinadas são modificadas ou recriadas para assegurar a reprodução ampliada da dependência." (MARINI, 2005, p. 141).
} 
trabalho e por saber eleger entre as possibilidades que essa divisão oferece, a mais racional e rentável para cada país dado." (Tradução livre) (1999, p. 370).

No momento de configuração dessa relação de subordinação e criação de dependência, que o imperialismo mostra sua força, com o propósito de controlar as relações estabelecidas mundialmente, sejam elas econômicas ou políticas. O imperialismo serve como uma forma de pressionar para o maior cumprimento possível da acumulação primitiva ${ }^{23}$ na América Latina e, consequente, controle dos recursos naturais. $\mathrm{O}$ que ainda não foi dominado, 0 imperialismo tratará de efetivar a dominação quando conjunturalmente possível (LENIN, 1984).

A dependência criada na América Latina vai além das questões coloniais, configurando-se um problema próprio, a partir da organização capitalista no sistema-mundo. Ao longo do século $X X$, algumas nações subordinadas passam a produzir, tão só, reproduzindo uma lógica ampliada de dependência.

Esse será um problema central para os países latino-americanos. Pois, há uma mudança de eixo nos países de economia central. Eles passam a priorizar a produção de mais-valia relativa em seus respectivos territórios e não mais a mais-valia absoluta. Ou seja, a acumulação passa a depender mais do aumento da capacidade produtiva do trabalho, como na utilização de máquinas, do que simplesmente da exploração do trabalhador, como no aumento de jornada. (MARINI, 2005, p. 144).

Essa mudança de perspectiva é possível, visto que, os países de economia central no sistema mundo, possuem um processo de acúmulo capitalista mais integrado e com isso tem um maior acesso ao desenvolvimento tecnológico. Além de cumprirem um papel de ponta na divisão internacional do trabalho, exportando produtos de alta tecnologia, diferentemente dos países latino-americanos. Esses, conforme imposto desde a conquista, priorizam a venda de produtos primários como commodities minerais e agrícolas, a preços mais baratos, diminuindo o valor que os países de economias centrais

\footnotetext{
${ }^{23}$ Os autores da teoria da dependência, em regra, não trazem o debate da acumulação primitiva do capital para a América Latina. Talvez em uma problematização se, de fato, ela ainda ocorria no século XIX.
} 
perderiam ao adquirirem esse capital constante ${ }^{24}$, indispensável à sua produção, permitindo o aumento da taxa de lucro desses últimos (MARINI, 2005).

O que irá ocorrer em decorrência dessas relações é a troca desigual entre nações. Umas produzem bens que as outras não produzem ou tem dificuldade de fazer. Logo, vendem por preço superior os bens. As nações desfavorecidas ou capitalistas periféricos, ao invés de tentarem corrigir a desigualdade equilibrando preços e o valor das mercadorias, investindo no aumento da capacidade produtiva do trabalho, por exemplo, buscam compensar a perda gerada internacionalmente através de maior exploração do trabalhador/a. (MARINI, 2005, p. 153). Assim, o cenário internacional apresenta uma menor exploração dos trabalhadores/as em países da Europa e Estados Unidos e um quadro de maior exploração dos trabalhadores/as latinoamericanos, não só para garantir o ganho dos países de economia central, mas, sobretudo, para conter a queda da taxa de lucro da burguesia local, por meio do intercâmbio desigual.

Toda essa movimentação permite o desenvolvimento das forças produtivas dos países centrais, a partir da superexploração dos trabalhadores/as dos países de economia periférica ${ }^{25}$, ou seja, um caráter contraditório da dependência.

Para Ruy Mauro Marini, um dos grandes intelectuais orgânicos da teoria da dependência, a superexploração ocorria a partir de três mecanismos fundamentais para caracterizar a dependência que os países latino-americanos sofrem.

\footnotetext{
${ }^{24}$ Capital constante será "a massa de valor dos meios de produção empregados". (MARX, 1996, p. 326).

${ }^{25}$ Ao referir aos países de economia periférica trato o conceito a partir da ideia de Enrique Dussel. O capital periférico sofre determinação externa no processo produtivo, do que produzirá e no preço (ex: commodities, a partir da conveniência das economias centrais; produtos industrializados, pagando mais trabalho objetivado). Algumas nações de capital periférico recebem o legado da revolução industrial dois séculos depois que as nações de economia central. Assim, prolongam a obtenção de mais-valia absoluta. (Devido uma maior distância para a circulação dos produtos que agregam mais valor por serem produzidos nas economias centrais, maior é o preço ao chegarem aos países periféricos por conta da importação-exportação). Os salários são menores, via de regra, e o mercado interno fraco. (DUSSEL, 1991, p. 385).
} 
Pois bem, os três mecanismos identificados - a intensificação do trabalho, a prolongação da jornada de trabalho e a expropriação de parte do trabalho necessário ao operário para repor sua força de trabalho - configuram um modo de produção fundado exclusivamente na maior exploração do trabalhador, e não no desenvolvimento das suas forças produtivas na economia latino-americana, mas também com os tipos de atividades que ali se realizam (MARINI, 2005, p. 156).

A dependência demonstra a dominação do capital central frente ao capital periférico, desenvolvido pelos países da América Latina com variações específicas a depender do Estado, mas mantendo a essência. Além disso, não pode ser descartado o papel fundamental que a elite interna também possui para a manutenção desses mecanismos reprodutores da dependência. Pois, esta mesma dependência configura-se desde uma perspectiva relacional, e não eminentemente externa.

Mais recentemente, pode se falar de uma transnacionalização ${ }^{26}$ do centro. O capital transnacional ao qual nos referimos, é uma parte do capital mundial. Na verdade é o capital das economias centrais que supera o horizonte produtivo da nação. (DUSSEL, 1991, p. 388). Interfere no espaço produtivo das economias periféricas com maior composição orgânica, já que possui tecnologia agregada e gasta menos com mão-de-obra. Aumenta assim sua taxa de mais-valia e lucro. Isso configura um momento ampliado da dependência, não sua negação! (DUSSEL, 1991, p. 389).

O capital central busca superar o processo desvalorativo do próprio capital, devido à dificuldade de aumentar a mais-valiaa ${ }^{27}$, desde a subordinação do capital periférico a partir da dependência. Assim, o capital central necessita de outro capital, o periférico, para realizar-se. As elites dominantes tendem, porque precisam disso para a manutenção do poder, a manter e aprofundar quando possível, a dependência dos países latino-americanos.

O ano de 2013 foi mais um ano comemorativo para o capital transnacional atuante na América Latina, em contrapartida ao

\footnotetext{
${ }^{26}$ Trata-se do estabelecimento de uma dinâmica transnacional do capital monopolista.

${ }^{27}$ Já que a sua composição orgânica é alta, em decorrência do capital constante.
} 
cenário de acirramento da precarização e intensificação da superexploração da força de trabalho na região (TRASPADINI, $2014)^{28}$.

A dependência é um problema que deve ser superado por qualquer país latino-americano que pretenda ser, de fato, soberano. Para isso será fundamental enfrentar a força do imperialismo, que não permitirá a perda de controle, necessária ao desenvolvimento do seu capital, conforme demonstrado na sua própria razão de existência. Além da elite interna, que convenientemente mantêm a lógica da dependência atrelada aos ranços coloniais históricos, que os mantêm em condições pseudo-aristocráticas e privilegiadas frente ao povo.

$\mathrm{Na}$ atualidade, é necessário captar o funcionamento dos processos de globalização, os quais enraízam a articulação e a influência recíproca de três grandes formações sociais na organização da economia mundial: seja a partir do capitalismo central de hegemonia anglo-saxã, o capitalismo dependente e o socialismo de mercado ou capitalismo de Estado, em decorrência da projeção chinesa no cenário econômico mundial. Além de analisar as transformações políticas nos diversos países da América Latina, a crise de hegemonia neoliberal, o pós-neoliberalismo e as inúmeras formas de desenvolvimento a que dá lugar, a conexão desta "região com a dinâmica de crescimento chinesa e suas perspectivas de curto, médio e longo prazo, bem como os riscos de desindustrialização e reprimarização da pauta exportadora da América Latina". A possibilidade de ruptura com o modelo dependente passa por ações políticoeconômicas que estão atentas a esses pontos e dispostas a modificar sua estrutura produtiva. (MARTINS, 2013, p. 44).

Essa luta não logrará êxito se realizada de maneira isolada. Outros países devem agregar essa bandeira anti-imperialista e através de um bloco

\footnotetext{
28 "A América Latina possui uma população aproximada de 610 milhões de pessoas, segundo a CEPAL. (...) Destas 164 milhões se encontram em situação de pobreza e 68 milhões em pobreza extrema. Entendida a pobreza como um processo histórico-social, resultado do modelo de desenvolvimento capitalista consolidado no continente nos últimos seis séculos, cujo pressuposto é o pagamento de salários abaixo da condição de sobrevivência cotidiana." (TRASPADINI, 2014).
} 
em unidade, fazer esse enfrentamento frente à dependência histórica vigente na América Latina, se realmente buscam esse objetivo.

1.2.3. A ideia de partido, o bloco histórico e a hegemonia diante da realidade dos Estados do Sul.

O contexto apresentado no trabalho demonstra a importância da construção de força política coesa para enfrentar os desafios grandiosos que implica a construção de um projeto popular que ousa transformar as vidas dos povos latino-americanos.

Alguns instrumentos foram concebidos para possibilitar a organização de pessoas em torno dessa proposta transformadora, tal como apontam Lenin e Antonio Gramsci. Ao trazer esses dois teóricos e militantes marxistas como referenciais para a análise desses instrumentos, e mais a frente, apreciação da realidade boliviana, estar-se-á apontando para a importância da mudança desde uma perspectiva revolucionária. Além do mais, a partir da influência desses autores e o desenvolvimento de suas categorias, abre-se a possibilidade de análise de outros referenciais que aprofundaram e moldaram essa linha de pensamento marxista desde a situação da realidade boliviana como Rene Zavaleta Mercado, Álvaro Garcia Linera e outros/as, os quais serão abordados com mais vagar nos próximos tópicos.

Nesse ambiente de mudanças na América Latina, observa-se que o partido, como instrumento organizativo de mudança social, quando inserido na dinâmica da democracia representativa, contribuiu muito pouco para as alterações de projeto político, que então vigiam. No entanto, o significado do partido não pode ser usado somente dessa forma, limitada à atuação sistêmica.

São três seus grandes objetivos: a organização política das pessoas, unificar as lutas populares e a formação política (LENIN, 2010). Por meio desses elementos, mesmo organizações políticas que não disputavam eleição, nem se autodenominavam partido, tinham uma forma de se portar como tal, e 
foram fundamentais para processos transformadores no continente americano. Exemplos não faltam como: o Movimento 26 de Julho em Cuba, a Frente Sandinista de Libertação Nacional na Nicarágua, entre outras tantas. Não há experiência revolucionária espontaneísta que tenha vingado. Sempre prescindiu-se de uma vanguarda compartilhada, construída a partir de anseios genuinamente populares e amparada por uma organização política.

Assim, a ideia de partido, para além da lógica eleitoral, possibilitará a ação organizada de um coletivo e permitirá a metassíntese de teoria e prática do processo histórico real, como aponta o italiano Antonio Gramsci. É fundamental "a importância e o significado que têm os partidos políticos, no mundo moderno, na elaboração e difusão das concepções do mundo, na medida em que elaboram essencialmente a ética e a política adequadas" (GRAMSCI,1995, p. 22).

Inúmeras vezes, as movimentações dos partidos para as mudanças necessárias ao Estado são insuficientes e limitadas, conforme, já salientado. Sobretudo, quando esses partidos atuam somente em uma lógica institucional, dentro de Estados débeis econômica, político e militarmente. O papel combativo fica a cargo dos movimentos sociais e outros tipos de organização da sociedade civil.

Assim, via de regra, esses atores tornam-se responsáveis por reivindicações que sequer tratam de rupturas, mas, no máximo, reformas para que o Estado possa garantir mais direitos e melhores condições de vida ao povo. Ou seja, os partidos, dentro da estrutura liberal de Estado, tem o potencial de cobrar e direcionar seus mandatos a uma maior atuação desse Estado em prol da população para assegurar direitos, como um maior acesso à cultura, educação, saúde, lazer, emprego, etc. Os países latino-americanos, em geral, padecem desses vários direitos, estando os Estados reféns das políticas imperialistas e, consequentemente, de um capitalismo dependente, suportado também pela elite local, como já destacado. Observa-se o Estado cumprindo um papel central ${ }^{29}$ na vida do povo e na própria possibilidade de

${ }^{29}$ Em determinados momentos históricos e devido a própria fragilidade de alguns países, o Estado é pressionado a conceder maiores garantias, mesmo entendendo desde o ponto de vista marxista, que ele é caracterizado ontologicamente por ser um órgão de dominação, que consolida essa submissão, amortecendo a colisão das classes. (LENIN, 2007). 
transformá-la, devendo em certos períodos históricos, reforçar suas bases, como afirma Gramsci.

Para alguns grupos sociais que, antes da tomada do poder, não viveram um longo período de desenvolvimento cultural e moral independente (como se tornava possível na sociedade medieval e nos Estados absolutos, por exigência jurídica dos Estados e ordens privilegiadas), um período de estadolatria é mesmo oportuno. (GRAMSCI apud PORTELLI, 1977, p. 44).

Embora, Gramsci ao afirmar isso, use um tom evolutivo eurocêntrico, e até certo ponto inadequado, ele chama a atenção para a importância do Estado como instrumento fundamental para as rupturas ocorrerem em uma sociedade capitalista, onde as forças produtivas foram pouco desenvolvidas.

O Estado assume centralidade como instrumento de poder. Com isso, fica claro que a tomada do Estado é basilar ${ }^{30}$, para que as classes subalternas consigam unificar as demandas da sociedade civil com os mecanismos da sociedade política ${ }^{31}$ para avançar hegemonicamente com um novo projeto político. Quando a classe, a sociedade civil e esse Estado, em sentido estrito, convergem nas linhas centrais do projeto posto, a hegemonia estará consolidada. Para Karl Marx essa é a situação em que se vislumbra na "estrutura econômica da sociedade, a base real sobre a qual se levanta uma superestrutura jurídica e política, e à qual correspondem formas sociais determinadas de consciência" (1978, p. 129-130).

Em alguns de seus clássicos ${ }^{32}$, Marx consegue explicitar justamente essa possibilidade de autonomia relativa do aparelho de Estado, instrumento

\footnotetext{
30 "La unidad histórica fundamental, por su concreción, es el resultado de las relaciones orgánicas entre Estado o sociedad política y "sociedad civil". Las clases subalternas, por definición, no están unificadas y no pueden unificarse mientras no puedan convertirse en "Estado" (GRAMSCI, 2000, p. 182).

${ }^{31}$ Termo gramsciano também usado como o Estado em sentido estrito, ou seja, instrumentos de funcionamento do comando, da burocracia e coerção do Estado.

${ }^{32}$ Cf. MARX, Karl. 018 Brumário de Luís Bonaparte. Trad. Nélio Schneider. São Paulo: Boitempo editorial, 2011; MARX, Karl. A Guerra Civil na França. Trad. Ruben Enderle. São Paulo: Boitempo editorial, 2011; MARX, Karl. As lutas de classe na França de 1848 a 1852. Trad. Nélio Schneider. São Paulo: Boitempo editorial, 2012a.
} 
ontológico da burguesia, como resultado da dinâmica da luta de classes presente no modo de produção capitalista.

Nenhuma classe isoladamente terá os seus interesses correspondidos, de forma integral, ao longo do exercício político das instituições do Estado. Contudo, aquela classe ou grupo que possuir a hegemonia ${ }^{33}$ terá condições, dentro do processo conflitivo social, de manter ou até ampliar mais facilmente sua posição dominante ${ }^{34}$, reforçando as alianças necessárias ao bloco histórico que lhe assegura poder e fazendo com que seus interesses sejam vistos como a metassíntese da vontade nacional e interesse geral do povo.

A teorização sobre a hegemonia é fundante para uma teoria da organização. A hegemonia deve ser formulada desde as classes fundamentais que compõem a luta social. Portelli salienta os pontos de debate sobre 0 conceito de hegemonia entre Lenin e Gramsci para uma abordagem mais refinada da categoria.

O conceito gramsciano de hegemonia está, pois, bastante próximo do de Lenin. Entretanto, ambos divergem em um ponto capital. A preeminência da direção cultural e ideológica. Lenin, em seus escritos sobre a hegemonia, insiste sobre seu aspecto puramente político; o problema essencial para ele é a derrubada, pela violência, do aparelho de Estado. [...] E com maior razão na medida em que, como vimos, a sociedade civil é muito débil na Rússia. Gramsci, ao contrário, situa o terreno essencial da luta contra a classe dirigente na sociedade civil. $(1977$, p. 78)

Esse debate de hegemonia na América Latina passa justamente pela análise a respeito da possibilidade das classes subalternas, angariados por um bloco histórico, terem força política suficiente para derrubarem um Estado frágil

33 "El hecho de la hegemonía presupone indudablemente que se tomen en cuenta los intereses y las tendencias de los grupos sobre los cuales la hegemonía será ejercida, que se forme un cierto equilibrio de compromiso, esto es, que el grupo dirigente haga sacrificios de orden económico-corporativo, pero también es indudable que tales sacrificios y tal compromiso no pueden afectar a lo esencial, porque si la hegemonía es ético-política, no puede dejar de ser también económica, no puede dejar de tener su fundamento en la función decisiva que el grupo dirigente ejerce en el núcleo decisivo de la actividad económica." (GRAMSCI, 1999, p. 42).

34 "El ejercicio "normal" de la hegemonía en el terreno que ya se ha vuelto clásico del régimen parlamentario, se caracteriza por la combinación de la fuerza y del consenso que se equilibran diversamente, sin que la fuerza domine demasiado al consenso, incluso tratando de obtener que la fuerza parezca apoyada en el consenso de la mayoría". (GRAMSCI, 1999, p. 81). 
em uma sociedade civil desorganizada, como ocorreu na Revolução Cubana, ou constituir hegemonia na sociedade civil a ponto de derrubarem a classe dirigente do comando da sociedade política para, então, refundarem ${ }^{35} 0$ Estado.

O desafio dos dirigentes das classes subalternas, ao conseguirem hegemonizar um projeto político popular em seus respectivos países, é o de manter essas mudanças incluindo os dirigidos para efetivar essa proposta de transformação. Favorecendo o ambiente verdadeiramente democrático desde que preservado os compromissos libertários de ruptura da nova perspectiva hegemônica.

Entre tantos significados de democracia, el más realista y concreto me parece que se puede extraer en conexión con el concepto de hegemonía. En el sistema hegemónico, existe democracia entre el grupo dirigente y los grupos dirigidos, en la medida en que [el desarrollo de la economía y por lo tanto] la legislación [que expresa tal desarrollo] favorece el paso [molecular] de los grupos dirigidos al grupo dirigente. (GRAMSCl, 1984, p. 313).

Contudo, isso somente será possível com a configuração coesa de um bloco histórico. Essa será uma categoria fundamental para a análise do processo transformador na Bolívia, como veremos.

A formação desse bloco histórico subalterno é essencial, em um primeiro momento, para derrubar o bloco histórico dominante. Qualquer força política popular, isoladamente, terá extrema dificuldade de desmantelar as forças políticas dirigentes, que além do poder econômico detêm os instrumentos de coerção do Estado nas mãos. A partir do momento em que se configura a crise orgânica, representada pela ruptura da estrutura e superestrutura, agravam-se as contradições. Assim, o bloco histórico dominante não terá mais legitimidade para dirigir aquela sociedade e o novo

\footnotetext{
${ }^{35}$ Refundação essa, onde a sociedade política será absorvida pela sociedade civil na nova composição do Estado, de acordo com o pensamento gramsciano.
} 
bloco histórico deve estar preparado para apresentar um novo projeto ${ }^{36}$ e tomar os instrumentos da superestrutura, concebendo uma nova hegemonia.

Esse momento inicial de tomada do poder requer alianças táticas para acúmulo de força direcionado a uma estratégia maior e transformadora. Só assim, o novo bloco histórico terá êxito inicial para legitimar-se perante a sociedade, conforme alerta Gramsci.

(...) esto es para cambiar la dirección política de ciertas fuerzas que es necesario absorber para realizar un nuevo bloque histórico económico-político homogéneo, sin contradicciones internas, y puesto que dos fuerzas "similares" no pueden fundirse en uno nuevo organismo más que a través de una serie de compromisos o por la fuerza de las armas, aliándolas en un plan de alianza, subordinando la una a la otra por la coacción, la cuestión es si se tiene esta fuerza y si es :"productivo" emplearla. Si la unión de dos fuerzas es necesaria para vencer a una tercera, el recurso a las armas y a la coacción (dado que se tenga la disponibilidad) es una pura hipótesis metodológica y la única posibilidad concreta es el compromiso, porque la fuerza puede ser empleada contra los enemigos, no contra una parte de uno mismo que se quiere asimilar rápidamente y de la que se necesita la "buena voluntad" y el entusiasmo. (1999, p. 60)

Gramsci chama a atenção para a importância em derrotar o inimigo maior em um primeiro momento, ou seja, com a ascensão de um novo bloco histórico popular é fundamental atacar o bloco histórico dirigente, o qual provavelmente estará aliado com as força imperialistas, para depois readequar a linha política. A disputa intrabloco, entre correntes progressistas divergentes, antes da batalha contra o bloco dirigente, tende a transformar uma possível vitória das classes populares em uma derrota retumbante.

A postura fundamental para o êxito do bloco histórico é a unidade, a organização e a disposição de luta das massas, a partir da situação política concreta. A luta popular trará a liga que conceberá esse bloco a partir dos

\footnotetext{
36 "Puede y debe existir una "hegemonía política" incluso antes de llegar al gobierno y no hay que contar sólo con el poder y la fuerza material que éste da para ejercer la dirección o hegemonía política." (GRAMSCI, 1981a, p. 107).
} 
princípios dos grupos e dos compromissos traçados nessa aliança que forjará o novo bloco histórico.

A contribuição de Lenin, na análise do papel do partido, e Gramsci na configuração da hegemonia e na formação do bloco histórico é fundamental quando se almeja refletir as transformações necessárias às alterações do modo de produção estabelecido e a linha político-ideológica vigente. No entanto, a mera aplicação automática das categorias desenvolvida por ambos, em suas respectivas práxis políticas, devem ser utilizadas levando em consideração o momento histórico e o contexto político concreto de sua reflexão/aplicação.

Logo, não é o caso, reproduzi-las abstrata e idealmente, negando o próprio materialismo histórico dialético que está embutido em seu método de aplicação. Lenin desenvolve seu processo de reflexão a partir da teoria marxista, em função de sociedades pré-capitalistas, frágeis à organização da sociedade civil como era a Rússia czarista. Daí a grande importância dada ao Estado, à ditadura do proletariado, ao aspecto militar e ao centralismo do partido. Certamente todas essas categorias são úteis aos processos de ruptura que ainda não foram realizados.

No entanto, hoje, tratando de América Latina, o foco também deve ser dado à sociedade civil. Essa, uma vez organizada em um bloco histórico, tem condições de construir hegemonia através da luta política e tomar o aparelho do Estado. Até certo ponto, já é possível visualizar a construção de um novo sistema hegemônico atuando mais na esfera da sociedade civil que propriamente no Estado, em sentido estrito. Esses processos podem possibilitar a refundação de um Estado de novo tipo, em que de acordo com as categorias gramscianas, a sociedade política passa a ser reabsorvida pela sociedade civil. Essas mudanças fazem parte de processos de ruptura e lutas que não ocorrem de uma hora para a outra, sobretudo em realidades como a latino-americana, em que as estruturas coloniais de poder e dependência capitalista profunda estão vigorando. Contudo, não há como negar que, em alguns Estados latino-americanos, esses processos transformadores já se iniciaram. 


\subsection{O ator coletivo da hiperpotentia como desencadeador da práxis libertadora na realidade latino-americana}

A hiperpotentia é forjada a partir de desconstruções e crises antihegemônicas que possibilitam a construção de novas hegemonias. Este cenário configura-se em momentos em que o sistema institucional político, ainda hegemônico, é insuficiente para dar respostas e criar legitimidade em sua atuação (LEONEL JÚNIOR, 2013a). O povo insatisfeito com as práticas vigentes toma consciência e reivindica novos direitos.

Neste contexto, a classe dirigente, de hegemônica, perde seu poder ideologizador daquela realidade social e passa a ser só dominante, conforme já destacado no tópico anterior. Esta mera dominação é resultado desta crise de legitimidade, onde o Estado recorre à violência para manter o domínio e a prevalência de seus interesses. Assim a potestas, ${ }^{37}$ fetichizada por um exercício despótico do poder, perde o suporte do povo, a potentia ${ }^{38}$. Daí falar na práxis libertadora concebida por Dussel, a partir da vontade e da força do povo oprimido.

Esta práxis, pensada a partir de um ator coletivo histórico, será responsável pela reformulação dos novos direitos provenientes dos clamores populares confrontando uma nova legitimidade surgida das lutas sociais frente à antiga legitimidade institucionalizada pelas classes dominantes. A confrontação ocorrerá e a violência institucional e ilegítima encontrará resistência na força popular, que a partir da construção de nova legitimidade

\footnotetext{
${ }^{37}$ Já citada institucionalização do poder do povo. "A necessária institucionalização do poder da comunidade, do povo (...)" (DUSSEL, 2007, p. 32).

38 "(...) poder que tem a comunidade como uma faculdade ou capacidade que é inerente a um povo enquanto última instância da soberania, da autoridade, da governabilidade, do político." (DUSSEL, 2007, p. 29).
} 
poderá combater as forças repressoras com os meios que se fizerem necessários à libertação do povo diante do julgo agressor dos opressores ${ }^{39}$.

Assim, a práxis libertadora é realizada pela hiperpotentia, que através do acúmulo de força e construção de unidade, deverá transformar a potestas em instituição direcionada ao povo.

Se a potentia [...] é uma capacidade da comunidade política, agora dominante, que organizou a potestas [...] em favor de seus interesses e contra o povo emergente, a hiperpotentia é o poder do povo, a soberania e autoridade do povo (que A. Negri simplesmente elimina em vez de localizá-lo em seu justo lugar) que emerge nos momentos criadores da história para inaugurar grandes transformações ou revoluções radicais. (DUSSEL, 2007, p. 100).

No entanto, ao considerarmos a importância da hiperpotentia e de seu papel transformador na sociedade, devemos dar uma cara a esse povo. Não será qualquer setor da sociedade que terá interesse em transformá-la ou, até mesmo, revolucioná-la. Nem o que concebemos como o povo oprimido, protagonista da hiperpotentia, deve ser visto como um conceito homogêneo que considerará os mesmos sujeitos de qualquer forma e local de atuação.

O sujeito revolucionário europeu, refletido pelos marxistas daquele continente, difere em determinados aspectos do ator coletivo da hiperpotentia latino-americana.

O procedimento usual dos estudiosos é projetar sobre a realidade latino-americana a tipologia das classes sociais correspondentes à Europa do século passado, atribuindo validez universal àqueles esquemas. Fala-se, assim, de burguesia, pequena burguesia, proletariado, campesinato e até

\footnotetext{
39 "A luta de classes se desenvolve historicamente com um coeficiente maior ou menor de violência, mas a experiência histórica demonstra que quando a existência da classe dominante se encontra em perigo, esta não vacila em recorrer às formas violentas mais extremas, inclusive 0 terror maciço, pois nenhuma classe social está disposta a abandonar voluntariamente o cenário da história." (VAZQUEZ, 2007, p. 377).
} 
lumpemproletariado para referir segmentos sociais concretos que com esses só guardam ligeiras semelhanças. Dessa forma se esconde ao invés de evidenciar as características reais da estrutura de classes das sociedades latino-americanas e se induz à expectativa de que certas categorias venham a representar aqui o papel histórico que seus símiles tiveram alhures. (RIBEIRO, 1983a, p.65.).

Mesmo que existam semelhanças consideráveis na utilização de algumas categorias devido à lógica expansiva do capitalismo, os sujeitos se diferenciarão em alguns aspectos e situações vivenciadas nas relações sociais e de produção na América Latina.

Logo, o conceito de povo, que Dussel trabalha, vem da definição de Fidel Castro, deve ter "face", ser concreto ${ }^{40}$. Não algo relativizado, sem constância ou análise rigorosa. Para isso, outro latino-americano deve ser revisitado, José Carlos Mariátegui. O pensador peruano não considerava o marxismo como uma filosofia da história para todo o tempo e lugar, visto de maneira dogmática. O marxismo é para ele um método de análise, não um conhecimento a priori. Assim, ele busca formular e aplicar esse método a partir da realidade latino-americana, sobretudo, a peruana.

\footnotetext{
40 "Nosotros llamamos pueblo si de lucha se trata, a los seiscientos mil cubanos que están sin trabajo deseando ganarse el pan honradamente sin tener que emigrar de su patria en busca de sustento; a los quinientos mil obreros del campo que habitan en los bohíos miserables, que trabajan cuatro meses al año y pasan hambre el resto compartiendo con sus hijos la miseria, que no tienen una pulgada de tierra para sembrar y cuya existencia debiera mover más a compasión si no hubiera tantos corazones de piedra; a los cuatrocientos mil obreros industriales y braceros cuyos retiros, todos, están desfalcados, cuyas conquistas les están arrebatando, cuyas viviendas son las infernales habitaciones de las cuarterías, cuyos salarios pasan de las manos del patrón a las del garrotero, cuyo futuro es la rebaja y el despido, cuya vida es el trabajo perenne y cuyo descanso es la tumba; a los cien mil agricultores pequeños, que viven y mueren trabajando una tierra que no es suya, contemplándola siempre tristemente como Moisés a la tierra prometida, para morirse sin llegar a poseerla, que tienen que pagar por sus parcelas como siervos feudales una parte de sus productos, que no pueden amarla, ni mejorarla, ni embellecerla, plantar un cedro o un naranjo porque ignoran el día que vendrá un alguacil con la guardia rural a decirles que tienen que irse; a los treinta mil maestros y profesores tan abnegados, sacrificados y necesarios al destino mejor de las futuras generaciones y que tan mal se les trata y se les paga; a los veinte mil pequeños comerciantes abrumados de deudas, arruinados por la crisis y rematados por una plaga de funcionarios filibusteros y venales; a los diez mil profesionales jóvenes: médicos, ingenieros, abogados, veterinarios, pedagogos, dentistas, farmacéuticos, periodistas, pintores, escultores, etcétera, que salen de las aulas con sus títulos deseosos de lucha y llenos de esperanza para encontrarse en un callejón sin salida, cerradas todas las puertas, sordas al clamor y a la súplica" (CASTRO, 2007, p. 33-34).
} 
Mariátegui cree (y lo dice) que una epistemología materialista es capaz de generar valores espirituales, lo cual es distinto y diametralmente opuesto, a hacer de la materia una religión (como de hecho fue el caso de marxismo vulgar). [...] No creía en una visión lineal de la historia, ni en aquello de que todos los pueblos debían pasar por las mismas etapas evolutivas, ni en leyes universales aplicables de manera indiscriminada y sin matices [...] Él planteo en medio del positivismo, del mecanismo newtoniano, del darwinismo social, una visión de América desde la perspectiva del dominado y no del dominador. Recordemos por un instante que el marxismo parte desde la perspectiva metropolitana del Manifiesto y de su modelo clásico (la sociedad inglesa), recordemos que es tributario de todo el pensamiento moderno y, por tanto, hace propio sus sueños y desvelos y también sus defectos. (MAGDALENA, 2008, p. 28).

A crítica ao marxismo dogmático eurocêntrico era necessária, pois esse não servia à realidade aplicável pelo amauta ${ }^{41}$, inclusive os sujeitos que potencializariam uma perspectiva transformadora na América Latina. Ao pensar o ator coletivo revolucionário, o sujeito indígena, por exemplo, deve estar inserido na análise, sobretudo, ao considerar países como a Bolívia, o Peru, o Equador, a Guatemala, em que se trata de grande parte da população.

Conforme, se depreende no pensamento de Mariátegui, é necessário dar a luta indígena um caráter de luta de classes. Observa-se isso ao constatar que não é meramente cultural o contexto da luta, mas também econômico. Partindo do próprio regime de propriedade das terras instituído pelas Metrópoles desde a época da colonização. Ao escrever o prólogo do livro Tempestad em Los Andes, de Luís Varcárcel, Mariátegui demonstra a importância do indígena na perspectiva de construção de uma sociedade socialista na América Latina.

No es la civilización, no es el alfabeto del blanco, lo que levanta el alma del indio. Es el mito, es la idea de la revolución socialista. La esperanza indígena es absolutamente

\footnotetext{
${ }^{41}$ Palavra quéchua que significa sábio, e tornou-se a alcunha do próprio Mariátegui.
} 
revolucionaria. El mismo mito, la misma idea, son agentes decisivos del despertar de otros viejos pueblos, de otras viejas razas en colapso: hindús, chinos, etc. [...] El socialismo nos ha enseñado a plantear el problema indígena en nuevos términos. Hemos dejado de considerarlo abstractamente como problema étnico o moral para reconocerlo concretamente como problema social, económico y político. Y entonces, lo hemos sentido, por primera vez, esclarecido y demarcado (VALACÁRCEL, 2000).

A motivação de uma sociedade livre das amarras do capitalismo é própria do comportamento e da vivência indígena, destacada ao deparar-se com o explorador, por isso Mariátegui ressalta seus anseios como revolucionários. Podemos considerar revolucionários, uma vez que a reprodução social e cultural indígena, originalmente parte de outras premissas sistêmicas institucionais, distintas das atuais dominantes, eurocêntricas e capitalistas. Diante da própria dinâmica de conquista da América Latina pelos países Europeus foram interrompidos processos autônomos inerentes aos diferentes povos habitantes dessas terras, como os Guaranis, os Quéchuas, os Aymaras, os Kaigangs, os Tupinambás, os Pataxós, os Maxacalis, etc.

Na obra clássica "Sete ensaios de interpretação da realidade peruana" Mariátegui explicita o fato de o problema indígena ligar-se diretamente as questões econômicas e sociais, a partir do regime de terras, conforme já pontuado. Assim, os próprios índios devem levar esta luta adiante. Deixando claro ainda, a importância de estarem organizados, de alguma forma para alcançarem seus objetivos, pois "enquanto não sejam mais que uma massa orgânica, uma multidão dispersa, são incapazes de decidir seu rumo histórico" (2008b, p. 65). Para isso, o peruano acreditava na importância de um partido organizador dos trabalhadores, não considerando necessariamente só 0 proletariado industrial, mas o expropriado, o excluído que se encontra na base da pirâmide da sociedade capitalista ${ }^{42}$.

\footnotetext{
42 "En definitiva Mariátegui planteaba un partido del proletariado, en el sentido que Marx le daba al término: no como sinónimo de obrero industrial, sino como sinónimo de desposeído, de expropiado, de excluido, de base de la pirámide de la sociedad capitalista fundada, precisamente, en su explotación." (MAGDALENA, 2008, p. 26-27).
} 
Em países como Bolívia e Peru, a grande massa dos povos indígenas são responsáveis, inclusive, pela força de trabalho de parte da própria economia capitalista, seja no trabalho agrícola, no minerador ou no industrial. Logo, de acordo com Mariátegui, "[...] nos países (...), onde a maior parte da população é indígena, a reivindicação do índio é a reivindicação popular e social dominante" (Tradução Livre) (2008a, p. 64). Nesse contexto há uma inserção mais facilmente visualizada da questão indígena atrelada à dinâmica de relação capital versus trabalho, apresentando de maneira evidente o fator de classe na realidade deste sujeito da hiperpotentia. O que Mariátegui considera como um elemento de raça, ao tratar o indígena, deverá converter-se em um fator de classe e alimentar a perspectiva revolucionária.

Dessa forma, observa-se que o ator coletivo dessa hiperpotentia latinoamericana, parte de um sistema produtivo e de uma realidade parcialmente diversa do continente Europeu ou dos Estados Unidos, conforme já destacado em tópicos anteriores.

Assim, os camponeses e o proletariado das cidades são em grande parte compostos por indígenas e negros, parcelas do povo mais excluídas da lógica liberal estruturante do Estado, que devido às poucas oportunidades históricas e a maior exploração das economias periféricas, exercem as funções mais precarizadas do sistema. Apesar de atualmente, o conceito de raça ser visto com descrédito, no aspecto biológico, na esfera social e econômica ele é relevante. Mesmo os povos e as comunidades tradicionais, os quais se mantêm na exterioridade sistêmica, devido à lógica própria de vida que possuem e a perspectiva de exclusão que estão situados, servindo como potenciais formadores de um exército de reserva para o capital, são parcelas importantes para a conjunção desta hiperpotentia fomentadora da transformação da América Latina. Darcy Ribeiro acredita que não se trata de mera reserva de capital, mas da impossibilidade de incorporação do excedente da força de trabalho ao sistema produtivo moderno.

Nesse sentido, não são desempregados, porque não são empregáveis. Entretanto, como conseguem subsistir, ainda que 
precariamente, por seus próprios meios, isto indica que alcançam certa interação econômica com o sistema. (RIBEIRO, 1983a, p. 91).

Uma forma de organização econômica e social mais avançada na dinâmica do capital integrará esses povos ao que Darcy Ribeiro (1983a) considera como "proletariados externos", visto que por meio da exploração, sobretudo de transnacionais, fornecem commodities agrícolas e minerais, e consomem produtos industrializados, fomentando um capitalismo dependente.

Cabe pontuar que nesse momento não ousamos entrar nas minúcias da centralidade de qual grupo que compõem estes sujeitos terá maior força para construir esse bloco histórico unitário e puxar mais vigorosamente um processo revolucionário adiante. Mas, apresentar a importância de grupos relevantes diante do contexto estudado, os quais afetarão os caminhos de um processo transformador. Visto que o "Outro", termo utilizado por Dussel a partir dos estudos sobre as obras de Levinas, é constituído na exterioridade por serem sujeitos negados pela Modernidade (1993). Daí ser necessário destacar neste processo a negação do "Outro", latino-americano, e considerá-lo na dinâmica de construção da hiperpotentia que resgata a alteridade e com isso, constitui os direitos próprios destes povos.

A lição do amauta Mariátegui ainda ressoa como um desafio para a transformação latino-americana e marca a diferença e importância destes sujeitos potenciais compositores da hiperpotentia.

Es imprescindible dar al movimiento del proletariado indígena o negro, agrícola e industrial, un carácter neto de lucha de clases. Hay que dar a las poblaciones indígenas o negras esclavizadas - dijo un compañero del Brasil - la certidumbre de que solamente un gobierno de obreros y campesinos de todas las razas que habitan el territorio, los emancipará verdaderamente, ya que éste solamente podrá extinguir el régimen de los latifundios y el régimen industrial capitalista y librarlos definitivamente de la opresión imperialista. (MARIATEGUI, 2008a, p. 75). 
O recorte classista dado é fundamental para se construir uma sociedade a partir de um diferenciado modo de produção, da mesma forma que a pluralidade da composição desse grupo de trabalhadores. As transformações, além de emancipar a classe trabalhadora deverão preocuparse com a realidade do indígena, dos negros, dos excluídos sistêmicos e outros grupos que potencialmente compõem esta classe.

1.3.1. Os postulados políticos da hiperpotentia como estímulo à construção de um novo paradigma político

A partir da formação da hiperpotentia disposta a tomar o controle de seu próprio destino, abre-se uma perspectiva para a modificação do exercício da potestas. "A situação se complica quando movimentos sociais ou o povo descobrem novos direitos e lutam por seu reconhecimento [...]. Para a comunidade oprimida ou excluída, tais direitos criam nova legitimidade" (DUSSEL, 2007, p. 127). Nota-se a formação de uma nova cultura política emergente em decorrência das lutas sociais travadas e da quebra de hegemonia da classe dirigente mantenedora do status quo opressor.

Essa é uma dinâmica que Enrique Dussel sintetiza bem 0 procedimento de empoderamento do povo.

O poder do povo, como hiperpotentia crítica, constrói-se "em baixo" (e não só "de" baixo). Esse poder tem como sede o próprio povo. O que se "constrói" (não se toma) é a acumulação de força, a unidade; são as instituições e a normatividade subjetiva dos agentes. Depois vem o exercício delegado do poder (a potestas). Nesse sentido, a práxis de libertação é a própria “construção" (DUSSEL, 2007, p. 128). 
Esta práxis da libertação traz em sim características com potencial inovador de uma nova ordem, aspectos de criatividade, transformadores, os quais possibilitarão concretizar, inclusive, novas construções jurídicas a partir de postulados próprios de uma realidade adequada e emancipatória.

"Um "postulado político", repetindo, é um enunciado logicamente pensável (possível), porém impossível empiricamente, que serve de orientação para a ação" (DUSSEL, 2007, p. 135). Logo, postular uma sociedade sem classes, conforme o próprio Dussel exemplifica, deve ser uma das orientações políticas, as quais diagnosticam o problema da estratificação da sociedade em classes sociais e os efeitos disso.

Ao intencionar uma sociedade sem classes, é importante entender os meios usados que mantêm esta como reprodutora de desigualdades e dificulta a construção de novos paradigmas, inclusive jurídicos.

A teoria marxista da dependência, desenvolvida por intelectuais orgânicos e militantes latino-americanos, ajuda na compreensão da dominação de classe peculiar que assolam esses países e possibilitam uma orientação política diferenciada, a qual rompe com a estratificação classista (MARINI, 2005). Desenvolver essa teoria é fundamental para entender os efeitos do capitalismo a partir da realidade daqui e gerar reflexão acerca dos outros instrumentos constituídos nessa hegemonia liberal, os quais formatam as instituições vigentes e as superestruturas sociais.

Ao pensarmos na dominação estrutural que sofremos, devemos conjugar esses fatores os quais indicarão o perfil hegemônico que prevalece e a importância em desconstruí-lo. Sem essa análise, o estudo tenderá a desconsiderar elementos que compõe uma lógica própria para a América Latina. Algo que comprometerá outros campos, além do econômico, como o ecológico, o jurídico, o ideológico, etc.

O escopo do desenvolvimento econômico deve ser a potencialização da vida humana. Ao invés da precarização do trabalho, prezar-se-á uma maior qualidade laborativa e a redução de jornada, em um primeiro momento 
histórico. Para depois avançar através de medidas mais radicais que tenderão a romper com a lógica de subsunção do trabalho à dinâmica do capitalismo.

Assim, um postulado que preze uma sociedade sem classes possibilitará a constituição de um paradigma diverso do atual. Da mesma forma, outros postulados são necessário na orientação de práticas possibilitadoras da emancipação humana. Dussel (2007) trata da "vida perpétua", como postulado ecológico fundamental para a vida na Terra. É uma forma de evitar que a extinção da vida no planeta ocorra em decorrência das ações dos próprios seres humanos.

Para isso, as ações devem romper com a forma irracional de utilização dos recursos naturais. Isso deve-se em parte, à sanha do capitalismo em reproduzir-se, com a intenção de aumentar suas taxas de lucro, independente das consequências destas ações. Rever os hábitos individuais é importante, mas não o suficiente para reverter um quadro de esgotamento geral dos recursos. "Desde o começo da industrialização, no século XVIII, a população mundial cresceu 8 vezes, consumindo mais e mais recursos naturais; só a produção baseada na exploração da natureza, cresceu mais de cem vezes" (BOFF, 2001, p. 10). Caso a situação permaneça a mesma, ou seja intensificada, tenderá a um colapso em breve tempo.

Na América Latina a situação de devastação ambiental é aprofundada com a lógica de atuação das transnacionais, que se apropriam dos recursos disponíveis aqui, deixando ao país explorado tão só os prejuízos ambientais. Ainda há uma riqueza em biodiversidade, que atrai estes "investimentos" internacionais, os quais enxergam uma forma de obtenção de matéria-prima e força de trabalho barata. Logo, a luta por um postulado ambiental de preservação da vida humana implica na luta contra estas corporações, conforme ocorreu na Bolívia em meados do ano 2000. Na cidade de Cochabamba, a hiperpotentia manifestou-se diante da realidade boliviana, quando aquele povo expulsou a transnacional Bechtel, protegida pelo Governo Boliviano da época, que agia na sanha de privatizar a água e controlar os preços da mesma. Isto representou uma literal luta pelo direito à água. 
A orientação das ações a partir de um postulado que vise a "vida perpétua" diante de uma real interação homem/mulher-natureza, sem uma ação destrutiva e de exploração irracional, é a única saída para a continuidade da vida humana no planeta Terra em um longo prazo.

Além deste campo, um postulado que deve ser assegurado é o de respeito à interculturalidade e suas manifestações diversas. Afirmar-se através do meio de vida próprio, da crença, das línguas, dos valores, são formas de reprodução social legítima desenvolvida com o decorrer da história e particular vivência dos povos.

As manifestações culturais peculiares dos povos latino-americanos foram desprezadas por uma concepção trazida pela Modernidade, negadora dos valores e tradições produzidos por aqui. Mesmo os Estado modernos europeus não possuem uniformidade étnica, linguística em suas formações ${ }^{43}$, apesar de passarem a imagem de unidade do Estado nação, muitas vezes até negando grupos formadores daquela sociedade ${ }^{44}$.

Na América Latina, Estados como o México, Peru, Equador, Bolívia ou Guatemala, que possuem em seu seio grandes culturas milenares, colunas da história da humanidade, devem mudar suas constituições, seus sistemas de direito, o exercício judicial, a educação escolar, o tratamento da enfermidade, o exercício municipal delegado do poder político, dando autonomia em todos esses campos às comunidades indígenas em todos os níveis culturais e políticos. (DUSSEL, 2007, p. 145).

\footnotetext{
43“Na verdade, nenhum Estado moderno (Espanha, Reino Unido, França, Itália, etc.) tem como base uma nação, uma etnia ou língua, mas sim várias culturas, com línguas, histórias e até religiões diversas." (DUSSEL, 2007, p. 145).

${ }^{44}$ Basta remetermos a Estados como a Espanha, que tem uma parcela da população que se caracteriza como Catalã, a qual possui língua própria, costumes próprios. Outra parcela que se constitui como Bascos, tendo inclusive fomentado historicamente um exército separatista conhecido como ETA. Isto, sem remetermos historicamente a formação deste Estado com influências linguísticas e culturais diversas, sobretudo, pelos povos Mouros. A Bolívia poderá avançar nessas questões a partir da plurinacionalidade, algo que países como a Espanha possuem dificuldade em lidar.
} 
Isso seria uma forma de reconhecer o quão importante esses povos são para a formação plural dos respectivos Estados, sem que essa autonomia pudesse consistir em graves prejuízos ao projeto de sociedade emancipada. Esta reafirmação dos povos e busca de respeito pleno, desde um postulado intercultural, deve desenvolver-se sem desrespeito aos sujeitos da transformação e contribuindo para a mesma. Ações que ofendam ou gerem repugnância dentro da própria comunidade devem ser repensadas entre estes, a partir de vivências e do postulado estabelecido entre os próprios atores coletivos da hiperpotentia.

Todos estes postulados ao serem reproduzidos, e na tentativa de exercê-los, gerarão modificações e rupturas sistêmicas estabelecidas. Contribuirão, sobretudo, para a mudança de paradigmas. O paradigma pautarse-á por outro sistema, outra estrutura. Este só se viabilizará em decorrência da forma e intensidade das lutas encampadas pelos atores coletivos da hiperpotentia.

Podemos dizer que vivemos em um período de crises paradigmáticas, as quais devem ser desgastadas, até não se sustentarem, e possibilitarem o novo.

[...] a modernidade já não consegue cumprir outras das suas promessas. Tanto o excesso como o défice de cumprimento das promessas históricas, explicam a nossa situação presente, que aparece à superfície, como um período de crise, mas que, a nível mais profundo, é um período de transição paradigmática (SOUSA SANTOS, 2002, p. 49).

As crises paradigmáticas evidenciam-se quando está demonstrada a impossibilidade de se darem respostas às novas demandas postas, advindas com as lutas realizadas pela hiperpotentia. As instituições, consequentemente, não mais atendem os interesses de populares insatisfeitos com seu funcionamento. Sofrem assim, um processo de entropia, ou seja, um desgaste quase irreversível que demonstra a necessidade de instituições de novo tipo. 
Da mesma forma, ocorre com a ciência, que não mais dá respostas eficazes aos processos dinâmicos apresentados na vida. "Nestas condições, é legítimo pensar que a crise do paradigma da ciência moderna acarreta consigo a crise do paradigma do direito moderno" (2002, p. 164) conforme destaca Boaventura de Sousa Santos.

Assim, ao se propor postulados questionadores do status quo, reformulando os paradigmas existentes, está também lançado o desafio de repensar o direito ${ }^{45}$ e a política a partir de um novo paradigma. Para então constituir-se uma nova hegemonia jurídica na América Latina, os parâmetros serão outros, não mais um amontoado de garantias meramente individuais, eurocêntricas e de cunho liberal.

A hiperpotentia organizada terá o condão de ditar as mudanças advindas com as interpelações dos trabalhadores e oprimidos latinoamericanos, para que tenha força suficiente na modificação das estruturas postas. Assim, verificar-se-á até que ponto, experiências transformadoras ganharão o status de revolucionárias.

Esse bojo possibilitará o início de uma nova conformação política e jurídica, a partir de postulados diretivos e com perspectivas reais de reformulação de uma nova estruturação jurídica e política na América Latina. Paradigmas que deverão ser orientados, a partir das lutas sociais manifestadas pela hiperpotentia latino-americana, as quais não aceitam mais a insuficiência de garantias de direitos apresentadas pela Modernidade aos países periféricos e querem reconhecidos direitos próprios para um povo que necessita emancipar-se do jugo colonial e capitalista.

Aos pensadores que refletem sobre a importância de processos de ruptura com o "velho" e reconstrução do "novo" na América Latina, não podem repetidamente cometer o equívoco de pensadores anteriores, os quais buscavam universalizar conceitos que foram concebidos desde uma realidade

\footnotetext{
${ }^{45}$ Para Alexandre Bernardino Costa, "a mudança de paradigma no direito afeta também a prática dos Tribunais, Juízes, Ministério Público, Defensoria Pública, Advocacia, Administração Pública, Poder Legislativo, etc." (2005, p. 62).
} 
e contexto específicos e inapropriados ${ }^{46}$. Remetemo-nos às fontes e às contribuições de diferentes momentos e situações históricas importantes para reformularmos um projeto próprio.

Por isso, inclusive o sujeito da transformação deve estar em sintonia com o lócus e apresentar uma alternativa à construção hegemônica opressora. Para isso a compreensão do processo civilizatório e o fortalecimento de um projeto unificador para a América Latina é fundamental. Esse terá elementos, por vezes diferentes daqueles trazidos por trabalhadores/as e excluídos/as de outras partes do mundo, que possibilitarão emergir a práxis libertadora latinoamericana. Esta, que advinda com a hiperpotentia, resgatará nova ordem social, a partir da criatividade e das demandas genuínas deste povo.

Para isso, ainda resta forte mobilização popular, organizada e intencionada a romper com o sistema estabelecido, colonizador histórico das vidas e das mentes dos povos latino-americanos. Esses sinais de ruptura passam a ser vivenciados em determinadas situações, como na Bolívia.

\subsection{O contexto sociopolítico boliviano e os seus sinais transformadores}

A formulação de determinados parâmetros para reflexão social é uma etapa inconclusa de qualquer análise a ser realizada. Parar nesse ponto é satisfazer-se com os elementos fornecidos pela teoria, sem sequer constatá-los na realidade.

Antes mesmo disso, cabe apreciar as informações debatidas em um cenário concreto. Cenário esse, detentor de um processo histórico próprio, com peculiaridades políticas, econômicas e sociais que cabem ser destacadas. $O$ cenário dessa pesquisa é a Bolívia.

${ }^{46}$ Cf. HEGEL, 1999. 
Esse país, cravado ao centro da América Latina, merece destaque pelos relevantes acontecimentos históricos e, no início do século $X X I$, pelas mudanças apreendidas em âmbito institucional a partir das lutas populares. A realização de um recorte temporal servirá para tratar de algumas questões que ajudam a entender a atualidade boliviana até o momento que nos interessa, e situar a promulgação da Constituição do, agora, Estado Plurinacional da Bolívia em 2009.

Ao invés de recorrer a toda uma leitura histórica da Bolívia desde os tempos coloniais ou mesmo na sequência da fundação do Estado boliviano, correndo o risco de tornar o trabalho enfadonho, além de desviar o objetivo do mesmo, tratarei de iniciar a abordagem a partir do período da Revolução de $1952^{47}$, seguindo pelos aspectos finais do regime autoritário, o ascenso e crise neoliberal e a lógica democrático-representativa na sequência.

Um autor que fornece um grande auxílio para se compreender o panorama político boliviano é o intelectual marxista, nascido em Oruro, René Zavaleta Mercado. Ele foi uma figura influente no país, sobretudo durante a segunda metade do século XX. O desenvolvimento das ciências sociais na Bolívia deriva muito desse autor, inclusive as categorias que trabalhou, facilitaram a compreensão das particularidades da formação do povo boliviano, a exemplo da noção de nacional-popular. Ele aborda esse conceito considerando-o possível, somente, ao trazer à tona as figuras dos mineiros e indígenas em contraposição à elite senhorial racista (ZAVALETA MERCADO, 2008).

Zavaleta utiliza a crise como método principal de apreensão da realidade social boliviana. Isso é facilmente visualizado em seus trabalhos, cabendo um destaque para o clássico "Las masas en noviembre" (2009), o qual remete às mobilizações populares que marcam o período final da ditadura no país nos idos de 1979.

As reflexões desse momento final da década de 70 na Bolívia podem ser feitas através dos blocos históricos. Zavaleta Mercado aponta o conflito

\footnotetext{
47 A Revolução de 1952 foi um momento de insurgência popular que levou o governo revolucionário a democratizar setores da sociedade boliviana, além de fazer a reforma agrária. Ela teve um forte caráter nacionalista, não se atentando para a construção étnico-cultural plural da sociedade boliviana. Ela perde sua essência com um golpe em 1964.
} 
existente entre o bloco dominante que possuía a hegemonia no período ditatorial, formado por setores das forças armadas que compunham o governo. O bloco que trazia um projeto distinto apresentou uma aliança do campesinato $^{48} \mathrm{sob}$ a direção do proletariado mineiro cuja bandeira principal era a concretização de princípios e as eleições democráticas na sociedade. A crise social serviu para fragilizar o bloco dominante, que se fragmentava em seu interior, a ponto de alguns setores da burguesia deixar de apoiá-lo deslegitimando fortemente sua atuação. "Desde a Revolução de 1952, momento máximo de autodeterminação das massas na Bolívia, houve um confisco constante da liberdade popular", aponta Rafaela Pannain (NO PRELO). A autodeterminação das massas ou a manifestação da hiperpotentia, de fato, se fazia presente, a partir daquela formação social "abigarrada", como diria Zavaleta Mercado, permitindo a convivência de esparsos capitalistas juntamente com atividades pré-capitalistas.

La producción comunitaria o parcelaria en la Bolivia alta, por ejemplo, no sólo es distinta en su premisa temporal agrícola a la oriental, por el número de cosechas y las consecuencias organizativas del trabajo del suelo, sino también a la minera, que es ya la supeditación o subsunción formal en acción. El único tiempo común a todas estas formas es la crisis general que las cubre, o sea la política. La crisis, por tanto, no sólo revela lo que hay de nacional en Bolivia, sino que es en sí misma un acontecimiento nacionalizador. Los tiempos diversos se alteran con su irrupción. Tú perteneces a un modo de producción y yo a otro, pero ni tú ni yo somos los mismos después de la batalla de Nanawa; (...) (ZAVALETA MERCADO, 2009, p. 216).

O autor boliviano chama a atenção dessa diferenciação do modo de produção no seio social aymara, para o que Álvaro Garcia Linera tratará como forma comunitária ou forma comunidade (2008). Essa convive com o modo de produção capitalista dependente na Bolívia e a crise foi o elo que unificou $o$

\footnotetext{
48 "A atuação dos camponeses aymaras durante a crise, na aliança formada em defesa da democracia representativa, marcava uma virada na sociedade boliviana, pois, desde a Revolução de 1952, os camponeses haviam servido de base de sustentação dos governos, inclusive durante o regime autoritário inaugurado com o golpe de 1964". (PANNAIN, NO PRELO).
} 
universo composto pela classe trabalhadora junto a essa classe comunal, dando um caráter nacional e popular ao movimento das massas no final dos anos 70 .

A composição da sociedade boliviana permitirá compreender a dinâmica das lutas populares. O mesmo Garcia Linera, atual vice-presidente da Bolívia, trata dessa composição enfatizando a diferenciação de regimes civilizatórios existentes, algo que vai além da mera diferenciação do modo de produção. Pois, integra "a matriz cognitiva e os procedimentos de autoridade que regulam a vida coletiva [...] podendo atravessar vários modos de produção". (2008, p. 231). Para ele seriam quatro tipos basicamente. O moderno mercantil-industrial, que é focado nos indivíduos com atividades voltadas ao mercado (mineração, indústria, atividades assalariadas, comércio...) e aos serviços em geral, representando ao redor de 20 a $30 \%$ das pessoas envolvidas com isso no país. O segundo grupo é daqueles que desenvolvem a atividade mercantil de forma artesanal ou até mesmo dentro da dinâmica camponesa (desde camponeses arrendatários de terra até artesãos). Esse segmento social compõe aproximadamente $68 \%$ do emprego urbano caracterizado pela informalidade ${ }^{49}$. No terceiro grupo está a civilização comunal e sua forma própria de funcionamento e desenvolvimento, caracterizado pela gestão comunal da terra e familiar possuindo suas próprias instituições e autoridades. Por fim, a civilização amazônica, com seu caráter itinerante de produção e sendo o grupo que sofreu a maior ausência histórica do Estado. (GARCIA LINERA, 2008, p. 232-234).

Uma sociedade em que só, aproximadamente $1 / 4$ da população participa diretamente do processo produtivo deve olhar também para outros possíveis setores capazes de comporem a vanguarda compartilhada responsável pelo processo transformador na Bolívia para além do proletariado. Mesmo que seja compreensível sua centralidade, devido à presença do próprio processo de dependência do capital.

\footnotetext{
49 "La agricultura está compuesta de 550 mil unidades domésticas que abarcan al $90 \%$ de la población agraria. En el trabajo urbano predominan 700 mil unidades semiempresariales, en tanto que el $65 \%$ de empleo urbano lo otorgan estas unidades semiempresariales y familiares." (ARCE, 1999).
} 
1.4.1. As formas de organização social na Bolívia

Em sua obra clássica, $A$ potência plebeia, Garcia Linera trata de diferenciar as formas de organização dos/as lutadores/as do povo bolivianos/as. Isso permite verificar os instrumentos que terão maior capacidade de enfrentamento às estruturas capitalistas e coloniais, além de indicar quais terão maior capilaridade e capacidade de mobilização na sociedade boliviana.

A forma sindicato é o tipo clássico de organização proletária no mundo, e não seria diferente na Bolívia. Nessa situação, poder-se-á deparar concretamente com a subsunção real dos/as trabalhadores/as ao capital, permitindo a organização do movimento sindicalista. Essa forma organizativa irá gerir aqueles que atuam na produção massiva de bens e possibilitam um maior acúmulo de capital (GARCIA LINERA, 2008, p. 276).

A forma sindical possibilitou à auto-organização dos trabalhadores/as e configurou um espaço de exercício pleno de participação e construção democrática direta nas decisões das categorias. Visto que se constrói uma cultura que busca consensos e democracia assembleística naquele ambiente. Esse caráter dava o tom da atuação e da tomada de decisões sindicais. Da mesma forma, que em outros países da América Latina, o reconhecimento dos sindicatos ocorre no fim dos anos 30 e começo dos 40 do século $X X$. A criação de legitimidade com o reconhecimento do Estado e os contratos com tempo indeterminado, garantindo maior vínculo dos trabalhadores/as à sua função laboral, (GARCIA LINERA, 2008, p. 277-280) contribuiu para o êxito da forma sindical na organização de parte dos trabalhadores/as bolivianos.

Diante dessa conjuntura, essa forma de organização da classe trabalhadora assumiu a liderança das lutas e unificou as ações centrais de 
atuação dos trabalhadores/as, constituindo o instrumento principal de uma vanguarda política. A Revolução Nacional de 1952 teve êxito e derrotou a oligarquia boliviana a partir dessa força político-organizativa, onde a estrutura sindical configurou-se como polo aglutinador das lutas populares, capaz de dirigir as massas naquele período histórico.

Poucos dias após a Revolução surge a COB - Central Obrera Boliviana - que contribui para a consolidação desse processo. A COB ainda seria, ao longo de algumas décadas, a principal voz da sociedade boliviana.

Houve um tempo em que a política tinha como cenários os quartéis e as grandes assembleias operárias. Era o tempo em que as elites se coligavam em torno dos oficiais do exército com mando de tropa e em que a sociedade exercia os seus direitos de cidadania por meio dos sindicatos e organizações em escala nacional (COB). Ditadura militar e cidadania sindical eram os pólos ordenadores do campo político de 1964 até 1982. (GARCIA LINERA apud IAMAMOTO, 2011, p. 39).

Já no início da década de 80, com o fim da ditadura e reestabelecimento do regime democrático, o então presidente da República, Victor Paz Estenssoro, assina o decreto 21.060 de 1985, o qual prevê um radical corte nos gastos do Estado. Conforme observa Sue lamamoto, essa medida "[...] causou a demissão de 23 mil mineiros ( $80 \%$ do total). O decreto marcou o início do período neoliberal de reformas estruturais no país" (2008, p. 39).

Nessa época inicia-se o enfraquecimento do Estado com a crescente política de privatização e fragiliza-se a luta sindical, sobretudo da $\mathrm{COB}$ como instrumento de protagonismo político na direção das massas. Os trabalhadores/as desempregados passam a compor os grandes bolsões de trabalho informal das grandes cidades ou retornam ao campo. No entanto, levam consigo a forma organizativa e disciplina política sindical, as quais servem em momento posterior para fomentar as lutas no período de crise neoliberal. 
Alguns intelectuais optam por trabalhar com outra forma de organização para também compreender a realidade boliviana. A "forma multidão”. A categoria será apresentada pela importância dada a ela por vários intelectuais-orgânicos progressistas bolivianos, mas opto por não trabalhar com a mesma, visto que as categorias já trabalhadas até aqui, como classe, povo, hiperpotentia e bloco histórico são suficientes à análise realizada.

$\mathrm{Na}$ Bolívia, ao verificar nas insurreições de 1979, a união do proletariado inssurrecionalista e o uso de métodos políticos da luta agrária que rememorou a composição de alianças da Revolução Nacionalista de 1952, Zavaleta caracterizou aquilo como manifestações da "multitud", ou multidão (2009, p. 219). Como salientado, essa categoria da "mulltitud" é, posteriormente, trabalhada por outros autores e autoras como Álvaro Garcia Linera, Raquel Gutierrez, Antonio Negri, Michael Hardt, etc.

Esses dois últimos, Antonio Negri e Michael Hardt, desenvolvem profundamente a categoria, mas não a trabalham desde as formas reais e concretas de enfrentamento ou articulação entre as lutas políticas, econômicas presentes na sociedade (NEGRI; HARDT, 2005). Tratam mais de uma mera forma de organização em uma utilização quase abstrata do termo.

Ao contrário de Negri, os autores/as do grupo Comuna ${ }^{50}$ dão maior concretude, identificando o sujeito coletivo que atua nessa multidão. Essa foi uma forma muito usada para tratar das manifestações ocorridas após a crise neoliberal com as lutas populares no início do século XXI.

No contexto boliviano, esses intelectuais orgânicos ligados ao Comuna, usavam o termo multidão ou multitud ${ }^{51}$ (em castelhano) ao tratar da construção

\footnotetext{
50 "O grupo Comuna existe desde finais dos anos 1990, e teve como indiscutíveis membros não necessariamente em todos os momentos - os cinco intelectuais e militantes citados, que serão chamados aqui de membros orgânicos do grupo. O núcleo de organização do grupo, no seu começo, foi sem dúvida composto por Álvaro García, Raquel Gutierrez, Luis Tapia e Raúl Prada", além de Oscar Vega Camacho. Além de militantes políticos, o "grupo que proporcionava um espaço de discussão política constante e semanal, no qual se reuniam muitos militantes e intelectuais para discutir política e conjuntura boliviana, e por outro lado publicava livros assinados coletivamente." (SANTAELLA GONÇALVES, 2013, p. 51).

51 Uma diferenciação terminológica fundamental é a distinção de mutitud, conforme está exposto nesse tópico, do termo muchedumbre, que na língua castelhana também significa
} 
desse corpo de sujeitos coletivos em momentos de crise, os quais a formação transcendia as características clássicas da formação da classe trabalhadora. Estrutura essa concebida de forma horizontal com ênfase na tomada de decisões via participação direta da sociedade, muitas vezes através da assembleia. Diferentemente da ideia de participação liberal, que preza a racionalidade individual.

O poder político emanava de um discurso hegemônico desde a perspectiva trabalhadora e popular, além de possuir uma capacidade aglutinadora e de encaminhamentos adequadas aos problemas daquele momento histórico, o qual permitia imaginar uma ordem política alternativa a partir daquele contexto de ação (GUTIERREZ et.al., 2007, p.177).

A multidão se configuraria nas crises, concebida como uma associação de associações onde havia uma mescla de identidades sociais, e até certo ponto, classe, sem uma direção muito clara. Esse termo foi tão debatido, que foi tema central de seminários e obras para aprofundá-lo (NEGRI et. al., 2008).

Contudo, mesmo que a "multidão" seja um termo importante no contexto estudado, observa-se no processo histórico que apesar da existência do sujeito coletivo, que está à frente das lutas mais recentes na Bolívia, ele prescinde de uma vanguarda compartilhada para dirigir o processo. Sem uma direção, algo que não fica claro na multidão, não haveria uma alternativa construída de outro projeto político para substituir o, então, vigente.

A última forma de organização popular que cabe destaque é a forma comunidade. Para além dos sindicatos ou da "multidão", boa parte de indígenas-camponeses se organizam em ayllus ${ }^{52}$ a partir da forma comunidade, sobretudo aqueles que vivem no altiplano andino. A estrutura civilizatória, cultural, política e tecnológica são distintas das praticadas, em geral, pelos campesinos, e mais distintas ainda dos trabalhadores urbanos. $O$

multidão. Contudo, a muchedumbre refere-se à mera articulação de indivíduos com pautas e organizações fluídas. (LINERA, 2004, p. 44-45) .

52 Configura um modo de organização tradicional andina, proveniente dos antepassados incas, caracterizado pela utilização de um determinado quinhão de terra, trabalhada, via de regra, de forma coletiva em território comum, sendo alguns deles, vinculados ao mercado urbano. 
exercício de poder comunal e descentralizado são reivindicações históricas desses grupos sociais frente ao Estado.

A CONAMAQ - Conselho Nacional de Ayllus y Markas de Qullasusyu a partir de 1997, busca reconstituir esses territórios ancestrais com a recuperação e estímulo aos ayllus existentes e as suas formas comunitárias de funcionamento ${ }^{53}$.

\begin{abstract}
A organização CONAMAQ tinha como projeto de larga escala a busca da reconstrução do Qullasuyu, parte sul do Império Inca, baseando-se em mapas coloniais, em reconstruções históricas e no trabalho nas comunidades, com oficinas e atividades dirigidas nesse sentido. Os objetivos do CONAMAQ à época da Assembléia eram conseguir incluir na Constituição o direito à livre determinação, para exercer o autogoverno e a autonomia das nacionalidades e dos povos indígenas originários; com a meta de alcançar o Sumaq Qamaña (Viver Bem), conceito que foi introduzido na política pelo katarista Simón Yampara, segundo ele mesmo. Os modos para obtê-lo: reconstituindo o território, restituindo as autoridades do ayllu, e fortalecendo o governo do Qullasuyu. (SCHAVELZON, 2010, p. 82).
\end{abstract}

Os comunários em geral ${ }^{54}$, diferentemente dos campesinos, trabalham em propriedades coletivas e não tem como objetivo imediato a mercantilização da sua produção. Uma boa parte da produção dos ayllus serve para o abastecimento das comunidades através das relações correntes entre as famílias da localidade.

\footnotetext{
${ }^{53}$ O conselho de governo da CONAMAQ era formado pelos seguintes ayllus constituídos e em processo de reconstituição: "Jach'a Karanga; Jatun Killaka Asanajaqi; Charka Qhara Qhara; CAOP; Ayllus de Cochabamba; Jach'a Pakajaqi; Sura; Uru; Kallawaya. (...)Chuwi; Qulla; Larikaja; Yampara; Pueblo afro descendiente, Yapacaní y comunidades originarias de Tarija." (CONAMAQ, 2008, p. 6).

54 "Otras comunidades en cambio, algunas ubicadas en las provincias de Franz Tamayo, Muñecas, Bautista Saavedra, Loayza, pese a los cambios de 1952, no han logrado la plena consolidación de la base para cualquier autonomía económica, la soberanía de la posesión territorial, y entonces mantienen vínculos de dependencia con hacendados o sus descendientes que aún controlan el poder comercial y político local. Sin embargo, la mayoría de las comunidades-ayllus que han sostenido las movilizaciones son estructuras productivas, culturales y de filiación que combinan modos de organización tradicionales con vínculos con el mercado (...)" (GARCIA LINERA, 2008, p. 309)
} 
Si bien es creciente la parte del producto familiar que se incorpora al mercado y del consumo que se necesita complementar con productos urbanos, no estamos ante campesinos plenamente mercantilizados ni ante comunidades resultantes de la mera agregación de propietarios privados. La comunidad se presenta como una entidad social de vínculos tecnológicos, formas de circulación de bienes y personas, transmisión de herencia, gestión colectiva de saberes y recursos, sedimentación de experiencias, funciones políticas y proyección de porvenir que se antepone y define a la propia individualidad. El mercado de tierras que lentamente se viene practicando en el altiplano, está regulado por compromisos y responsabilidades comunales; la fuerza de trabajo no circula de manera prioritaria como mercancía y si bien existen formas primarias de mercantilización recubierta por la ideología de la reciprocidad, la principal fuente de abastecimiento de fuerza productiva son las redes parentales (...) (GARCIA LINERA, 2008, p. 309-310).

Ao analisar o funcionamento do capitalismo dependente na América Latina, nota-se que o modo de produção dominante, além de exploratório, possui um caráter racista, proveniente da herança colonial. Ao deparar essa estrutura com a estrutura da forma comunidade, observar-se-á uma composição civilizatória completamente diferente e suas variadas dimensões, além de não ser concebida desde um critério racista para sua reprodução.

A própria democracia comunal demonstra essas diferenças. Os comunários encaminham seus acordos construindo consensos a partir de um horizonte de ação comum. Assim, eles/as criam um caráter vinculativo ao cumprimento desses acordos pelos sujeitos coletivos e individuais, tendo valor de norma o estabelecido (GARCIA LINERA, 2008, p. 323). Não é necessário que um representante, em nome da comunidade, crie uma norma em um ambiente institucional para que ela seja cumprida e tenha validade. É a possibilidade de construção de um "sujeito coletivo de direito", capaz de instaurar novas práticas políticas, abrir espaços sociais inéditos, bem como criar e afirmar direitos (SOUSA JÚNIOR, 1997). O modo democrático desenvolvido nos ayllus extrapola os mecanismos liberais de democracia e enfrenta o caráter monista dado às normas jurídicas. 
A lógica organizativa aliada aos saberes produzidos in locu permite avançar nas mobilizações, quando preciso, e cria um sentimento de pertença ao modelar a subjetividade coletiva através da reprodução cultural e das lutas populares historicamente tocadas por esses grupos que vivem nos ayllus.

Por mais que atue em um sistema próprio, com uma dependência diminuta em relação à reprodução do capital, Zavaleta Mercado (2009, p. 216) destaca que nos momentos de crise geral, comunários ou não, todos são atingidos de alguma forma. Seja em âmbito politico ou econômico revelando, então, o aspecto nacional do Estado, que o autor também trabalha.

Essa relação do modo de produção dominante e a existência de outros que se reproduzem em espaços como os exemplificados nos ayllus, através da forma comunidade, serve para compreender, inclusive, as formas de minar as estruturas do capitalismo periférico desenvolvido em um Estado liberalmente montado. Marx já apontou para essa possibilidade no fim da vida, nos idos de 1881, ao abordar sobre o potencial comunista das comunas agrárias na Rússia (1982) na carta que escreve à Vera Zassúlitch. Dessa forma, extrapola a ideia de caminho único, e aponta uma não linearidade da história, enfatizando a "possibilidade de um retorno transformado de elementos de uma comunidade pré-capitalista em condições superiores - isto é, universais-comunistas". Não se trata de um retorno agrário nostálgico, mas uma possibilidade atual, em um cenário de universalização do capitalismo e troca desigual internacional, de rearticular comunismo e comunidade (BOSTEELS, 2013, p. 101).

1.4.2. Aspectos da estrutura capitalista boliviana no século $X X$ : um enfoque marxista a partir dos Grundrisse.

A lógica capitalista na Bolívia não é movida, em grande parte, por uma estrutura industrial. A maioria dos trabalhadores e trabalhadoras não estão 
subsumidos diretamente ao capital. Conforme, já salientado no ponto anterior, não passam de $30 \%$ os trabalhadores/as que compõem a massa mercantilindustrial do país.

Zavaleta Mercado elenca em um de seus clássicos, Lo nacionalpopular em Bolívia, a maneira de estruturação histórica do capitalismo boliviano. Une a inserção da economia do país à lógica imperialista e dependente, estimulada pelo capital, ao destacar a fase de extração de estanho e prata, aliado ao aristocrático reacionarismo agrário (2008, p. 87). Ambas atividades são de fundamental importância para as economias centrais efetivarem a troca desigual, mantendo a Bolívia como um país pobre e exportador de commodities.

En cuanto la acumulación originaria, que se dirige hacia la construcción del mercado generalizado, se puede decir que es también un momento constitutivo de la nación en el sentido capitalista. (...). La expansión del latifundio y el triunfo estatal del libre cambio sin duda configuraban un momento de tal acumulación. (ZAVALETA MERCADO, 2008, p. 164).

Os investimentos junto ao capitalismo periférico boliviano reforçavam essa postura dependente frente aos países dos grandes centros econômicos. Além disso, a acumulação originária possibilitou a criação de um proletariado composto basicamente por indígenas e mestiços, amparado na dominação racial manifestada através do desenvolvimento capitalista.

A Bolívia não teve sua economia plenamente desenvolvida pelo capitalismo. Lá permaneceram intactas inúmeras estruturas comunitárias de funcionamento próprio, as quais se mantiveram em boa parte da existência histórica, sem qualquer relação com o mercado. Hoje, a maioria exerce alguma relação de troca e complemento com a economia capitalista urbana, mas ainda possuem autonomia frente a esse mercado capitalista pelo padrão e modo de vida que levam, como destacado no tópico anterior. 
No século XIX, Marx ao esboçar as linhas gerais do que seria sua obra clássica, O Capital, traça impressões gerais a respeito do dinheiro, do próprio capital e da forma de manifestação e desenvolvimento do modo de produção. Essas notas que tratam da crítica à economia política, escritas em 1857-1858, ficaram conhecidas como os Grundrisse.

Um tópico em especial interessa à pesquisa ora desenvolvida. Aquele que trata das formas que precederam a produção capitalista. A crescente ampliação do mercado mundial e a constante necessidade de expansão do capitalismo para superação das crises criadas por ele mesmo, fez com que Marx estivesse atento à reprodução social e econômica na Ásia e, em alguma medida, na América. $O$ intelectual comunista apresenta as condições para o trabalho e caracteriza 0 momento da desvinculação do trabalhador $\mathrm{e}$ trabalhadora da terra para gerar força de trabalho para o capitalismo. A terra, sendo o meio e a base material de trabalho, daquele que detinha uma pequena propriedade ou da propriedade comunitária, a partir das experiências asiáticas.

Nessas duas formas, os indivíduos não se relacionam como trabalhadores, mas como proprietários - e membros de uma comunidade que ao mesmo tempo trabalham. A finalidade desse trabalho não é criação de valor - embora eles possam realizar trabalho excedente para trocá-lo por trabalho alheio, i. e., produtos excedentes -; ao contrário, a sua finalidade é a conservação do proprietário singular e de sua família, bem como a da comunidade como um todo. (MARX, 2011a, p. 388)

Essas duas formas de funcionamento, mesmo com o desenvolvimento do modo de produção capitalista, se mantêm em larga escala. A atividade camponesa baseada na agricultura familiar e inserção no mercado, tanto quanto a atividade indígena-comunitária, ainda forte nos altiplanos andinos, estão presentes na configuração "abigarrada" de funcionamento da sociedade boliviana.

Nessas situações, "a terra é o grande laboratório, o arsenal, que fornece tanto o meio de trabalho quanto o material de trabalho, bem como a 
sede, a base da comunidade" (MARX, 2011a, p. 389). Assim, o excedente produzido pertence tão somente a esse camponês ou à comunidade que o produziu. Naquela comunidade o avanço das práticas agrícolas pode fomentar o surgimento de manufaturas locais e criação de autossuficiência contendo as condições necessárias a maior produção e reprodução da vida (MARX, 2011a, p. 389). Isso é verificado na organização da forma comunidade e sua relativa autonomia frente ao mercado boliviano. Assim, a produção de excedentes pode ser distribuída nessas ou fora dessas comunidades, sem afetar, e boa parte das vezes, sem ser afetado, pela estrutura hegemônica do modo de produção capitalista estabelecido ${ }^{55}$.

Essas comunidades não tendem a uma incorporação automática à lógica do modo de produção hegemônico. As atividades desenvolvidas desde uma lógica pré-capitalista ${ }^{56}$ de produção e de outro regime civilizatório ocorrem nos dias atuais, sem o ranço "feudal" ou "atrasado" que se situava quando Marx analisava essa questão. Ele não estudou os povos indígenas e suas características desde a realidade andina, muito menos os conflitos sociais ali correntes, a relação com o Estado e a elite, as contradições presentes, entre outras questões fundamentais.

Uma vez mantida a estrutura civilizatória das comunidades que habitam os ayllus, desde a forma comunitária, cria-se condições diferenciadas de produção na atualidade. As formas de associação e controle da produção podem ser aprimoradas, as condições atuais de tecnologia e desenvolvimento são outras, bem diferente do que era na época de Marx, a presença massiva do proletariado, produtor direto de riqueza e potencial aliado das comunidades na luta frente às medidas políticas e econômicas que atingem esses grupos trazem um panorama distinto.

\footnotetext{
55 "Mas, o fato de que a história pré-burguesa, e cada fase sua, também tem a sua economia e uma base econômica do movimento, no fundo, é a simples tautologia de que a vida dos seres humanos desde sempre esteve baseada na produção, de uma ou de outra maneira, na produção social, cujas relações chamamos justamente de relações econômicas." (MARX, 2011a, p. 400-401). Conforme destacado, relações econômicas não necessariamente capitalistas.

${ }^{56}$ Ou um socialismo indígena.
} 
Esse cenário não indica um desaparecimento natural desse modo de vida comunitário com o desenvolvimento da sociedade. Isso se dará, tão somente, com a possibilidade de imposição predatória do modo de produção capitalista dependente sobre essas comunidades, algo que ainda não foi efetivado em larga medida na Bolívia. Da mesma forma, imaginar que o desenvolvimento da sociedade, inclusive dos ayllus que vivem em forma comunitária, só ocorrerá com a inserção capitalista nessas comunidades para uma posterior ruptura socialista é repetir uma ortodoxia vulgar, negadora do materialismo histórico dialético e entorpecida por uma colonialidade do saber sem igual. $O$ direcionamento da luta de classes tende a mostrar para onde seguirão essas comunidades.

Ao tratar do processo de acumulação primitiva do capital ocorrerá uma separação entre produtor direto e os meios de produção. Algo que, como visto, ocorreu parcialmente na Bolívia. Essa separação será fundamental para o avanço do modo de produção capitalista. Uma das condições para a expansão do capital é a verificação da subsunção real ou formal do trabalho a ele. Isso indicará o alcance e seu potencial de desenvolvimento.

De acordo com a abordagem que Marx faz da categoria, a subsunção formal ocorre após o momento da separação entre produtor direto e proprietário, estando o primeiro subordinado ao último através da venda da sua força de trabalho em troca de salário. Subordinação essa, em regra, amparada na violência e imposição da exploração. Esse é o momento que o valor de uso transmuta-se em valor de troca e o sistema capitalista ganha fôlego extraindo predominantemente do trabalhador/a mais-valia absoluta ${ }^{57}$. Karl Marx definirá a categoria como "a forma geral de todo o processo capitalista de produção; mas é ao mesmo tempo uma forma particular, a par do modo de produção especificamente capitalista [...]" (1978, p. 51).

Assim, a expropriação dos trabalhadores/as possibilitará aos proprietários ou possuidores diretos dos bens de produção, a extração de mais-

\footnotetext{
57 A mais-valia absoluta é caracterizada quando se explora mais os trabalhadores/as para acúmulo e reprodução do capital.
} 
valia através dessa subsunção formal e a retribuição salarial, obviamente, menor que o valor gerado com o trabalho.

No decorrer do avanço capitalista, as forças produtivas também se desenvolvem e agregam valor ao capital constante com a inserção tecnológica. Logo, surgem as máquinas que substituem, em parte, o trabalho dos assalariados/as. A partir desse ponto inicia-se a extração da subsunção real do trabalho. Pois, a relação de exploração ocorre do trabalhador/a assalariado/a em decorrência da ação da máquina extraindo, então, a mais-valia relativa ${ }^{58}$.

\begin{abstract}
Enquanto o trabalho em máquinas agride o sistema nervoso ao máximo, ele reprime o jogo polivalente dos músculos e confisca toda a livre atividade corpórea e espiritual. Mesmo a facilitação do trabalho torna-se um meio de tortura, já que a máquina não livra o trabalhador do trabalho, mas seu trabalho de conteúdo. Toda produção capitalista, à medida que ela não é apenas processo de trabalho, mas ao mesmo tempo processo de valorização do capital, tem em comum o fato de que não é o trabalho quem usa as condições de trabalho, mas, que, pelo contrário, são as condições de trabalho que usam o trabalhador: só, porém, com a maquinaria que essa inversão ganha realidade tecnicamente palpável. (MARX, 1978b, p.43).
\end{abstract}

O sistema capitalista desenvolvendo-se gera uma maior concentração de renda e riqueza, e o movimento do capital acaba possibilitando a concentração de mercados e formação de oligopólios, como alertou Lenin em sua obra sobre o imperialismo, já tratada aqui. O efeito desse cenário potencializado é uma maior miséria e exclusão social no globo, enquanto menos pessoas ficam mais ricas.

Nota-se que na Bolívia, existe um parque industrial limitado e com isso uma subsunção real pouco efetiva. No capitalismo boliviano prevalece a produção de mais-valia absoluta, através da subsunção formal do trabalho ao capital, pois se trata de um país, ainda hoje, grande extrativista commodities

\footnotetext{
${ }^{58}$ A mais-valia relativa, devido ao incremento tecnológico, permite uma maior produção em um mesmo tempo gasto. Logo, não há aumento de valor, o grau de exploração do trabalhador/a mantem-se, mas haverá um número maior de mercadorias produzidas do que sem os aparatos tecnológicos intensivos.
} 
minerais e agrícolas, além de ter um reduzido valor da força de trabalho ${ }^{59}$. Uma vez que a economia capitalista periférica alimenta as economias centrais, criase uma dependência imposta nessa troca desigual impulsionada pelas políticas imperialistas.

\begin{tabular}{|l|r|}
\hline DESCRIPCION: BOLIVIA EXPORTACIONES & $\mathbf{2 0 1 2}$ \\
\hline EXPORTACIONES (Miles de dólares estadunidenses) & $\mathbf{1 1 . 7 9 3 . 6 7 3}$ \\
\hline Agricultura, Ganadería, Caza, Silvicultura y Pesca & 524.904 \\
\hline Extracción de Hidrocarburos & 5.870 .952 \\
\hline Extracción de Minerales & 2.074 .252 \\
\hline Industria Manufacturera & 3.323 .564 \\
\hline
\end{tabular}

Tabela 01 - Descrição das exportações bolivianas em 2012.

Fonte: (INE, 2012)

Contudo, já se salientou que parte da produção boliviana não serve ao mercado automaticamente, mas fomenta os ayllus, através da forma comunidade. Algumas vezes, a produção que excede às necessidades comunitárias é direcionada ao mercado consumidor. Assim, em geral, ao invés do valor de troca fomentado pelo capitalismo, trata-se de exercício do valor de uso com a produção de bens que fazem parte da necessidade comunal e é socializado naquele meio. "O valor é já uma propriedade social incorporada ao produto, o trabalho em troca é a atividade viva fundadora dessa propriedade, mas exterior à corporalidade do produto" (tradução livre) (LINERA, 2009, p. 49). Logo, o trabalho exercido nos ayllus, não são reificados por não estarem subsumidos ao capital, mas tão só para produzir valor a partir da necessidade do produto para a comunidade. O valor será determinado pelo processo social responsável por sua produção.

Importante atentar-se que a territorialidade social de cada ayllu é regida pela própria comunidade e não por outros ayllus ou confederações de ayllus.

\footnotetext{
${ }^{59} \mathrm{O}$ problema não está restrito a ausência de industrialização, mas também na redução do valor da força de trabalho boliviana, dos seus respectivos bens-salários essenciais para a sobrevivência dos trabalhadores/as.
} 
Eles constituem-se como diversas nações formadas, basicamente pelo povo aymara. Ademais, a propriedade familiar existente dentro dos ayllus, não reproduz a propriedade privada moderna do capitalismo. Ou seja, mesmo que as famílias estejam responsáveis pelo uso da terra, ao invés do uso comunitário, a terra existe como patrimônio familiar direcionado à comunidade, diferenciando-se da propriedade privada da terra que terá sua produção transformada em mercadorias.

En estas condiciones, (a) la socialidad histórica similar (de formas de trabajo y propiedad de la tierra, de forma social del producto basada en el valor de uso, de historia sojuzgada, de discriminación y exclusión, de cultura, de cosmovisión expansiva), existente como contenido objetivo unificante, y, (b) las estrategias inter-ayllus de reconstrucción histórica de la validez de su existencia a través de la retotalización comunal de la totalización colonial-mercantil (desde la participación en condiciones favorables en el cambio mercantil, la preafirmación del espacio del ayllu incorporando a los migrantes, el mantener lazos de comunión festiva-religiosa con los que parten de el dirigiendose a otros ayllus o a actividades urbanas, hasta el proyecto de emancipación general del poder colonialrepublicano), en tanto sustancialización subjetiva de una politicidad fusionada de todos los ayllus como nación, son los que desempeñan ahora el papel de motor, la fuerza aglutinante que va separando las viejas fronteras locales étnicas (materialmente ya disgregadas por el dominio colonial y republicano) y creando una frontera tendencialmente nacional ante el poder colonial (español, republicano, estatal-boliviano). De este modo, al tiempo de recrearse la unificación primordial (familiar-comunal), de darle certeza histórica, se extiende la definición de espacio social de nación a varios grupos autónomos, pero a la vez independientes, en este terreno de la reproductividad, de la imaginación de ella, de sus formas naturales objetivadas. (GARCIA LINERA, 2009, p. 219).

Essa forma de funcionamento dos ayllus, nos faz pensar em formas não só antigas e anteriores ao capitalismo, mas pós-capitalistas. Visto que a forma capitalista busca sempre a expansão, uma alternativa ao capitalismo deve ser universal. Os mecanismos de funcionamento dos ayllus, em que não 
há uma submissão do trabalho ao capital e, consequentemente, do valor criado, apontam para uma possibilidade que parte da base da sociedade e terá condições de enfrentar o capital desde que seja passível de universalização, ou seja, tendo condições de expandir-se. O trabalho cooperativo tende a ser a forma organizativa mais palpável ao funcionamento dessa força social de trabalho, sendo a produção um momento de criação compartilhado entre a comunidade e construído a partir de um universo cultural e simbólico vivos e não alienantes. As relações de trabalho tendem a uma linha ética entre as pessoas e concebida conforme as variáveis apresentadas pela natureza, sem a lógica de extração crua, da mesma forma que os avanços tecnológicos são comunitários $^{60}$ e atendem esses princípios de solidariedade e comunhão ambiental.

A produção comunal tem suas temporalidades técnico-produtivas que são subsumidas socialmente à produção estabelecida. Logo, é importante o ritual coletivo para uma produção consciente e desejada, satisfazendo a comunidade sem entrar em atrito com a natureza, nem com os deuses que espiritualizam o ambiente (LINERA, 2009, p. 300). Para os povos aymara, a pachamama é considerada ser sagrado, por isso a terra não é tratada da mesma maneira que no modo de produção capitalista. Os territórios dos ayllus são assim não passíveis de mensuração pecuniária, pois permitem uma

\footnotetext{
60 "Véase por ejemplo la riquísima tecnología simbólica familiar-comunal de las antiguas y contemporáneas comunidades (aunque en estas últimas, ya de una manera unilateral y fragmentada por 500 años de colonización desestructurante), mediante la cual se fija el inicio de la laboriosidad agrícola, las variaciones en el momento del inicio de las lluvias, de su intensidad, de las posibilidades de granizada, etc., todas ellas imprescindibles para el desarrollo de la eficacia productiva. Aquí se destacan: (a) los métodos de observación de los cuerpos celestes (el sol y la luna, de las constelaciones); (b) los fenómenos atmosféricos (adelanto 0 atraso de los vientos, la existencia de remolinos, la presencia de nubes al amanecer, su comportamiento los primeros dial de agosto, la humedad de ciertas piedras, el nivel de agua de algunos pozos, el adelanto o atraso de las nevadas, color de las aguas del lago, etc.); (c) el comportamiento de los animales y las plantas (observación del momento de la floración de la kamantira, itapallu, qariwa; la calidad de la formacion del llachu, de la yarita, waraqu; momento de la aparicion de las patankayas para establecer el fin de la época de lluvias; nacimiento de las crías del jarankuja o la pérdida de su cola para decidir el sembrado de papas; el aullido del kamaki para el inicio de la siembra; el lugar del nido del tuqi o qenola cerca del lago para precisar la ausencia o abundancia de lluvias; el lugar del nido del liqi-liqi en las pampas para establecer si el año será seco o húmedo, etc; la presencia de ciertos animales en el momento de la siembra para preveer buena o mala cosecha); (d) de los signos espirituales (lectura de la hoja de coca, interpretación de los sueños, etc.)." (S. YAMPARA, MAMANI apud GARCIA LINERA, 2009, p. 309-310).
} 
relação interativa entre homem/mulher-natureza-espírito, desde uma cosmovisão construída socialmente naquele meio.

O que se buscou foi apresentar a estrutura econômica organizativa dos ayllus como uma possibilidade existente e que está além do capital. Existem também ayllus inseridos na dinâmica do mercado, inclusive com um grau de dependência, que compromete o funcionamento da comunidade uma vez não realizada a venda de excedentes, conforme destaca Garcia Linera em seu clássico, Forma valor y forma comunidade.

En unos casos, la estructura interna de un tipo de comunidad es tan estable y cohesionado que le ha permitido sobrevivir con ligeras transformaciones por cientos de años, hasta ser lentamente disgregada, utilizada, fragmentada y explotada por el colonialismo capitalista contemporáneo, como sucede con la comunidad aymara-qhiswahasta nuestros días. En otros casos, por propio desarrollo interno, han surgido jerarquías y divisiones irreconciliables e incontrolables que han diferenciado, en primer lugar, el ámbito de lo público y lo privado; según las especificidades históricas, esto puede dar lugar en ciertos casos a una lenta sustitución de la propiedad comunal por la propiedad privada a medida que se produce la autonomización del control comunal sobre la familia constituida. (2009, p. 353).

A intenção não é construir uma visão idealizada e romântica de processos concretos que possuem diversos problemas para manterem um modo de produzir e viver relativamente autônomo à dinâmica de mercado. Mas, por outro lado, é demonstrar que existem alternativas possíveis, como essa economia comunitária, que ocorrem paralelamente à expansão do capital e não apresentam sinais de desaparecimento. Ademais, apesar de hegemônico, o capitalismo é algo que está em movimento se impondo, mas também sofrendo resistências e adaptando-se ao avançar das lutas, podendo em determinado momento histórico, ser rompido.

A sobrevivência dessas experiências será possível somente com 0 fortalecimento da unidade entre os ayllus, que em alguns momentos revestiu- 
se em organização sindical, robustecendo a produção comunal, que não deve limitar-se à comunidade e avançando nessa dinâmica criadora comunitária como um projeto para além do âmbito regional. O contexto da luta de classes forjará o destino da classe comunal.

1.4.3. Katarismo e o resgate da identidade indígena rebelde no contexto democrático liberal

Um fator que trouxe um caráter diferenciado para as manifestações de massa ocorrida em 1979 foi a influência do movimento katarista ${ }^{61}$, que se fortaleceu no início dos anos 70. Esse movimento foi influenciado pelo capital étnico que com outros capitais econômicos, culturais, simbólicos e sociais contribuem para a diferenciação de classe na Bolívia (GARCIA LINERA, 2008, p. 218), como também já foi destacado por Mariátegui ao tratar do Peru.

A Revolução Nacionalista de 1952 homogeneizou o tratamento dado ao indígena boliviano como se mero camponês fosse. Isso demonstrou uma desconsideração da própria reprodução cultural e social das várias etnias indígenas, por parte do Estado, naquele período. Esse discurso de caráter moderno, proveniente dos manuais de economia política, criava uma impossibilidade epistemológica e uma barreira cognitiva incapaz de compreender a realidade do local onde ocorria aquele processo transformador. Tanto é que as medidas do Estado àquele momento eram democratizantes, mas desconsideravam a formação do povo, ou a "sociedade abigarrada", que Zavaleta Mercado se refere. Tanto é, que as mudanças seguiram também esse padrão moderno, como implemento do voto universal, reforma agrária clássica,

${ }^{61} \mathrm{O}$ termo katarismo refere-se à Tupac Katari, liderança aymara que lutou contra as autoridades coloniais espanholas no período que precedeu a independência da Bolívia. 
educação formal pública e gratuita, mas que naquele momento não rompia com a colonialidade dos saberes (LANDER, et. al., 2005).

As inquietações e manifestações públicas de questionamento a essa política começa a ocorrer, tendo como grande interlocutor das comunidades indígenas bolivianas o intelectual Fausto Reinaga ${ }^{62}$. Ele foi responsável por formar, reivindicar e refletir sobre a questão identitária e o pensamento indígena em suas obras (REINAGA, 1970).

Assim, reinicia-se um processo de organização e reconhecimento indígena na Bolívia. Uma das ações importantes nesse sentido foi o Manifesto de Tiwanaku assinado em 1973 por inúmeras organizações. Essas admitiram os avanços da Revolução Nacionalista de 1952 para os povos indígenas, mas denunciaram a manutenção da estrutura colonial, além da invisibilidade étnica que esses povos sofriam.

Os indígenas atuaram não só nas formulações de uma nova epistemologia para a realidade boliviana, mas também agiram concretamente, como destaca Linera.

(...) el discurso katarista indianista, a fines de los años setenta, se va a dividir en cuatro grandes vertientes. La primera, la sindical, que dará lugar a la formación de la Confederación Sindical Única de Trabajadores Campesinos de Bolivia (CSUTCB), (...). La otra vertiente es la política partidaria, no solamente con la formación del Partido Indio, a fines de los años sesenta, sino del Movimiento Indio Túpak Katari (MITKA) y el Movimiento Revolucionario Túpak Katari (MRTK), (...) La tercera vertiente, al lado de la política y la sindical, será la corriente académica, historiográfica y de investigación sociológica. (2008, p. 381)

\footnotetext{
62 “Nós, índios, não somos 'camponeses' da categoria do Gal. Barrientos Cantinflas e seus parasitas. Não somos 'camponeses' que integram a sociedade do cholage branco-mestiço. Não. Isso não somos. (...) Nós somos índios, filhos de Pachakútej, Tupaj Amaru, Tomás Katari, Tupaj Katari, Pablo Atusparia, Zárate Willka. Somos deste trigo e deste pão." (REINAGA apud IAMAMOTO, 2011, p. 43).
} 
A fundação da CSUTCB - Confederação Sindical Única de Trabalhadores Campesinos da Bolívia - concebendo um sindicato agrário unificado, que tem por base as estruturas indígenas tradicionais de autoridades, foi fundamental para garantir o processo organizativo e de mobilização indígena posteriormente, indo além das pautas tão só campesinas. Daquele momento em diante, o indígena não mais deveria ser "transformado" em mero camponês. Um reducionismo classista inaceitável para o rompimento das estruturas coloniais de poder. Já no ano 2000 fundou-se ainda, um partido institucionalizado, o Movimento Indígena Pachakuti sob a liderança de Felipe Quispe.

Rememorando as lições de Mariátegui, atrelar a condição de classe à questão indígena é fundamental para uma mudança não anacrônica e, tampouco, dogmática. Os povos em análise são campesinos, mas também indígenas. Tratando-se de classes que sofrem com o modo de produção capitalista e a reprodução das políticas coloniais pelo Estado, além de possuírem grande potencial revolucionário, sem sobreposição automática do trabalhador/a ou camponês ao indígena. Até porque, a maioria dos sujeitos que estão nas cidades também é mestiça ou indígena (BOLIVIA, 2013a). Sem a unidade dessas classes não seria possível revolucionar as bases do Estado Boliviano.

Toda essa postura das organizações indígenas encadearam os primeiros elementos para o aprofundamento do debate a respeito da plurinacionalidade.

Da mesma forma, por mais que a bandeira da democracia representativa tenha ganhado eco com as manifestações de 1979, a estrutura de classe da sociedade boliviana manteve-se inalterada e as organizações indígenas não aceitavam mais esses avanços limitados. A Bolívia não possui, concretamente, um sistema político-econômico moderno, logo o exercício político e cidadão dos bolivianos/as não pode se limitar à democracia representativa de cunho liberal. A estrutura implantada não corresponde à realidade local e a sua forma de exercício político, que vai muito além do voto 
individual em algum representante. Zavaleta questionava a democracia representativa e afirmava que na Bolívia ainda "uns homens morriam como cães para que outros comessem como porcos. Essa é a pátria da injustiça social" (tradução livre) (2009, p. 239).

La lógica de la representación —un hombre, un voto- sólo es válida donde los hombres son iguales al mínimo. En Bolivia, los núcleos de la decisión polític (policymaking) se sitúan en las tres ciudades principales, en dos 0 tres centros de concentración campesina y en los distritos mineros. Se puede decir que quien triunfe en esos puntos perentorios tiene el poder, aunque no tenga la mayoría. Tal es el grado en que la democratización real califica (determina) la validez de la forma representativa democrática. (ZAVALETA MERCADO, 2009, p. 245-246).

Logo, a reconquista das garantias liberais, como a democracia representativa, era insuficiente, algo que o período neoliberal demonstraria anos mais tarde. O Estado reorganiza seu sistema político nas décadas de 80 e 90, também a partir dos partidos políticos, inclusive com a participação de grupos que se mantinham fora da organização institucional. A igualdade individual permitida, através do voto, camuflava a desigualdade estrutural, no que tange ao não reconhecimento da cultura e reprodução da vida das várias etnias indígenas. Para Luis Tapia, a redução da democracia à mero método de seleção de governantes é parte de um discurso colonialista eurocêntrico e anglo-saxão. A democracia toma uma forma definitiva, a partir de um produto de uma cultura e tempo histórico específico das sociedades modernas, em particular, na cultura política liberal (2009a, p. 74). A democracia representativa não criou mecanismos para reconhecer as formas de organização política, de tomadas de decisão, o idioma e a lógica cultural dos povos e nações que vivem na Bolívia.

Além dos partidos, aumenta o número de organizações populares após a década de 80. Destacam-se algumas outras, além da COB e CSUTCB já tratadas: Confederação de Povos Indígenas da Bolívia - CIDOB -, Conselho Nacional de Ayllus y Markas de Qullasusyu, - CONAMAQ -, Frente Nacional de 
Mulheres Camponesas da Bolívia - Bartolina Sisa - FNMCB-BS -, Central Operária Regional de El Alto - COR - e as Juntas de Vizinhos - FEJUVE -.

1.4.4. A hegemonia neoliberal em crise

O início do século XXI traz à Bolívia um período de insurgências. Algo que mobilizou a sociedade, como poucas vezes na história, entre os anos de 2000 e 2005. Essas insurreições populares não foram características exclusivas da sociedade boliviana, mas em diversos países da América Latina, as massas populares foram às ruas. Isso foi tão significativo, a ponto de elegerem como representantes máximos, líderes populares ligados às forças progressistas $^{63}$ por todo o continente.

Na Bolívia destacam-se dois momentos históricos de maior mobilização e luta política nesse período. A Guerra da Água é uma delas e ocorre de janeiro a abril do ano 2000, movida pela intenção em privatizar o sistema de abastecimento de água na cidade de Cochabamba. A outra ficou conhecida como Guerra do Gás, ocorrida no ano de 2003, em decorrência da tentativa de venda do gás natural boliviano aos Estados Unidos através dos portos chilenos.

Ambas medidas neoliberais geraram grande mobilização. Além de nenhuma dessas medidas institucionais terem prosperado em decorrência das lutas populares, em 2005 cai o presidente Carlos Mesa e são convocadas novas eleições presidenciais, as quais elegeram Evo Morales como presidente da Bolívia.

\footnotetext{
${ }^{63}$ Destaque as eleições presidenciais de um militar revolucionário na Venezuela, um militante operário no Brasil, um economista anti-imperialista no Equador, um guerrilheiro tupamaro no Uruguai, um padre da teologia da libertação no Paraguai e um sindicalista cocalero na Bolívia, o qual se tratará na sequência, entre outros.
} 
Primeiramente, cabe salientar que a política econômica do período neoliberal boliviano foi dirigida, no início, por partidos que no decorrer histórico possuíam um cunho nacionalista, como o Movimento Nacionalista Revolucionário - MNR, com Victor Paz Estenssoro a frente como presidente. Assim, por conta também da força e pressão neoliberal internacional, 0 programa político do partido opositor, Ação Democrática Nacionalista - ADN -, foi implementado pelo até então, partido com características revolucionárias e nacionalistas.

A implementação das reformas, com a nova política econômica, proveniente do decreto 21.060 , teve um enorme êxito em controlar a inflação e estabilizar macroeconomicamente a Bolívia, devido ao apoio do setor financeiro e de negócios do país e das instituições de fomento internacionais, conforme destaca Santaella (2013, p. 44). Contudo, no pacote dessas medidas econômicas vinha o desemprego crescente, a diminuição do valor real dos salários, a crise entre os pequenos empreendimentos, etc. Enfim, efeitos que atingiam diretamente a vida do povo.

No decorrer da década de 90 as medidas neoliberais ainda eram aprofundadas através de investimentos estrangeiros e medidas de privatização, potencializando também as consequências sociais disso. Os desempregados seguiam continuamente para o mercado informal, inchando as regiões metropolitanas das grandes cidades. Aprofundou-se o rompimento da economia "moderna" e globalizada com a economia campesina, gerando maior precariedade de vida também no campo ${ }^{64}$.

As ONGs também tiveram um papel preponderante nesse período, visto que o Banco Mundial criou fundos de emergência social, para amenizar os efeitos devastadores das políticas neoliberais (RODRíGUEZ-CARMONA, 2009). O Estado deixava de cumprir sua função de provedor de políticas sociais para que as ONGs cumprissem esse papel, de forma insuficiente e sem

\footnotetext{
64 "Romper los lazos de articulación entre, por una parte, la economía moderna y globalizada del país, que abarca a cerca del $28 \%$ de la población boliviana y, por otra, la economía campesina tradicional compuesta por 550.000 unidades familiares $(35 \%$ de la población boliviana) y la economía mercantil familiar-artesanal de los 700.000 establecimientos urbanos que agrupa al $37 \%$ de la población nacional”. (GARCIA LINERA, 2008, p. 353).
} 
um rígido controle. Ademais, a promulgação da Lei de Participação Popular, 1.551 de 1994, incrementou a descentralização administrativa do Estado, por meio dos municípios, e propiciou um fortalecimento das elites econômicas regionais, que ganharam maior controle político das regiões onde se localizam. O grande exemplo disso é o fortalecimento da elite empresarial de Santa Cruz de la Sierra que passa a ocupar cargos fundamentais na estrutura do Estado.

A conjuntura apresentada gerou uma insatisfação dos diversos grupos que compunham a classe subalterna e sofriam as ingerências do neoliberalismo. Isso possibilitou a formação de um bloco histórico contra hegemônico responsável por ações que mudariam os rumos da Bolívia. A especialista em sociedade boliviana, Sue lamamoto, apresenta de forma clara, como os grupos sociais subalternos foram atingidos pelas políticas neoliberais, sendo compreensível a reação que ocorrera no início dos anos 2000.

Para operários, [o neoliberalismo] significou a morte do pouco "capitalismo de Estado" que havia na Bolívia, o fim simbólico de sua grande expressão organizativa durante o século $\mathrm{XX}$, a COB. Para camponeses, significou a deterioração dos preços dos seus produtos e o avanço de políticas que afetavam a economia agrária; mas, politicamente, também significou a subordinação ao imperialismo norte-americano com relação às políticas antidrogas. Para indígenas, deixou os seus territórios ainda mais vulneráveis a forças externas agressivas (madeireiras, petroleiras, privatização da água, latifundiários); mas também representou um aparato estatal externo invasivo, incapaz de compreender e incorporar a territorialidade indígena. Foi a população urbana pobre, indígena e vinculada ao setor informal a que cresceu com a crise que afetou todas as temporalidades, e que passou a viver em cidades que não contavam com serviços públicos capazes de atender às suas demandas mínimas vitais (educação, saúde, moradia, emprego). (2011, p.60). 
1.4.4.1. As lutas populares e a formação do bloco histórico contrahegemônico subalterno ${ }^{65}$ ou o bloco indígena-popular.

O neoliberalismo modifica a estrutura organizativa do mundo do trabalho, alterando em alguns aspectos, tanto a forma de produção como da organização dos trabalhadores/as. O aumento do número de desempregados e inchaço dos trabalhos informais dá uma nova roupagem ao proletariado da Bolívia. Essa nova configuração proletária retira da $\mathrm{COB}$, e consequentemente do proletariado mineiro, o papel de aglutinador imediato, instrumento de convergência e protagonismo nas lutas populares.

Isso não quer dizer que o proletariado não passa a ter importância ou força política para enfrentar a seara hegemônica neoliberal ou, muito menos, que deixam de existir ${ }^{66}$, como preferem acreditar alguns na esteira dos pósmodernos. O que se constata é o término de uma forma de configuração geral das condições de produção, tal qual estabelecido no decorrer do século XX, e da constituição clássica do sujeito político (GARCIA LINERA et. al, 2007a). Assim, o fechamento das minas, como uma das medidas neoliberais, desempregou e fragmentou a classe trabalhadora boliviana ${ }^{67}$. O pesquisador

\footnotetext{
65 A conceituação do bloco histórico contra-hegemônico subalterno parte da categoria gramsciana de classes subalternos, a qual constitui um recurso teórico-metodológico importante para a análise das lutas de classes na Bolívia. Pois, possibilita agregar grupos sociais que não são formados diretamente na divisão capitalista do trabalho. Assim, alia-se à classe trabalhadora explorada na lógica capitalista ao conjunto de grupos excluídos e marginalizados da dinâmica de controle e dominação hegemônica do capital.
}

${ }^{66}$ Marx aponta a essencialidade do proletariado para o fim da exploração do homem/mulher pelo homem/mulher através do capitalismo e o/a considera como sujeito fundamental para uma revolução, mesmo que existam outros sujeitos a serem considerados. "O desenvolvimento histórico peculiar da sociedade alemã excluía a possibilidade de qualquer desenvolvimento original da economia burguesa, mas não a sua crítica. À medida que tal crítica representa, além disso, uma classe, ela só pode representar a classe cuja missão histórica é a derrubada do modo de produção capitalista e a abolição final das classes - o proletariado." (MARX, 1983, p. 18).

67 "Es la muerte, entonces, no del sindicalismo, sino de una particular manera material y simbólica de ser del sindicalismo que ya no existe ni va a existir más. Es también la muerte de una forma de la condición obrera y del movimiento obrero y no así del Movimiento Obrero que en los siguientes años podrá adoptar otras formas históricas." (GARCIA LINERA, 2008, p. 293294). 
Rodrigo Santaella é preciso ao analisar como efeitos do neoliberalismo, um maior enfraquecimento dos Estados de economias periféricas, como a Bolívia, e;

[...] a retomada de uma ofensiva dos países centrais na exploração direta dos recursos e mão de obra das periferias, o capitalismo vigente toma formas semelhantes às do colonialismo, e as lutas anticapitalistas passam a conectar-se diretamente com as lutas anticoloniais (2013, p. 164-165).

As lutas decorrentes dos efeitos das políticas neoliberais propiciou a formação de uma unidade popular boliviana, agregando sindicatos de trabalhadores, organizações sociais indígenas, camponeses, juntas de vizinhos e trabalhadores informais. Atrelado a essa unidade, dando densidade à luta de massas, forjam-se as novas lideranças e aparecem os/as intelectuais orgânicos/as desse processo histórico ${ }^{68}$. Esse bloco histórico robusteceu-se com claras bandeiras anticapitalistas e anticoloniais para enfrentar 0 neoliberalismo implantado, resgatar princípios soberanos e reformular a dinâmica democrática. $O$ fortalecimento dessas mobilizações, a partir do ano 2000, abre a possibilidade para a reflexão a respeito das novas formas organizativas de luta e mobilização popular.

1.4.4.1.1. A guerra da água

O primeiro episódio marcante que evidencia a crise neoliberal na Bolívia, nos idos do ano 2000, ocorre em Cochabamba, como já destacado. A empresa estadunidense Bechtel Enterprise Holdings, juntamente com um

\footnotetext{
68 "La autoconciencia significa históricamente creación de una vanguardia de intelectuales: "una masa" no se "distingue" y no se hace "independiente" sin organizarse y no hay organización sin intelectuales, o sea sin organizadores y dirigentes. Pero este proceso de creación de los intelectuales es largo y difícil, como se ha visto en otras partes" (GRAMSCI, 1984, p. 300).
} 
consórcio de empresas, formou a Águas de Tunari, através da qual controlariam a distribuição de água em Cochabamba. Uma ação articulada pelo Banco Mundial e o governo boliviano.

As deficiências do sistema de água na cidade eram claras. Um pouco mais da metade da população recebia a cobertura do sistema de águas da cidade, a outra metade ou compravam água de caminhões que retiravam das cisternas ou abasteciam-se através de um sistema autogestionado (KRUSE, 2005, p. 136). O serviço não era prestado com a devida qualidade, sendo frequentes os racionamentos e interrupções no fornecimento. Justamente pela situação precária no fornecimento de água, os sistemas autogestionados se proliferaram.

Os investidores estrangeiros buscavam garantias que 0 empreendimento pudesse dar certo, e o governo boliviano fez o que estava ao seu alcance para obter a confiança dos investidores. Além de um contrato garantindo benefícios e uma grande margem de ganho às empresas ${ }^{69}$, a lei 2.029 de 1999 legalizava os investimentos estrangeiros em Cochabamba amparados pela lógica neoliberal.

O estopim estava aceso para a Guerra da Água e a pauta das manifestações estava colocada: a anulação da Lei 2.029 e o rompimento do contrato de concessão.

Nesse momento entra em ação um sujeito coletivo importante nessa batalha: a Coordinadora por la Defensa del Agua y la Vida, que funcionava como uma grande organização articuladora das comunidades, sindicatos, associações populares e atuou como mobilizadora desses atores no enfrentamento realizado contra o governo. Um grande agente da Coordinadora, nessa luta, foi a associação de regantes, os quais possuíam uma história com a temática da água e tinham condições de propor alternativas ao projeto

\footnotetext{
69 "Las negociaciones eran absolutamente secretas, y estaban protegidas por cláusulas de confidencialidad férreas. Divulgar su contenido o cualquier otra información calificada de confidencial era efectivamente ilegal por la duración del contrato más cinco años: este pacto clandestino entre empresarios y elites se protegería potencialmente por 45 años." (KRUSE, 2005, p. 143).
} 
neoliberal implementado. Além dos novos atores, reaparecem os sujeitos coletivos mais antigos nessas novas demandas como CSTUCB, Juntas de vizinhos, cocaleiros, etc. Em janeiro do ano 2000, as manifestações se intensificavam, era a vitalidade da hiperpotentia manifestada, e o governo oferecia pouca margem de negociação reprimindo com a ação da polícia e prisão de manifestantes. Em fevereiro, as manifestações tomaram grandes proporções e o povo ocupou a praça principal da cidade de Cochabamba, mesmo com as tropas do governo trazidas diretamente de La Paz.

A Coordinadora del Agua organiza em Março uma consulta popular, fomentando a democracia direta já que nada era feito pelo governo, para que o povo opinasse a respeito das tarifas, do contrato realizado e do abastecimento de água. Mais de 50 mil pessoas participaram da consulta e mais de $95 \%$ dos votantes rechaçaram a privatização (KRUSE, 2005, p. 148). Isso não sensibilizou o governo, que desqualificou a legitimidade da consulta.

Diante desse cenário foi convocada uma manifestação que teve início no dia 04 de Abril, que seria conhecida como a "batalha final". Essa insurgência popular gerou a ocupação da sede da Aguas de Tunari, marchas em vários pontos, bloqueios no campo, inclusive em outras regiões do Altiplano andino, nas áreas urbanas e a formação de barricadas em vários pontos da cidade. Os militares uniram-se aos policiais e a repressão aumentou, com inúmeros feridos e a morte de um jovem de 17 anos e outros tantos na região do altiplano. 


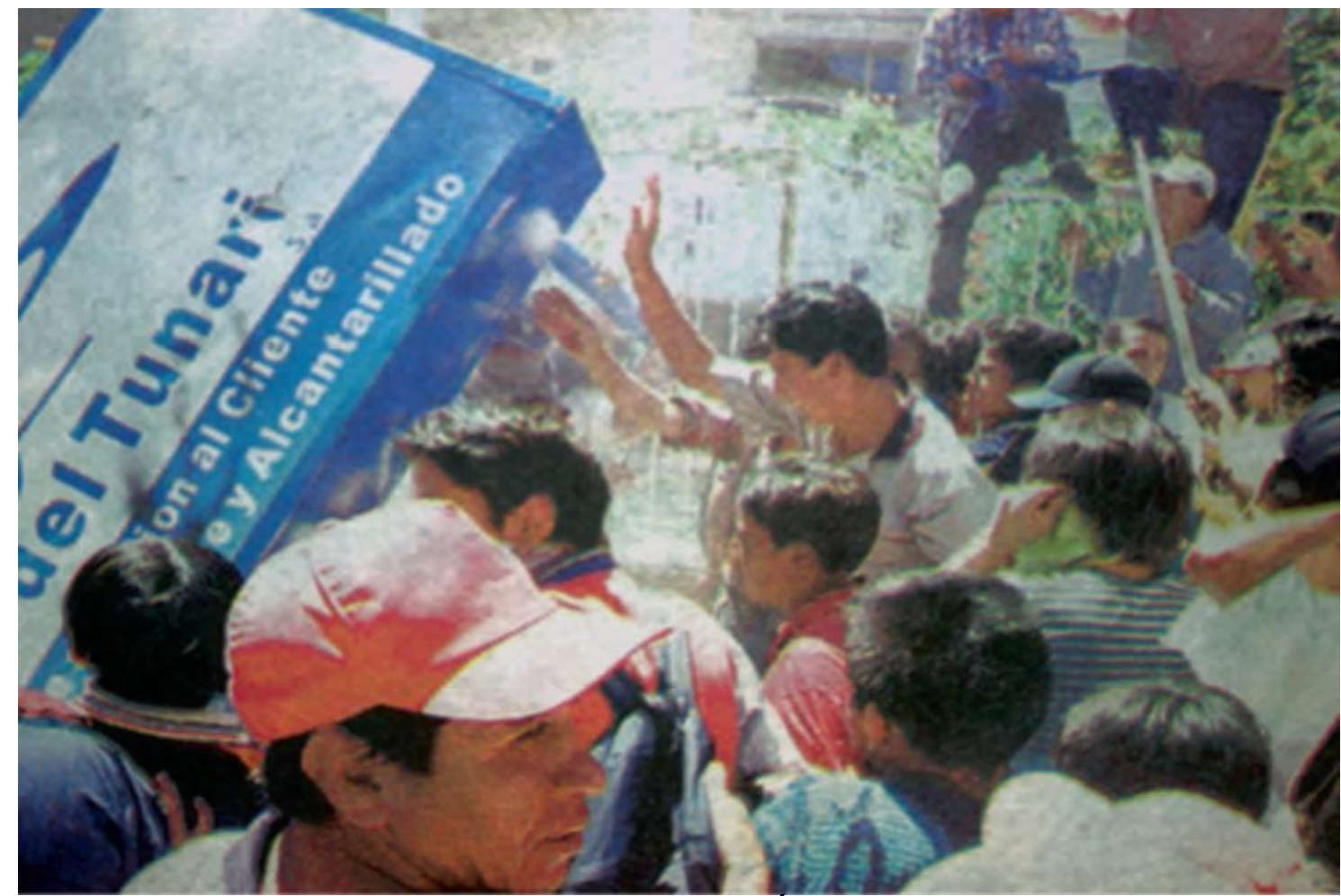

Foto 01 - População toma o escritório da empresa Águas de Tunari em Cochabamba. Fonte: (HEMEROTECA, 2000)

No dia 10 de Abril, o governo aceita os pedidos da Coordinadora de Agua, retirando a Aguas de Tunari da Cochabamba, liberando os presos nas manifestações, e reformulando a lei 2.029, algo que representou uma vitória do povo cochabambino contra a privatização do sistema de água. (KRUSE, 2005, p. 150).

\subsection{A guerra do gás}

Outro episódio a ser destacado na história recente da Bolívia, o qual demonstra uma virulenta reação do povo à tentativa de imposição da agenda neoliberal ficou conhecida como guerra do gás em 2003.

Antes desse episódio paradigmático, os sujeitos sociais coletivos já estavam mobilizados, empreendendo diversas lutas, sobretudo, as 
comunidades indígenas. Uma demonstração disso foi, ainda no final do ano 2000, o bloqueio das vias que davam acesso à La Paz, além de bloqueios de estradas durante três semanas afetando o abastecimento do Estado. Já em 2002, parte desses povos se levantam na "batalha da coca", em decorrência da tentativa de erradicação da folha de coca, demandada pela política externa dos Estados Unidos. Isso era um sinal que as classes subalternas e excluídas da sociedade boliviana estavam organizadas, dispostas a lutar e não aceitavam as imposições neoliberais impostas pelo governo.

No ano de 2003, já no governo do presidente Gonzalo Sánchez de Lozada, uma das medidas a serem tomadas era da venda do gás natural boliviano aos Estados Unidos através dos portos chilenos. O governo estava disposto a manter uma política que prezasse as privatizações e exportações de recursos naturais. Esses recursos fazem parte do sistema de reprodução cultural e social dos camponeses e das comunidades indígenas, logo privatizalos, significaria retirar algo inerente às comunidades.

O epicentro das mobilizações em torno dessa bandeira ocorre em El Alto, cidade na região metropolitana de La Paz. Em 1950, havia um pouco mais de 11 mil habitantes, já em 2010, a população da cidade girava em torno de 1,1 milhões de habitantes, ou seja, mais de $10 \%$ de toda população ${ }^{70}$ da Bolívia, condensando boa parte da sociedade boliviana em uma localização específica (PRADA, 2004, p.103). Essa explosão populacional em El Alto caracterizou a cidade como local de concentração de trabalhadores/as, sobretudo informais, predominantemente pobres e a grande maioria de origem indígena. Ademais, a estrutura organizativa de bairros, amparada nas experiências históricas agrárias e de trabalhadores/as, sobretudo mineiros, ajuda na compreensão da capacidade de mobilização e organização da população de El Alto.

\footnotetext{
70 “La población de Bolivia aumentó de algo más de 2,7 millones de habitantes en 1950 a más de 10 millones de habitantes en el año 2012, lo que significa que el tamaño de la población se multiplicó cerca de cuatro veces durante el periodo de 62 años." (BOLIVIA, 2013a, p. 4).
} 


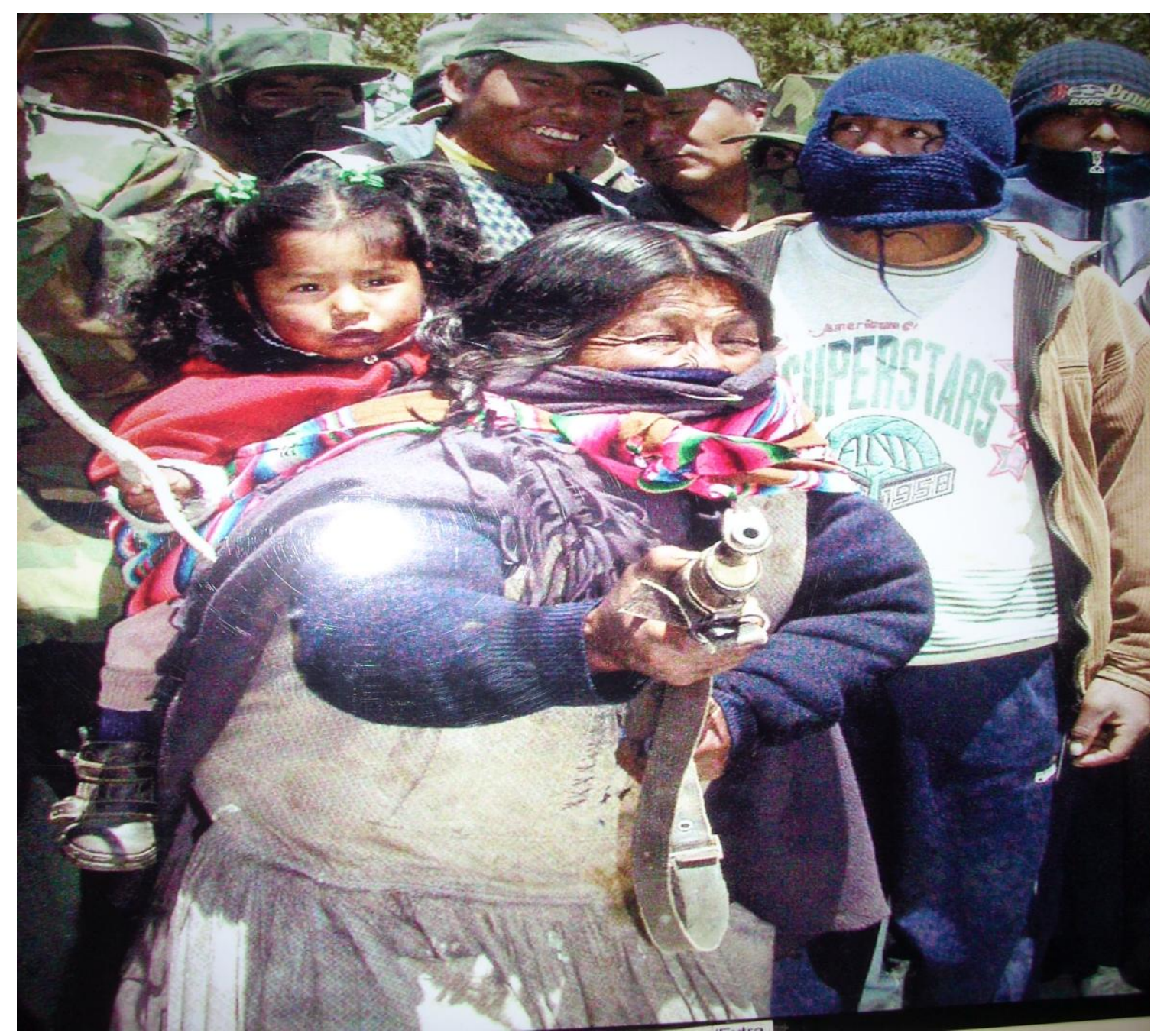

Foto 02: Guerra do Gás.

Fonte: LEONEL JÚNIOR, Gladstone. Reprodução de quadro da Federação de Trabalhadores da imprensa de La Paz. Bolívia. 2010.

A tática de luta utilizada foi a de bloqueio das diversas estradas pelo aymaras e paralisação geral em El Alto pleiteando a recuperação do gás para o povo boliviano. Ademais, queriam a saída do presidente, a revogação do decreto de hidrocarbonetos (Decreto 27.209/03) e a não repressão aos grupos sociais mobilizados. 


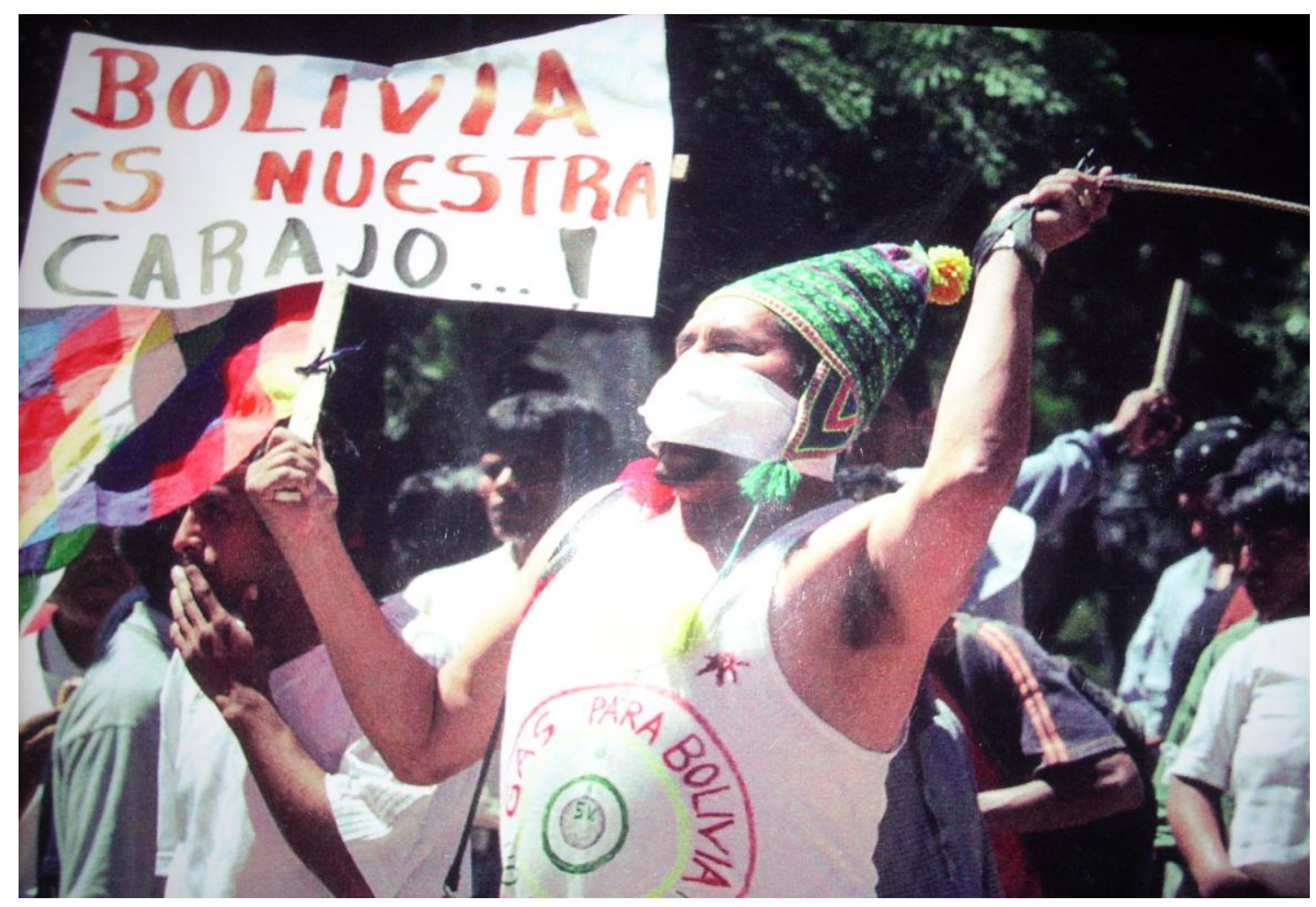

Foto 03: Guerra do Gás.

Fonte: LEONEL JÚNIOR, Gladstone. Reprodução de quadro da Federação de Trabalhadores da imprensa de La Paz. Bolívia. 2010.

A formação do bloco histórico contra-hegemônico se fazia concreto, a partir de uma estruturação indígena-popular. O pesquisador Rodrigo Santaella, ilustra esse momento, ao constatar que a paralisação ocorrida em El Alto, gerou outros efeitos como uma marcha de mineiros de Huanuni à La Paz, que "representou também um reencontro, nas estradas e na luta, de mineiros com indígenas, mas também de ex-mineiros que trabalhavam agora informalmente em El Alto com seus ex-companheiros de trabalho" (2013, p. 73). A luta popular proporcionou que esse bloco tomasse forma, construísse unidade e mecanismos autônomos de funcionamento.

Asambleas de barrio, comunidades campesinas, de sindicato y de regantes; asambleas provinciales y regionales, asambleas departamentales y cabildos dieron lugar a una estructura jerarquizada que combinó democracia asambleística y deliberativa en cada uno de los niveles horizontales, con democracia representativa y asambleística entre los distintos niveles escalonados que permitían formar criterio público entre iguales en el ámbito local (asamblea territorial) y departamental 
(cabildo), y condensación ejecutiva de opiniones a nivel departamental (Asamblea de representantes locales, Portavoces de la Coordinadora). (GARCIA LINERA, 2008, p. 305)

Essa formação popular em bloco gerou uma retaliação violenta do Estado ocasionando a morte de muitas pessoas, algo que desgastou a figura do governo e, consequentemente, do presidente. Ao logo desse conflito foi gestada a Agenda de Outubro, onde se construiu uma plataforma de reivindicações dos movimentos sociais articulados como a nacionalização dos recursos naturais e, na sequência a própria realização de uma Assembleia Constituinte.

Devido às forças das mobilizações Sanchez de Lozada foge do país, renunciando à presidência, a qual seria ocupada por Carlos Mesa, que inicia algumas reformas políticas. Dentre as medidas, o presidente emite o decreto 27.237 que garante anistia a todos os sujeitos políticos ligados aos movimentos, participantes das mobilizações de 2003, entre eles, o líder cocalero e deputado Evo Morales.

1.4.4.1.3. Mais mobilizações, o diagnóstico e o efeito das lutas populares com a eleição de Evo Morales.

A instabilidade política é retomada e as lutas reaparecem em 2005, diante da recusa de Carlos Mesa em aprovar a nacionalização dos hidrocarbonetos. As Juntas de Vizinhos (FEJUVE) em El Alto, a COB, a CSTUCB, entre outros voltam às mobilizações, que também ocorrem nas mediações de Sucre e Santa Cruz de la Sierra, sobretudo com os bloqueios de estradas. 
O interessante é que boa parte dos sujeitos que se organizaram nessas lutas, desde o ano 2000, vivem em forma comunitária, o que foi fundamental para garantirem a autonomia e a manutenção das mobilizações por longos períodos. A forma organizativa potencializou a resistência desses povos, visto que, independem, em certa medida, da dinâmica do mercado para produzirem materialmente e reproduzirem-se socialmente. O controle do tempo dos conflitos está submetido às possibilidades que dispõem a economia comunal.

\begin{abstract}
Sistema comunal productivo aplicado a la guerra de movimientos. La posibilidad de que tanta gente pueda mantenerse por tantos días en las carreteras se sostuvo por el sistema de "turnos", mediante el cual cada veinticuatro horas la gente movilizada de una comunidad es sustituida por la de otra comunidad a fin de permitir que la primera descanse, se dedique durante unos días a sus faenas agrícolas y regrese nuevamente a la movilización cuando le toque su turno para desplazarse. De ahí el cálculo conservador de que sólo en el altiplano se movilizaron cerca de quinientos mil comunarios. (GARCIA LINERA, 2008, p. 321)
\end{abstract}

Garcia Linera traz em seu argumento, o fato de não existir uma subordinação automática e hegemonia única do capital nas comunidades andinas. Ocorre somente um controle relativo sobre o processo de trabalho. Ademais, o grau de coesão dessas comunidades aumenta nesse período de crise, o que favorece o próprio desenvolvimento da dinâmica de vida ali implantada. Da mesma forma, a articulação entre elas é mais constante e entre os indígenas-camponeses, moradores dos ayllus, e os outros sindicatos de trabalhadores, juntas de vizinhos e associações, dando consistência ao bloco histórico indígena-popular.

Ahí está, en primer lugar, el uso del idioma aimara o quechua para tejer públicamente, en medios de comunicación, en asambleas y diálogos, el tejido, la intensidad, la amplitud y los pasos del levantamiento. En segundo lugar, el conocimiento comunal del territorio, de sus rutas, de su importancia, de los modos de cubrirlo y de usarlo en su favor. En tercer lugar, el 
uso de sistemas de deliberación asambleística que creó un sistema de consulta y ejecución colectiva a gran escala. En cuarto lugar, la lógica de una economía comunal con alto grado de auto-sustentabilidad que permitió controlar el tiempo de guerra en función de los dilatados ciclos de siembra-cosecha y de quebrar la sustentabilidad de los tiempos de producciónconsumo mercantil-capitalista. (GARCIA LINERA, 2008, p. 326).

Essa forma organizativa e de luta foi fundamental para a debilidade das políticas neoliberais e a resistência das comunidades a essa ação do Estado, inclusive a repressora. Em 2005, as marchas e bloqueios já estavam presentes em todas as estradas e ocorriam concentrações de pessoas, como a de San Francisco, maior já registrada no país com 300 mil pessoas no dia 07 de junho. $\mathrm{E}$ as demandas pela nacionalização dos hidrocarbonetos e pela Assembleia Constituinte eram cada vez mais fortes. (SANTAELLA GONÇALVES, 2013, p. 75-76). Mesmo que os partidos e organizações da ordem vislumbrassem formas de manter a hegemonia a partir das políticas neoliberais, as forças populares não aceitavam mais as políticas de contensão. O bloco histórico da classe dominante ${ }^{71}$ era instável e estava desgastado ${ }^{72}$. Durante esse período, segundo o intelectual e constituinte Raul Prada, o MAS-IPSP - Movimento ao Socialismo - Instrumento Político de Soberania dos Povos - que era o partido da oposição naquele momento e agregava uma parte dos sujeitos que estavam em luta, sobretudo os sindicatos agrários, ao contrário da maioria das organizações populares, era contra fechar o parlamento e favorável à continuidade do regime de democracia representativa (2005, p. 176). Contudo, cabe sopesar, a despeito da posição de Prada, que aquele momento o MASIPSP tinha um projeto mais consistente na deflagração da crise que qualquer

\footnotetext{
${ }^{71} \mathrm{O}$ único movimento que claramente apoiava o bloco dominante eram os Comitês Cívicos autonomistas, sobretudo, o de Santa Cruz de la Sierra, que compreendia os setores empresariais e agropecuários.

72 “(...) a fração financeira do capital monopolista teria perdido a predominância política que possuía durante o período anterior. Além dessa fração, o bloco no poder do período anterior seria composto também por frações "nativas", também monopolistas, do capital mineiro, do capital agroindustrial e do capital bancário "nacional". (...) o quadro de crise de hegemonia no interior do bloco no poder é muito instável, favorece a tendência da burocracia de Estado, liderada pela pequena burguesia e pelas camadas médias, a se constituir como força social, organizar as classes dominantes e conduzir a formação social boliviana a um processo de desenvolvimento capitalista com forte viés reformista." (GOMES E SOUZA, 2009, p. 7).
} 
outra organização progressista. Não havia um projeto alternativo diferenciado e concreto. $\mathrm{O}$ aprofundamento das contradições da democracia representativa poderia ser benéfico para o avanço das pautas populares ou caso nada fosse apresentado como alternativa, as pautas poderiam se desgastar com o tempo e o sistema de poder ser reapropriado pela elite burguesa. Assim, a constituinte seria um instrumento fundamental para reorganização da sociedade a partir do bloco histórico indígena-popular.

A amplitude dos protestos, em junho de 2005, levam à renúncia do presidente Carlos Mesa, seguida do presidente do Congresso, na época (Hormando Vaca Díez), e do então presidente da Câmara dos Deputados (Mario Cossio), que assumiriam na sequência. O presidente da Suprema Corte (Rodríguez Veltzé) assume também o Poder Executivo e convoca novas eleições para dezembro de 2005.

No fim de 2005, o MAS-IPSP consagra-se como partido mais votado, vencendo as eleições. Evo Morales é eleito de forma direta ${ }^{73}$ com mais de $54 \%$ dos votos. Toda a esperança de transformação da sociedade, depois de todas as lutas travadas, foi direcionada àquele resultado político. Por outro lado, 0 desafio de realizar as transformações necessárias, desde uma estrutura ainda liberal, amparado na democracia representativa, seria um grande desafio.

Para iniciar esse desafio e respeitar o anseio do vitorioso bloco indígena-popular, duas coisas deveriam ser realizadas antes de qualquer outra: a nacionalização dos hidrocarbonetos e a convocatória para uma Assembleia Constituinte.

O interessante é que esse bloco subalterno indígena-popular, por mais que começasse a hegemonizar-se na sociedade, não apresentava uma vanguarda clara, mas várias frentes de liderança. Havia uma estratégia de lutas compartilhadas, com duas vertentes distintas dentro do bloco: uma mais autonomista indígena e outra ligada ao fortalecimento do Estado em um

\footnotetext{
73 Antes da eleição de Evo em 2005, os presidentes foram eleitos indiretamente pelo Parlamento, por não alcançarem o mínimo de $50 \%$ dos votos, o que era previsto na Constituição vigente da época.
} 
momento inicial (IAMAMOTO, 2011, p. 80). O MAS-IPSP acaba sendo o instrumento que canaliza os anseios desse bloco e transforma as revoltas em uma vitória eleitoral. $O$ que não quer dizer que o partido tomou a frente como direção do bloco, que funcionava a partir desse caráter mais plural dos grupos que o compunham. Contudo, o bloco se manteve mesmo com a vitória de Evo Morales e convencionou formar o que ficou conhecido como Pacto de Unidade aliando os trabalhadores/as, movimentos indígenas e camponeses na árdua tarefa de garantirem a realização da constituinte e a promulgação da nova Constituição. O uso contra-hegemônico dos instrumentos políticos hegemônicos é algo inovador, e se repete na história recente dos países latinoamericanos, conforme ocorreu também na Venezuela, destaca Boaventura de Sousa Santos.

La tercera dimensión del contexto latinoamericano es que en este continente, más que en ningún otro, se ha logrado en los últimos veinte años hacer con éxito un uso contra hegemónico de instrumentos políticos hegemónicos como son la democracia representativa, el derecho, los derechos humanos y el constitucionalismo. Entiendo por instrumentos hegemónicos las instituciones desarrolladas en Europa a partir del siglo XVIII por la teoría política liberal con vista a garantizar la legitimidad y gobernabilidad del Estado de Derecho moderno en las sociedades capitalistas emergentes. Se trata de instrumentos hegemónicos porque fueron diseñados para garantizar la reproducción ampliada de las sociedades capitalistas de clases (...) $(2010$, p. 59$)$.

1.4.4.2. A nacionalização dos hidrocarbonetos e a demanda pela constituinte.

Em Maio de 2006, o governo anuncia o decreto de nacionalização dos hidrocarbonetos (Decreto Supremo 28.701). O decreto previa além da nacionalização dos recursos naturais de hidrocarbonetos, que a produção de 
outras empresas em território boliviano fosse direcionada à YPFB Yacimientos Petroliferos Fiscales Bolivianos -, nacionalizando, inclusive as ações para que a YPFB tivesse mais de $50 \%$ dessas produtoras de petróleo em território boliviano.

O novo bloco no poder se estabelece contando com diversas organizações sociais responsáveis por direcionar as políticas públicas formuladas pelo governo, tendo representantes desses setores nas esferas institucionais do Executivo e na maioria parlamentar para impulsionar as mudanças de projeto político.

Nos primeiros anos do governo Evo era notória a intenção de fortalecimento dos setores mais empobrecidos da sociedade e também do Estado, pobre e frágil estruturalmente ${ }^{74}$. Assim, essa vertente era priorizada nesses momentos iniciais, já o debate sobre as autonomias indígenas ainda "engatinhava". Para o governo, a reversão às perdas do período neoliberal deveria ser imediata e para isso era necessário o fortalecimento do Estado. Alguns dados desses anos iniciais comprovaram isso.

A diferencia de lo que ocurrió en todo el periodo neoliberal, en
estos dos últimos años, la principal fuente de inversión en el
país ha sido el Estado que ha duplicado su presencia, pasando
de 550 millones de dólares en 2005 a 1.100 millones de
dólares en 2007 y aproximadamente, a más de 1.600 en 2008 ,
lo que está permitiendo cumplir programas sociales vitales para
reducir la pobreza y también cumplir una política expansiva de
inversión productiva que permita crear una base industrial
mínima para un crecimiento económico sostenible. Hoy, con la
inversión estatal se está comenzando a industrializar el gas
(planta de GLP en Campo Grande, planta separadora de gas
en el Chaco, Termoeléctrica en el Chapare), se están
relanzando actividades mineras metalúrgicas (Huanuni, Vinto,
Coro Coro, colas y desmontes, etc.), se está apoyando a los
pequeños productores vinculados al mercado interno a través
de la Empresa Estatal de Apoyo a la Producción Agrícola
(EMAPA) a fin de garantizar la soberanía alimentaria del país, y

\footnotetext{
74 "La mayoría de las políticas públicas están destinadas al campo o, aun siendo universales, tienen más impacto en estas regiones por sus niveles de pobreza y de abandono estatal, como los bonos sociales, los planes de alfabetización, la construcción de caminos y carreteras, los proyectos de electrificación rural y extensión de internet y telefonía celular, etc." (DO ALTO, 2011, p. 108-109).
} 
se están creando fábricas para abastecer el mercado interno (de papel, cartón y otros). (...) El Estado hoy es el principal "empresario colectivo" pasando a participar del 0,8 por ciento de la generación productiva de riqueza en 2005, al 7 por ciento en 2007; en tanto que su participación en la totalidad del PIB ha subido de 15 por ciento al 22 por ciento en tan sólo dos años. (GARCIA LINERA, 2008, p. 404)

A intenção do governo era redirecionar o excedente econômico, produzido a partir da retomada dos setores estratégicos, para o Estado. Assim, os investimentos nos setores sociais mais vulneráveis e no setor produtivo nacional seriam mais facilmente viabilizados. Isso foi o que o Vice-presidente Álvaro Garcia Linera concebeu como uma tática necessária que denominou de "capitalismo andino-amazônico" (2006). A ideia seria avançar nessa espécie de modus operandi capitalista concomitantemente com o fortalecimento das economias comunitárias não capitalistas para se chegar a um novo modelo depois de um tempo.

O bloco indígena-popular, diante disso, iniciava uma tentativa de superação das suas contradições internas e propunha uma reestruturação do Estado, já em andamento com os primeiros anos do governo. A Assembleia Constituinte era a medida necessária que teria a capacidade de aprofundar as transformações almejadas.

O antigo bloco de poder, debilitado com a derrota eleitoral, tentaria outras formas de desestabilização do governo, mantendo fortes resistências regionais e locais sustentadas pelo histórico poder das elites. No entanto, eles estavam fora do poder político central. As formas de enfrentamento entre os blocos antagônicos ocorreriam em outros âmbitos, inclusive no debate da constituinte. A questão que daria centralidade a esse antagonismo ainda é a unidade popular frente à investida contínua das forças imperialista e da elite interna formadora do antigo bloco do poder.

Uma das formas de desestabilização foi a tentativa frustrante de revogar o mandato de Evo Morales em 2008. O referendo revogatório ocorreu 
em Agosto e o presidente foi ratificado no cargo com $67 \%$ da votação favorável.

Em setembro de 2008, o bloco histórico da direita inicia algumas ações golpistas contra o Governo Central, como ocupação e destruição de algumas instituições do Estado. Mais de 72 instalações governamentais foram queimadas como: canal de televisão, rádio estatal, escritório da empresa de telecomunicações, sabotagem de gasoduto em Tarija e por fim, o mais grave, que foi o massacre de dirigentes camponeses no Departamento de Pando. Mais um golpe de Estado estava em andamento na Bolívia com ações ilegítimas, além de terem um caráter marcadamente fascista, racista e antidemocrático (GARCIA LINERA, 2012a, p. 20). Diante dessas ações, o governo interviu militarmente em Pando, expulsou o embaixador dos Estados Unidos $^{75}$, que articulava internacionalmente as ações, e iniciou uma mobilização da sociedade civil nos redutos mais fortes da direita golpista.

Esse é o momento concebido historicamente por Garcia Linera como "ponto de bifurcação", que ocorreu até outubro de 2008.

Se trata del momento en que los bloques antagónicos, los proyectos irreconciliables de sociedad que cubren territorialmente la sociedad y el Estado, deben dirimir su existencia de manera abierta, desnuda, a través de la medición de fuerzas, la confrontación (el último recurso que resuelve las luchas cuando no hay ya posibilidades de otra salida). (2012a, p. 19)

As ações do bloco histórico indígena-popular, que controlava o aparato Estatal, aliado às Forças armadas, e construía hegemonia ${ }^{76}$ na sociedade civil,

\footnotetext{
75 "Si vemos el otro bloque socio-económico y politico, también se observa que el proyecto político no está articulado por los partidos. En parte está articulado por el núcleo corporativo duro ampliado, que son los comités cívicos y por su fuerte articulación con poderes políticos y económicos externos. Una buena parte de la articulación fue promovida por la embajada norteamericana. Esto significa que por ambos lados, aunque no con el mismo peso, la articulación de proyecto político está en los núcleos más clasistas”. (TAPIA, 2010, p. 120).

${ }^{76}$ Para Luis Tapia, não era o momento de afirmar que o bloco indígena-popular era um bloco dominante por não ter o potencial ainda de controlar a economia. "Estamos en una situación en la que, por un lado, tenemos un bloque político que está configurado en torno a un partido de origen campesino que ha articulado una amplia red de alianzas políticas con varios sectores
} 
foram suficientes para que os golpistas retrocedessem. A consolidação do bloco se daria com a reeleição de Evo em 2009.

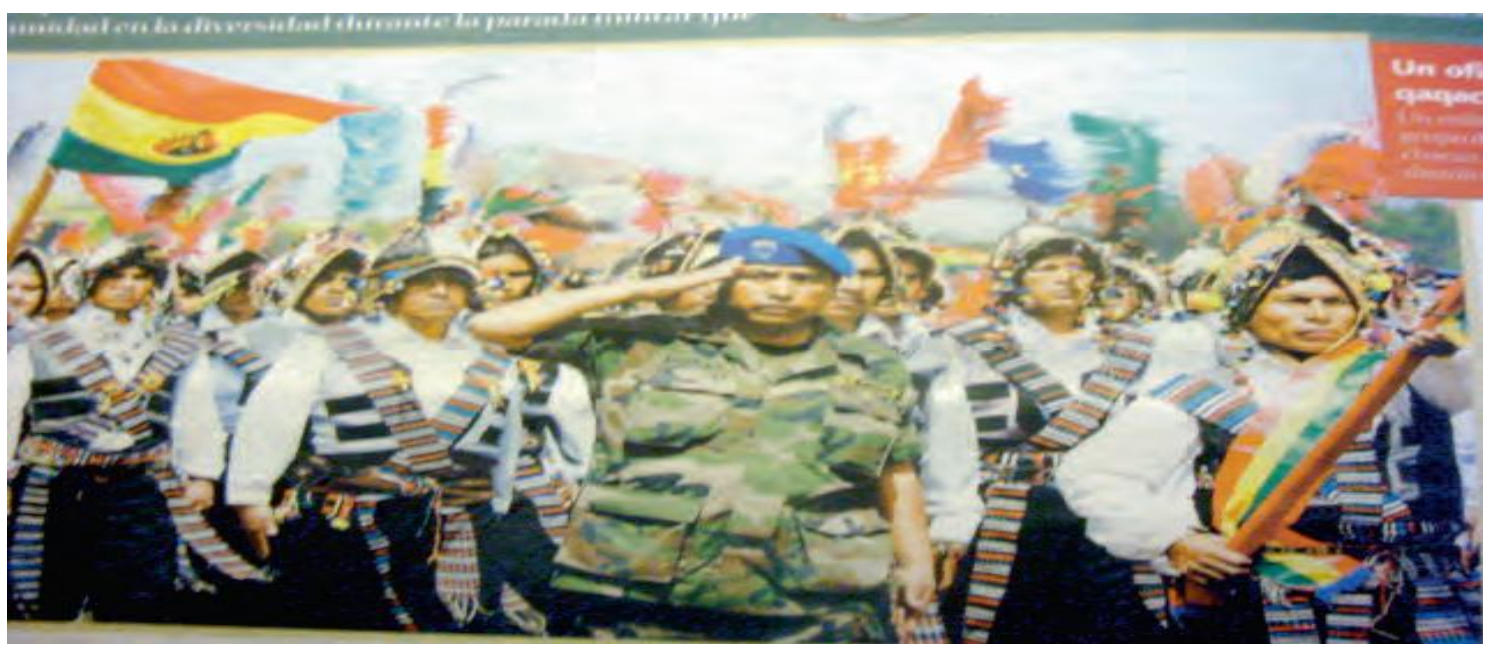

Foto 04 - 0 efetivo das Forças Armadas e os representantes dos povos indígenas em demonstração de unidade em Santa Cruz de la Sierra.

Fonte: (HEMEROTECA, 2007)

Antes da vitória eleitoral no ano de 2009, era importante a promulgação da Constituição para a reestruturação do Estado nos moldes que garantissem os avanços descolonizadores e democráticos do bloco vitorioso. Precisamente "esta é a função do direito no Estado e na sociedade; através do "direito" o Estado faz "homogéneo" o grupo dominante e tende a criar um conformismo social que seja útil a linha de desenvolvimento do grupo dirigente." (tradução livre) (GRAMSCI, 1984, p. 70-71).

Após essa análise do contexto sócio-político boliviano pré-Constituição de 2009, caberá justamente tratar do papel do Direito e da nova Constituição, apresentado nesse novo cenário político.

En Bolivia el llamado a refundar el país desde las naciones y pueblos que la constituyen con una Asamblea Constituyente es la alternativa política o la oportunidad histórica de construir una transición para una institucionalidad y legalidad más plural y,

populares, pero que no constituye un nuevo bloque dominante, ya que no controla la economía, pero está en proceso de avanzar para crear las condiciones de un mayor control en el ámbito de los recursos naturales. Por el otro lado, tenemos una clase burguesa y terrateniente todavía dominante que ha perdido la dirección nacional del estado y el predominio en el sistema de partidos nacional, aunque todavía lo mantiene en algunos departamentos. (...). Esa sería la condición más general en lo que concierne a la relación entre composición de clase y la configuración de un bloque político dominante en el país" (2009b, p. 35). 
por ende, democrática. Esta demanda por la realización de la Asamblea Constituyente es conjuntamente con la demanda de una nacionalización de los hidrocarburos, es armar un nuevo escenario para replantear la Constitución Política del Estado y hacer un acto de soberanía nacional. Es decir, un reposicionamiento conjunto de la forma de inserción en el orden económico internacional y de tener la capacidad de crear un nuevo orden estatal. Por lo tanto, soberanía, dignidad y pluralidad son los principios articuladores de un sentido común de los movimientos sociales e indígenas que definen la urgencia de construir un núcleo común para establecer un nuevo rol y estructura del Estado. (CAMACHO, 2007, p. 12). 


\title{
CAPÍTULO 2 - A CRÍTICA À CONSTRUÇÃO LIBERAL DO DIREITO E O NOVO CONSTITUCIONALISMO LATINO-AMERICANO: A EXPERIÊNCIA DA CONSTITUIÇÃO POLÍTICA DO ESTADO PLURINACIONAL DA BOLÍVIA
}

\begin{abstract}
"No dia de hoje do ano 2009, um plebiscito popular disse sim à nova constituição proposta pelo Presidente Evo Morales. Até este dia, os índios não eram filhos da Bolívia: eram sua mão de obra, e só. Em 1825, a primeira Constituição outorgou a cidadania a 3 ou 4\% da população. Os demais - índios, mulheres, pobres, analfabetos - não foram convidados para a festa. Para muitos jornalistas estrangeiros, a Bolívia é um país ingovernável, incompreensível, intratável, inviável. São os que se enganaram de in: deveriam confessar que a Bolívia, para eles, é um país invisível. E não há nada de estranho nisso, porque até o dia de hoje, também a Bolívia foi um país cego de si." (2012, p. 40).

EDUARDO GALEANO. 26 de Janeiro, Os Filhos dos Dias.
\end{abstract}

2.1. O paradigma político do direito como fundamento do constitucionalismo moderno e das teorias jurídicas hegemônicas.

Existe no mundo jurídico, sobretudo na academia, um grande debate acerca do papel do direito na sociedade. Até que ponto os direitos fundamentais, expostos nas Constituições modernas, são garantidos para as pessoas e para os grupos? Quais os caminhos possíveis de serem trilhados para além dessas previsões constitucionais? Por vezes, o direito passa uma imagem de instrumento mantenedor das instituições, enquanto a realidade social clama por dinamismos e transformações. De fato, o direito cumpre esse papel conservador em muitas situações, o que gera uma descrença dos 
setores mais progressistas com relação ao potencial do direito em servir como instrumento de mudança. A análise do direito deve levar em consideração a totalidade das relações sociais em que está inserido, a partir de determinada historicidade, e não ser simplesmente reproduzido como se fosse mera norma jurídica, decisão judicial ou procedimento argumentativo. Até porque, as relações jurídicas não estão isoladas, mas atreladas a um contexto político e, sobretudo, às relações econômicas estabelecidas (MARX, 2012b, p. 27).

O direito e as instituições legitimadas por ele não são eternos. Frente às constante mudanças tanto nas organizações sociais quanto no ambiente em que as circunda, toda ordem social é submetida a uma série de pressões que conduzem a alterações, substituições e supressões nas instituições que a compõem. As modernas constituições e a ideologia constitucionalista, como quaisquer outros elementos sociais, estão sujeitas a esse processo de modificação, o que justifica o fato de que alguns pensadores questionem os fundamentos do constitucionalismo moderno e se perguntem sobre os prováveis desenvolvimentos que se descortinam no horizonte dessas transformações.

Após os delineamentos conceituais propostos por Thomas Kuhn, em sua obra, "A Estrutura das Revoluções Científicas", as reflexões sobre as transformações no nosso modo de compreender passaram a utilizar largamente a noção de "paradigma"77. Kuhn sustenta que o conhecimento se dá dentro de modelos gerais de compreensão (chamados por ele de paradigmas), que nos oferece as categorias básicas com as quais elaboramos as teorias que explicam a realidade, e que é preciso avaliar de forma diversa os processos de desenvolvimento dos saberes que ocorrem no interior desses modelos, dos processos de ruptura em que se questiona a validade do próprio modelo. Boaventura de Sousa Santos (2002) está entre os autores que se

\footnotetext{
${ }^{77}$ A noção de paradigma é útil na medida em que distingue modelo de macromodelos. A crise dos macromodelos se dá quando os modelos baseados nele perdem capacidade explicativa. No caso analisado não há uma crise explícita nos macromodelos, mas nos modelos. As categorias normativas básicas permanecem mesmo que trabalhada de maneira distinta como: soberania popular, governo limitado, governos representativos, divisão de poderes. Até certo ponto, o macromodelo permanece e o que se discute é qual é o melhor modelo para a sua realização.
} 
utilizam da estrutura conceitual de Kuhn para afirmar que existe no direito um paradigma dominante e, com isso, permitir a identificação de certas críticas como desafios a esse paradigma. A percepção de que essas críticas se avolumam permitiu que Santos denominasse de "crise paradigmática" a atual situação em que as críticas ao paradigma dominante apontam para um processo de transição paradigmática ${ }^{78}$ e indicando que somente através da sucessão de lutas e com uma maior descrença sistêmica, aprofundar-se-á a crise do paradigma dominante, mesmo sem contar com a emergência de um novo paradigma ainda vigente.

Outros autores se apropriam das noções de Kuhn para identificar na base do conhecimento moderno um paradigma que privilegia categorias ligadas a uma determinada vivência histórica centrada na experiência europeia e estadunidense e que não é capaz de explicar devidamente outros contextos sociais. Nesse grupo, destaca-se o pensador Enrique Dussel que se dedica a elaborar uma estrutura conceitual capaz de abordar as questões sociais desde uma perspectiva latino-americana. Este é um grande desafio, pois as construções paradigmáticas do direito foram concebidas e são desenvolvidas a partir de uma cultura jurídica incapaz de orientar uma reflexão apropriada da realidade peculiar e popular da América Latina. A presente pesquisa busca enfrentar esse desafio, visto que ele parte do diagnóstico de insuficiência do paradigma político do direito, em que se baseia o constitucionalismo moderno, a partir da perspectiva liberal hegemônica, herança da modernidade europeia que aportou neste continente. A adoção desse paradigma conduziu à instituição de construções constitucionais e teorias jurídicas contemporâneas

78 "Tenho vindo a defender que estamos a entrar num período de transição paradigmática. Resumo aqui o argumento já conhecido porque parto dele para avançar na formulação da natureza da transição paradigmática apresentada nesta parte. O paradigma sócio-cultural da modemidade, constituído antes de o capitalismo se ter convertido no modo de produção industrial dominante, desaparecerá provavelmente antes de o capitalismo perder a sua posição dominante. Esse desaparecimento é um fenómeno complexo, já que é simultaneamente um processo de superação e um processo de obsolescência. É superação na medida em que a modernidade cumpriu algumas das suas promessas, nalguns casos até em excesso. É obsolescência na medida em que a modernidade já não consegue cumprir outras das suas promessas. Tanto o excesso como o défice de cumprimento das promessas históricas explicam a nossa situação presente, que aparece, à superfície, como um período de crise, mas que, a nível mais profundo, é um período de transição paradigmática. Como todas as transições são simultaneamente semi-invisíveis e semicegas, é impossível nomear com exactidão a situação actual". (SOUSA SANTOS, 2002, p. 49). 
insuficientes para organizar a política e o direito da América Latina, motivo pelo qual existe hoje um movimento de construção de novas abordagens.

Mesmo que um novo paradigma ainda não se apresente no horizonte, é uma tarefa do jurista comprometido com o povo refletir sobre os efeitos do paradigma atual na sociedade e as possibilidades do desabrochar desse novo elemento. Ademais, "o paradigma, ou modelo de um sistema político, não é um projeto político concreto no curto prazo" (DUSSEL, 2007, p. 136). Deve ser trabalhado e repensado com base nas necessidades e realidade do seu povo.

Esta será a tarefa que os juristas deverão cumprir neste período histórico, sob o risco de continuarem analisando o direito de maneira dissonante à dinâmica social.

2.1.1 A análise geral dos paradigmas a partir do estudo de Thomas Kuhn e os seus desdobramentos no mundo do direito

Para enfrentar o debate paradigmático, sobretudo no direito, as contribuições que o físico estadunidense Thomas Kuhn traz são essenciais. $O$ autor trabalha com alguns conceitos importantes para a própria dinâmica de desenvolvimento científico.

A abordagem feita do paradigma ${ }^{79}$ parte de uma perspectiva históricosociológica da ciência onde se busca legitimar a aceitação de uma macroteoria perante a comunidade científica. De acordo com Kuhn, o período em que as atividades científicas serão trabalhadas, a partir do paradigma posto é considerado o momento da prática da "ciência normal". Esta, no decorrer do

\footnotetext{
79 "Considero "paradigmas" as realizações científicas universalmente reconhecidas que, durante algum tempo, fornecem problemas e soluções modelares para uma comunidade de praticantes de uma ciência." (KUHN, 1998, p. 13).
} 
tempo, desgasta-se e demonstra a incapacidade de solucionar determinadas questões emergentes na sociedade, assim abre-se a possibilidade da ocorrência da "Revolução Científica". Nesta, há uma emergência de um novo paradigma em substituição ao paradigma posto, renovando-se um ciclo que se restabelecerá com novas bases e na formação de um novo período de ciência normal.

Certamente, todas essas perspectivas de transformação não ocorrem isoladamente, a partir de uma demanda de mudanças nos rumos da ciência. Junto com elas, transformações sociais e políticas provavelmente emergirão no âmago da sociedade, por mais que Kuhn indique categoricamente apenas as mudanças dentro do campo da ciência.

"Os paradigmas definem o campo do saber científico, modelando o objeto da investigação, bem como os procedimentos metodológicos." (MACHADO, 2011, p. 23). Com isso, o seu desenvolvimento científico atende a certos interesses de grupos específicos da sociedade. $O$ mito da neutralidade não prevalece nesse contexto paradigmático, onde cabe aos estudiosos entenderem e desvendarem as motivações para 0 desenvolvimento de determinadas teorias científicas específicas. Mesmo porque algumas teorias são suprimidas, ou não seguem adiante, devido ao paradigma hegemônico estabelecido. Essas críticas apresentadas atacam a consequência política do sistema, Kuhn ataca também a consistência do sistema em si.

De acordo com Kuhn, uma tarefa colocada é a seguinte:

De um lado deve determinar quando e por quem cada fato, teoria ou lei científica contemporânea foi descoberta ou inventada. De outro lado, deve descrever e explicar os amontoados de erros, mitos, e superstições que inibiram a acumulação mais rápida dos elementos constituintes do moderno texto científico (1998, p. 20).

Em determinados casos, o próprio desenvolvimento científico é paralisado, inviabilizando também um maior desenvolvimento das forças 
produtivas, a fim de atender alguns interesses que suportam o paradigma estabelecido. A criação das patentes permite essa situação, uma vez que garante o monopólio de desenvolvimento científico de alguma invenção a alguma empresa, por exemplo, que poderá desenvolver ou não determinados produtos tendo em vista os próprios interesses e não os interesses sociais envolvidos.

Em um curso ministrado pelo professor José Paulo Netto, em 2002, sobre metodologia marxista, ele exemplifica que já na década de 50, a General Motors comprou a patente para que ninguém produzisse o motor à explosão circular, pois as taxas de lucro que eles operavam não justificariam este desenvolvimento. Da mesma forma, a pilha da General Electric rendia aproximadamente 20 horas e poderia render 3 vezes mais tempo. Ao comprarem a patente, a empresa inviabilizou o desenvolvimento das forças produtivas, nesse caso, de uma pilha mais potente, para a manutenção da sua taxa de lucro (NETTO, 2002).

Nestes exemplos, a perspectiva de um possível rompimento com os compromissos básicos da "ciência normal" estabelecida foram suficientes para o não prosseguimento e implementação dos avanços científicos ${ }^{80}$. Isso demonstra um suporte paradigmático, a partir da necessidade de preservação do capitalismo e dos seus valores. Dessa forma, atrelam-se compromissos científicos ao paradigma estabelecido. Para Fals Borda;

[...] não pode haver valores absolutos no conhecimento científico porque este irá variar conforme os interesses objetivos das classes envolvidas na formação e na acumulação de conhecimento, ou seja, na sua produção [...] Além do mais esta comunidade científica ocidental exerce uma nítida influência sobre a manutenção do status quo político e econômico que cerca o sistema industrial capitalista dominante. Sob essas condições, evidentemente, a produção de conhecimento nesse nível acha-se orientada para a preservação e fortalecimento do sistema. (1983, p. 44).

80 "(...) a ciência normal frequentemente suprime novidades fundamentais, porque estas subvertem necessariamente seus compromissos básicos." (KUHN, 1998, p. 24). 
No entanto, em um momento de crise mundial - não só econômica, mas também política, social e de valores - impulsionado pela forma de desenvolvimento do capitalismo, os povos vitimados por este sistema iniciam uma luta para o estabelecimento de novos paradigmas. Somam-se à luta de povos que formam a periferia política e econômica do sistema-mundo, como os latino-americanos, os quais também foram submetidos aos paradigmas hegemônicos e pretensamente universais.

\begin{abstract}
As revoluções políticas iniciam-se com um sentimento crescente, com frequência restrito a um segmento da comunidade política, de que as instituições existentes deixaram de responder adequadamente aos problemas postos por um meio que ajudaram em parte a criar. De forma muito semelhante, as revoluções científicas iniciam-se com um sentimento crescente, também seguidamente restrito a uma pequena subdivisão da comunidade científica, de que 0 paradigma existente deixou de funcionar adequadamente na exploração de um aspecto da natureza, cuja exploração fora anteriormente dirigida pelo paradigma. Tanto no desenvolvimento político como no científico, o sentimento de funcionamento defeituoso, que pode levar à crise, é um prérequisito para a revolução (KUHN, 1998, p. 126).
\end{abstract}

Os grupos hegemônicos ainda tentam outras saídas para a manutenção da hegemonia constituída ao perceberem que os paradigmas estabelecidos não mais conferem respostas adequadas diante das expectativas da sociedade. Algo que Thomas Kuhn observa ao deparar-se com a possibilidade de transição paradigmática em períodos de crise.

As crises podem terminar de três maneiras. Algumas vezes a ciência normal acaba revelando-se capaz de tratar do problema que provoca crise, apesar do desespero daqueles que o viam como o fim do paradigma existente. Em outras ocasiões o problema resiste até mesmo a novas abordagens aparentemente radicais. Nesse, caso, os cientistas podem concluir que nenhuma solução para o problema poderá surgir no estado atual da área de estudo. O problema recebe então um rótulo e é posto de lado para ser resolvido por uma futura geração que disponha de instrumentos mais elaborados. Ou finalmente, o caso que mais nos interessa: uma crise pode 
terminar com a emergência de um novo candidato a paradigma e com uma subsequente batalha por sua aceitação (KUHN, 1998, p. 115-116).

O período atual nos remete à reflexão de Antonio Gramsci, quando apontava em seus escritos que o velho já morreu e o novo ainda não nasceu ${ }^{81}$. Talvez, seja uma metáfora adequada aos paradigmas científicos, políticos e filosóficos da atualidade. Esses não viabilizam, sobretudo na América Latina, a construção de uma sociedade com características próprias, em busca de uma emancipação histórica, a qual enfrenta práticas neocolonialistas ou estimuladoras de uma dinâmica apropriada a um capitalismo dependente.

Mesmo nas análises do constitucionalismo moderno e nas teorias do direito, a lógica paradigmática estabelecida reproduz efeitos semelhantes ao estabelecido em outras áreas. Estas, como qualquer outra teoria científica, estão situadas nas arestas que o paradigma hegemônico permite.

As teorias do direito possuem o objeto e o método próprio, pautados pelo paradigma científico constituído, além de serem devidamente amparadas por "paradigmas filosófico e político, pois, além da natureza do direito, a ciência jurídica deve explicar o seu fundamento de validade (legitimidade) e os seus fins (eficácia)" (MACHADO, 2011, p. 25). Assim, esses paradigmas "condicionam toda a produção teórica e dogmática da ciência jurídica, bem como a dimensão aplicada dessa ciência, definindo inclusive os fundamentos e as finalidades do direito." (ibid). Ao longo da história jurídica ocidental, os paradigmas científico, filosófico e político foram desenvolvidos ora pela corrente doutrinária proveniente do direito natural, ora pelo direito positivo. Neste parâmetro, limita-se a reflexão jurídica a partir destas duas linhas, como se o direito não pudesse ser pensado e concebido para além dessa dicotomia.

\footnotetext{
81 "Se a classe dominante perde o consenso, ou seja, não é mais 'dirigente', mas unicamente 'dominante', detentora da pura força coercitiva, isto significa exatamente que as grandes massas se destacaram das ideologias tradicionais, não acreditam mais no que antes acreditavam, etc. A crise consiste justamente no fato de que o velho morre e o novo não pode nascer: neste interregno, verificam-se os fenômenos patológicos mais variados" (GRAMSCI, 2007, p. 184).
} 
No decorrer da modernidade e com a ascensão da burguesia no comando econômico e político da sociedade, aquela fundamentação jurídica, por vezes, metafísica do direito natural cedeu lugar ao direito positivo. Este, tendo as formulações estimuladas pela Escola da Exegese na França do século XIX, equiparava o direito à lei escrita. A partir desta realidade, os paradigmas dominantes da sociedade foram desenvolvidos em suas matrizes fundantes tendo, desde então, uma linha central liberal prevalecente. O que se observa é que "o direito desenvolveu um autoconhecimento especializado e profissionalizado, que se define como científico (ciência jurídica), dando assim origem à ideologia disciplinar" a que, Boaventura de Sousa Santo chama de cientificismo jurídico (2002, p. 164-165), da qual decorre o positivismo jurídico. Hoje, mesmo com delineamentos próprios decorrentes da realidade concreta na atualidade e das variantes teóricas do direito positivo, os paradigmas ainda são sustentados por esta corrente de pensamento e construção jurídica ${ }^{82}$.

Portanto, os paradigmas científicos do juspositivismo se estabelecem da seguinte forma: a lei escrita é o objeto da ciência jurídica; o método gramatical é o único caminho para a obtenção do conhecimento jurídico. O paradigma filosófico do juspositivismo, dado o formalismo abstrato do objeto da ciência do direito, pois a lei é um conjunto de formalidades abstratas, segue sendo a matriz racionalista (platônica-cartesianakantiana) e faz repousar a validade e legitimidade do direito na vontade estatal. O paradigma político explica a eficácia e os fins do direito, obviamente, com base nos valores liberais, isto é, os valores que também definem a eficácia e as finalidades do estado moderno, colocando a manutenção da ordem burguesa como objetivo ou fim supremo (MACHADO, 2011, p. 26).

Diante de um questionamento do constitucionalismo moderno e das teorias jurídicas ainda hegemônicas, neste momento nos interessa refletir e questionar este paradigma político do direito à luz da realidade latinoamericana.

\footnotetext{
82 "Os juristas não tem, hoje, muito boa reputação, na comunidade científica. Isto é, em grande parte, devido a eles mesmos, que mantêm a visão castradora do Direito e dão à "ciência jurídica" o ar duma conversa de eunucos, guardando as normas, como se fossem odaliscas do grande paxá estatal." (LYRA FILHO, 1986, p. 313).
} 
2.1.2. Crítica à modernidade e ao paradigma jurídico hegemônico diante da realidade da América Latina: a necessidade de uma concepção transmoderna e transontológica do direito

Repensar o paradigma político do direito e os processos constitucionais a partir da realidade latino-americana requer muito mais que remeter a uma análise jurídica histórica, mas exige repensar toda a leitura que é feita da modernidade atualmente, como já detalhado ${ }^{83}$. Pois, é a partir dela que advém toda a influência europeia para a América.

Uma visão não eurocêntrica da história mundial, conforme já pontuou Darcy Ribeiro, deve ser resgatada para avançarmos no conceito de modernidade e consequentemente na reflexão sobre a necessidade de outros paradigmas. Diferentemente da opinião de Hegel que concebia que "a história universal vai do Leste para o Oeste, pois a Europa é o fim da história universal [...]" (1999, p. 93), além de centro dessa história, a reflexão para uma análise real da América Latina deve ocorrer de outra forma. Não tendo a Europa como ente inicial da história, mas considerando formas organizativas reais, as quais acumularam para o desenvolvimento de civilizações que pouco conhecemos.

La revolución neolítica o urbana comienza hace unos 10.000 años a. C., tiene ya una expresión madura en la confederación de ciudades en la Mesopotamia (en el cuarto milenio a. C.), y podemos situarla en el tercer milenio a. C. en las primeras dinastías egipcias (que provenían del sur, del mundo bantú del África central, y donde comienza la larga tradición de la "resurrección" que culminará en los cultos de Osiris); continuará en las ciudades del valle del Indo (a mediados del tercer milenio), para culminar por el este en el Imperio chino (cuyas primeras dinastías deben situarse a comienzo del segundo milenio). Fue una larga marcha hacia el este (contra la opinión de Hegel de que la historia tiene la dirección "del este hacia el

${ }^{83}$ Ver Capítulo 1, ponto 1.2.1 
oeste". Lo que se permite decir que "Europa es el centro y el fin de la historia"). (...) Hace unos 40000 años a.C., el Homo sapiens cruza por Bering y llega por Alaska y Canadá al continente americano. (...) Las grandes culturas mesoamericanas (olmeca, maya, tolteca en Teotihuacán, azteca, zapoteca, etc.), las culturas chibchas en Colombia, y la inca, partiendo de las culturas del Titicaca boliviano, hacia Perú y Ecuador, constituyen el progreso hacia el este de la revolución neolítico-urbana (DUSSEL, 2011, p. 24).

Enrique Dussel e Darcy Ribeiro (1983b) fazem essa constatação do desenvolvimento histórico. Pode ser verificado que a história da humanidade, contrariando os preceitos de Hegel, segue o caminho contrário, do Oeste para o Leste, configurando a Europa como mera periferia do Sistema-Mundo. Não é por acaso, que as grandes influências da Grécia são africanas e árabes ${ }^{84}$, e antes mesmo do aparecimento dos pré-socráticos, já havia um desenvolvimento teórico e cultural avançado, como a sabedoria taoísta de Confúcio, a filosofia oriental budista entre outras.

O mundo mulçumano constituía a hegemonia no sistema-mundo ${ }^{85}$ até os portugueses e espanhóis expulsarem os árabes da Europa e expandirem a política mercantil para fora da Europa, explorando matéria-prima e os povos como ocorreu na América Latina. Esses mesmos países ibéricos, que séculos depois seriam desprezados dentro da própria Europa, são os responsáveis pelo início do que é concebido como modernidade.

Juntamente com a prática colonizadora veio a dominação em suas variadas facetas. O filósofo Enrique Dussel (2011) trabalha com algumas categorias que facilitam a compreensão deste período. A dominação erótica é uma dessas manifestações que vieram com os europeus, em que vige 0 sistema patriarcal, onde o homem sobrepõe-se à mulher e aos filhos/as. $O$ machismo manifesta-se também na reprodução de costumes como a

\footnotetext{
${ }^{84}$ O egípicio Danaos, por exemplo, é o fundador de Atenas.

85 "Nesta situação, falar de uma Europa como começo, centro e fim da História Mundial - como era a opinião de Hegel - era cair numa miopia eurocêntrica. A Europa Ocidental não era o "centro", nem sua história nunca fora o centro da história." (DUSSEL, 1993, p.113).
} 
justificação do adultério masculino e no menosprezo às mulheres nativas da América, as quais eram submetidas ao julgo e poderio masculino.

Outra manifestação de dominação é a pedagógica, que era exercida a partir da repressão à cultura própria e a imposição de outros parâmetros culturais, educacionais violadores dos povos. A juventude recebia os valores dominantes como se fossem naturais e necessários de serem exercidos universalmente.

Por fim, a dominação também aparecia em decorrência da prática fetichista estimulada pelo desenvolvimento do capitalismo. Exaltando-se novos seres idolatrados, como o ouro, a prata, a moeda, etc. Configura-se uma mística em torno do "deus" dinheiro dando "vida" ao mercado. (DUSSEL, 2011)

Para conceber e reformular novas questões, a nossa história deve ser repensada e as críticas decorrentes da modernidade apontadas. Assim, existiriam condições objetivas mais claras para repensar, inclusive os paradigmas políticos do direito na América Latina. Antes dessa reflexão, a "transmodernidade" poderá forjar-se como uma saída à modernidade hegemônica e dominadora, onde os grupos que estavam relegados à exterioridade sistêmica possuem papel preponderante na formação social. Dussel esclarece a importância desse conceito:

\footnotetext{
Deve ser um projeto "transmoderno" (e seria então uma "transmodernidade" por subsunção real do caráter emancipador racional da Modernidade e de sua Alteridade negada ("o Outro" e não a Modernidade), por negação de seu caráter mítico que justifica a inocência da Modernidade sobre suas vítimas e por isso se torna contraditoriamente irracional). (1993, p.187).
}

Da mesma forma que a modernidade hegemônica concebida a partir da totalidade do sistema-mundo, onde a Europa está no centro irradiador, o direito e o constitucionalismo nascem com características que reproduzem esta lógica. Logo, toda a construção liberal até hoje estimulada, a qual sustenta um 
paradigma político e, com isso um modelo constitucional liberal do direito, provêm deste contexto. O direito é ontologicamente construído como um instrumento de garantia e legitimação de um sistema político e econômico fomentador de injustiças e provedor de dominações.

No entanto, hoje os paradigmas do direito e os modelos constitucionais já estão em crise e não conseguem reproduzir e legitimar um sistema hegemônico de forma simplificada. A libertação desses paradigmas é uma saída que se busca à dominação histórica reproduzida pelo status quo estabelecido. Para alcançar esse fim cabe a proposição de uma "transontologia" do direito, semelhante à concepção que Dussel utiliza para a filosofia. Essa transontologia ${ }^{86}$ do direito deverá ter a capacidade de ouvir os clamores do povo, das lutas sociais, dos sentimentos mais profundos dos sujeitos sociais vitimados por um sistema então dominante. Irá além, de considerar os sujeitos de direitos estipulados pelas normas positivadas, atingindo o Outro, a exterioridade. O desafio será atender as demandas populares coletivas, efetivar os direitos fundamentais dos povos, lidar com os conflitos de massa a partir da ótica popular prezando por uma relação de compartilhamento não depreciativo dos bens naturais, entre outros.

Há uma necessidade de se repensar o paradigma e 0 constitucionalismo com base em um modelo de participação popular, ampliada e concebida desde os grupos excluídos, e não uma teoria comunicativa preconcebida com valores próprios e com uma formação eurocêntrica. 0 paradigma, ou modelo de um sistema político, não emergirá da vontade de juristas progressistas, que almejam mudanças. A ruptura paradigmática deverá ser realizada pelo povo, pela hiperpotentia, capaz de subverter a ordem injusta estabelecida com sua práxis. As lutas sociais concebidas por um bloco contrahegemônico deverão ir além da busca de saídas individuais, tais como observadas atualmente, mas cultivando a formação de um novo paradigma popular e latino-americano.

\footnotetext{
86 "La liberación es el movimiento mismo meta-físico o transontológico por el que se traspasa el horizonte del mundo. Es el acto que abre la brecha, que perfora el muro y se adentra en la exterioridad insospechada, futura, nueva en realidad." (DUSSEL, 2011, p. 108).
} 
Para isso, estas pautas populares devem ser sustentadas e o povo exercitar sua vanguarda. Logo, estes anseios de transformação devem potencializar-se "[...] na rebelião dos povos oprimidos e excluídos da periferia em suas lutas pela Segunda Emancipação, no novo postulado: Alteridade, Solidariedade, Libertação!" (DUSSEL, 2007, p. 164).

2.1.3. A importância da transformação paradigmática do sistema de direitos

Uma sociedade que convive com uma realidade sistêmica em que os cidadãos sem direitos prevalecem numericamente frente aos agraciados por direitos, apresenta uma chaga profunda, merecedora de tratamento. Ao vislumbrar uma perspectiva transontológica e transmoderna para conceber 0 novo direito, o sistema que fundamenta e irradia esse direito renovado, também deve ser transformado.

Dussel trata desse sistema de direito subsumido ao sistema político, em que irá se externar a garantia procedimental formal de legitimidade, a participação dos cidadãos e a busca por uma pretensão política de justiça nesse referido quadro político (2001, p. 150). No entanto, a pretensão política de justiça jamais será satisfeita com a manutenção de cidadãos excluídos do sistema de direitos. Esses cidadãos desprovidos de direito são vítimas em potencial da ordem econômica, cultural, social estabelecida no status quo. Ao lutarem por reconhecimento de direitos, esses cidadãos despertam o momento criador do que deve ser concebido como direitos humanos (DUSSEL, 2001, p. 151). Direitos esses que se debruçam no concreto e na conjuntura histórica, não em uma perspectiva metafísica ou relativista frágil. Isso demonstra, em evidência, que esses novos direitos são frutos de conquistas históricas 
advindas de lutas anteriores, responsáveis por incorporá-los ao sistema de direitos.

Diante dessa incorporação, já pode ser observada uma formação da "pretensão política de justiça" que parte do Outro, da vítima sistêmica, na conformação desse novo sistema, ou seja, indo além do que as convenções internacionais de direitos humanos ${ }^{87}$, ou os direitos fundamentais, previstos nas Constituições, algumas vezes oferecem. Justamente porque parte do real que está latente, do exercício concreto da política em sua esfera mais crua, a luta popular.

Esses são os momentos determinantes da sociedade, capazes de instaurar uma nova ordem, ocasiões revolucionárias. Enrique Dussel observa algumas particularidades para que essas transformações atinjam o sistema de direito, que considerará os direitos em sua esfera material, institucional formal e de factibilidade. Em um primeiro momento é fundamental estabelecer princípios críticos democráticos. Esses princípios devem partir de uma ética-crítica pautada na pretensão de bondade ${ }^{88}$, a qual definirá princípios práticos (2001, p. 161). Logo, aqueles princípios pautados em mero discurso abstrato, distante do materialismo histórico apresentado concretamente não são resultados desse novo sistema de direitos. Eles devem ser práticos e cumprir seus elementos éticos junto aos trabalhadores/as explorados pelo sistema ainda hegemônico. Assim, será considerado o Outro, excluído, que ao invés de ser incluído homogeneamente como igual a qualquer outro em um sistema dominante, reconstrói o sistema como sujeito ativo e diferenciado entre os oprimidos, capaz de alcançar consensos entre os povos, sem perder de vista o projeto popular. Dussel exemplifica a compreensão desse tipo de construção

\footnotetext{
87 "Antes de tudo constatemos o fato de que os assim chamados direitos humanos, os droits de l'homme, diferentemente dos droits du citoyen, nada mais são do que os direitos do membro da sociedade burguesa, isto é, do homem egoísta, do homem separado do homem e da comunidade". MARX, Karl. Sobre a questão judaica. Tradução de Nélio Schneider e Wanda Caldeira Brant. São Paulo: Boitempo, 2013, p. 47.

${ }^{88}$ A pretensão de bondade deve ser cumprida materialmente para a produção e a reprodução da vida humana em comunidade que equivale a: pretensão de validade (formal), a pretensão de verdade (material), a pretensão de eficácia (factibilidade) e a pretensão ético-crítica (parte das vitimas sistêmicas). Elemento formal, material e factibilidade são fundamentais, conforme destacado. (DUSSEL, 2001, p. 146-147)
} 
principiológica com a lição dada pelos zapatistas, que apontam a sociedade burguesa, no caso deles a mexicana, responsável por operarem um comando, pelo simples ato de mandar mandando. Diferentemente dos zapatistas, onde os que mandam, mandam obedecendo (2001, p. 165).

Um segundo momento fundamental é a transformação do sistema de direito em sentido estrito. Isso se configura, justamente quando os sujeitos excluídos, os sem direitos, deixam de ser objetos dominados e passam a sujeitos atuantes e transformadores. É a "subjetivação que os faz aparecer na história como atores de movimentos sociais transformadores (às vezes, revolucionários)" (DUSSEL, 2001, p. 166). Os novos direitos, mais do que meras previsões, devem estar amparados por mecanismos que os concretize. Assim, o trajeto inicial de uma autoconsciência da negatividade de direitos e uma consequente ação política atuante, poderá efetivar direitos desde uma inovação sistêmica.

Por fim, há uma necessidade de reconhecimento e instituição do novo sistema de direitos perante a sociedade. Esse período consistirá naquele momento histórico em que ações, antes vistas como afronta à ordem, ganham ares de legítimas, e com isso mesmo que por um tempo ilegais, tendem a modificação textual (DUSSEL, 2011, p.168). Não consiste em uma legitimidade alheia dos anseios de mudança, mas compartilhada e formadora de consensos desde a classe subalterna. Para além das leis, a mudança sistêmica decorrente das lutas populares tende a levar à ruptura constitucional.

Mesmo um sistema de direitos concebido e legitimado desde as classes populares, em uma dinâmica que atende a descolonialidade do poder e saberes, que rompa com a estrutura capitalista e respeite uma interculturalidade em sua confecção, também servirá para o exercício de coação legítima. Em certos períodos, o caminho de um projeto popular em direção à emancipação real dos povos sofrerá alguns reveses de grupos não interessados nessas mudanças, sobretudo, as elites despojadas do poder. Assim, a coação será legítima quando acordada mutuamente na comunidade, 
possibilitada por uma lógica racional de consenso para cumprimento do pacto. Não configurando caso de dominação externa (DUSSEL, 2009, p. 305).

Em uma de suas obras clássicas, Política de la liberación: arquitectónica, Enrique Dussel não titubeia em estabelecer algumas diretrizes e evidencia que: "sem legitimidade, o poder não tem forma; sem vontade de vida, o poder não tem conteúdo; e sem institucionalização, o poder se dissolve na impossibilidade de seu exercício" (tradução livre) (2009, p. 285).

\subsection{A concepção de Estado de Direito e a insuficiência das instituições para uma análise jurídico-transformadora da América Latina}

A concepção hegemônica do direito na atualidade, conforme destacada no debate paradigmático, é constituída a partir de um Estado de Direito próprio, amparado por teorias institucionais construídas ao longo da modernidade. $\mathrm{O}$ direito vigente apresenta-se assim, articulado em um horizonte político liberal, onde suas instituições foram forjadas e desenvolvidas, ousando universalizar valores que sustentam determinada estrutura jurídica (LEONEL JÚNIOR, 2013b). Logo, os processos constitucionais e as formações institucionais, em larga medida, são edificados a partir de uma construção paradigmática própria. Assim, com a crise de paradigmas colocada, desgastam-se os modelos institucionais e constitucionais hegemônicos, conforme tratado até agora.

Ao analisar essas instituições que sustentam o Estado de Direito, difundiram-se elementos e teorias que suportam concepções como a tripartição de poderes de Montesquieu (entre Executivo, Legislativo e Judiciário), o mecanismo de freios e contrapesos entre eles, o respeito à hierarquização normativa, a formalização dos direitos fundamentais, a representatividade democrática, o monismo estatal, entre outros. Talvez estes sejam as 
características mais contundentes de um Estado de Direito. Mesmo que modificado, devido os percalços históricos, reconstruído sobre características de Estado Social, e, posteriormente, de Estado Democrático de Direito, a estrutura liberal ainda permanece.

Independente da região específica, sobretudo ao tratar da América Latina, as instituições foram constituídas em uma tentativa de adaptar a realidade às construções e concepções jurídicas provenientes da Europa e dos Estados Unidos. O movimento inverso não ocorria, ou seja, a reflexão jurídica a partir da realidade vivenciada para a construção de um direito próprio e afim às características dos povos latino-americanos.

Atualmente, uma análise ontológica do direito a partir dos povos latinoamericanos, além de algumas experiências institucionais diferenciadas e construções de novas tópicas jurídicas nos fazem refletir sobre os rumos do Estado de Direito e da sua fundamentação liberal na América Latina.

Algumas Constituições, como a venezuelana, boliviana e equatoriana, juntamente com o próprio modus operandi da política nesses países, questionam até certo ponto, as teorias clássicas eurocêntricas e os caminhos tortuosos que o direito percorre. Apesar de apresentarem um quadro constitucional e institucional, em parte, inovadoras, ainda caminham lentamente para construção de um novo paradigma político para o direito.

Cabe avaliar as insuficiências das instituições desenvolvidas e da manutenção do Estado de Direito para inferir a atual dinâmica e possibilidades de desenvolver teorias próprias, amplamente garantidoras de direitos, e conformadas ao contexto jurídico e político da América Latina.

2.2.1. O contexto institucional e o direito moderno: a crítica ontológica desde o Outro. 
As instituições desenvolveram-se na modernidade com a clara lógica de garantir as independências individuais frente ao contexto social e político vivenciado (LEONEL JÚNIOR, 2013c). As ideias de respeito aos contratos, da manutenção do núcleo familiar e da propriedade, fortalecidas com a Revolução Francesa, compõem a tríade basilar do direito moderno. As liberdades civis são prevalentes nesse cenário frente a qualquer outra.

Benjamin Constant sintetiza a diferenciação do que era entendido como liberdade na antiguidade com o que vige na modernidade, ressaltando a importância, segundo ele, desta evolução histórica.

O objetivo dos antigos era a partilha do poder social entre todos os cidadãos de uma mesma pátria. Era isso o que eles denominavam liberdade. O objetivo dos modernos é a segurança dos privilégios privados; e eles chamam liberdade as garantias concedidas pelas instituições a esses privilégios (CONSTANT, 1985, p. 15-16).

O pensador liberal expõe a função das instituições desde uma perspectiva hegemônica do liberalismo nos países centrais. A característica ressaltada no indivíduo, não seria de sua perspectiva cooperadora, mas sua capacidade de influenciar. Diante destes elementos, o direito recebe uma roupagem própria, justificando a criação do Estado de Direito. Este seria necessário para assegurar a liberdade política aos liberais, mesmo que esses se dediquem, prioritariamente, ao exercício de suas liberdades civis e interesses próprios.

A partir deste cenário, observa-se uma ontologia do direito, difusora de teorias institucionais advindas com a modernidade. Assim, o direito moderno atua como mediador das relações sociais, dando um ar de normalidade ao sistema político vigente, o qual deverá remeter-se às normas nos momentos desta mediação. 
Certamente, uma crítica ontológica do direito deve emergir para desmistificar esta construção social.

Aquilo que se apresenta cotidianamente não é 'evidente' por corresponder a alguma verdade objetiva, mas por adequar-se às formas de ser oriundas das relações sociais que mediam a formação de determinado tipo de sociabilidade (SARTORI, 2010, p. 14).

A forma jurídica, do mesmo jeito que a mercadoria no sistema capitalista, é passível de fetichização, previu o jurista soviético Pasukanis. Como se sua inerência estivesse na rigidez normativa possibilitadora da calculabilidade e da segurança jurídica. Observa-se que a forma histórica do direito é materialmente determinada ${ }^{89}$. Assim, a forma jurídica é inseparável da forma mercadoria, evidenciando o elo em relação ao capital, além de não constituir mera reprodução das formas aparentes dadas ao direito, como as normas, as decisões judiciais, as retóricas argumentativas, que não passam de consequências dessa forma jurídica essencial, atreladas ao modo de produção.

Ademais, o direito moderno é concebido como algo já constituído, parte da totalidade do ser social e suas mediações coisificadas, aptas a reproduzirem o sistema. Negando assim, a exterioridade, o Outro.

O Outro, que não é diferente (como afirma a totalidade) mas distinto (sempre outro), que tem sua história, sua cultura, sua exterioridade, não foi respeitado; não se lhe permitiu ser outro. Foi incorporado ao estranho, à totalidade alheia (DUSSEL, 1986, p. 58).

\footnotetext{
${ }^{89}$ Marx “(...) descobre, assim, o profundo vínculo interno existente entre a forma jurídica e a forma mercantil. Uma sociedade que é constrangida, pelo estado de suas forças produtivas, a manter uma relação de equivalência entre o dispêndio de trabalho e a remuneração, sob uma forma que lembra, mesmo de longe, a troca de valores-mercadorias, será constrangida igualmente a manter a forma jurídica. Somente partindo deste momento fundamental é que se pode compreender por que toda uma série de outras relações sociais reveste a forma jurídica". (PASUKANIS, 1989, p. 28).
} 
Há uma necessidade em pensar o direito, de acordo com Dussel, partindo da exterioridade excluída da construção do direito moderno, dando lugar a uma novidade ôntica e jurídica. Um Outro, que configuraria o sujeito que está na periferia do sistema mundo, seguindo a visão dominante, e que deveria assumir o protagonismo de sua história, da construção de suas instituições e do seu direito, conforme foi salientado.

Logo, este mito sacrificial de um racionalismo universalista deve ser superado, defendendo Dussel uma mundialidade transmoderna ${ }^{90}$, já citada. Faz-se necessário aproveitar o caráter emancipatório advindo com a racionalidade moderna e articulá-lo à alteridade do Outro, latino-americano negado em sua construção racional de instituições próprias.

Mesmo ao trazer uma análise jurídica mais avançada, por meio das leituras pós-positivistas, como em Dworkin, observa-se uma insuficiência no avanço de uma racionalidade jurídica desde o Outro. Em determinado momento ele apostará na racionalidade do sistema a partir do próprio juiz, do Judiciário ou outras premissas normativas e decisões judiciais. Mesmo a defesa constitucional que o pensador faz da "leitura moral", não representa toda a prática constitucional, nem supre as limitações apontadas, além de não abandonar a perspectiva liberal.

O direito tão só como uma prática social interpretativa ainda é insuficiente para as respostas transformadoras almejadas. Dworkin chega a propor a analogia entre a dinâmica interpretativa e o que concebe como romance em cadeia ${ }^{91}$. Assim, ele analisa a prática jurídica como um dado e busca uma interpretação a partir disto, sem o cuidado de apreender a totalidade e exterioridade das relações sociais. Portanto, o problema não é

\footnotetext{
90 "Contra o racionalismo universalista, não negaremos seu núcleo racional e sim seu momento irracional do mito sacrifical. Não negaremos então a razão, mas a irracionalidade da violência do mito moderno; não negamos a razão, mas a irracionalidade pós-moderna; afirmamos a "razão do Outro" rumo a uma mundialidade transmoderna." (DUSSEL, 1993, p. 24).

91 "Um grupo de romancistas escreve um romance em série; cada romancista da cadeia interpreta os capítulos que recebeu para escrever um novo capítulo, que é então acrescentado ao que recebe o romancista seguinte, e assim por diante." (DWORKIN, 2003, p. 276).
} 
meramente interpretativo, mas ontológico. A aparência não basta, é importante atingir a essência do direito.

Insiste-se em determinada ordem institucional, mantenedora de uma potestas fetichizada, como "moldura comum de interpretação compartilhada entre pessoas de um mesmo contexto social" (MACCORMICK, 2008, p. 8). Uma interpretação eivada de valores e interesses individuais ou de grupos específicos, como explicita MacCormick em trechos de sua obra Retórica e o Estado de Direito $^{92}$. Logo, ao tratar de uma sociedade, não é possível homogeneizar o contexto para aplicar o direito. Trata-se de sociedade heterogênea e dividida em classes, hegemonizada por instituições concebidas sob a égide liberal. Logo, os topoi ${ }^{93}$ e os princípios aceitáveis também são geridos em cenários de prevalência de um projeto político liberal no Estado de direito, inviabilizando a emersão do Outro, mantido na exterioridade do sistema econômico e jurídico. Esses topoi dominantes constituídos, em determinado momento histórico e lugar, formam a força hegemônica que alcança todas as áreas do conhecimento, não se atendo ao direito (SOUSA SANTOS, 2002, p. 101-102).

Desde a década de 50, Orlando Gomes faz críticas contundentes ao direito e suas instituições. Condena as perspectivas pretensamente universais e insuficientes para a compreensão e funcionamento de uma sociedade complexa e diversa.

A monótona imagem de uma história universal em linha reta não satisfaz aos espíritos mais geométricos. Assim, para os que compreendem o processo histórico como o fluxo contínuo de fases sucessivas perfeitamente distintas e precisamente configuradas, tais desajustamentos entre as peças da máquina social só desapontam quando a folga é demasiado grande, tal

\footnotetext{
92 "Tal interpretação envolve interesses e valores de grande importância para os indivíduos e grupos. Por isso, especialmente no contexto de um julgamento, ela é acompanhada por uma prática argumentativa, e por um processo de tomada de decisão entre argumentos rivais envolvendo questões de interpretação e de tomada prática de decisão". (MACCORMICK, 2008, p. 8).

${ }^{93}$ Aristóteles denominava de topoi os lugares comuns, verdades aceitas que direcionam nosso argumento. Cf. (ARISTÓTELES, 2005).
} 
como ocorre nestes dias tumultuosos. O Direito está tão envelhecido que parece exclusivamente feito de resíduos (1955, p. 18).

Buscam-se contínuas saídas e inovações jurídicas, ainda sem a inclusão do Outro, e sem o questionamento da estruturação do que se entende por Estado de Direito. A crítica ontológica é necessária ao buscar a reformulação do que é entendido por direito e por seu paradigma vigente corroborador do constitucionalismo moderno.

Joaquin Herrera Flores propõe uma ontologia do direito com carga materialista forte, não se atendo só aos valores em si para sua concepção, "[...] mas, de acordo com modos de existência que tendam a criar e generalizar novos marcos de composição e interação "rizomáticos" (2009, p. 186). Além disso, o fato de pensar novas instituições e um novo direito, requer aceitar a modernidade, não como modelo único eurocêntrico, mas "há muitas formações sociais que também situam em algum ponto de sua história um renascimento cultural que inaugura uma modernidade [...] sempre inaugurando algo novo" (FLORES, 2009, p. 22). A ontologia do direito deverá partir deste Outro, da hiperpotentia latino-americana situada na base da sociedade de classes, vitimada pela conformação liberal do Estado e do direito, e com isso forjar as instituições vindouras, desde essa transontologia, fazendo jus a um projeto transmoderno.

2.2.2 A dinâmica de desenvolvimento do Estado de Direito e a crítica à manutenção da estrutura liberal para a garantia de direitos

O debate em torno do pluralismo jurídico é de suma importância na temática ora discutida, pois trata de desmistificar a propalada completude 
jurídica diante de situações que o sistema jurídico não consegue apresentar respostas adequadas, nem reconhecer grupos responsáveis por formulações jurídicas próprias.

A ideia de Estado de Direito remete à perspectiva de um poder político constituído e também limitado por amarras jurídicas previamente estabelecidas, entre elas e a Constituição. Assegurando, assim, garantias aos indivíduos frente o poder do Estado.

O liberal italiano Norberto Bobbio faz a distinção entre o Estado de direito e a doutrina Liberal do Estado.

O Estado liberal se afirma na luta contra o Estado absoluto em defesa do Estado de direito e contra o Estado máximo em defesa do Estado mínimo, ainda que nem sempre os dois movimentos de emancipação coincidam histórica e praticamente (1997, p. 18).

Inclusive, em um Estado Social de Direito ou Democrático de Direito, as características ínsitas à lógica liberal são mantidas, mesmo que de forma atenuada, conforme já disposto. Não é por acaso que as relações jurídicas estabelecem-se majoritariamente em uma dinâmica individualista, e na qual os direitos fundamentais, entre eles a liberdade, se mantêm na seara do formalismo, não garantindo direitos materiais à maioria dos povos.

A moldura liberal do pensamento jurídico dominante admite apenas os aspectos políticos da questão e repele seus termos sociais, apresentando a liberdade sob uma forma puramente abstrata, vazia de conteúdo social, aristocratizada num sistema de franquias, que interessa a uma minoria privilegiada (GOMES, 1955, p. 6-7).

Diante de uma análise deste paradigma político do direito, compreende-se a própria lógica de construção jurídica inserida em um percurso histórico, em que determinados grupos sociais prevaleceram sobre outros e 
utilizaram-se do direito como instrumento de poder. Assim, a concepção liberal tenderá atrelar sempre a construção jurídica. Esta apreciação só tem sentido ao considerar, principalmente, as novas etapas do desenvolvimento capitalista, preponderante para o delineamento da Ciência Jurídica.

Após o início do desenvolvimento capitalista, sobretudo, depois da Revolução Industrial, vigorou a concepção clássica de liberalismo. Dessa forma, o Estado Liberal se fez presente com maior força na Europa, devido ao grande desenvolvimento econômico. Após o advento das lutas socialistas, ocorre um enfraquecimento do Estado Liberal e propõe-se um Estado Social, período em que emergem os direitos de $2^{\mathrm{a}}$ geração, pautados na igualdade.

Os grandes responsáveis, de acordo com Paulo Bonavides, pela base ideológica do Estado Social foram Rousseau e Marx. O primeiro com a teoria pura da democracia moderna e o segundo dando uma base científica ao socialismo, numa qualificada refutação às teorias capitalistas (1996).

Contudo, "o Estado Social se compadece com regimes políticos antagônicos, como sejam a democracia, o fascismo e o nacional-socialismo." (BONAVIDES, 1996, p. 205-206). Dessa forma, vislumbrou-se a necessidade de criação do Estado Social de Direito, o qual estaria pautado em elementos democráticos e constitucionais. Neste tipo de Estado busca-se superar a contradição entre igualdade política e desigualdade social. No entanto, os percalços do Estado Social de Direito são evidentes, a partir do momento que ele busca compatibilizar o capitalismo ao bem estar social. Na prática, de acordo com Paulo Bonavides;

Ainda que institucionalizado no chamado Estado Social de Direito, permanece sempre sob este - representada por seus grupos políticos e econômicos mais reacionários e violentos essa tendência e propensão do capitalismo ao controle econômico monopolista e à utilização de métodos políticos de caráter totalitário e ditatorial, visando a evitar, sobretudo, qualquer eventualidade realmente socialista (1996, p. 122123). 
Assim, na prática, prevalece o próprio espectro liberal no paradigma político do direito. Após o início da década de 90, com o Consenso de Washington, utilizou-se uma nova roupagem, denominada neoliberal, e, depois de 2008, em um momento recente de crise, buscam reerguer os pilares do capitalismo com medidas intervencionistas praticadas pelo Estado.

Neste panorama é inviável a garantia de direitos para todo o povo. Prova disso é o relatório da $\mathrm{FAO},{ }^{94}$ o qual aponta que um total de 1.020 bilhões de pessoas passaram fome em $2009^{95}$, o que representa um número recorde. $\mathrm{Na}$ Ásia e no Pacífico calcula-se que cerca de 642 milhões de pessoas sofrem com fome crônica, 265 milhões na África Subsaariana, 53 milhões na América Latina e no Caribe, 42 milhões na África do norte e Oriente Médio e 15 milhões nos países desenvolvidos (FAO, 2009).

Toda esta crise demonstra a insuficiência de um Estado de Direito, o qual tende a contribuir para um colapso social. Atualmente, na visão de alguns juristas com uma visão pós-positivistas, ainda é aceito, inclusive, propostas restritivas de eficácia contida de direitos fundamentais (SILVA, 2004), algo crítico em um cenário apresentado de perspectivas crescentes de fome e miséria. A partir do momento que as normas fundamentais são classificadas como programáticas, abre-se o precedente para a restrição das demais normas e não realização de seus preceitos.

Conforme destacado, no aspecto econômico desta estrutura jurídica liberal, o que prevalece é a liberdade da empresa, a desregulamentação do setor produtivo, o valor da propriedade privada, a livre circulação de mercadorias, a "força" do mercado, etc. Para resguardar a segurança, a calculabilidade e a previsibilidade destas benesses econômicas devidamente concentradas, utiliza-se o direito, inclusive em sua forma coercitiva, ao usarem

\footnotetext{
${ }^{94}$ Food and Agriculture Organization - Organização das Nações Unidas para Agricultura e Alimentação.

95 "Mais pessoas morreram de fome no nosso século que em qualquer dos séculos precedentes. A distância entre países ricos e países pobres e entre ricos e pobres no mesmo país não tem cessado de aumentar. (...) No que respeita à promessa de liberdade, as violações dos direitos humanos em países vivendo formalmente em paz e democracia assumem proporções avassaladoras." (SOUSA SANTOS, 2002, p. 24)
} 
a força do Estado quando a elite governante julga necessário. No liberalismo, a igualdade é concebida como igualdade perante a lei, e a liberdade, como a possibilidade de todos em desenvolver e expressar sua existência individual. Não por acaso, que manifestações trabalhistas, grevistas, camponesas são criminalizadas ao invés de serem tratadas como políticas sociais. Ou seja, cerceiam a inovação trazida na perspectiva de constituírem a hiperpotentia.

Essa análise da formação do Estado deve também ser realizada de uma forma mais apartada do direito, para evidenciar a autonomia relativa de um frente ao outro. Ou seja, quebrar o monismo estatal liberal e repensar o direito a partir das classes populares, que não estão à frente do aparelho estatal, como lembra Boaventura de Sousa Santos.

\begin{abstract}
Neste momento da análise, sublinho apenas que, para despensar o direito num período de transição paradigmática, deve forçosamente começar-se por separar o Estado do direito. Essa separação tem dois propósitos, o primeiro dos quais é mostrar que não só o Estado nunca deteve o monopólio do direito como também nunca se deixou monopolizar por ele. Muito para além da doutrina da raison d'état, o Estado constitucional funcionou geralmente tanto por meios legais como por meios ilegais. Essa conjugação de legalidade com ilegalidade (segundo a definição de ordem jurídica do próprio Estado) variou conforme as áreas de intervenção do Estado. Variou, sobretudo, de acordo com a posição do Estado no sistema mundial. Em segundo lugar, a rejeição arbitrária da pluralidade de ordens jurídicas eliminou ou reduziu drasticamente o potencial emancipatório do direito moderno (2002, p. 172).
\end{abstract}

Outro aspecto da estrutura jurídica liberal, que permeia 0 constitucionalismo moderno, é o quadro apresentado pela democracia representativa, onde "mudam-se as peças, mas mantem-se o tabuleiro." Os representantes políticos são modificados a cada eleição, porém, mesmo com a renovação dos sujeitos, a transformação advinda das ações do Estado em prol da sociedade não ocorrem, ou acontecem simplesmente para manter a lógica, tida como democrática, estabelecida. 
A distância existente entre potentia e potestas, ou representado e representante, é uma das características responsáveis pelas distorções sistêmicas ${ }^{96}$. A representação é fundamental, mas não deve ser a única forma de concepção da política no pleito democrático.

Ademais, é importante salientar que o modelo eleitoral representativo, pautado pelas atuais instituições prevalecentes, contribui para assegurar a atual concepção limitada do Estado de Direito. Certamente, ao propor um modelo que utiliza um método de votação individualizado frente a outro modelo, por exemplo, que venha a prezar por Assembleias coletivas com exposição de razões, poderia demonstrar que métodos diferenciados têm o potencial de gerar resultados diferenciados. Sobretudo, quando esse modelo, utilizado na América Latina, é uma reprodução do modelo dos Estados Unidos, detentor de um Congresso com Senado e Câmara e uma separação de poderes desequilibrada. As estruturas liberais de Estado são implantadas em um ambiente politico-hegemônico preponderantemente conservador.

Para a mudança dessa estrutura de Estado, os países da América Latina reproduzem o modelo constitucional, lembrando que tal modelo foi forjado em contexto histórico e temporal distinto, além de ser direcionado para outra comunidade. A Constituição "definirá a forma arquitetônica do Estado, como sociedade política e civil" (DUSSEL, 2009, p. 293).

Nessa divisão de poderes incorporada pelas Constituições latinoamericanas, o poder legislativo será o responsável institucional por fomentar aquilo que Dussel tratou de sistema de direitos. Contudo, um instituto importado, em ambiente político conservador na América Latina, gerou o desequilíbrio dos poderes, tendo um Executivo mais forte, sobretudo no século XIX.

\footnotetext{
${ }^{96}$ Historicamente todos os clãs, etnias, tribos sempre tiveram um corpo de anciãos sábios, que exerciam o poder na comunidade. Esse corpo de anciãos ou SENADO (de sênior: o adulto mais velho) onde se decidiam e construíam a unidade da comunidade. Ex: Forma de demonstração dessa unidade era compartilhar o cachimbo passado pelos membros da Assembleia demonstrando unidade. Daí a expressão "cachimbo da paz" (DUSSEL, 2009, p. 286).
} 
O Poder judiciário também apresenta uma gênese que não soluciona as questões que se propõe a resolver. Ao partir de uma concepção solipsista de julgado, contribuindo para uma baixa legitimidade democrática dos juízes, já há uma limitação de apreensão da lide, que chegará ao fim, sem a busca de um consenso racional coletivo. Ademais, o "sistema judiciário não está habituado a falar com outras instituições. Esta é outra faceta do seu isolamento" (SOUSA SANTOS, 2011, p. 124).

Dussel elenca alguns fatores que seriam imprescindíveis para julgamentos mais justos, mesmo que os julgadores sejam seres humanos passíveis de falha. Ele destaca que o juiz deve reforçar características como o cultivo à boa memória, pois quanto mais conhecer casos anteriores singulares, por não se tratar de universais, e compreender a história e antecedentes, mais chance de acertar na decisão. A percepção intuitiva também servirá para avaliar a realidade e as estruturas e dinâmicas de poder envolvidas na lide. A capacidade de aprendizagem é outra qualidade fundante, pois servirá para conhecer outra realidade e erros já cometidos em situações similares. Essa capacidade ajudará também no cultivo da imaginação criativa para soluções inesperadas e diferentes das situações concretas. Ademais, decidir com prudência com relação aos afetados e ao próprio juiz é importante, além de ser essencial que tenha a virtude para decidir (2009, p. 308-309). Todos esses elementos, ligados também a certa aptidão para o exercício da função, devem estar atrelados a formas de julgamento mais factíveis e adequadas à realidade dos povos, não reproduzindo julgamentos a partir de bases sociais discriminatórias ou opressoras em suas variadas matizes.

Quase nenhum desses fatores é considerado para a seleção dos magistrados/as dentro da estrutura liberal que está sedimentada boa parte das Constituições da América Latina e, consequentemente, do Poder Judiciário. Já os mecanismos de aproximação do povo e das comunidades à Justiça, ainda são limitados e nem sempre resolvem as injustiças apresentadas de uma forma devida e, de fato, justa, se considerado concretamente a condição social das partes envolvidas. 
Os Tribunais e os juízes tendem a obstaculizar a efetividade dos direitos sociais, colocados como de segunda categoria, mesmo quando previstos, em decorrência de uma estrutura do sistema de justiça, que inviabiliza esse tipo de ação. Mesmo as cláusulas relacionadas à participação popular, como as de referendo e plebiscito, presentes nas Constituições dos anos 80 e 90 do século XX, dificilmente são implementadas por dependerem de aval dos poderes Executivo ou Legislativo. Talvez a criação de instituições que possibilitem a participação direta das pessoas e dos coletivos (nos bairros, comunidades) seja um indicativo futuro de melhora, pois possibilitaria um poder político e comunitário. Ali, o Poder Judiciário serviria como última instância fundante de uma vida civilizada. Algo que se aproxima de experiências de justiça indígena originária campesina, como ocorre em alguns lugares na Bolívia. De toda forma, avançar para além da estrutura liberal na conformação do poder judiciário, não é algo simples.

A divisão tripartida de poderes é concebida para ajudar a viabilizar o projeto liberal de poder através da dimensão institucional. Os liberais viam a representação política como uma necessidade. Não poderiam abrir mão do poder político, justamente para garantirem as liberdades individuais e seus interesses.

O sistema representativo é uma procuração dada a um certo número de homens pela massa do povo que deseja ter seus interesses defendidos e não tem, no entanto, tempo para defendê-los sozinho (CONSTANT, 1985, p. 23).

Ou seja, o tempo para os liberais deve ser priorizado para a garantia dos interesses particulares e o poder político deverá preservar isso.

Benjamim Constant ainda advertia aos liberais que ignoravam a relevância das instituições, focando somente os negócios, sob o risco de não sustentarem seus privilégios. 
O perigo da liberdade moderna está em que, absorvidos pelo gozo da independência privada e na busca de interesses particulares, renunciemos demasiado facilmente a nosso direito de participar do poder político (1985, p. 23).

A liberdade política, evidenciada hoje no ato do direito ao voto e ser votado, é um dos elementos do que conhecemos por democracia. Este sufrágio universal, tão custoso em épocas de ditaduras militares, atua hodiernamente, de forma preponderante, como legitimador de um processo estanque em sua estrutura, mesmo diante de Constituições avançadas no aspecto social. Stephen Holmes trata dos pré-compromissos constitucionais, e os paradoxos existentes diante da democracia, salientando a dificuldade de conjugar estes elementos. Em trecho de sua obra, traduzida para o espanhol, ele anuncia que "Este é um exemplo notável do paradoxo da democracia: os cidadãos podem aumentar seu poder atando suas próprias mãos." (Tradução Livre) (HOLMES, 1999, p. 253). Cabe retomar que a palavra paradoxo, diferente de contraditório, admite a convivência dos institutos. Assim, os próprios précompromissos constitucionais resguardam, muitas vezes, uma situação de injustiça e manutenção de instituições já desgastadas.

Além disso, a politica é reconhecida e considerada apenas em sua esfera institucional, na lógica do parlamento e das votações, conforme destaca Luis Tapia.

Uno de los rasgos del constitucionalismo moderno, en particular del liberal, consiste en el diseño del monopolio de la política a través de su concentración en el sistema de partidos y la prohibición de hacer política fuera de las instituciones organizadas y reconocidas por el estado. (2009a, p. 51).

A questão não é tão só modificar ou não modificar as normas sociais de uma geração para outra, mas questionar quem fará isso e para que. Enrique Dussel propõe a emergência de um Poder Cidadão. Este Poder instituído seria "a última instância fiscalizadora (que devesse ser a culminação de todo um 
procedimento permanente de participação dos membros da comunidade desde sua base) de todos outros Poderes e instituições" (DUSSEL, 2007, p. 70). Talvez, esta ação potencializaria a legitimidade de pré-compromissos menos destoantes das demandas populares.

$\mathrm{Na}$ Constituição da República Bolivariana da Venezuela surge importante elemento novo, que poderá semear formas próprias de estabelecer pré-compromissos institucionais. $O$ artigo $136^{97}$ chega a estipular como parte do poder público nacional, o Poder Cidadão. A própria Constituição ainda estabelece as formas viabilizadoras do protagonismo popular com poder vinculante, o qual poderá mudar até a própria Constituição ${ }^{98}$. Mesmo que a simples mudança constitucional, ainda não seja suficiente para uma mudança social.

O referendo, a consulta popular, a revogação do mandato, o poder cidadão e o eleitoral [...], a maneira de escolher o juízes do Tribunal Supremo de Justiça do Poder do cidadão e organizações da sociedade civil, que um simples cidadão possa iniciar o processo para ditar uma lei, tudo isso nos indica um espírito político novo: o da participação cidadã em uma democracia em que é o povo que tem a soberania e pode exercê-la permanentemente, não só nessas erupções vulcânicas que são as eleições sexenais. A democracia representativa (que tende a ser um movimento de cima para baixo) deve ser articulada com a democracia participativa (como movimento fiscalizador de baixo para cima) (DUSSEL, 2007, p. 153).

O Direito como qualquer coisa na atual sociedade tende a migrar do campo político para o mercado. Os juristas, por vezes, deixam de lutar por Justiça e tornam-se colaboracionistas do sistema, não buscando modificar o

\footnotetext{
97 Artículo 136. El Poder Público se distribuye entre el Poder Municipal, el Poder Estadal y el Poder Nacional. El Poder Público Nacional se divide en Legislativo, Ejecutivo, Judicial, Ciudadano y Electoral.

98 Artículo 70. Son medios de participación y protagonismo del pueblo en ejercicio de su soberanía, en lo político: la elección de cargos públicos, el referendo, la consulta popular, la revocatoria del mandato, la iniciativa legislativa, constitucional y constituyente, el cabildo abierto y la asamblea de ciudadanos y ciudadanas cuyas decisiones serán de carácter vinculante, entre otros.(...).
} 
que está estabelecido. Assim, os direitos passam a possuir mero efeito encantatório, prevalecendo tão só uma retórica esvaziada. Os meios são diversos na busca de uma construção jurídica diferenciada, caberá, a partir de concepções políticas e projetos de sociedade, optar por alguns, mesmo que custe a própria existência do que se concebe atualmente como Estado de Direito.

Assim, está posto um enorme desafio para os juristas latinoamericanos. Pensar um modelo constitucional e, para além disso, repensar um direito, não para o seu povo, mas com e a partir dele; revisitando toda uma história de submissão e importação de modelos exóticos à dinâmica cultural própria. Certamente, não é o caso de conceber instituições desde o que eram os povos originários destes continentes, mas a partir da lógica peculiar de reprodução social e com caráter emancipatório, em uma perspectiva de contraposição aos métodos e modelos dominadores e neocoloniais.

Mesmo que seja possível conceber construções jurídicas garantidoras, a partir das instituições vigentes, observa-se uma insuficiência na garantia de direitos e um desgaste funcional. Em épocas anteriores, Orlando Gomes antevia esta inércia jurídica quanto às possibilidades de reflexão institucional.

A teimosa persistência no atual ciclo histórico de valores jurídicos que não sucumbiram com o nascimento da nova estrutura social possibilita a existência de instituições caducas, que só conseguem adaptar-se às novas condições mediante processos artificiais, quase todos de compulsão (1955, p. 19).

O liberalismo permeador das concepções institucionais, sobretudo na América Latina, demonstra uma patente dificuldade em realizar as promessas da Modernidade ocidental capitalista. Logo, mesmo o que se concebe como Estado de Direito não poderá se sustentar. Provável que será o momento de romper com as certezas jurídicas, seguranças de expectativas, e garantias meramente individualizadas. Apesar da dificuldade desta ocorrência partir dos próprios juristas. 
[...] uma revisão ruptural dos paradigmas tradicionais (positivistas), que pudesse significar verdadeira "revolução científica" no sentido em que a entendeu Thomas Khun, é algo pouco provável, até porque os juristas não têm a tradição nem o ímpeto de afrontar os paradigmas da ordem vigente, mesmo que essa ordem seja injusta e, portanto, ilegítima (MACHADO, 2011, p. 29).

Por isso, mais uma vez afirma-se que a crítica ontológica se faz necessária partindo da exterioridade, ou seja, do povo trabalhador vitimado e excluído capaz de forjar um novo projeto de sociedade e consequentemente de direito, exercendo a hiperpotentia e reconstruindo a história da América Latina.

2.2.3. Da dialética à analética social do direto: contribuições de Lyra Filho e Enrique Dussel.

O método marxista permeia a análise realizada até agora e não seria diferente da análise jurídica propriamente dita. Não há nada mais complicado, ao apresentar a alguém o Direito, do que dissolver as falsas e enviesadas imagens que se tem do mesmo. Estereótipo, aceito pelo senso comum, como se de fato fosse o direito.

Ora busca-se liga-lo à natureza das coisas, ao universo, a algo metafisicamente considerado, ora na lei como se estivesse inevitavelmente atrelado ao Estado e condicionado a reproduzir somente as normas estatais. Como bem lembra Roberto Lyra Filho;

Uma ciência verdadeira, entretanto, não pode fundar-se em "dogmas", que divinizam as normas do Estado, transformam essas práticas pseudocientíficas em tarefa de boys do 
imperialismo e da dominação e degradam a procura do saber numa ladainha de capangas inconscientes ou espertos. (2006, p.10-11).

A perspectiva de dogmatização representa um fenômeno cristalizador do direito, o qual trava os avanços progressistas na área. A ação de seus defensores tende a considerá-lo como verdade absoluta, a qual passa por cima de qualquer coisa e não é passível de qualquer contestação ou alternativa ao dogma hegemônico. Dessa forma, mascara a ideologia que o sustenta (LYRA FILHO, 1980). O reducionismo defendido pelos partidários dos dogmas nega 0 método dialético ao qual o direito está submetido no processo histórico real. Mesmo aqueles defensores das teorias pós-positivistas no campo jurídico, que tratam de substituir os positivistas, na atualidade, em análises mais arrojadas, contribuem para a colonialidade do saber jurídico, isto porque ainda referendam as interpretações e as teorias que se filiam as perspectivas de reprodução da restrição do fenômeno jurídico às normas estatais. Desse modo, "inviabiliza-se o reconhecimento da juridicidade de determinadas normas sociais não-estatais, o que não deixa de ser uma fonte de poder: no caso, tratase do poder social de "conferir" juridicidade a determinadas relações sociais" (DIEHL; LEONEL JÚNIOR, 2012, p. 795).

O direito não está pronto e acabado pelo fato de existirem normas que tratam de inúmeras questões na sociedade. Lyra Filho aponta de forma pertinente que ele segue em movimento, o direito "é sendo" (2006, p. 11). Assim, a essência do direito pode ser alcançada a partir de uma ontologia dialética, trilhando rumo à transontologia já tratada, onde se ampliará o foco do direito extravasando o produto oferecido como tal pelo positivismo. Da mesma forma, demonstra que nenhuma ordem pode manter-se indefinidamente intacta, apesar de parcela dessa ordem permanecer, mesmo com alguma mudança, algo que é inerente à dinâmica desordenadora (LYRA FILHO, 1986) e compõe a dialética social.

Trata-se de considerar o direito e suas teorias como ferramenta viva e em constante processo de reflexão e transformação. Assim, essa força 
despertada nos momentos efervescentes da hiperpotentia, capaz de desordenar o sistema estabelecido traz ao cenário novos sujeitos, até então, invisibilizados socialmente capazes de reordenarem, a partir de novos pilares, a sociedade. O direito ao invés de, tão só, resistir a esse processo de mudança, uma vez que se constitui em teoria dinâmica a serviço dos povos excluídos e dos trabalhadores/as, pode ser instrumento de estimulo à ruptura. Ele é parido nesse processo histórico, a partir de uma práxis, que ousa contribuir para a emancipação de povos dominados historicamente por amarras econômicas, políticas, sociais e culturais. Essa concepção rompe com o senso comum de percepção do direito como mero produto normativo estabelecido por legisladores "iluminados" em prol de uma "vontade geral", reduzindo o direito à lógica estatal.

Daí a importância em considerar um pluralismo jurídico sem "desvios", ou seja, incapaz de analisar a historicidade da esfera jurídica e tratando o direito como mera regulação social. Assim, esse "desvio" pluralista poderia evidenciar-se na universalização do fenômeno jurídico ao desconsiderar as especificidades históricas, diretamente ligadas ao modo de produção que permitiu ao direito desenvolver-se de tal forma. A crítica ao monismo jurídico deve ser realizada sem omitir a função que desempenha a forma jurídica, que não é meramente normativa.

Para Lyra Filho, o pluralismo jurídico progressista cumpre um papel político fundamental, uma vez que aponta um projeto.

E a questão é, em última análise, de fundo político, uma vez que o pluralismo jurídico progressista, enquanto característica essencial da abordagem dialética do Direito, representa uma nítida opção pelo socialismo democrático (1982, p. 31-32).

Isso é sinal que, para Roberto Lyra Filho, o direito tem condições de incidir em um direcionamento distinto que o estabelecido pelo modo de produção vigente. Ademais, esse pluralismo progressista será puxado pela luta 
de classes e grupos, a partir da dialética social do direito ${ }^{99}$. Sobre a dupla base "interpenetrante das infra-estruturas internacional e nacional é que se armam os aspectos derivados e superestruturais - de um lado, estabelecendo a coesão (força centrípeta), e, de outro, a dispersão (força centrífuga)." (2006, p. 44). Essa é uma forma de se buscar a essência do direito sem cair em ranços ideológicos ou perspectivas metafísicas vazias. O direito "se apresenta como positivação da liberdade conscientizada e conquistada nas lutas sociais e formula os princípios supremos da Justiça Social que nelas se desvenda" (2006, p. 44).

Classes espoliadas, grupos oprimidos organizam-se e dão alcance jurídico-prático às reivindicações necessárias, com liberdade política e civil de consciência e subsistência, justa repartição dos frutos do trabalho, participação no governo e demais elementos garantidores do que é essencial à vida e à dignidade humana. (LYRA FILHO, 1982, p. 34)

Toda essa análise dialética feita por Lyra Filho tem clara influência marxiana na sua aplicação. Sobretudo, a partir da interlocução entre Marx e Hegel, para combater a perspectiva idealista do último, negando-a, e a própria negação da negação, emergindo entre esses o movimento dialético (LYRA FILHO, 1983). O método em Marx leva as análises teóricas ao concreto para o exame da realidade: "o concreto é concreto porque é a síntese de múltiplas determinações, portanto, unidade da diversidade" (MARX, 2011a, p. 54). Concretude essa que não é abstrata, por estar inserida na totalidade e atrelada à dinâmica do modo de produção. Logo, há um condicionamento visível do direito ao processo produtivo estabelecido nesse espiral dialético. A relação social jurídica constituída, o Estado e a Constituição são produtos forjados nas relações sociais históricas.

Como a dialética social do direito faz uma interpretação jurídica a partir de um referencial ético que direciona a análise desde as classes e grupos

\footnotetext{
99 "Direito, repito, é processo dentro do processo histórico, e, como este, um processo dialético. É a expressão particular e inconfundível do processo histórico, no ângulo em que se traça a esfera das liberdades em coexistência, segundo o padrão atualizado e militante da Justiça Social (...)" (LYRA FILHO, 1982, p.44).
} 
sociais oprimidos e explorados da sociedade, podemos supor que ela vislumbra uma perspectiva de totalidade que insere o conceito de exterioridade, uma vez que inclui a classe subalterna latino-americana como sujeito histórico. Contudo, Enrique Dussel explicita essa análise concebendo uma categoria que identifica questões históricas concretas, as quais extrapolam as relações sociais no âmbito do capitalismo e necessitam ser superadas através da analética.

O movimento dialético, para Dussel, promove a "negação da negação" dentro da estrutura da Totalidade vigente, com o propósito de analisar a estrutura desde a articulação de variados campos que the dão formato. Mas, o autor insiste que a realidade não se resume à totalidade, pois essa representa aquilo que é sistêmico. "A realidade social é conformada, portanto, pela Totalidade concreta e pela Exterioridade filosófica, que é o plano onde se situa a Alteridade, do Outro excluído pela Totalidade vigente." (DIEHL; LEONEL JúNIOR, 2012, p. 800)

A categoria própria da analética é a exterioridade, sendo fundamental sua interação com a totalidade, alterando assim seus campos ônticos, inclusive o jurídico. Justamente, porque a forma que se concebe a totalidade, parte das vezes, ignora a exterioridade, que na análise de Dussel é composta pelas classes espoliada e trabalhadora da América Latina, distintas em alguns aspectos concretos da composição subalterna de outros locais no mundo. $O$ método analético parte de uma perspectiva crítica e de superação do método dialético negativo, subsumindo-o e completando-o (DUSSEL, 2011 , p. 240). A analética possibilita que através da categoria exterioridade seja forjada nova totalidade, incorporando então esse novo elemento.

Mesmo que supuséssemos que ao referir a uma ontologia dialética do direito, Lyra Filho estaria limitando a análise do saber jurídico à totalidade estabelecida, sem considerar o Outro contido na exterioridade filosófica, por aparentemente ater-se à lógica da luta de classes; Dussel, certamente permite que as alteridades negadas pela totalidade vigente sejam resgatadas, tanto as regidas diretamente pela produção capitalista, no âmbito direto da luta de 
classes, quanto àquelas que são destruídas pelo avanço do capital e foram silenciadas pela modernidade ocidental. (DIEHL; LEONEL JÚNIOR, 2012, p. 801).

Assim, o momento analético ${ }^{100}$ permitirá analisar as variáveis apresentadas pela exterioridade em âmbito prático, seja na superação da dominação política, erótica, pedagógica e fetichista. ${ }^{101}$

\begin{abstract}
El momento analéctico es la afirmación de la exterioridad: no es solo negación de la negación del sistema desde la afirmación de la totalidad. Es superación de la totalidad pero no sólo como actualidad de lo que está en potencia en el sistema. Es superación de la totalidad desde la trascendentalidad interna o la exterioridad, el que nunca ha estado dentro. Afirmar la exterioridad es realizar lo imposible para el sistema (no había potencia para ello); es realizar lo nuevo, lo imprevisible para la totalidad, lo que surge desde la libertad incondicionada, revolucionaria, innovadora. (DUSSEL, 2011, p. 240-241).
\end{abstract}

Desse movimento se enxerga caminhos para a emancipação e libertação dos trabalhadores/as e dos povos latino-americanos do ranço colonial e a dominação classista hegemônica. Um direito da libertação não é uma questão meramente teórica, mas está ligada a uma "práxis concreta, entendida como práxis de libertação da Exterioridade em relação à Totalidade vigente, dominadora." (DIEHL; LEONEL JÚNIOR, 2012, p. 802). Em Estados como Venezuela, Bolívia e Equador, um desenho institucional diferenciado já é apresentado e estabelece sinais peculiares no sistema de direitos que emergem da subjetividade de trabalhadores/as e oprimidos históricos, que logram constituir uma hegemonia política resultantes da luta popular. Assim, os

\footnotetext{
100 "En la analéctica no es suficiente la teoría. En la ciencia y la dialéctica lo especulativo es lo constitutivo esencial. En la analéctica, por cuanto es necesario la aceptación ética de la interpelación del oprimido y la mediación de la praxis, dicha praxis es su constitutivo primordial, primero, condición de posibilidad de la comprensión y el esclarecimiento, que es el fruto de Haber efectiva y realmente accedido a la exterioridad (único ámbito adecuado para el ejercicio de la conciencia crítica)" (DUSSEL, 2011, p. 239-240).

${ }^{101}$ Ver ponto 2.1.2.
} 
novos processos constituintes ganham uma relevância pela nova composição de sujeitos que participam da elaboração, permitindo o surgimento de "novos direitos" ou direitos que extravasam a lógica formal liberal-burguesa de concepção do direito.

Assim, incorporando a analética desenvolvida por Dussel à dialética social do direito de Roberto Lyra Filho, teremos a analética social do direito. Essa "traz consigo ferramentas para compreender o processo complexo de intersecção do campo jurídico com os demais campos sociais existentes" (DIEHL; LEONEL JÚNIOR, 2012, p. 804). Esse instrumento deve analisar a incidência da relação jurídica a partir do modo de produção hegemonizado no mundo e seus efeitos para as vítimas sistêmicas, que desde a capacidade transformadora da classe subalterna, possa realizar uma nova totalidade. Dessa forma é aberta a possibilidade de rompimento com a colonialidade do saber jurídico, pois o método de análise incide em problemas, os quais podem ser superados por "novos" sujeitos de direitos, na elaboração de um novo sistema de direitos.

\subsection{O Novo Constitucionalismo Latino-americano}

$\mathrm{Na}$ última década, uma série de experiências institucionais e movimentos teóricos convergentes, ocorridos em alguns países da América Latina, conduziu à descrição de inovações políticas e jurídicas introduzidas nesses contextos como expressões de um "novo constitucionalismo latinoamericano" (MAGALHÃES, 2009). Essa denominação aponta para o fato de que essa série de reflexões e experimentos institucionais ocorre em um momento no qual se questiona e se busca superar a herança constitucional hegemônica, descrita como eurocêntrico-estadunidense, liberal, colonizadora e monista (LEONEL JÚNIOR, 2014a, p. 96). O reconhecimento de que a 
experiência histórica dos países latino-americanos não é devidamente explicada pelas teorias hegemônicas, conduziu vários pensadores a buscarem uma compreensão que articule adequadamente as pluralidades que marcam essas experiências históricas. Esses elementos, que foram, até então, marginalizados pela adoção de marcos teóricos e modelos políticos que não as levavam em conta, ganham reconhecimento a partir das lutas sociais e inspiram uma série de transformações institucionais.

Esse movimento não afirma a impossibilidade de diálogo com outras experiências, nem o absoluto repúdio às teorias constitucionais anteriores, tendo em vista que o estabelecimento de comparações com outros modelos contribui para todo processo pedagógico. Mas, ele afirma que as peculiaridades da experiência latino-americana deveriam ser tematizadas de modo explícito, para que as abordagens constitucionais e os projetos políticos subjacentes a elas enfrentem os problemas fundamentais da sociedade à qual ela será submetida. Cabe então questionar: quais são os problemas, antes ocultos ou marginalizados, que os novos arranjos constitucionais buscaram resolver nesse último período?

A elaboração de textos constitucionais, como qualquer processo social, resulta da conformação de um processo político peculiar, que é permeado pela correlação das forças sociais presentes. $O$ texto resultante desses processos constituintes é uma estrutura criada que, por si só, limita o poder do povo, mesmo afirmando poder a este. Essa limitação do poder absoluto do povo deve constituir-se a partir de elementos legitimados com um determinado projeto de sociedade, o qual poderá atender aos anseios e necessidades genuinamente populares, concebidos a partir de um recorte de classe. O processo constituinte permite a materialização de um cenário em que as forças sociais, puxadas por alguma vanguarda política emanada por um bloco histórico, são apresentadas e exercem poder perante aquela dinâmica social em determinado período.

$\mathrm{Na}$ realidade da América Latina, as novas Constituições podem marcar a possibilidade de transição de projetos em que grupos historicamente marginalizados assumem um protagonismo político. 
No entanto, estas inovações constitucionais não ocorrem por acaso. Um olhar para a evolução da história constitucional e para as movimentações políticas, sobretudo em países latino-americanos, trazem constantes sinais de mudança.

2.3.1. Da perspectiva histórica constitucional da América até o novo constitucionalismo latino-americano

O que é concebido como Constituição na atualidade, surge a partir das Revoluções Liberais do fim do século XVIII. Os pensadores modernos abandonam as utopias antigas, centradas no estabelecimento de estruturas voltadas à realização de uma determinada concepção de bem, e buscam estabelecer instituições políticas em que algumas concepções divergentes possam conviver, sem que nenhuma possa buscar a exclusão das demais. Essa articulação desloca paulatinamente para o campo da política uma série de questões que eram respondidas a partir de critérios pretensamente objetivos de moralidade e justiça, fazendo com que elas pudessem ser legitimamente enfrentadas por meio de critérios utilitários de articulação de interesses: a organização das famílias, da propriedade, do governo. Essa redução da afirmação heterônoma dos padrões valorativos tradicionais envolveu a ampliação de mecanismos autônomos de criação legislativa, o que acentuou o papel da lei e das políticas públicas, referidas a uma autonomia coletiva da unidade política (normalmente interpretada como a soberania do povo), que poderia estabelecer os seus próprios padrões de organização política.

Esse movimento gerou uma abertura bastante relativa na incorporação de concepções divergentes, tendo em vista que logo se articulou a ideia liberal de que as decisões políticas precisariam respeitar os valores tradicionais, compreendidos como direitos naturais. $O$ fruto desse movimento foi a 
afirmação conflituosa de uma primazia política da soberania popular juntamente com uma primazia jurídica dos direitos naturais, que conduziu à valorização de documentos constitucionais nos quais se poderia afirmar miticamente que a soberania popular se comprometia com direitos naturais (anulando o conflito potencial entre esses elementos) e estabelecia as regras básicas do funcionamento do sistema político. Nesse contexto, a concentração absoluta dos poderes políticos em uma instituição política central fez com que se esgotasse a estratégia hobbesiana de conferir amplos poderes para um governo central capaz de garantir a unidade política, tendo em vista que a estabilidade desse governo centralizado passava a depender de sua capacidade de organizar os vários grupos sociais em um sistema de coordenação (relativamente) pacífica de interesses.

Como o exercício do governo passou a ser decorrente de processos de sufrágio, a estabilidade social não mais poderia se assentar nos compromissos governamentais de afirmar uma concepção unitária de bem, o que permitiu um retorno às estratégias medievais de que a lei da terra (law of the land) e 0 direito comum (common law) se impunha a todos, inclusive aos governantes. As estratégias de estabilização social fundadas na reafirmação da unidade da lei, e não na unidade do governo, implicaram uma busca pela construção de instituições impessoais, que pudessem funcionar adequadamente independentemente de quem ocupasse os cargos de governo, promovendo uma organização política que simultaneamente atendesse aos interesses dos cidadãos e aos padrões objetivos de justiça. A Constituição é o instrumento que norteará o sistema jurídico e político dos Estados, justamente por ser a ferramenta mais estável e rígida desse arranjo em que se define mediante regras rígidas e estáveis uma arena política em que os vários interesses sociais possam ser articulados, mas sem pretensamente violar um quadro de direitos considerados indisponíveis.

O modelo do Estado e das Constituições modernas surge a partir do advento da Revolução Francesa e da independência dos Estados Unidos. Os pilares de sustentação desse constitucionalismo são, acima de tudo, a preservação de direitos civis e políticos, além da propriedade. A sociedade é 
concebida tendo a figura do indivíduo como unidade básica, de modo que o "corpo social" não é mais percebido como uma união de vários "órgãos" formados pelas várias corporações, mas por uma união autônoma de indivíduos isolados. Essa configuração torna o Estado a única entidade que pode gerar direitos, pois são abolidos os direitos de classes, grupos e estamentos: a soberania popular implica que, somente o povo politicamente organizado pode definir regras jurídicas obrigatórias, o que é um passo importante na dissolução dos direitos segmentados que marcavam a ordem jurídica feudal e que foram recepcionados pelo "antigo regime". Entretanto, a supressão dos direitos específicos em nome da garantia de um direito unificado não significa que certos direitos previstos para todos tenham como beneficiários determinados grupos sociais. Em especial, a legislação constitucional, que exclui a propriedade e os direitos econômicos da regulação política, beneficia as pessoas que têm uma posição econômica privilegiada e que poderiam ser afetadas por uma redistribuição política das riquezas.

Considerando que a principal minoria política a ser defendida era justamente a dos que tinham propriedades (MADISON; HAMILTON; JAY, 1993), a Constituição dos Estados Unidos fixa a forma que será de todas as Constituições contemporâneas: aliar estrutura de Estado (ou seja, de monopólio da soberania por uma instituição política central) à declaração de direitos (que impede que as instituições políticas modifiquem certas estruturas consideradas naturalmente justas, especialmente as regras que definem a distribuição da propriedade e o funcionamento da economia).

Desde o século XIX, os momentos de crise aguda que geram rearranjos institucionais intensos, implicando inovações em uma determinada ordem política, tipicamente geram a produção de um novo texto constitucional, que reflita a nova ordem e as novas narrativas hegemônicas. Essas modificações, tipicamente referidas como exercícios do poder do povo, de autogoverno, cristalizam novas formas de organização institucional e inauguram novos equilíbrios. 
Na América Latina, as Constituições escritas surgiram juntamente com os movimentos de independência dos países e refletiram determinadas peculiaridades a cada processo constitucional. Todas elas utilizaram a Constituição Estadunidense como modelo, especialmente no estabelecimento de modelos presidencialistas, embora a aplicação dos modelos dos Estados Unidos a contextos sociais bastante diversos tenha resultado em instituições que desempenham papéis bastante diferentes do modelo original. Juntamente com o modelo estadunidense, importava-se a matriz filosófica constitucional liberal, individualista e elitista, mas esse liberalismo era temperado pelo fato de que, como ressalta Gargarella (2009, p.15), os movimentos constitucionais da América Latina eram inspirados por um conservadorismo de matriz religiosa bastante diverso do princípio liberal de neutralidade religiosa. Além disso, a adaptação do presidencialismo aos países da América Latina, diante da realidade regional do século XIX, gerou um Poder Executivo forte, autoritário e dominado pelos conservadores em um sistema de freios e contrapesos (checks and balances) bastante débil, se comparado ao do próprio Estados Unidos.

Ressaltam-se naquele contexto, Constituições que garantiam direitos e liberdades individuais, um sistema representativo com o propósito de afastar os cidadãos dos representantes, a criação de instituições conservadoras para a garantia de manutenção do status quo como o Senado entre outras medidas. Mesmo com a independência política formal dos Estados na América Latina, há uma permanência de práticas do Estado colonial para o pós-colonial nos variados âmbitos econômico, social, etc ${ }^{102}$.

Certamente, diversos pontos deste paradigma constitucional modificaram-se ao longo da história e, no contexto atual, os mecanismos de exclusão ou inferiorização política das populações indígenas, negras e pobres tem sido objeto de questionamento crescente. Neste contexto, o jurista argentino Roberto Gargarella, traz indagações interessantes para o debate, o

\footnotetext{
102 "Os projetos de emancipação nacional, herdeiros do projeto dos crioulos que lideraram o "povo" latino-americano no processo da emancipação contra as metrópoles do século XIX, fundaram o estado-nação moderno. Houve dificuldade em integrar o "projeto" das etnias indígenas e das culturas afro-latino-americanas, das culturas populares no projeto de libertação futuro latino-americano" (DUSSEL, 1993, p.169).
} 
que concebe como uma diferenciada "filosofia pública atual ${ }^{103 ", ~ q u e ~ n a ̃ o ~}$ reproduz identicamente a filosofia pública dos anos fundacionais do constitucionalismo.

No deberíamos entonces, y en consecuencia, modificar o reajustar nuestras instituciones, para tornarlas, por caso, más permeables al debate público; para estrechar los lazos entre representantes y representados; para reducir el impacto del control judicial sobre las políticas mayoritarias; para repensar el rol del Senado; para revisar la función del veto Ejecutivo; para reajustar los equilibrios entre las distintas ramas del poder? (GARGARELLA; COURTIS, 2009, p. 5).

No entanto, poucos países da América Latina trazem características condizentes com esta "filosofia pública atual" em suas Constituições. Observase que, em geral, não houve um rechaço às características eminentemente liberais e individualistas reinantes, que se manifestam principalmente na impossibilidade de uma regulação política da economia e na ausência de reconhecimento da existência de ordens jurídicas plurais dentro de uma mesma organização nacional. Nas últimas décadas, o movimento mais típico das reformas constitucionais acerca da ordem política foi uma ampliação da possibilidade de reeleição, satisfazendo interesses de curto prazo em que grupos políticos buscam a manutenção do poder, fenômeno que ocorreu em um mesmo período histórico no Brasil com Fernando Henrique Cardoso, na Argentina com Carlos Menem, no Peru com Alberto Fujimori, na Colômbia com Álvaro Uribe e na Venezuela com Hugo Chávez.

Em um primeiro momento histórico observou-se grupos com ideais políticos conservadores e até, em certa medida, diferenciadas das propostas dos liberais. Gabriel García Márquez, em seu clássico literário, Cem anos de solidão, traz uma passagem elucidativa, quando o Sr. Apolinar Mascote, um

\footnotetext{
103 "La pregunta resulta pertinente porque nuestra filosofía pública actual puede representar muchas cosas, pero claramente no es idéntica $-y$, podríamos agregar, parece ser bastante diferente, en general- a aquella que resultaba predominante en los años fundacionales del constitucionalismo" (GARGARELLA; COURTIS, 2009, p. 4-5).
} 
conservador, dá lições esquemáticas a Aureliano Buendía, o qual despertava a curiosidade pelas ideias liberais.

Os liberais, dizia, eram maçons; gente de má índole, partidária de enforcar os padres, de instituir o casamento civil e o divórcio, de reconhecer iguais direitos aos filhos naturais e aos legítimos, e de despedaçar o país num sistema federal que despojaria de poderes a autoridade suprema. Os conservadores, ao contrário, que tinham recebido o poder diretamente de Deus, pugnavam pela estabilidade da ordem pública e pela moral familiar; eram os defensores da fé de Cristo, do princípio de autoridade, e não estavam dispostos a permitir que 0 país fosse esquartejado em entidades autônomas (GARCÍA MARQUEZ, 1967, p. 96).

Os conservadores, como exemplificado na literatura latina de García Márquez, rechaçavam a perspectiva de laicidade do Estado, devido à grande influência da igreja católica, durante a colonização espanhola e portuguesa. Assim, a práxis política pautava-se pelo autoritarismo, negador das muitas liberdades individuais. Contudo, o contexto latino-americano aproxima estes dois grupos, os quais pactuam o poder que possuem elaborando as Constituições vindouras a partir de meados do século $\mathrm{XIX}^{104}$.

Ao longo do século XIX, a reprodução da estrutura e das disposições constitucionais na América Latina ressaltavam características que aprofundaram a subserviência e o anacronismo dos modelos aqui implementados. Inicialmente cabe-nos ressaltar que os povos que habitavam essas terras deveriam ser destacados para qualquer análise política vindoura. Algo que o constitucionalismo reproduzido na América Latina, ao longo do século XIX, não se preocupou. A jurista peruana Raquel Z. Yrigoyen Fajardo pontua de modo esclarecedor as principais consequências do então modelo constitucional tradicional.

\footnotetext{
104 "Liberales y conservadores, por caso, lograron pactar y colaborar en la redacción de las nuevas Constituciones de mediados del siglo XIX, gracias al enorme espacio de coincidencias existente entre ambos proyectos (ambos repudiaban el mayoritarismo político; ambos proponían una defensa firme del derecho de propiedad; ambos coincidieron sin mayores dificultades en la implementación de políticas económicas anti-estatistas)" (GARGARELLA; COURTIS, 2009, p. 7).
} 
En el siglo XIX, el proyecto criollo de sujeción indígena del horizonte del constitucionalismo liberal se expresó bajo tres técnicas constitucionales: a) asimilar o convertir a los indios en ciudadanos intitulados de derechos individuales mediante la disolución de los pueblos de indios-con tierras colectivas, autoridades propias y fuero indígena- para evitar levantamientos indígenas; b) reducir, civilizar y cristianizar a los indígenas todavía no colonizados, a quienes las Constituciones llamaron "salvajes", para expandir la frontera agrícola; y c) hacer la guerra ofensiva y defensiva contra las naciones indias -con las que las coronas habían firmado tratados y a las que las Constituciones llamaban "bárbaros"- para anexar sus territorios al Estado (2011, p. 140).

Nesse mesmo contexto histórico-político, o mito da neutralidade constitucional advém com o modelo liberal, conforme já citado ${ }^{105}$. Esse debate surge com maior vigor, em meados do século XIX na Europa, em que as parcelas políticas conservadoras defendiam um aporte estatal comprometido com a religião. Os grupos liberais rechaçavam essa proposta elencando a pretensa neutralidade como fundamental nas Constituições.

Assim, havia um enfrentamento entre constitucionalistas conservadores e constitucionalistas liberais com fins de implementarem o projeto político que Ihes interessavam. Os países da América Latina com o poder da igreja católica e a força das ideias liberais advindas com os processos de independência, tecem Constituições que sustentavam o catolicismo como religião oficial e, ao mesmo tempo, garantiam a tolerância religiosa ${ }^{106}$. Apesar de uma estrutura liberal, os ideais eram influenciados por tendências conservadoras, o que as tornavam ambíguas. Certamente, existiam outras razões políticas que fundamentavam essa fusão, como a intencionalidade em repelir o avanço de grupos e ideias socialistas que crescia no mundo. Assim, a neutralidade constitucional "caia por terra" tanto por sustentar um Estado com religião

\footnotetext{
${ }^{105}$ Cf. Ponto 2.2.1

${ }^{106}$ Cf. Constituição Argentina de 1853.
} 
específica ou mesmo aceitando uma "moral" tolerante liberal com claras intencionalidades políticas.

De toda forma, o mito da neutralidade forjou-se como poderoso discurso que, muito além de pautar um Estado laico, garantiam os fundamentos filosóficos e o poder político entre essa composição de classes liberalconservadora. A pauta das liberdades individuais, do livre mercado, do direito de propriedade, do respeito aos contratos, ganharam força com esse discurso da neutralidade, como se o Estado não atendesse a quaisquer desses interesses. Os questionamentos que Roberto Gargarella e Courtis fazem, ilustra bem os impactos desse mito;

De modo similar, en qué sentido podemos aceptar el calificativo de neutralidad, para referirnos a Constituciones que consagran fuertes protecciones a los contratos y a la propiedad; que desalientan la expropiación; que consagran como derechos básicos a la libertad de comercio, de navegación, la libertad de circulación de productos? Sin embargo, otra vez, cláusulas como las señaladas son referidas como cláusulas distintivas de una Constitución neutral (2009, p. 16).

Muito além do aspecto religioso, o Estado compromete a neutralidade no momento que cria condições concretas para o desenvolvimento da economia capitalista atrelada à hegemonia política liberal. Este não pode ser declarado neutro ao defender liberdades individuais frente às liberdades coletivas ou a liberdade de mercado frente à economia planificada com a intervenção do Estado. Não há neutralidade nessas posturas. Há uma ideologia que suporta esse posicionamento e a defesa dessa mítica neutralidade constitucional.

Para além do que a mera teoria liberal apresentava, uma diferenciada modelação constitucional aparece com o tom reformista em decorrência da crise econômica de 1929 e o estopim de Revoluções Socialistas no mundo. Esses elementos políticos possibilitaram um viés garantidor aos direitos trabalhistas e sociais, ampliação dos fundamentos da cidadania, os quais já 
apareciam na Constituição Mexicana de 1917, reconhecida como portadora de um constitucionalismo social, fruto de uma importante luta política naquele país. Enquanto os países centrais do sistema-mundo, como os Estados Unidos e parte da Europa, desenvolviam o Estado de Bem Estar Social, sobretudo, ao fim da segunda guerra mundial como forma de impulsionar a economia.

A realidade depreendida era da não participação e da prática política opressora e violenta contra os povos originários. Mesmo em uma experiência constitucional proveniente de uma Revolução social como no caso do México, ainda persistira uma prática assimilacionista diante dos povos indígenas que lá habitavam. Buscava-se integrar o indígena ao Estado e ao mercado sem romper com o monismo jurídico e a identidade do Estado-nação, o que ficou conhecido como constitucionalismo social integracionista (FAJARDO, 2011, p. 140).

$\mathrm{Na}$ América Latina, a aliança liberal-conservadora começa a dar mostras de esgotamento quando se iniciou um processo de industrialização. Devido à crise econômica nos países centrais e o acometimento das duas guerras mundiais, houve um contexto internacional que favoreceu uma industrialização primária, seja para o fornecimento de produtos com pouco valor agregado aos países de economia central, seja para garantir a produção de alguns bens essenciais em determinados países da América Latina. Essa reorganização da economia colocava em risco a manutenção de certos modos tradicionais de organização social, pois a industrialização engendra movimentos de urbanização, de educação voltada a garantir uma mão-de-obra mais especializada e de relações trabalhistas mais reguladas. No século XIX, os processos de industrialização engendraram de forma geral um fortalecimento do liberalismo, mas no início do século XX essa ligação não era imediata, porque os sistemas corporativos se apresentavam como uma alternativa política ao ideário liberal. Em vez da radical individualidade do liberalismo, os sistemas corporativos fortaleciam órgãos intermediários, como os sindicatos, de modo que a participação política não fosse dissolvida na manifestação de preferências individuais, que poderiam levar a uma grande instabilidade. 
As reformas constitucionais, que seguiram essa modificação políticoeconômica, revelam as tensões entre liberalismo e corporativismo, como é o caso especialmente da Constituição Brasileira de 1934, que marcou um equilíbrio instável entre esses dois modelos. Ao longo da década de 1930, as reivindicações sociais ligadas ao crescimento do proletariado urbano foram incorporadas às Constituições: brasileira de 1937, boliviana de 1938 e cubana de 1940, entre outras. Os direitos sociais previstos, de forma inédita, de acordo com José Murilo de Carvalho, "garantem a participação no governo da sociedade, a participação na riqueza coletiva. Eles incluem o direito à educação, ao trabalho, ao salário justo, à saúde, à aposentadoria" (CARVALHO, 2002, p. 10). As mudanças econômicas e constitucionais propiciavam mudanças de posturas políticas, mas estas não apontaram para as estruturas políticas liberais de checks and balances e de governos limitados, e sim para governos fortes, capazes de introduzir as mudanças sociais necessárias e para atuar de acordo com os ditos interesses do povo.

No caso brasileiro, período do Governo de Vargas, as garantias de direitos sociais eram exemplificadas com políticas concretas como na "criação do Ministério do Trabalho, Indústria e Comércio, maior assistência social e com a Consolidação das Leis do Trabalho em 1943" (MORAES; LEONEL JÚNIOR, 2011, p. 299). Mesmo com o rearranjo na postura política, os países da América Latina, diferentemente dos países de economias centrais, não efetivaram as políticas de um Estado propiciador de bem estar social. As "demandas sociais nunca foram elencadas como estruturais para um governo. Logo, o país contou tão só com resquícios de políticas públicas e sociais insuficientes para um provimento das necessidades básicas da população" (MORAES; LEONEL JÚNIOR, 2011, p. 300).

A concepção da Constituição, nesse período, mantem um rearranjo que busca dar conta das pressões sociais da época e da própria dinâmica liberal, ora fragilizada, mas ainda manifestada através de uma linguagem universalista de direitos. Agregam-se alguns novos direitos, mas não se perde o foco sistêmico das garantias individuais, do direito de propriedade e a consequente concentração dos meios de produção. 
No entanto, para alguns juristas, essas modificações constitucionais após a segunda guerra mundial viabilizam politicamente uma nova fase, conhecida por neoconstitucionalismo.

El neoconstitucionalismo pretende explicar un conjunto de textos constitucionales que comiezan a surgir después de la segunda guerra mundial y sobre todo a partir de los años setenta del siglo XX. Se trata de Constituciones que no se limitan a establecer competencias o a separar a los poderes públicos, sino que contienen altos niveles de normas "materiales" o sustantivas que condicionan la actuación del Estado por medio de la ordenación de ciertos fines y objetivos. Ejemplos representativos de este tipo de Constituciones lo son la española de 1978, la brasileña de 1988 y la colombiana de 1991 [...] (CARBONELL, 2007, p. 9-10).

Assim, esse período histórico é marcado pelo advento desta nova forma de concepção constitucional, o qual atribui um papel de centralidade da Constituição, em um momento político que representaria o final de um período autoritário e ditatorial na América Latina.

O neoconstitucionalismo dá maior ênfase às interpretações jurídicas ponderadas por princípios constitucionais. A argumentação jurídica alimentada por elementos de cunho moral sustentam a construção de legitimidade das decisões. Dessa forma, buscou-se dar passos para além do formalismo positivista, até então, vigente.

Não se trata, por ora, de mera subsunção da norma jurídica ao fato, tal como prevê a doutrina positivista, mas a partir da influência das teorias póspositivistas de Ronald Dworkin, e sobretudo, Robert Alexy, um modelo pautado pela ponderação ${ }^{107}$ de princípios advindos da Constituição para a análise dos casos.

O caráter de imperatividade constitucional também ganha destaque, e a Constituição, para alguns juristas, passa a ser concebida como uma norma

107 "O objetivo desse sopesamento é definir qual dos interesses - que abstratamente estão no mesmo nível - tem maior peso no caso concreto." (ALEXY, 2008, p. 95). 
jurídica. Em sendo norma jurídica, a Constituição, para além de um conteúdo moral, passa a ter força mandamental, de comando, não mais sentido meramente recomendativo. Aliada a essa imperatividade, está a busca por efetividade dos mandamentos constitucionais. Há quem atribua a essas novas características constitucionais (BARROSO, 2007), status de uma transformação paradigmática, como explicita o professor Luis Roberto Barroso, ao tratar da Constituição brasileira.

[...] o movimento pela efetividade promoveu, com sucesso, três mudanças de paradigma na teoria e na prática do direito constitucional no país. No plano jurídico, atribuiu normatividade plena à Constituição, que passou a ter aplicabilidade direta e imediata, tornando-se fonte de direitos e obrigações. Do ponto de vista científico ou dogmático, reconheceu ao direito constitucional um objeto próprio e autônomo, estremando-o do discurso puramente político ou sociológico. E, por fim, sob o aspecto institucional, contribuiu para a ascensão do Poder Judiciário no Brasil, dando-lhe um papel mais destacado na concretização dos valores e dos direitos constitucionais (2005, p. 76).

Ao que parece essas modificações não consistem em mudanças tão profundas no constitucionalismo. Realmente, os avanços históricos são nítidos, mas ainda insuficientes para uma transformação paradigmática do direito ou até mesmo do modelo constitucional, o qual ainda fundamenta uma estrutura moderna, liberal e positivista do direito. Ademais, o neoconstitucionalismo ainda não garantiu a soberania plena dos Estados nacionais, ainda reféns das instituições econômicas transnacionais (LEONEL JÚNIOR, 2014b).

Assim, o neoconstitucionalismo apresenta características liberais claras como: o fortalecimento da ideia de jurisdição constitucional, controle contramajoritário das Cortes e Tribunais Constitucionais e da própria representação política. Por isso mesmo, ele se mostra pouco apto para visibilizar as experiências, conhecimentos teóricos e práticos de povos excluídos como os negros/as e indígenas componentes dos Estados latino-americanos. O projeto unificador do liberalismo deixa pouco espaço para que a irredutível 
multiplicidade seja reconhecida e articulada em um sistema multicêntrico, em vez de reduzida a um sistema centralizado e concentrado de princípios constitucionais. O fortalecimento do judiciário, como instância interpretativa garantidora da unidade sistêmica do direito, não estabelece âmbitos de articulação autônoma de unidades políticas plurais, mas reforça o padrão liberal de monopólio do direito pelo Estado.

Para Roberto V. Pastor e Rubén M. Dalmau, o neoconstitucionalismo restringe-se a recuperar o conceito e a força determinante da Constituição perante o ordenamento. "Em definitivo, o neoconstitucionalismo pretende, sem ruptura, distanciar-se dos esquemas do positivismo teórico e converter o Estado de Direito em Estado Constitucional de Direito" (Tradução Livre) (MARTÍNEZ DALMAU; VICIANO PASTOR, 2012, p. 3).

Os dois autores citados, ainda optam por diferenciar 0 neoconstitucionalismo, do que caracterizam como "nuevo constitucionalismo", expressão a qual adequaremos ao português no decorrer da análise como "novo constitucionalismo". De acordo com eles, além da primazia jurídica constitucional trazida pelo neoconstitucionalismo, o novo constitucionalismo adere outro elemento, a necessidade da legitimidade democrática da Constituição $^{108}$. Esse elemento dotará o constitucionalismo de maior possibilidade de avanços populares empreendidos, resgatando a referência da soberania popular como alicerce do poder constituído.

[...] el nuevo constitucionalismo busca analizar, en un primer momento, la exterioridad de la constitución; es decir, su legitimidad, que por su propia naturaleza sólo puede ser extrajurídica. Posteriormente - como consecuencia de aquélla - interesa la interioridad de la constitución, con particular referencia - y en ese punto se conecta con los postulados neoconstitucionalistas - a su normatividad. Desde los axiomas democráticos, el fundamento de la constitucionalización del ordenamiento jurídico sólo puede encontrarse en que la

\footnotetext{
108 “(...) el nuevo constitucionalismo asume las posiciones del neoconstitucionalismo sobre la necesaria impregnación constitucional del ordenamiento jurídico pero su preocupación no es sólo la dimensión jurídica de la Constitución sino, en un primer orden, su legitimidad democrática (...)". (MARTÍNEZ DALMAU; VICIANO PASTOR, 2010b, p. 18).
} 
constitución es el mandato del constituyente, y refleja su voluntad (MARTÍNEZ DALMAU; VICIANO PASTOR, 2010a, p. 4-5).

Roberto Viciano Pastor e Rubén Martínez Dalmau apresentam uma proposta em que entendem o novo constitucionalismo como um processo que complementaria os aspectos faltantes do neoconstitucionalismo, incluindo assim a legitimidade democrática como um elemento com o patamar de importância fundamental na nova concepção constitucional. Esse fortalecimento da dimensão democrática do constitucionalismo implica uma redução do seu caráter liberal, alterando fundamentalmente o equilíbrio em que os governos deveriam monopolizar a articulação dos interesses sociais de modo a garantir a unidade, a estabilidade e o respeito aos direitos naturais.

O movimento de ruptura desse monopólio estatal do direito veio a se tornar explícito na década de 80 do século XX, quando no corpo constitucional latino-americano começam a ser enfatizadas as características relacionadas a uma multiculturalidade e a uma pluriculturalidade ${ }^{109}$ proveniente do Estado, como já destacado por Raquel Z. Yrigoyen Fajardo. Essa resposta representa uma crítica radical ao liberalismo na medida em que, em vez de apontar para a unificação dos direitos em um sistema unificado (e que refletia os direitos construídos na tradição liberal de matriz europeia), aponta para a necessidade de que os vários sistemas existentes sejam respeitados e articulados.

O aspecto da multiculturalidade se fortalece com a demanda de direitos indígenas e o reconhecimento da identidade cultural e de direitos individuais e coletivos. Esse termo admite a existência de diversas culturas singulares, que

\footnotetext{
109 "Lo pluricultural y multicultural son términos descriptivos que sirven para caracterizar la situación diversa e indicar la existencia de múltiples culturas en un determinado lugar planteando así su reconocimiento, tolerancia y respeto. El «multi» tiene sus raíces en países occidentales, en un relativismo cultural que obvia la dimensión relacional y oculta la permanencia de desigualdades e inequidades sociales. Actualmente es de mayor uso global, orientando políticas estatales y transnacionales de inclusión dentro de un modelo de corte neoliberal que busca inclusión dentro del mercado. El «pluri», en cambio, es término de mayor uso en América del Sur; refleja la particularidad y realidad de la región donde pueblos indígenas y negros han convivido por siglos con blanco-mestizos y donde el mestizaje y la mezcla racial han jugado un papel significante" (WALSH, 2008, p.140).
} 
não necessariamente possuem algum vínculo, em uma lógica cultural dominante em vigência, ou seja, não é uma construção que parta diretamente desses povos e rompa com uma cultura hegemônica elitista, que ainda mostrase dominante. A Constituição guatemalteca de 1985, nicaraguense de 1987 e brasileira de $1988^{110}$ são bons exemplos desse fenômeno.

Já, no início da década de 90, algumas Constituições passam a reconhecer o Estado como Pluricultural ${ }^{111}$. Esse termo é expresso para garantir a convivência de culturas em um território comum, mesmo que não pressuponha um equilíbrio entre elas. Neste período inicia-se o rompimento com a identidade monista estatal, em que só validara normas provenientes dos órgãos soberanos do Estado. Ainda trata-se de momento histórico em que as Constituições agregam elementos trazidos na Convenção 169 da OIT estabelecendo direitos aos povos indígenas e tribais em 1989. Esse é o contexto em que começa a ser estabelecida uma alternativa à estratégia hobbesiana de que a única forma de garantir a estabilidade política é a criação de um governo centralizado forte, capaz de impor a unidade por meio da afirmação de um direito unificado. Em vez de uma unidade concentradora de poder, o reconhecimento de que é possível um sistema que não seja de subordinação absoluta ao centro, mas de coordenação policêntrica de unidades políticas relativamente autônomas.

${ }^{110} \mathrm{O}$ artigo 216 da Constituição Brasileira demonstra bem o reconhecimento desses direitos.

"Art. 216. Constituem patrimônio cultural brasileiro os bens de natureza material e imaterial, tomados individualmente ou em conjunto, portadores de referência à identidade, à ação, à memória dos diferentes grupos formadores da sociedade brasileira, nos quais se incluem:

I - as formas de expressão;

II - os modos de criar, fazer e viver;

III - as criações científicas, artísticas e tecnológicas;

IV - as obras, objetos, documentos, edificações e demais espaços destinados às manifestações artístico-culturais;

$V$ - os conjuntos urbanos e sítios de valor histórico, paisagístico, artístico, arqueológico, paleontológico, ecológico e científico."

111 Nesta seara de influência foram pautadas diversas Constituições da América Central e América do Sul, como Colômbia em 1991, México em 1992, Paraguai em 1992, Peru em 1993, Argentina em 1994, Equador em 1996 e 1998 entre outras. 
A adoção de maiores garantias e direitos indígenas, em um universo multicultural e de reconhecimento da pluriculturalidade do Estado são implementados constitucionalmente no mesmo contexto de ascenso das políticas neoliberais ${ }^{112}$. As reformas que se sucederam diante da nova dinâmica política neutralizaram os possíveis avanços de uma maior visibilidade para os sujeitos originários da América Latina, o caso do Peru exemplifica bem o impacto desta crescente neoliberal e a dificuldade em validar direitos frente ao quadro político colocado.

(...) la Constitución peruana de 1993, si bien reconoció por un lado el carácter pluricultural del Estado y el pluralismo jurídico, por otro eliminó las garantías de inalienabilidad, imprescriptibilidad e inembargabilidad que tenían las tierras indígenas desde las Constituciones de 1920 y 1930. En la práctica, esto posibilitó que un gran número de corporaciones transnacionales se instalaran en los territorios indígenas para realizar actividades extractivas, dando lugar a nuevas formas de despojo territorial bastante similares a las del siglo XIX (FAJARDO, 2011, p. 143).

O que se observa é o fortalecimento das relações de poder, que atendem mais ao interesse de grandes corporações internacionais do que ao interesse dos povos que vivem e tiveram direitos históricos reconhecidos constitucionalmente. Dessa forma, apresentou-se um quadro político em que alguns efeitos práticos decorrentes dessas novas garantias aos indígenas foram permeados com medidas que não inviabilizassem a pujança neoliberal. Como aponta Catherine Walsh, essa é uma estratégia política funcional dentro de um sistema-mundo moderno e ainda colonial, que "pretende "incluir" os anteriormente excluídos dentro de um modelo globalizado de sociedade regida não por pessoas, senão pelos interesses do mercado" (Tradução Livre) (2009b, p. 7).

\footnotetext{
112 "Sin duda, la ola de reformas educativas y constitucionales de los 90 -las que reconocen el carácter multiétnico y plurilingüístico de los países e introducen políticas específicas para los indígenas y afrodescendientes-, son parte de esta lógica multicultural de capitalismo transnacional." (WALSH, 2009b, p. 5).
} 
As consequências disso foram variadas e com alternativas paliativas, como, por exemplo, as reformas do Estado e do Sistema de Justiça fomentadas pelo Banco Mundial (BUHL, 1994). Nessas reformas foram incorporados mecanismos alternativos de resolução de conflitos prevendo, inclusive, a Justiça comunitária indígena (FAJARDO, 2011, p. 145). Na realidade esse sistema de justiça indígena possibilitava, tão só, a resolução de pequenos conflitos em âmbito comunitário. Por outro lado, as reformas serviram também às transnacionais ao flexibilizar a resolução de conflitos a partir da previsão da arbitragem internacional entre outros mecanismos eminentemente liberais.

Mesmo nesse contexto, as Constituições traziam elementos que pela primeira vez, na América Latina, enfrentavam o caráter monista proveniente do Estado. De uma forma geral, os povos tradicionais passam a exercer funções jurisdicionais específicas, empoderam autoridades próprias, estabelecem normas e procedimentos provenientes de práticas costumeiras, consideradas como o exercício de um pluralismo jurídico.

Diante da ofensiva neoliberal e do reconhecimento de direitos indígenas, em alguns países sucederam-se lutas políticas com caráter globalizante e, em grande medida, estimuladas por povos e comunidades tradicionais e outros componentes da classe trabalhadora. Conforme, já destacado nesse trabalho, a efervescência social estabelecida em países como a Bolívia, possibilitou a derrubada de alguns presidentes e a eleição presidencial de Evo Morales, em dezembro de 2005. A Constituição Boliviana de 2009 surge nesse contexto, rompendo com alguns fundamentos constitucionais anteriores.

A partir das lutas sociais e do "novo constitucionalismo" existente, alguns juristas dão um novo salto formulador e propõem o que consideram um "constitucionalismo sin padres ${ }^{113 ",}$ ou "constitucionalismo sem pais" fomentado por Assembleias eleitas e referendos de aprovação popular, crescente na

113 "Nadie, salvo el pueblo, puede sentirse progenitor de la constitución, por la genuina dinámica participativa y legitimadora que acompaña los procesos constituyentes." (MARTíNEZ DALMAU, 2008a, p. 19). 
América Latina, chamado por eles de "nuevo constitucionalismo latinoamericano" (MARTÍNEZ DALMAU, 2008b), ou conforme será utilizado, "novo constitucionalismo latino-americano". Essa perspectiva possui aspectos substanciais e densos do conteúdo jurídico normativo que traz a primazia constitucional, fortalece a busca incessante pela legitimidade democrática e dá ênfase aos anseios sociais, plurais e peculiares dos povos da América Latina. (MARTINEZ DALMAU; LEONEL JÚNIOR, 2014, p. 34). O fato de focar em aspectos próprios da realidade latino-americana permite que este novo fenômeno propicie reformulações estruturais do Estado e questionamentos da dinâmica constitucional historicamente reproduzida.

Essa é a proposta de um constitucionalismo que desestabilize as condições postas até então, justamente pela proposta real de adequar-se à uma realidade carecedora de justiça social, igualdade material, respeito a uma pluralidade de sujeitos excluídos historicamente do processo constitucional e da vida social. Assim, passam a ter a possibilidade de exercício de um protagonismo que antes partia de um sujeito constitucional abstrato, e agora, com o novo constitucionalismo latino-americano, o/a sujeito/a passa a transparecer sua cor, sua forma, sua identidade e seu potencial transformador.

De fato, inicia-se um processo diferenciado, novo, quanto às propostas constitucionais latino-americanas. A "máscara colonial" incorporada pelas Constituições dos países daqui começa a trincar. As novas Constituições latino-americanas propiciam um processo constitucional pensado com a "cabeça própria". O surgimento do "novo-constitucionalismo latino-americano" advém com a reorganização dos movimentos sociais progressistas no final do século XX e início do século XXI na América Latina contra as políticas neoliberais em curso. Exemplos não faltam, como a Constituição da República Bolivariana da Venezuela de 1999, a Constituição da República do Equador de 2008 e a Constituição do Estado Plurinacional da Bolívia de $2009^{114}$, a qual será trabalhada detalhadamente em momento posterior.

\footnotetext{
114 Para Rodrigo Uprymni estas novas Constituições estão vinculadas à chegada de novas forças políticas nesses respectivos países, conforme descreve; " (...) como en Venezuela, Ecuador o Bolivia, la nueva Constitución se encuentra vinculada al derrumbe del sistema de
} 
As Constituições, as quais partiam de elaborações pouco democráticas, decorrentes de elites históricas dominantes e subservientes aos países de economia central são escanteadas em grande medida. As organizações populares, a partir das mobilizações realizadas, encorpam-se e iniciam um processo de construção de hegemonia manifestada na Constituição e em suas novas características plurais e multifacetadas. Há quem considere nesse processo, inclusive, construções democráticas diferenciadas por conta do ambiente de efervescência política que está inserido e o caráter das reivindicações e postulações constitucionais. "[...] Uma democracia onde a igualdade material é o centro da atividade estatal, a igualdade formal é lançada ao baú da história hipócrita do constitucionalismo moderno" (Tradução Livre) (CHIVI VARGAS, 2010, p. 34). Há uma aposta na democracia participativa e representativa, na qual a participação popular será um grande indutor das mudanças. Destaca-se também o resgate de experiências e conhecimentos dos povos formadores da sociedade para a formulação teórica desde a interculturalidade, até mesmo a Plurinacionalidade. A estrutura políticoinstitucional passa a se reconfigurar conjugando o ser humano aos elementos relacionados à vida como um todo, seja ela humana ou não, considerando em certas situações elementos da Pachamama ${ }^{115}$ e prezando o "vivir bien" ${ }^{116 " . ~}$

O constitucionalismo estabelecido a partir de pequenos grupos que detinham o poder político e econômico, não conseguiu cumprir com a efetivação de aspectos realmente democráticos, tampouco constituir uma estrutura organizativa do Estado satisfatória com a realidade dos países. Apesar da forma constitucional configurar um elemento de continuidade, há uma ruptura genealógica. O novo constitucionalismo latino-americano

partidos anterior y al ascenso de nuevas fuerzas políticas, como el chavismo en Venezuela o el movimiento indígena en Bolivia o el correísmo en Ecuador" (2011, p. 109).

${ }^{115}$ Termo quéchua que trata da divindade relacionada à mãe-terra.

116 "Precisar el significado del Vivir Bien no es un tema o problema conceptual, en la medida en que la necesidad de su aclaración proviene de la necesidad de potenciar el horizonte histórico de los sectores que levan adelante en Bolivia, por lo que el trabajo de mayor definición del Vivir Bien es esencialmente práctico y de un carácter profundamente político" (ARKONADA, 2012, p. 8). 
apresenta perspectivas teóricas e práticas que rompem, em determinados aspectos, com o que até então era apresentado.

Cada una de las experiencias constituyentes mencionadas se conforma en sí misma como un modelo teórico-práctico propio de proceso constituyente. Pero todas ellas cuentan con un denominador común que, para el análisis realizado en esta sede, es necesario resaltar: asumen la necesidad de legitimar ampliamente un proceso constituyente revolucionario y, aunque los resultados son en buena medida desiguales, consiguen aprobar constituciones que apuntan, en definitiva, hacia el Estado constitucional. Teoría y práctica se unen, por lo tanto, en el nuevo constitucionalismo latinoamericano (MARTíNEZ DALMAU; VICIANO PASTOR, 2010a, p. 11-12).

O diagnóstico que Roberto Viciano Pastor e Rubén Martínez Dalmau fazem, tem um sentido prático ao verificar a participação social na dinâmica política desses países construtores desse novo constitucionalismo latinoamericano, um constitucionalismo subalterno e potencialmente transformador. Essa ampla participação social tende a entranhar-se na vida política do país e configurar uma quebra de paradigmas através do fortalecimento de um bloco político popular. "Todo sujeito ao transformar-se em ator, ainda mais quando é um movimento ou povo em ação, é o motor, a força, o poder que faz história" (DUSSEL, 2007, p. 116). Assim, a partir do panorama possibilitado pelo novo constitucionalismo latino-americano, outras alternativas político-jurídicas poderão emergir deste novo contexto na atualidade.

2.3.2 As características próprias do novo constitucionalismo latinoamericano e a Constituição do Estado Plurinacional da Bolívia 
Diante do contexto político, de surgimento do novo constitucionalismo latino-americano, é possível estabelecer características comuns aos processos constitucionais de determinados países, puxado por uma proposta de superação do constitucionalismo clássico em aspectos que esse não teria avançado. Principalmente, ao tratar das possibilidades de ressignificação do termo soberania popular, que ainda é usado como forma fundamental de legitimação das instituições e de gerência de um modelo de Estado liberal, não cumpridor das promessas da modernidade na América Latina. Novas relações e formas de poder são construídas nesse novo contexto.

Algo deve ser destacado na classificação dos autores espanhóis, que aqui nos referenciamos. É o estabelecimento de alguns elementos formais e materiais comuns a este novo constitucionalismo latino-americano.

Para fazer o debate mais específico a respeito da Constituição Boliviana promulgada em 2009, esses elementos trabalhados por Roberto Viciano Pastor e Rubén Martínez Dalmau serão utilizados e verificados. Contudo, o contexto do processo constituinte boliviano deve ser examinado para uma análise apurada dos elementos considerados na nova Constituição.

\subsubsection{O contexto do processo constituinte boliviano}

Cabe salientar que o quadro fundante para a promulgação da Constituição em $2009^{117}$, parte de uma luta política que ganha contornos

\footnotetext{
117 "La convocatoria de una Asamblea Constituyente que permitiera la transformación radical del Estado boliviano (refundación decían algunos) fue una consigna que comenzó a tener fuerza a partir del derrocamiento popular del Presidente Sánchez de Lozada. Esa propuesta, planteada originariamente por las organizaciones sociales, indígenas y campesinas fue convirtiéndose progresivamente en un reclamo nacional. Pero, sin embargo, quien sucediera en la Presidencia de la Republica a Sánchez de Lozada, su Vicepresidente Mesa, mantuvo una estrategia basada en no negar la posibilidad de convocar la Constituyente pero ir aplazando continuamente la misma, de tal manera que culminó su mandato sin que se hubiera
} 
concretos com a "guerra da água" de Cochabamba no ano 2000, a "guerra do gás" em outubro de 2003, seguidas quedas de presidentes e a eleição do líder sindical dos cocaleros, de origem Aymara, Evo Morales em $2005^{118}$.

Como se pode observar, o quadro político que possibilita essa realidade advém de uma progressiva efervescência dos movimentos sociais que se forjam como atores centrais frente ao sistema estabelecido e representam sujeitos capazes de gerar maior tensionamento do conflito social. Assim, a Assembleia Constituinte tomou um lugar fundante na luta política, possibilitando converter-se em um fator de aglutinação das diferentes forças e movimentos que pleiteavam mudanças.

Uma vez instalado o governo Evo, iniciou-se o processo constituinte boliviano, com a aprovação da Assembleia Constituinte, em Março de 2006, por meio de uma Lei Especial Convocatória n $3.364^{119}$.

A eleição dos constituintes ocorre na sequência, em 02 de Julho de 2006, com a vitória política do MAS-IPSP neste pleito. Destaca-se a eleição de Silvia Lazarte, militante social eleita pelo MAS-IPSP, como primeira presidenta mulher-indígena da Assembleia Constituinte.

conseguido el llamado a la misma. En ese periodo de tiempo de Presidencia interina, tan sólo se consiguió introducir un nuevo artículo en la Constitución Política del Estado por el que se preveía la posibilidad de convocar una Asamblea Constituyente para la reforma total del texto de la Constitución" (VICIANO PASTOR, 2008).

${ }^{118}$ ANEXO A - Ata de cômputo nacional das eleições gerais de 2005.

119 “(...) la Ley de Convocatoria de la AC estableció que los partidos políticos y las agrupaciones ciudadanas fueran las únicas instancias capaces de presentar diputados constituyentes. O sea, la Ley de Convocatoria condicionó la representación adentro de la $\mathrm{AC}$ a la afiliación partidaria o a la participación en organizaciones formales (...)" (MARTíNEZ; LINSALATA, 2011, p. 24-25). 


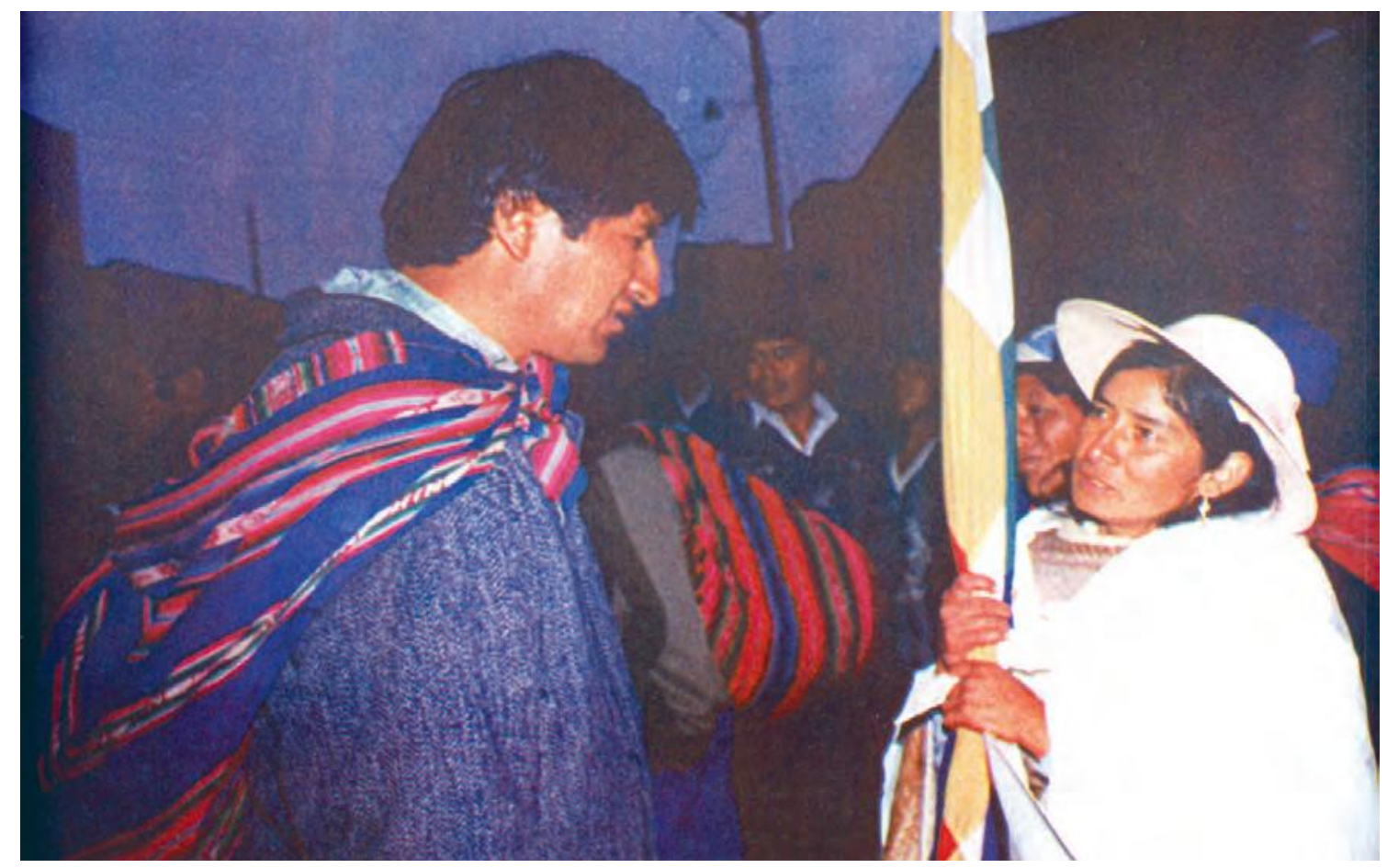

Foto 05 - Evo Morales, presidente indígena eleito na Bolívia e Sílvia Lazarte, eleita a primeira mulher-indígena presidenta da Assembleia Constituinte. Fonte: (HEMEROTECA, 2006)

Naquele contexto, o MAS-IPSP, partido do então presidente, possuía maioria parlamentar na Câmara Baixa e o PODEMOS - Poder Democrático y Social - principal partido da oposição aquele momento configurava-se como segunda força na Assembleia. 


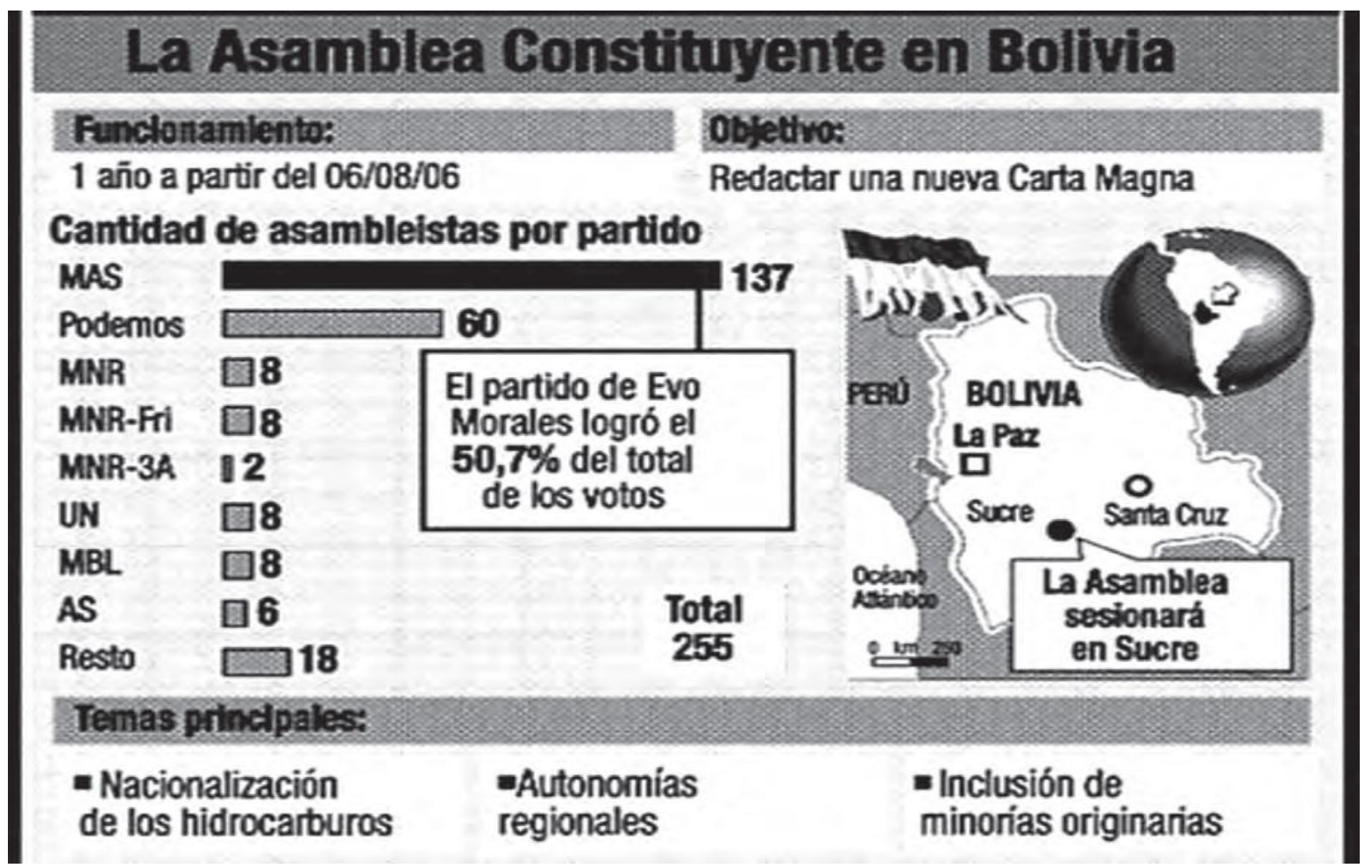

Tabela 02 - Quantidade de congressistas eleitos na constituinte por partidos.

Fonte: (CHE, 2006)

O MAS elegeu 137 dos 255 assembleistas (mais 5 que entraram com outras siglas partidárias); PODEMOS 60; a terceira força era 0 MNR (Movimento Nacionalista Revolucionário), com 18 constituintes através de três facções departamentais (MNR, MNR-FIR e MNR-A3); UN (Unidade Nacional) 8; o MBL (Movimento Bolívia Livre) 8; AS (Aliança Social) 6; CN (Consertação Nacional) 5; MOP (Movimento Originário do Povo) 3; APB (Autonomia Para Bolívia) 3; Ayra 2; ASP 2; o MIR-NM 1; MCSFA 1; e AAI 1. (SCHAVELZON, 2010, p. 120).

Diante das alianças, encabeçadas pelas duas principais forças políticas antagônicas, o grupo em torno do MAS-IPSP era responsável por 164 dos constituintes, 64\% das cadeiras, enquanto a oposição por 91 constituintes, 36\% das cadeiras. Contudo, no Senado a conjuntura não era tão favorável e os acordos com a oposição foram necessários por se exigir uma rígida maioria qualificada para a aprovação do instrumento legal (MARTíNEZ DALMAU, 2008b, p. 12). 
Toda esta dificuldade na aprovação de um projeto constitucional mais coeso politicamente foi orquestrada pela elite parlamentaria antes mesmo da eleição de Evo Morales.

Dicha decisión, imprescindible para abrir el paso a la Asamblea, fue aprobada por los partidos tradicionales de Bolivia en los últimos meses de su mandato parlamentario. Y no porque tuvieran el más mínimo interés en la convocatoria de la Asamblea sino porque como se empezaba a vislumbrar la posibilidad del triunfo electoral del Movimiento al Socialismo y su líder Evo Morales, se cubrieron la espalda estableciendo que la convocatoria de la Constituyente tendría que hacerse mediante una ley aprobada por dos tercios de los miembros del Congreso de la República. Con ello, obligaban a que los previsibles vencedores de la próxima contienda electoral necesitaran pactar con los partidos tradicionales (que previsiblemente iban a quedar en minoría en el nuevo parlamento) la convocatoria, elección y funcionamiento de la Asamblea Constituyente. Efectivamente, el apabullante triunfo del Movimiento al Socialismo y de Evo Morales, condujeron a la apertura del proceso constituyente. Pero como había sido previsto por los estrategas de la derecha boliviana, el Movimiento al Socialismo, a pesar de haber alcanzado un amplio triunfo electoral, no tenía los dos tercios de votos en el Congreso Nacional. Por ello, se vio abocado a negociar el contenido de la Ley de Convocatoria con quienes no creían en la Asamblea Constituyente y sólo estaban preocupados de intentar disminuir la capacidad transformadora de la misma. Realmente, el Movimiento al Socialismo se encontró con una difícil encrucijada (grifo nosso) (VICIANO PASTOR, 2008).

Assim, houve uma grande dificuldade para a aprovação de um texto constitucional tal qual propunha inicialmente a coalização puxada pelo MASIPSP e em convocar o referendo constitucional, em que deveria ser acordado por 2/3 dos constituintes presentes. Um considerável equívoco político verificado ao longo desse processo foi permitir que um poder constituído anterior, e ainda mais conservador, intervisse nas diretrizes de convocação da Assembleia, de maneira suficiente a comprometer em parte um processo de transformação ainda permeado pela institucionalidade e pelos mecanismos da democracia representativa. Dessa forma, alguns retrocessos foram inevitáveis 
na negociação política para a aprovação do referendo e do texto final constitucional. Mesmo reconhecendo os infindáveis avanços e inovações dessa nova Constituição caracterizada neste modelo do "novo constitucionalismo latino-americano".

Garcia Linera concebe esse período como o "ponto de bifurcação", já tratado no capítulo I. Os blocos antagônicos apresentam projetos políticos inconciliáveis na órbita da sociedade e do Estado, fazem um enfrentamento aberto, medem forças e entram em confronto como último recurso para dirimir as lutas, quando não há outra saída (2012a, p. 19). Os fatos hitóricos desse "ponto" encorpam-se com a tentativa do bloco da elite-burguesa derrotar Evo Morales através de um referendo revocatório de mandato popular ${ }^{120}$ em agosto 2008, não logrando êxito nesse pleito.

Mesmo com a eleição de Evo ao comando do poder central do Estado na Bolívia, os grupos da elite boliviana ainda possuíam muita força política, sobretudo, nos departamentos da "media luna", Pando, Beni, Santa Cruz e Tarija. Esses grupos optam por realizar ações de sabotagem, já que a democracia representativa era insuficiente para garantir-lhes o domínio político.

A falta de legitimidade e o antidemocratismo perante a opinião pública restaram claro, desmoralizando a ação do bloco burguês. Esse choque provocado por essa contradição antagônica entre os blocos fizeram os golpistas retrocederem por falta de força política para derrotarem o bloco indígena-popular. Certamente, esses conflitos tiveram incidência no resultado da constituinte.

As forças que compõem a situação chegam à Assembleia Constituinte com três projetos fortalecidos, de acordo com Sue lamamoto, relacionados às pautas indigenistas, nacionalistas e marxistas (2011, p. 110). A primeira vertente estará ligada aos setores indígenas do Altiplano e terras baixas demandando, sobretudo, a autonomia territorial indígena coexistente com o Estado boliviano. Já os setores nacionalistas, puxados por camponeses,

${ }^{120}$ ANEXO B - Gazeta oficial da Bolívia com a decretação do referendo amparado pela lei 3850 . 
operários e trabalhadores informais da cidade, defendem bandeiras mais próximas ao desenvolvimento das forças produtivas através da industrialização e nacionalização de recursos naturais para garantia das demandas populares. O setor ligado aos grupos marxistas transitaria por setores do operariado, indígenas e trabalhadores urbanos mais radicais, não admitindo acordos com a classe dominante e defendendo um projeto de coletividades autogovernadas dos variados setores sociais (IAMAMOTO, 2011, p.110-112). Esse último grupo apresenta características de um marxismo heterodoxo, porém mais sectário em sua compreensão tática. Certamente havia uma convergência central de pautas dentro desse bloco, por outro lado, essas características geraram o que analisaremos a partir da reflexão de Garcia Linera (2012a), como "tensões criativas" intrabloco.

Contudo, o grupo formador do pacto de unidade (CSUTCB, CONAMAQ, CIDOB, FNMCB-BS e CSCB), composto pelas organizações indígenas e camponesas, chega mais coeso e com reivindicações claras para o processo constituinte ${ }^{121}$ (PACTO DE UNIDAD, 2007). Assim, as diretrizes constitucionais são influenciadas fortemente por essa parcela do bloco indígena-popular ${ }^{122}$.

Os debates sobre plurinacionalidade, autonomias indígenas e política econômica são os mais estruturais para delineamento do novo Estado boliviano. (IAMAMOTO, 2011).

No primeiro caso, o Estado boliviano consistia em uma República com uma carga colonial e monocultural robusta em sua formação. $O$ reconhecimento de uma diversidade real de nações institucionaliza a presença indígena e fratura, em parte, as relações coloniais de dominação historicamente estabelecidas. A descentralização debatida através da plurinacionalidade implicava em uma estrutura estatal mais atenta ao funcionamento das estruturas comunitárias, à governança própria, às autoridades locais dentre outras ações inerentes à dinâmica das comunidades.

\footnotetext{
${ }^{121}$ ANEXO C - Documento assinado pelas organizações pelo Pacto de Unidade.

122 ANEXO D - Assembleia Nacional de Organizações Indígenas Originarias, Campesina y de Colonizadores da Bolívia. 05 de agosto de 2006.
} 
A descentralização não descaracteriza o Estado como unitário, contrapondo à proposta separatista da elite golpista boliviana.

No entanto, esse Estado Unitário precisa se fortalecer, uma vez que boa parte de suas divisas foram retiradas e seus setores estratégicos privatizados. Por esse debate partem as propostas da política econômica da Bolívia, sem perder de vista os aspectos ambientais, trazido pelas comunidades indígenas, e o vivir bien. Os embates intrabloco entre uma perspectiva indígena de manejo econômico e desenvolvimentista dão o tom dos debates, fruto, inclusive, da nacionalização dos hidrocarbonetos ${ }^{123}$.

De maneira geral, do ponto de vista econômico, as posições defendidas pelas agrupações que compõem a situação estão presentes dentro do próprio MAS-IPSP, com exceção da posição mais radical marxista de retirada do direito à propriedade privada da constituição. Por um lado, há uma proposta mais "indigenista" que defende que o Estado promova a economia comunitária indígena, incorporando tarefas de bem estar-estar específicas (como a garantia da soberania alimentar). Por outro lado, há uma proposta mais "nacionalista" que enxerga maior agência do Estado, que deve controlar a economia nacional e garantir políticas de bem-estar (vistas de maneira mais específica, como trabalho, saúde, educação, previdência, etc.). Tal proposta tem versões mais radicais (nacionalização completa e industrialização) e menos radicais (associação com capital internacional) (IAMAMOTO, 2011, p. 136).

Quanto às autonomias indígenas, as defesas dessa bandeira apareciam a partir de diversas visões dos variados grupos e suas formas de vivências. Entre os indígenas, já se observaria a diferenciação da dinâmica territorial dos que vivem nas terras altas do altiplano daqueles habitantes das

\footnotetext{
123 “(...) o governo do MAS-IPSP promulga o decreto de nacionalização dos hidrocarbonetos em maio de 2006, que exige que $82 \%$ da renda petroleira seja do Estado boliviano, e que 0 restante $18 \%$ fossem pagos às transnacionais como "pagamento de serviços". Tal divisão seria apenas temporária e o decreto visava um controle total do Estado da politica de hidrocarbonetos. Contudo, já em 2007, sob forte pressão das transnacionais e de seus respectivos governos (como a Petrobrás e o governo brasileiro), negocia-se uma divisão de $50 \%$ e $50 \%$, retornando à proposta do MAS-IPSP de se ter "sócios", que, portanto, devem operar com certa vantagem também." (IAMAMOTO, 2011, p. 135-136)
} 
terras baixas amazônicas, por exemplo. Logo, a forma de organização autonômica não era consensuada, nem mesmo pensada o quão ampliada seria essa autonomia. Isso porque "[...] o maior ponto de tensão é justamente com relação ao direito de consulta dos povos indígenas, que é reivindicado quando - Estado pretende fazer atividades nos territórios indígenas" (IAMAMOTO, 2011, p. 131), seja para a construção de estradas ou extração de recursos naturais. A maior parte das forças políticas ali presentes pactuou pelo direito à consulta prévia antes de alguma ação impactante do Estado (PACTO DE UNIDAD, 2007). Assim, o exercício autonômico sofre algumas limitações do poder central do Estado, aproximando do entendimento previsto na Convenção 169 da OIT - Organização Internacional do Trabalho.

Alguns conflitos foram marcantes nesse processo constituinte, mesmo que parte deles tenha ocorrido anteriormente ao clímax do "ponto de bifurcação". Um deles foi a partir da intenção da oposição, de que a capital constitucional fosse exercida plenamente na cidade de Sucre. O que não ocorreu, pois a sede do Governo - Poder Executivo - e o Legislativo ficaram em La Paz. Esta foi uma tática utilizada para travar o andamento do processo constituinte por alguns meses.

As vinte uma comissões de trabalho estabelecidas ${ }^{124}$, começaram a construir o texto constitucional em 17 de janeiro de 2007. Assim, os/as constituintes andaram por toda Bolívia, acompanhados de assessores/as, para receberem propostas de distintas organizações e da sociedade civil.

\footnotetext{
124 As Comissões eram as seguintes: 1) Visão de país; 2) Cidadania, nacionalidade e nacionalidades; 3) Deveres, Direitos e garantias; 4) Organização e estrutura do novo Estado; 5) Legislativo; 6) Judicial; 7) Executivo; 8) Outros órgãos do Estado; 9) Autonomias departamentais, provinciais, municipais e indígenas, descentralização e organização territorial; 10) Educação e Interculturalidade; 11) Desenvolvimento social integral; 12) Hidrocarbonetos; 13) Mineração e metalurgia; 14) Recursos hídricos e energia; 15) Desenvolvimento produtivo rural, agropecuário e agroindustrial; 16)Recursos naturais renováveis, terra, território e meio ambiente; 17) Desenvolvimento integral amazônico; 18) Coca; 19) Desenvolvimento econômico e finanças; 20) Fronteiras nacionais, relações internacionais e integração; 21) Segurança e defesa nacional.
} 
Cronograma de los Encuentros Tenritoriales aprobado por Plenaria

\begin{tabular}{|l|l|}
\hline Lugar & Fechas \\
\hline Cobija & 12 y 13 de marzo \\
\hline La Paz & 16 y 17 de marzo \\
\hline Sucre & 20 y 21 de marzo \\
\hline Potosí & 23 y 24 de marzo \\
\hline Oruro & 26 y 27 de marzo \\
\hline Cochabamba & 29 y 30 de marzo \\
\hline Santa Cruz & 2 y 3 de abril \\
\hline Tarija & 1 y 11 de abril \\
\hline Trinidad & 13 y 14 de abril \\
\hline
\end{tabular}

Tabela 03 - Cronograma de debates sobre o programa constitucional nos Departamentos. Fonte: (HEMEROTECA, 2007)

Somente em Santa Cruz, os trabalhos das Comissões foram prejudicados, em parte, justamente pela agressão da organização chamada "união da juventude crucenha" a um constituinte do MAS. Em Julho de 2007 realizou-se a entrega oficial dos informes finais das vinte e uma comissões, mesmo restando algumas poucas questões pendentes. No dia 24 de novembro de 2007 aprovou-se a primeira proposta de texto constitucional.

Outro episódio conturbado aconteceu, motivado pela transferência da sede da Constituinte, da cidade de Sucre para a cidade de Oruro, devido ao cenário adverso e conflituoso que existia na capital. A polícia nacional tinha dificuldades em garantir a segurança dos assembleístas no teatro Mariscal, onde eram realizados os trabalhos ${ }^{125}$. Em Oruro, mais de 400 artigos foram aprovados em uma sessão que durou dezeseis horas contínuas, nos dias 08 e 09 de dezembro de 2007, deliberando-se a nova proposta. Alguns dias depois desse episódio, o texto foi entregue ao Presidente.

\footnotetext{
${ }^{125}$ ANEXO E - Despacho do comando da Polícia nacional à Presidenta da Assembleia constituinte.
} 


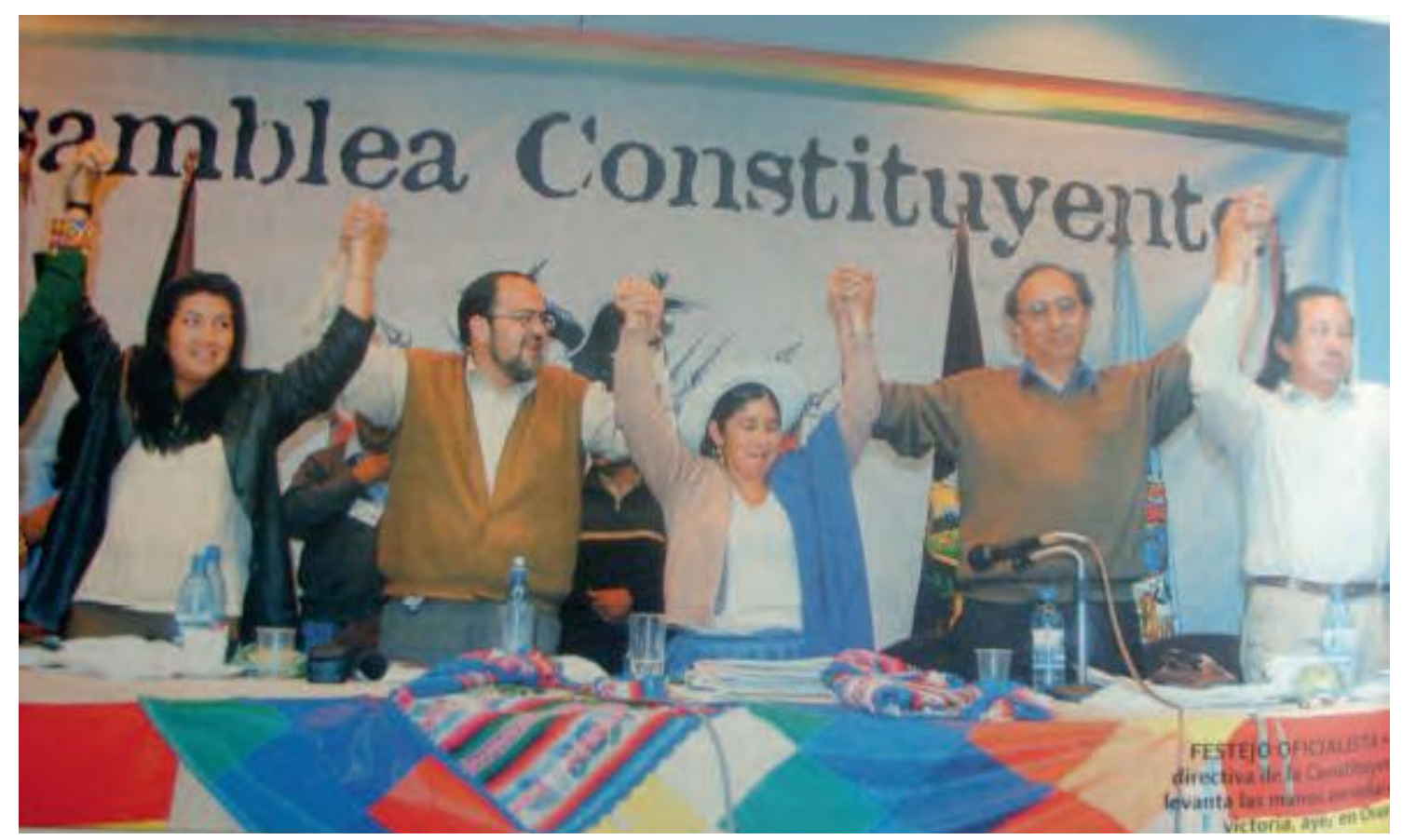

Foto 06 - Oruro, 09 de dezembro de 2007, dois terços dos congressistas presentes aprovaram os 411 artigos da Nova Constituição Política do Estado. Artigos que ainda seriam alterados posteriormente.

Fonte: (HEMEROTECA, 2007b)

A oposição acusou a situação de desrespeito aos procedimentos estabelecidos (ROJAS, 2009) e grande parte dos constituintes da oposição não participou da sessão em Oruro.

Após esse episódio, os conflitos intensificaram-se, ao longo de 2008, e o MAS-IPSP teve que negociar com a oposição, o que havia sido aprovado em Oruro. Para o estabelecimento de um acordo, uma reunião foi realizada em Cochabamba em outubro de 2008, em que diversos artigos foram alterados, modificando parte do conteúdo e da forma do que já estava aprovado. A versão do texto constitucional, formulada em Oruro, era muito mais avançada na garantia de direitos e nas mudanças estruturais ${ }^{126}$. Boaventura de Sousa Santos destaca as perdas decorrentes dessa negociação. Cabe salientar, que sem a negociação em si, dificilmente sairía a aprovação do referendo constitucional;

\footnotetext{
${ }^{126}$ As alterações constitucionais mais consubstanciais giravam em torno do debate autonômico, e política dos hidrocarbonetos. Cf. ANEXO F - Acordo final da mesa de diálogo nacional estabelecida.
} 
Finalmente, el Congreso se transforma, sobre las ruinas de la Asamblea Constituyente, en Congreso Constituyente y prepara la versión definitiva de la Constitución que será refrendada en referéndum nacional en enero de 2009. El Congreso cambia 144 artículos y, según Raúl Prada, todas las modificaciones son de carácter conservador. Las pérdidas se producen sobre todo para el movimiento popular, indígena, originario y campesino. (..) no se define el número de circunscripciones especiales indígenas en la Asamblea Legislativa Plurinacional, reduciéndose luego a solamente siete en la Ley Electoral Transitoria; se impide la reforma agraria al determinar la noretroactividad de la ley sobre el tamaño máximo de la propiedad de la tierra; se restringe la justicia comunitaria indígena, confinándola a indígenas en sus territorios y entre sí; se altera la composición del Tribunal Constitucional Plurinacional que pasa a exigir como requisito para todos sus miembros la formación jurídica académica eurocéntrica, y apenas algunos de ellos deben tener conocimiento de los derechos indígenas (2010, p. 80-81).

Por outro lado, rechaçava-se de vez o intento separatista e golpista do bloco burguês. Esse "acordo" ocorrido em Cochabamba, agregando pautas da oposição, pode ser visto como elemento deslegitimador do texto já aprovado pela Assembleia Constituinte, porém somente depois dele é viabilizada a aprovação da Lei especial convocatória do referendo que aprovaria a nova Constituição, a qual ocorrera em Janeiro de 2009.

A Constituição, do que passa a ser renomeado como o Estado Plurinacional da Bolívia, foi referendada com a participação de mais de $90 \%$ dos eleitores bolivianos, onde mais de $61,43 \%$ aprovaram o conteúdo da Carta Magna em 25 de Janeiro de 2009. Além da aprovação do conteúdo constitucional, na mesma cédula do referendo aprovou-se a limitação do tamanho máximo da propriedade na Bolívia a 05 mil hectares para inviabilizar a reprodução de latifúndios ${ }^{127}$. A partir de então, tratava-se de um Estado Unitário, porém plurinacional.

\footnotetext{
${ }^{127}$ ANEXO G - Cédula do referendo que limitou a propriedade à 5 mil hectares no máximo e aprovou a Constituição.
} 


\begin{tabular}{|c|c|c|c|}
\hline \multicolumn{4}{|c|}{$\begin{array}{r}\text { Referendum maclomal constr } \\
\text { Resultados }\end{array}$} \\
\hline & Rospubatise & Motiog & 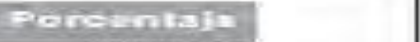 \\
\hline & Si & 2.064 .417 & $61.43 \%$ \\
\hline & No & 1.296 .175 & $38,57 \%$ \\
\hline & Wonose & Fotalde & Parcieristale \\
\hline & Vafidos: & 3.360 .592 & $95,70 \%$ \\
\hline & Elancos & 59.524 & $1.70 \%$ \\
\hline & Nutos & 91.583 & $2.61 \%$ \\
\hline & Emitidos & 3.511 .699 & $100,00 \%$ \\
\hline & Desaripelon & Tarater & Parconiteris \\
\hline & $\begin{array}{l}\text { Mesas } \\
\text { Habiltiadass }\end{array}$ & 22,049 & $100,00 \%$ \\
\hline & $\begin{array}{l}\text { Mesas } \\
\text { Reportadas }\end{array}$ & 22,024 & $99,89 \%$ \\
\hline & $\begin{array}{l}\text { Masas } \\
\text { Fusionadas }\end{array}$ & 25 & $0.11 \%$ \\
\hline & $\begin{array}{l}\text { Nesas oue } \\
\text { No } \\
\text { Funcionaron }\end{array}$ & a & $0,00 \%$ \\
\hline & $\begin{array}{l}\text { Actas } \\
\text { Observadas. }\end{array}$ & a & $0,00 \%$ \\
\hline & $\begin{array}{l}\text { Mesas No } \\
\text { Reportadas }\end{array}$ & a & $0,00 \%$ \\
\hline & Deseriperan & Contrabal & Porcantale \\
\hline & $\begin{array}{l}\text { Imscritos } \\
\text { Habilivados }\end{array}$ & 3.891 .316 & \\
\hline & $\begin{array}{l}\text { Votos } \\
\text { Computados }\end{array}$ & 3.511 .699 & \\
\hline & $\begin{array}{l}\text { Participación } \\
\text { computada }\end{array}$ & & $90,2 \theta \Psi a$ \\
\hline CLOS & $\begin{array}{l}\text { porcentajes de } \\
\text { función al total }\end{array}$ & $\begin{array}{l}\text { votación, } \\
\text { de vatos }\end{array}$ & $\begin{array}{l}\text { som calcutados en } \\
\text { computados? }\end{array}$ \\
\hline
\end{tabular}

Tabela 04 - Resultado do Referendo Constituinte de 2009.

Fonte: (BOLIVIA, 2009)

Ao dia 07 de Fevereiro de 2009, o presidente Evo Morales, em um ato perante a população, proclama a Constituição pautando sua importância para o contexto histórico e político da América Latina. 


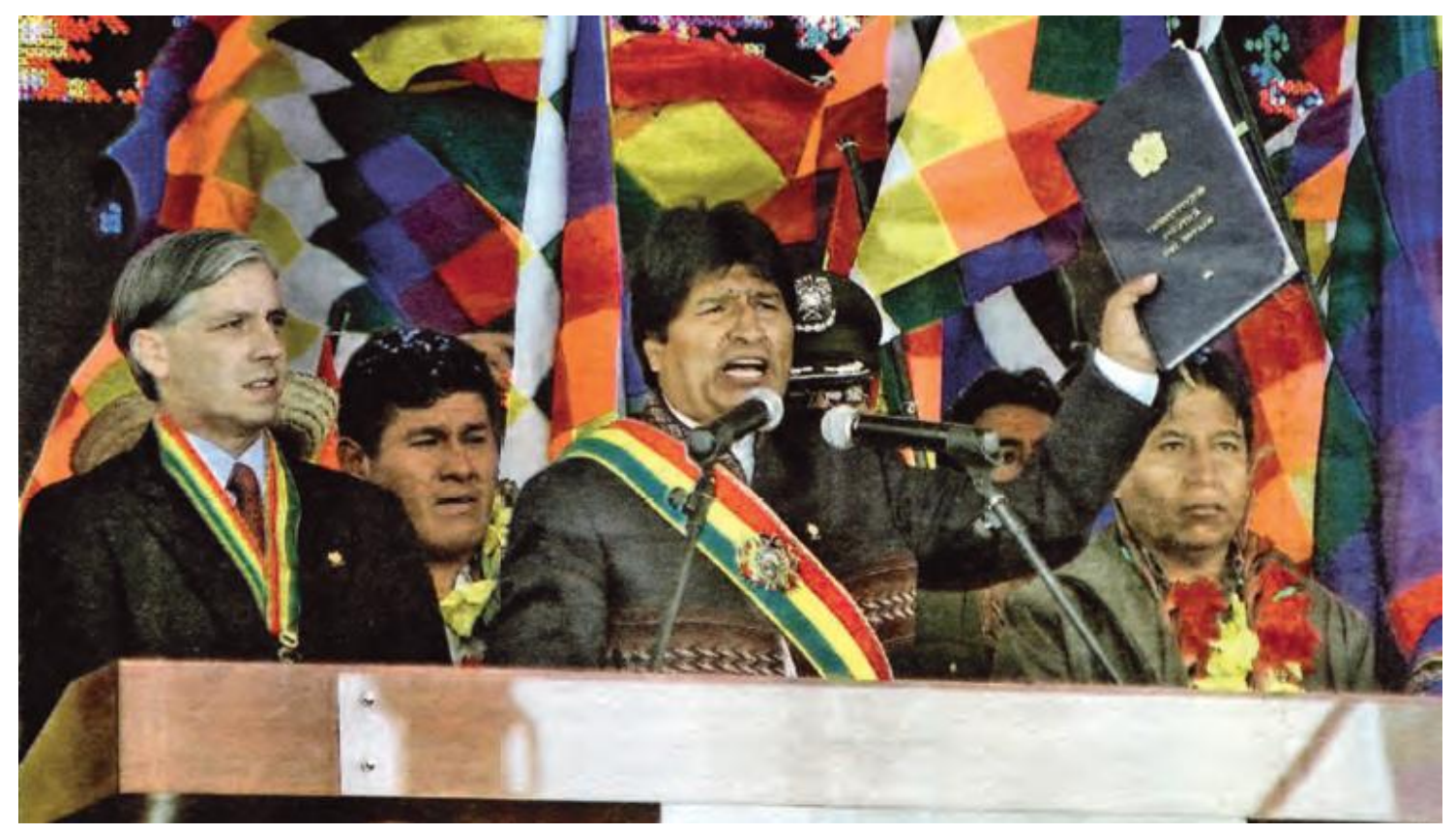

Foto 07 - 0 presidente mostra a nova Carta Magna aos cidadãos depois de promulgá-la. Fonte: (HEMEROTECA, 2009)

Hermanos y hermanas, bolivianos y bolivianas: después de 500 años de rebelión, invasión y el saqueo permanente; después de 180 años de resistencia contra un Estado colonial, después de 20 años de lucha permanente contra un modelo neoliberal, hoy 7 de febrero de 2009, es un acontecimiento histórico, un acontecimiento inédito, singular para Bolivia y para Latinoamérica, reunido acá para promulgar la nueva Constitución Política del Estado (MORALES, 2009, p. VII).

2.3.2.2 Os aspectos formais característicos da nova Constituição Política do Estado Boliviano

Diante deste quadro histórico, será realizada uma análise da Constituição, com maior cautela e foco político. Conforme situam Roberto Viciano Pastor e Rubén Martínez Dalmau, podem ser caracterizados elementos 
comuns formais e materiais em Constituições recentes na América Latina. Trato de verificá-los direcionando o olhar para a Constituição boliviana.

\begin{abstract}
A todo ello cabe añadir que han sido cuatro las características formales que más han caracterizado al nuevo constitucionalismo: su contenido innovador (originalidad), la ya relevante extensión del articulado (amplitud), la capacidad de conjugar elementos técnicamente complejos con un lenguaje asequible (complejidad), y el hecho de que se apuesta por la activación del poder constituyente del pueblo ante cualquier cambio constitucional (rigidez) (MARTÍNEZ DALMAU; VICIANO PASTOR, 2010a, p. 14).
\end{abstract}

Assim, os autores espanhóis trazem a originalidade, a amplitude das normas, a complexidade aliada a uma linguagem simples e a rigidez como elementos formais comuns às Constituições caracterizadas nesse contexto do "novo constitucionalismo latino-americano". Diante dessas características, vejamos onde elas se expressam na Constituição Boliviana.

A Constituição do Estado Plurinacional da Bolívia dá um giro inovador na forma que se apresenta. Mesmo no momento em que há uma reprodução de institutos com um procedimento constitucional padrão, a partir dos poderes estabelecidos, observar-se-á uma fratura com o sistema anterior ao averiguarem-se alguns elementos constitucionais inseridos, como produto da luta social boliviana. Pois, conforme pontuado, não há uma ruptura completa, uma vez que estão presentes inúmeros componentes resultantes de uma vitória não integral do bloco indígena-popular, remediada por um acordo político com o bloco antagônico para a aprovação do referendo e do texto final constitucional.

Ao verificar-se o preâmbulo constitucional, transmite-se imediatamente uma mensagem de não aceitação de um contínuo desenvolvimento político subserviente e colonial. A opção pelo giro descolonizador apresentada é urgente e original, conforme destacada no trecho abaixo. 
"Dejamos en el pasado el Estado colonial, republicano y neoliberal. Asumimos el reto histórico de construir colectivamente el Estado Unitario Social de Derecho Plurinacional Comunitario, que integra y articula los propósitos de avanzar hacia una Bolivia democrática, productiva, portadora e inspiradora de la paz, comprometida con el desarrollo integral y con la libre determinación de los pueblos."

Isto é uma mera demonstração de que a Bolívia inicia um caminho no sentido de descolonizar o poder, ou seja, deixar a histórica reprodução acrítica de paradigmas liberais estadunidenses/europeus e considerar a subjetividade de seus povos para pensar a melhor forma de exercício de poder. Assim, nega o conceito de República ${ }^{128}$, para além do que significa na ciência política, que ao pé da letra, constitui-se como "coisa do povo", mas que no imaginário coletivo do povo boliviano remete a um Estado centralista, monocultural, homogeneizador e liberal. O significado político que emerge por esta utilização simbólica da linguagem é fundamental para uma apropriação popular deste sentimento e potencial ação transformadora. A dimensão normativa do direito sedimenta o discurso político vitorioso e popular no preâmbulo para orientar a interpretação sistemática do corpo constitucional.

O peruano Aníbal Quijano destaca a importância em desenvolver estas potencialidades, decorrentes de momentos insurrecionais, que estavam adormecidas e iniciam um período de despertar desse sono indolente frente às ações dominadoras das grandes potências.

Ha comenzado así un proceso de des/colonialidad de la existencia social. Un nuevo horizonte histórico está emergiendo. Eso implica, en primer término, nuestra emancipación del Eurocentrismo, esa forma de producir subjetividad (imaginario social, memoria histórica y conocimiento) de modo distorsionado y distorsionante, que, aparte de la violencia, es el más eficaz instrumento de control que el capitalismo colonial/moderno tiene para mantener la

\footnotetext{
${ }^{128}$ Apesar da palavra "República" não estar contida na denominação do Estado, ainda sim aparece em inúmeros dispositivos ao longo da Constituição, como pode ser verificado. Vide artigos 11, 146, 202, 238 e 339. Ou seja, se reconhece elementos republicanos na Constituição, mesmo abdicando da sua denominação no preâmbulo.
} 
existencia social de la especie humana dentro de este patrón de poder. Esa emancipación es, precisamente, lo que esta ocurriendo; eso es lo que significa descubrir que los recursos de sobrevivencia de los indígenas del mundo son los mismos recursos de la vida en el planeta, y descubrir al mismo tiempo, en el mismo movimiento de nuestras luchas, que ya tenemos la tecnología social para prescindir del capitalismo (QUIJANO, 2009, p. 03).

Da mesma forma que em outras partes da América Latina, a Bolívia sofreu todas as consequências sacrificiais e violentas no início do desenvolvimento capitalista, em seu estágio mercantil, e agora possibilita a criação de alternativas a este padrão, as quais serão analisadas em um momento posterior ${ }^{129}$. Mesmo que estas alternativas ainda não estejam bem direcionadas, o fato de rechaçar o passado colonial esquivando-se do temor de um cenário neocolonialista, já é um sinal de mudança.

Quanto aos elementos formais comuns neste "novo constitucionalismo latino-americano", a originalidade é verificável diante das propostas de construção de uma nova sociedade perante novas instituições e mesmo uma nova forma e padrão de concepção da política. Boaventura de Sousa Santos chega a tratar essas mudanças como um constitucionalismo experimental e transformador, o qual aponta para caminhos anticapitalistas e anticolonialistas (2010, p. 77). Os problemas que ocorrem na América Latina são melhor diagnosticados e tratados com soluções próprias e não, meramente, reproduzidas de um outro centro e interesse político. Algo que era comum, ao incorporarmos sem questionar, modelos constitucionais estruturados de acordo com determinadas regiões geopolíticas e intencionalidades, que não as populares e latino-americanas.

Conforme já explicitado, a Constituição Boliviana age com literal originalidade ao aderir à denominação de Estado Plurinacional da Bolívia ${ }^{130}$,

\footnotetext{
${ }^{129}$ Ver Capítulo 3.

${ }^{130}$ Assim denominado a partir da promulgação da Constituição em 2009, devendo ser utilizada em todos os atos públicos e privados nas relações diplomáticas internacionais, assim como a correspondência oficial a nível nacional e internacional, a denominação Estado Plurinacional de
} 
ressaltando a pluralidade em seu próprio nome. O pluralismo passa a principal inovação advinda com a Constituição, pois ela está presente e é considerada em todos os aspectos da dinâmica social boliviana, tal como prevê o artigo primeiro.

Artículo 1. Bolivia se constituye en un Estado Unitario Social de Derecho Plurinacional Comunitario, libre, independiente, soberano, democrático, intercultural, descentralizado y con autonomías. Bolivia se funda en la pluralidad y el pluralismo político, económico, jurídico, cultural y lingüístico, dentro del proceso integrador del país. (grifo nosso).

O pluralismo destaca-se como atributo central da Constituição boliviana. Choca-se diretamente com a figura do monismo e, assim, apresenta um propósito diverso dos modelos constitucionais, até então, implementados. A originalidade destaca-se em várias passagens do texto constitucional ${ }^{131} \mathrm{e}$ permite que as consequências concretas desses comandos sejam profundamente transformadoras. Pois, indica um momento constitucional que transita de um Estado republicano, neoliberal, opressor, que nega as subjetividades e manifestações de um povo, para um Estado que almeja reconhecer a pluralidade da reprodução social popular e compor a unidade estatal sem omitir a diversidade cultural.

Esta caracterização plural, ao tratar da diversidade étnica, afirma a alteridade dos povos latino-americanos. A própria análise do contexto político do processo constitucional demonstra isso. Não é mera retórica de igualdade constitucionalista entre os diferentes, distinguindo-se de outros processos históricos em que o pluralismo foi considerado a partir de um enfoque multicultural, ou seja, dentro da ordem estabelecida. A pluralidade resultante da

Bolivia, a partir de 18 de março de 2009 (segundo Decreto supremo ํㅡ 48, de 18 de março de 2009) (ONU, 2010).

131 O reconhecimento da diversidade no âmbito de um Estado Plurinacional boliviano permite que conceitos provenientes da tradição indígena andina sejam constitucionalizados, como o do vivir bien. Cf. Artigo 306 da Constituição Boliviana. 
demanda das lutas e setores populares interfere no processo de construção social e em alternativas para além das receitas imperialistas, de cunho liberal, na construção do entendimento constitucional.

(...) frente al reconocimiento de la diversidad étnica es posible encontrar al menos tres tipos distintos de constitucionalismos: algunos ordenamientos, como el chileno, el uruguayo y el costarricense, tienden a mantenerse en el pluralismo liberal en tanto no reconocen derechos especiales de grupo a las comunidades étnicas; otros, como el colombiano, en especial gracias a la jurisprudencia de su Corte Constitucional, tienden a plantearse como una forma de constitucionalismo multiétnico y multicultural; finalmente, las recientes Constituciones ecuatoriana y boliviana van más lejos porque establecen un Estado plurinacional e intercultural (UPRYMNI, 2011, p. 127).

Outro elemento formal comum destacado é a amplitude das Constituições. No caso da Constituição boliviana de 2009 são 411 artigos. Ela é considerada um dos textos constitucionais mais extensos do mundo. A Constituição boliviana está dividida em cinco partes, dez disposições transitórias, uma disposição ab-rogatória e uma disposição final. A diferença é visível ao comparar com a Constituição anterior de 1967, que continham 234 artigos divididos em quatro partes.

Una constitución tiene por objetivo producir la unidad política de un territorio y un conjunto de poblaciones. En este sentido, como la tarea es la producción de la unidad política, una constitución por lo tanto tiene que contener un conjunto de instituciones que sean formas de integración o de inclusión. La principal forma a través de la cual una constitución realiza y reconoce estas formas de inclusión e integración es a través del reconocimiento de derechos y el tipo de ciudadanía que define. En este sentido, una constitución es una forma de definición de los procesos de inclusión e integración política a través de un conjunto de derechos. Una constitución es una estructura de derechos. Es por eso que el cuerpo más extenso de las constituciones consiste, precisamente, en los diferentes regímenes de derechos a través de los cuales se instituye la integración e inclusión política de las personas como parte de la unidad política y el país (TAPIA, 2007a, p. 108). 
Antônio Carlos Wolkmer e Lucas Machado destacam, ao tratarem da amplitude da Constituição, a grande quantidade de "[...] artigos extensos para demarcar o profundo alcance jurídico e mesmo político que a positivação constitucional proporciona" (2011, p. 386). Há uma clara intenção em descrever pormenorizadamente a previsão de direitos, para não restar dúvidas quanto à existência destes. A utilidade da previsão exaustiva de direitos também facilita o reconhecimento dos mesmos e a materialização por juízes e tribunais, ainda que conservadores.

De toda forma, não basta dogmaticamente prever rol de direitos. Afirmá-los formalmente é reproduzir a mera bandeira liberal. Há uma necessidade de se introduzir mudanças profundas na estrutura constitucional para permitir a viabilidade e execução desse rol de direitos.

Este caráter relacionado à amplitude presente no novo constitucionalismo latino-americano propicia o surgimento de outra característica própria deste modelo constitucional, a complexidade.

Esta característica evidencia-se, sobretudo, na tentativa de abarcar uma gama muito ampla de situações diversas, objetivando uma maior acessibilidade dos povos aos direitos previstos. O artigo 5ㄴ, inciso I, é um exemplo disso ao garantir como idiomas oficiais do Estado, o castelhano e todos os outros de nações e povos indígenas, descrevendo quase quarenta etnias $^{132}$. Da mesma forma, junto à bandeira, verde, amarela e vermelha, o símbolo da whipala ${ }^{133}$ é considerado bandeira oficial do Estado Boliviano. Assim, resta demonstrada a tentativa de agregar o que já estava oficialmente

\footnotetext{
132 "Artículo 5. I - Son idiomas oficiales del Estado el castellano y todos los idiomas de las naciones y pueblos indígena originario campesinos, que son el aymara, araona, baure, bésiro, canichana, cavineño, cayubaba, chácobo, chimán, ese ejja, guaraní, guarasu'we, guarayu, itonama, leco, machajuyai-kallawaya, machineri, maropa, mojeño-trinitario, mojeño-ignaciano, moré, mosetén, movima, pacawara, puquina, quechua, sirionó, tacana, tapiete, toromona, uruchipaya, weenhayek, yaminawa, yuki, yuracaré y zamuco.

${ }^{133}$ É uma bandeira quadrangular de sete cores que representam a filosofia e o meio de vida de algumas etnias andinas, sobretudo, a aymara. Cada uma das cores traz algum significado e representa os raios solares que se decompõem em um arco-íris transmitindo a mensagem de uma sociedade harmônica e comunitária nos Andes.
} 
constituído com elementos outros, de singular importância para o povo boliviano $^{134}$.

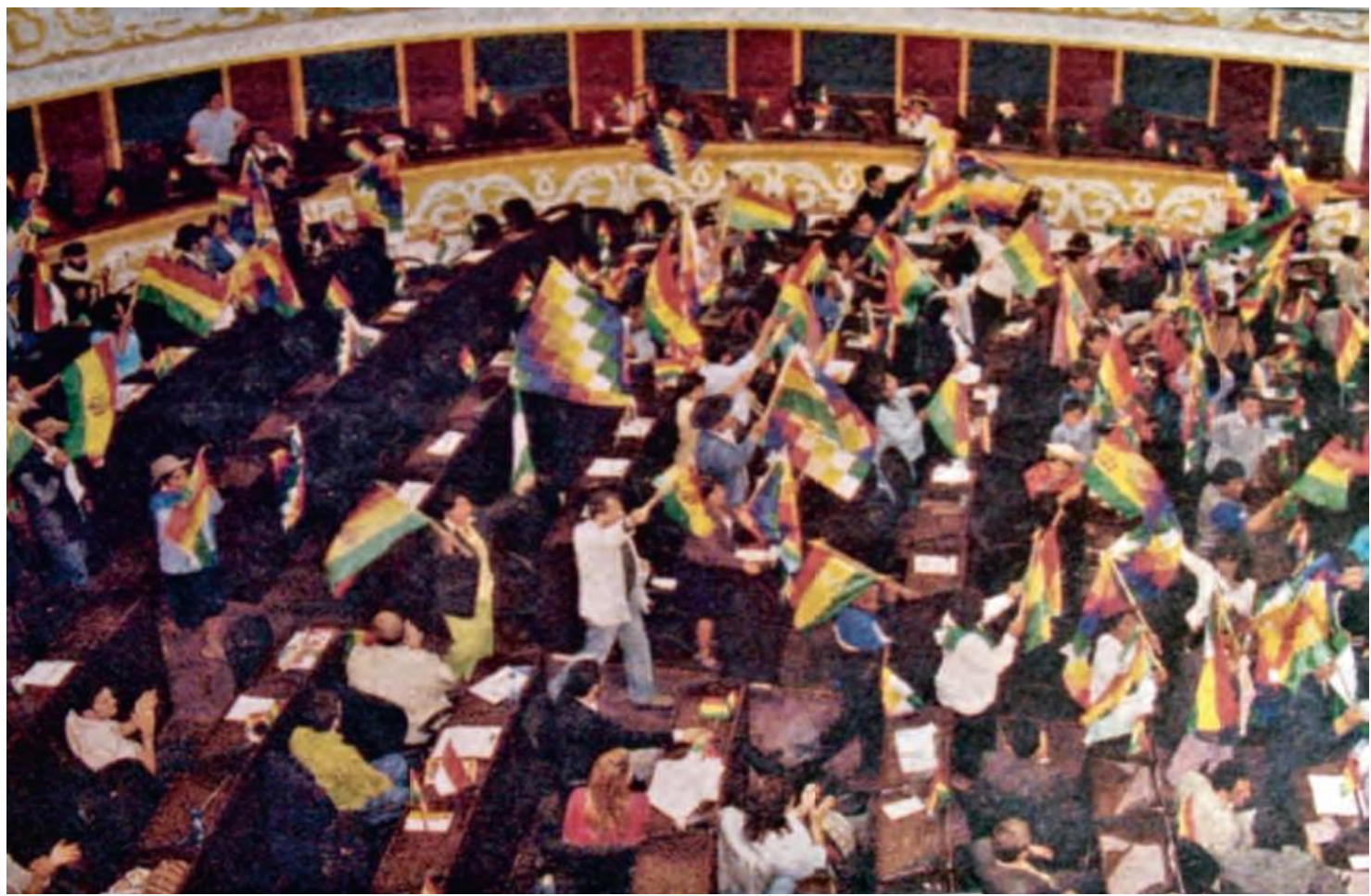

Foto 08 - 0 Ingresso dos constituintes do MAS com a bandeira tradicional e a wiphala para exporem sua visão de país na sessão plenária de 7 de março de 2007.

Fonte: (HEMEROTECA, 2007c)

A concisão e a forma prolixa, diferenciando-se do padrão das Constituições liberais, não configuram uma realidade neste novo modelo constitucional. "Esta complexidade técnica vem acompanhada de uma simplicidade linguística devida à vontade de transcender o constitucionalismo das elites para um constitucionalismo popular" (Tradução Livre) (MARTíNEZ DALMAU; VICIANO PASTOR, 2010a, p. 17).

Este caráter popular que a linguagem possibilita ajuda na compreensão dos termos e no exercício de direitos. Isso resta claro, desde a utilização de expressões em outros idiomas, além do castelhano, como o aymara, quéchua

\footnotetext{
134"Artículo 6.

( ...)

II- Los símbolos del Estado son la bandera tricolor rojo, amarillo y verde; el himno boliviano; el escudo de armas; la wiphala; la escarapela; la flor de la kantuta y la flor del patujú".
} 
ou guarani, tal qual previsto nos termos, "ama qhilla, ama llulla, ama suwa, suma qamaña, ñandereko, teko kavi, ivi maraei y qhapaj ñan"135. Isso demonstra uma apreensão constitucional com princípios éticos-morais daquela pluralidade social boliviana, que estabelece diretrizes para a busca do vivir bien. Da mesma forma, essa nova linguagem constitucional desconstitui a corrente utilização do latim para referir-se a determinados termos jurídicos. $O$ habeas corpus e o habeas data passam a ser denominados com o seu simples significado, "ação de liberdade" e "ação de proteção à privacidade", agora destituídos da pompa jurídica elitista (MARTíNEZ DALMAU; VICIANO PASTOR, 2010a, p. 17).

Cabe ainda destacar dentre as características formais comuns, a verificação da rigidez constitucional; ou seja, uma maior dificuldade para a ocorrência de modificações na Constituição. Essa é uma forma de garantir que os fundamentos previstos nessas novas Constituições latino-americanas, inclusive na boliviana, permaneçam e permitam a configuração de um projeto político diferenciado e inovador. A Constituição boliviana, por exemplo, admite a reforma constitucional, ainda que parcial, somente com um referendo constitucional aprovando o feito (MARTINEZ DALMAU; LEONEL JÚNIOR, 2014, p. 30).

Art. 411. I. La reforma total de la Constitución, o aquella que afecte a sus bases fundamentales, a los derechos, deberes y garantías, o a la primacía y reforma de la Constitución, tendrá lugar a través de una Asamblea Constituyente originaria plenipotenciaria, activada por voluntad popular mediante referendo. La convocatoria del referendo se realizará por iniciativa ciudadana, con la firma de al menos el veinte por ciento del electorado; por mayoría absoluta de los miembros de la Asamblea Legislativa Plurinacional; o por la Presidenta o el Presidente del Estado. La Asamblea Constituyente se autorregulará a todos los efectos, debiendo aprobar el texto

135 "Artículo 8.

1. El Estado asume y promueve como principios ético-morales de la sociedad plural: ama qhilla, ama llulla, ama suwa (no seas flojo, no seas mentiroso ni seas ladrón), suma qamaña (vivir bien), ñandereko (vida armoniosa), teko kavi (vida buena), ivi maraei (tierra sin mal) y qhapaj ñan (camino o vida noble)". 
constitucional por dos tercios del total de sus miembros presentes. La vigencia de la reforma necesitará referendo constitucional aprobatorio.

II. La reforma parcial de la Constitución podrá iniciarse por iniciativa popular, con la firma de al menos el veinte por ciento del electorado; o por la Asamblea Legislativa Plurinacional, mediante ley de reforma constitucional aprobada por dos tercios del total de los miembros presentes de la Asamblea Legislativa Plurinacional. Cualquier reforma parcial necesitará referendo constitucional aprobatorio.

Essas experiências constitucionais ainda são observadas em suas ações teóricas e práticas, onde se configura um período de transição de modelos constitucionais, deixando muitos temas ainda abertos. Contudo, a própria Constituição boliviana aponta caminhos não trilhados anteriormente, os quais questionam paradigmas constitucionais históricos e abrem perspectivas distintas para o povo.

2.3.2.3 Os elementos estruturantes da nova Constituição Política do Estado boliviano

A materialidade constitucional é fundamental para a concretização dos direitos previstos; não se garante a igualdade em direito constitucional, em um contexto de desigualdade social (GARGARELLA; COURTIS, 2009, p. 17). Em alguma medida, a nova Constituição Política do Estado Boliviano, aponta para a necessidade de alterações mais profundas dessas bases materiais.

Roberto Viciano Pastor e Rubén Martínez Dalmau também contribuem na caracterização dos elementos que, segundo eles, seriam materiais comuns ao novo constitucionalismo latino-americano, movimentando o debate com subsídios que chamam a atenção para a concepção de um novo aporte 
constitucional. Diferenciaremos da denominação dos autores, quanto ao conceito "material", e utilizaremos o termo "estruturante", aparentemente mais abrangente, visto que analisaremos elementos que tendem a alterar, além de outros pontos, também o aspecto material das estruturas de poder.

As reivindicações dos movimentos populares - estimuladores $\mathrm{e}$ protagonista destas novas formatações constitucionais, e dos processos geradores desse fato político - têm grande influência nas disposições normativas. Grupos que eram marginalizados, ao longo da história social e jurídica do país, devido à forte herança colonial, conquistam espaços no rearranjo atual das forças políticas, conforme destacado.

A análise que será realizada pautará temas considerados centrais ao tratar de uma Constituição que se pretende instrumento de hegemonia de um projeto popular na América Latina.

2.3.2.3.1. A diversidade democrática na Constituição boliviana

A forma de governo é pautada no desenvolvimento da prática democrática, permeada pelas diretrizes da interculturalidade. Há um estimulo e reconhecimento de variadas formas democráticas, desde a representativa, passando pela participativa e a comunitária. É importante ressaltar, ainda, o destaque dado à equidade de gênero (MARTINEZ DALMAU; VICIANO PASTOR, 2014) para a prática da atividade democrática ao longo da Constituição ${ }^{136}$.

\footnotetext{
${ }^{136}$ As referências à equidade de gênero aparecem em inúmeros dispositivos constitucionais para ressaltar a necessária paridade. Vide artigos 8, 14, 26, 72, 79, 174, 210, 270 e 278.
} 
"Artículo 11.

I - La República de Bolivia adopta para su gobierno la forma democrática participativa, representativa y comunitaria, con equivalencia de condiciones entre hombres y mujeres."

II - La democracia se ejerce de las siguientes formas, que serán desarrolladas por la ley:

1. Directa y participativa, por medio del referendo, la iniciativa legislativa ciudadana, la revocatoria de mandato, la asamblea, el cabildo y la consulta previa. Las asambleas y cabildos tendrán carácter deliberativo conforme a Ley.

2. Representativa, por medio de la elección de representantes por voto universal, directo y secreto, conforme a Ley.

3. Comunitaria, por medio de la elección, designación o nominación de autoridades y representantes por normas y procedimientos propios de las naciones y pueblos indígena originario campesinos, entre otros, conforme a Ley."

A própria Constituição já apresenta as definições do que considera cada um dos tipos democráticos previstos, e a democracia representativa já não é a única referência legitima de prática democrática. Assim, o Estado boliviano através dessa diversidade democrática, alimenta o caráter de soberania popular latente e a intervenção concreta dos povos na realidade e cotidiano da sociedade.

Ao reproduzir inúmeras formas democráticas de governo, o Estado boliviano se abre para uma dinâmica civilizatória no cotidiano de seu povo, que vai desde a cosmovisão e interação indígena na seleção de autoridades, até os processos de assembleias operárias ou mesmo escolha de representantes políticos. Uma vez mais, o pluralismo é característica marcante da ressignificação dada à democracia.

[...] las distintas formas de la democracia, representativa, directa y comunitaria. La democracia retorna al devenir de la acción política y a la forma primordial de deliberación: la asamblea. Se rompe entonces el monopolio de la clase política, 
politizando el ejercicio mismo en todos los ámbitos de la gestión social. La democracia ya no es de pocos sino de todos. Los muchos ejercen su mayoría en dialéctica con las minorías, dialéctica donde se pone en escena la trama de los intereses y las perspectivas, lugar donde se da la ocasión de la síntesis política. (Prada, 2010, p. 111).

Quanto à democracia representativa e ao presidencialismo na Bolívia, algumas modificações ocorreram com a promulgação da nova Constituição.

El Estado boliviano está regido por un sistema de gobierno presidencialista, donde el Presidente del Estado es la cabeza del Órgano Ejecutivo, representante de la unidad nacional y del poder político, ya que es directamente elegido por la población mediante sufragio universal, obligatorio, directo, libre y secreto; mayoría absoluta de votos; y si es necesario mediante una segunda vuelta electoral (Artículo 166), sin la necesidad que intermediarios, como la Asamblea Legislativa Plurinacional, sea partícipe de la elección, puesto que ésta, es también elegida directamente por el pueblo (CENTRO DE ESTUDIOS CONSTITUCIONALES, 2013).

Assim, o exercício da democracia representativa é verificado pelo voto universal, direto, secreto, obrigatório e fortalecido na Bolívia por mais uma estrutura estatal, o Poder Eleitoral ${ }^{137}$ ou Órgão Eleitoral Plurinacional ${ }^{138}$. Esse órgão é uma ferramenta institucional que dará condições de garantir o exercício de direitos democraticamente estabelecidos pela vontade dos cidadãos/ãs. Além de organizar os procedimentos necessários aos processos eleitorais na

\footnotetext{
137 "Un tercer ejemplo de una institución compartida de importancia crucial para la construcción de la nueva democracia boliviana es el Órgano Electoral Plurinacional (art. 245 y siguientes), que es el cuarto órgano de soberanía al lado del Legislativo, Ejecutivo y Judicial. Su competencia general consiste en controlar y supervisar los procesos de representación política. Más que una competencia es un desafío muy exigente, dada la complejidad de la representación política en la nueva Constitución. Incluye no solamente diferentes escalas de democracia representativa (nacional, departamental, municipal), sino también distintas formas de organización de intereses (partidos y agrupaciones ciudadanas) y variadas formas de democracia (representativa, participativa y comunitaria)". (SOUSA SANTOS, 2010, p. 95).

${ }^{138}$ Artigo 205 da Constituição Boliviana.
} 
Bolívia (no Executivo, Legislativo e Judiciário), inclusive aqueles sufrágios que extrapolam a lógica da democracia representativa ${ }^{139}$.

A democracia direta e participativa, como o próprio nome identifica, não requer a mediação de representantes para o seu exercício; ela representa a possibilidade de ampliação da participação popular na construção e nas decisões dispostas na sociedade, podendo complementar-se com a democracia representativa eventualmente.

A própria Constituição prevê mecanismos de exercício da democracia direta e participativa. Um deles é o referendo, em que o cidadão/ã decidirá a respeito de uma temática de interesse público nacional, departamental ou municipal por meio do voto. Já a iniciativa legislativa cidadã, possibilitando aos/às cidadãos/ãs apresentarem diretamente ao Legislativo um projeto de lei. No que tange à possibilidade da revogação de mandato, o povo decidirá se determinado representante continuará o exercício do seu mandato ou será retirado, devendo ter transcorrido no mínimo o tempo referente à metade do mandato $^{140}$. Há outros mecanismos como a assembleia e o cabildo. As decisões tanto das assembleias, quanto dos cabildos não são automaticamente vinculantes ao Estado, mas devem ser levadas em consideração para a deliberação das questões ali decididas. $O$ reconhecimento desses instrumentos na democracia direta e participativa é uma novidade no constitucionalismo boliviano. "Mediante esse mecanismo, a cidadania - através de reuniões públicas - pronunciam-se diretamente sobre políticas e assuntos de interesse coletivo" (Tradução livre) (CENTRO DE ESTUDIOS CONSTITUCIONALES, 2013). Por fim, a Constituição ainda prevê a consulta prévia aos povos indígenas originários campesinos, conforme já destacado, influência direta da Convenção 169 da OIT, a qual determina que os grupos afetados pela ação do Estado em seus territórios sejam ouvidos e tenham determinado poder de decisão a respeito de medidas administrativas ou legislativas que irão afetá-los.

\footnotetext{
${ }^{139} \mathrm{Na}$ democracia comunitária a aplicação da consulta prévia aos povos indígenas originários campesinos, decorrente de alguma ação do Estado nos seus territórios, será organizada pelo órgão eleitoral plurinacional.

${ }^{140}$ Essa regra relacionada à revogação do mandato não vale para as eleições do Judiciário, de acordo com o artigo 240 da Constituição Boliviana.
} 
O exercício da democracia comunitária vai além da perspectiva do individuo, e remete às práticas de povos e comunidades indígenas originários campesinos que passam a ter o reconhecimento do Estado Plurinacional. Os diferentes povos e comunidades terão as formas organizativas e procedimentos próprios para exercerem suas práticas democráticas comunitárias; nesses casos, não existe um padrão. Assim, as autoridades e lideranças serão nomeadas nas comunidades para exercerem funções inerentes ao seu papel comunitário. Mesmo essas eleições serão supervisionadas pelo órgão eleitoral plurinacional para que sejam respeitadas as normas e os procedimentos ${ }^{141}$ peculiares da comunidade sem haver interferências externas prejudiciais ao desenvolvimento democrático ${ }^{142}$.

Para Luis Tapia, a redefinição da prática democrática a partir da Constituição poderá cumprir uma tarefa fundamental para a sociedade boliviana ao enfrentar as práticas imperialistas e do próprio capitalismo; nesse sentido a democracia poderá ser útil para tensionar esses pontos, visto que tem potencial para isso (2009a, p. 91).

Assim, uma sociedade que pensa um modelo democrático, intergovernamental, igualitário, em conjunto com formas comunitárias de autogoverno, deve potencializar também, mecanismos democráticos que inibam práticas imperialistas e intervenções do capitalismo. Só dessa forma

\footnotetext{
${ }^{141}$ Artigo 211 da Constituição boliviana.

142 "A las garantías del ejercicio de los derechos a la autonomía, el autogobierno y a sus instituciones propias, que hace el artículo 2 de la nueva CPE boliviana, se debe agregar lo establecido en el artículo 11, parágrafo II, numeral 3, que reconoce la democracia comunitaria que consiste en la "elección, designación o nominación de autoridades y representantes por normas y procedimientos propios de las naciones y pueblos indígena originario campesinos, entre otros, conforme a Ley". Este artículo justifica el carácter comunitario del nuevo modelo de Estado boliviano. En su aplicación los pueblos indígenas pueden ser parte de los órganos del poder público eligiendo, designando o nominando sus representantes a través de normas y procedimientos propios. A tiempo de reconocerse como válidos los procedimientos y sistemas tradicionales de democracia propia de los indígenas, el Estado reconoce las autoridades que, por esas posibles vías, designen. Si bien estos elementos representan avances importantes, el Estado no deja de tener participación en el ejercicio de este derecho. En el caso electoral, por ejemplo, los sistemas de democracia comunitaria de elección de representantes a los órganos públicos, deben ser consignados por escrito y aprobados por el órgano electoral departamental respectivo para la "supervisión "de la efectiva aplicación de los mismos (art. 211, CPE, y la Ley del Régimen Electoral $n^{\circ}$ 26/10). Un sistema comunitario de democracia que podríamos denominar "mixto" o con control estatal" (TAMBURINI, 2012, p.255).
} 
terá condições de lograr a efetivação plena das variadas vertentes democráticas estabelecidas.

2.3.2.3.2. Autonomia e a reorganização territorial do Estado

A Constituição aborda, de forma desafiante, o estabelecimento de regimes autonômicos garantidores de uma descentralização do poder do Estado, sem perder a unidade em torno do território boliviano. A nova estrutura do Estado Plurinacional da Bolívia prevê, inclusive, um Ministério de Autonomias para tratar o tema. A reorganização autonômica, exceto no nível nacional, ou melhor, plurinacional, está estruturada em departamentos, regiões, províncias, municípios e territórios indígena originários campesinos ${ }^{143}$.

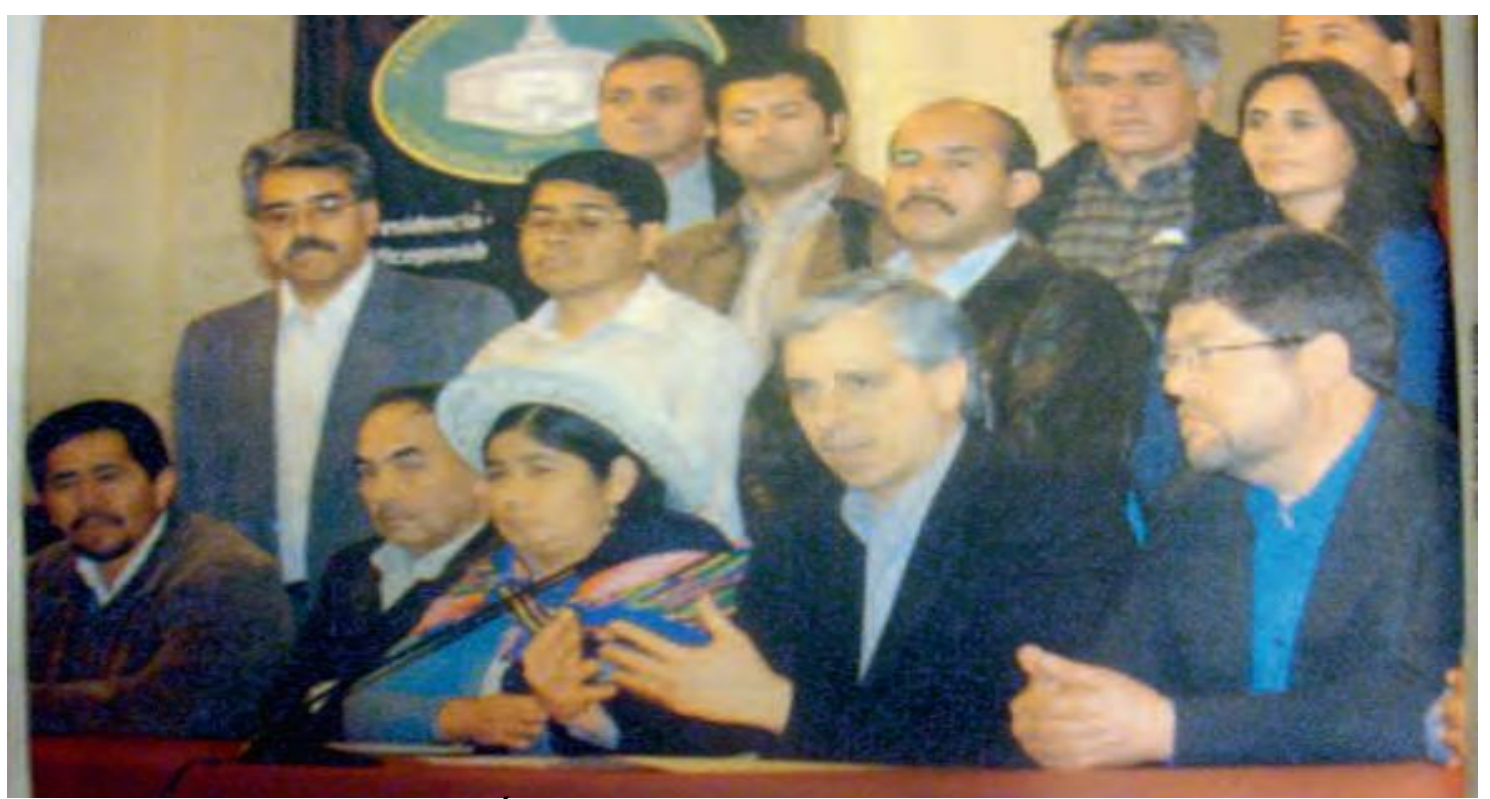

Foto 09 - O Vice-presidente Álvaro García Linera explica o acordo alcançado sobre as autonomias. Projetam-se quatro niveles: o departamental, o regional ou provincial, o municipal y o indígena.

Fonte: (HEMEROTECA, 2007d)

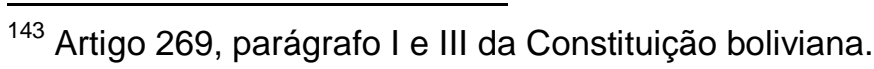


Alguns desses entes são tratados desde uma perspectiva de descentralização administrativa e outros como entidades territoriais autônomas. A autonomia permitirá que ocorram eleições diretas das respectivas autoridades pelos cidadãos/ãs nessas unidades territoriais. Ali será exercida a função fiscalizadora, executiva e legislativa dentro daquela jurisdição e, seguindo as competências cabíveis, atribuídas ao tipo de unidade territorial. Isso delimitará a forma que o Estado distribui suas instituições e parcela do poder em seu espaço geográfico.

Na Bolívia, os Departamentos formam as unidades territoriais inferiores ao nível central do Estado; existem nove Departamentos naquele país: Tarija, Pando, Beni, Potosí, Chuquisaca, La Paz, Santa Cruz, Cochabamba e Oruro.

Em decorrência de ações políticas regionais, no início do século XXI, que pleitearam maior autonomia departamental para a obtenção de faculdades legislativas e executivas próprias, a Constituição previu esta possibilidade. Assim, a reorganização posta na Constituição permite a coexistência de Departamentos descentralizados e ao mesmo tempo Departamentos autônomos, caso tenham logrado o pleito autonômico mediante referendo levado à população ${ }^{144}$.

Os departamentos estão divididos em províncias, que são responsáveis por alguns assuntos locais; elas também são consideradas entidades territoriais descentralizadas, além dos municípios, que já faziam parte da estrutura institucional boliviana e mantem sua existência. Cabe ressaltar que os

\footnotetext{
144 As autonomias departamentais foram pleitos fortes das elites afortunadas bolivianas. Contudo, não aprovaram o texto constitucional autonômico que pleiteavam, mas ainda sim conseguiram manter sua base econômica sedimentada. A passagem do artigo de Marxa Chávez evidencia isso: "Pero el hecho que sus proyectos más radicales hayan sido temporalmente suspendidos se debe también a la inclusión de la autonomía departamental, pivote de la rearticulación de dicho bloque, en la Nueva Constitución Política del Estado. Tampoco se ha visto muy afectado su núcleo duro, la propiedad de las tierras, y su participación en el sector financiero y agroindustrial" (CHÁVEZ; NEHE, 2011, p. 93). Atualmente os 09 Departamentos bolivianos manifestaram o interesse pelo regime autonômico. Quatro desses no referendo de 2006 e cinco no referendo de 2009.
} 
municípios podem se converter em autonomias indígenas originárias campesinas.

Incumbe chamar a atenção para as regiões, que representam parte do território do Estado que se agrega por alguma afinidade linguística, étnica, cultural, etc. Logo, a região formada por vários municípios ou províncias com continuidade geográfica e sem transcender departamentos poderá constituir autonomia regional ${ }^{145}$. As regiões possuiriam faculdade de gestão e planejamento, mas não legislariam regionalmente. Cabe salientar, que uma das grandes perdas na garantia de direitos do que havia sido aprovado em Oruro, para o que ficou como texto final constitucional, foi a impossibilidade de mexer nos limites territoriais limitados aos Departamentos. A forma que as regiões, por exemplo, estão configuradas como entes territoriais autônomos não podem romper as fronteiras departamentais, nem assumir competências sem a autorização do Conselho Departamental ${ }^{146}$. Isso faz com que Departamentos, ainda controlados por castas da aristocracia boliviana, mantenham poder concentrado e dificultem a modificação das estruturas de poder do Estado.

Não resta dúvida, que os territórios indígenas originários campesinos são as maiores novidades da organização territorial boliviana. Eles buscam partir de uma reconstrução estatal que não sobrepõe às instituições liberais, formais, esquizofrênicas para gerirem o funcionamento dos territórios dos povos e comunidades indígena originário campesinos. Bartolomé Clavero vai além, e ressalta que a autonomia indígena é anterior à Constituição, decorrente de direito dos povos indígenas à livre determinação, e, em consequência, com natureza autonômica distinta da departamental (2010, p. 101).

De esta forma la Constitución garantiza que las naciones y pueblos indígena originario campesinas, fundamentado en su existencia precolonial y el dominio ancestral de sus territorios, gocen de libre determinación y autonomía, que consiste, entre otros elementos, en la consolidación de sus entidades

\footnotetext{
${ }^{145}$ Artigo 280, parágrafo I, da Constituição boliviana.

${ }^{146}$ Artigo 280, I e III, da Constituição boliviana.
} 
territoriales (CENTRO DE ESTUDIOS CONSTITUCIONALES, 2013).

Assim, cada nação exercerá seu autogoverno consolidando as entidades territoriais, as quais não devem extrapolar territorialmente os Departamentos, além das normas, procedimentos e autoridades próprias dos respectivos povos e nações ${ }^{147}$. Esses povos serão submetidos a uma consulta para tratar da efetivação autonômica ou não. Caso não optem pela autonomia, as comunidades continuarão a vivência própria nos seus municípios, distritos municipais ou mesmo nos territórios indígena originário campesino, "os quais mediante um trâmite administrativo, adquirem a qualidade de Terras Comunitárias de Origem ou TCO” (Tradução livre) (YAKSIC, 2010, p. 134).

Importante destacar que as entidades territoriais autônomas não se subordinam entre si, sendo que suas disposições normativas tem a mesma hierarquia, conforme destaca o artigo 276 da Constituição. No entanto, as competências das entidades territoriais, em geral, estão submetidas a uma hierarquia normativa pautada na própria Constituição boliviana frente a outras normas.

Assim, conforme prescreve o artigo 410 da Constituição boliviana:

Artículo 410.

I. Todas las personas, naturales y jurídicas, así como los órganos públicos, funciones públicas e instituciones, se encuentran sometidos a la presente Constitución.

II. La Constitución es la norma suprema del ordenamiento jurídico boliviano y goza de primacía frente a cualquier otra disposición normativa. El bloque de constitucionalidad está integrado por los Tratados y Convenios internacionales en materia de Derechos Humanos y las normas de Derecho Comunitario, ratificados por el país. La aplicación de las normas jurídicas se regirá por la siguiente jerarquía, de acuerdo a las competencias de las entidades territoriales:

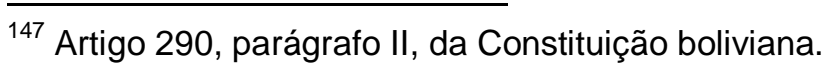


1. Constitución Política del Estado.

2. Los tratados internacionales.

3. Las leyes nacionales, los estatutos autonómicos, las cartas orgánicas y el resto de legislación departamental, municipal e indígena.

4. Los decretos, reglamentos y demás resoluciones emanadas de los órganos ejecutivos correspondientes.

A primazia da Constituição Política do Estado Plurinacional da Bolívia demonstra ser ela a primeira norma aplicável, gozando de preferência no momento da consubstanciação do direito e da refutação de ações que contrariam seus preceitos. Ou seja, a Constituição prevalecerá perante o ordenamento jurídico vigente e o sistema de justiça atual.

A organização territorial na nova Constituição Política do Estado Plurinacional da Bolívia, apresenta-se da seguinte forma, conforme disposto em desenho:

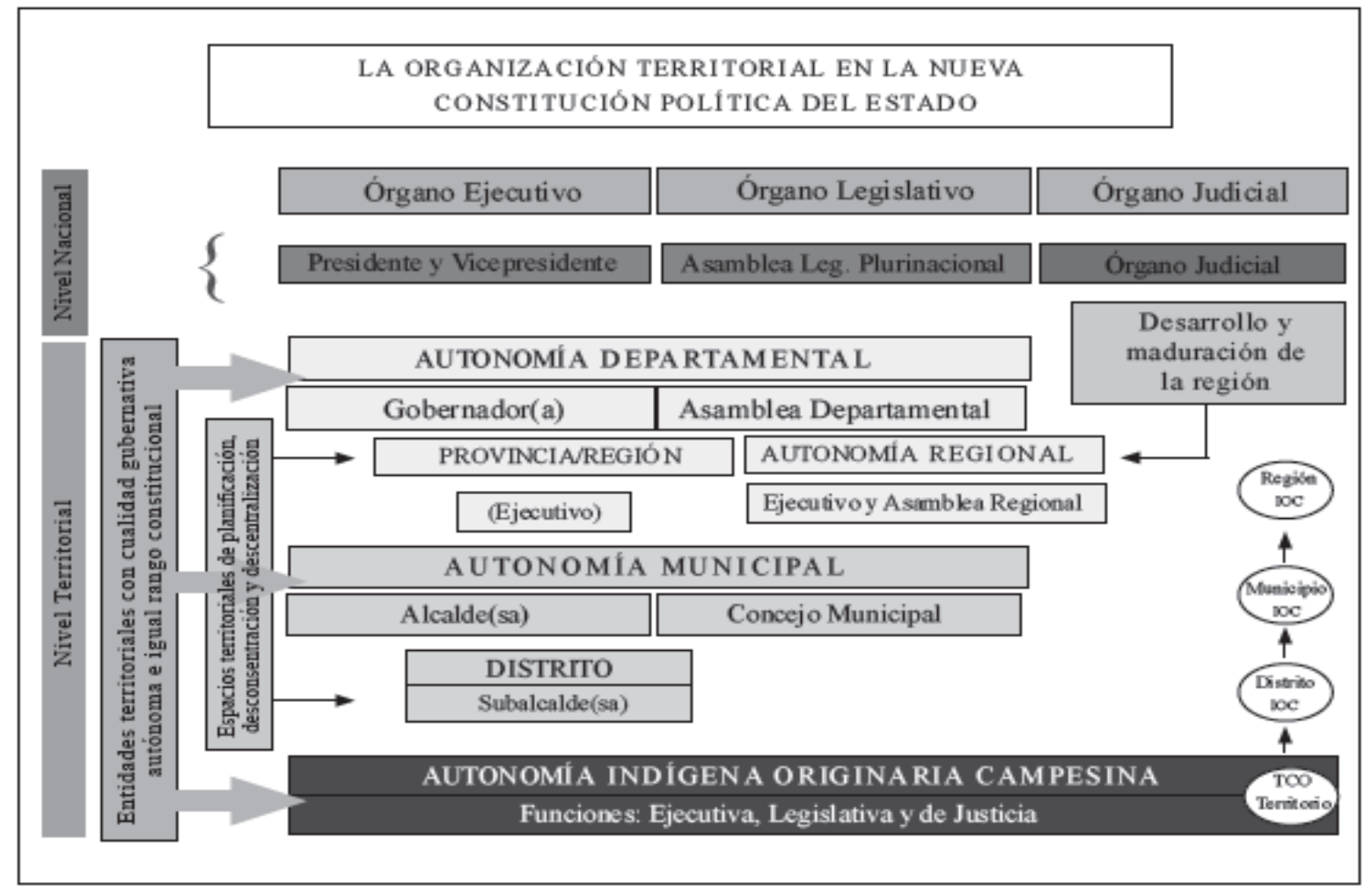

Tabela 05 - A organização territorial na nova Constituição Política do Estado. 
Fonte: (YAKSIC, 2010, p. 133).

O Estado, em seu nível central, garantirá uma parcela de recursos a serem transferidos às entidades territoriais autônomas ${ }^{148}$. Assim, permitirá que se tenha o mínimo para desenvolver essas unidades e manter seu funcionamento a partir da Lei Marco de Autonomias e Descentralização (Lei 031 de 19 de julho de 2010), prevista na própria Constituição, na parte das disposições transitórias, onde estava estabelecido o prazo para a sua aprovação.

\subsection{A reestruturação jurisdicional}

Ao tratar do indígena, a Constituição boliviana não o/a destaca como um mero sujeito individual de direitos, mas concebe uma estrutura constitucional orientada também a partir desse grupo social. $O$ estabelecimento de uma jurisdição indígena originária campesina ${ }^{149}$ faz esse recorte resgatado pelo pluralismo instituído constitucionalmente. Através desse conceito, abandona-se aquele da "justiça comunitária ${ }^{150 ", ~ q u e ~ t r a z i a ~ a o ~ i m a g i n a ́ r i o ~ s o c i a l ~}$ uma representação da colonialidade neoliberal trabalhada na academia e por meio das normas de um modelo de justiça até então vigente. Da mesma forma,

\footnotetext{
${ }^{148}$ Artigo 340 da Constituição Boliviana

149 “Artículo 190. I - Las naciones y pueblos indígena originario campesinos ejercerán sus funciones jurisdiccionales y de competencia a través de sus autoridades, y aplicarán sus principios, valores culturales, normas y procedimientos propios".

${ }^{150} \mathrm{O}$ conceito de Justiça comunitária surge na Bolívia a partir de um projeto encabeçado pelo Ministério da Justiça daquele país, em 1995, sob o título de "Projeto de Reforma Judicial", decorrente de um acordo entre o governo da Bolívia e a Associação Internacional de Fomento.
} 
isso está evidenciado na previsão de uma jurisdição agroambiental ${ }^{151}$, em que é estabelecido um tribunal especializado para tratar de temática, tão relevante, não só ao povo boliviano, mas também para a sociedade internacional.

Isso demonstra uma inovação do constitucionalismo boliviano ao conceber instituições com importância estratégica para o tipo de desenvolvimento a que se propõem. Ao tratar de uma jurisdição agroambiental, atenta-se para uma questão ignorada e colocada em segundo plano ao longo da história. A centralidade do exame jurídico, não é mais a mera defesa patrimonial ou da vida individualizada do sujeito de direito, mas a busca do bem estar da relação homem/mulher-natureza. Por isso, a importância em estabelecer uma jurisdição própria para lidar com a questão ambiental, territorial, recursos naturais, biodiversidade, e a relação com os sujeitos indígenas originários campesinos, como aborda a Constituição. Ademais, os magistrados/as do Tribunal Agroambiental serão eleitos mediante sufrágio universal, segundo determinados procedimentos, ${ }^{152}$ orientados a julgar prezando a função social, a sustentabilidade e a interculturalidade.

A jurisdição agroambiental incidirá tanto ao sujeito, quanto a um território ou mesmo uma matéria específica relacionada, evidentemente, aos temas agrários ou ambientais. Certo que, a depender da situação concreta, haverá conflito de competência com outras jurisdições, como a jurisdição indígena originária campesina, por exemplo. Diante dessa situação, princípios de auto-restrição de competências e de cooperação interjurisdicional, amparados pelas garantias do pluralismo jurídico, podem contribuir na resolução da lide. Caso isso não seja suficiente, a saída é a resolução do conflito por meio do Tribunal Constitucional Plurinacional, conforme prevê o artigo 202 da Constituição.

A jurisdição indígena originária campesina, já citada, também apresenta elementos próprios e distintos de concepção da Justiça. Apresentará

151 "Artículo 186. El Tribunal Agroambiental es el máximo tribunal especializado de la jurisdicción agroambiental. Se rige en particular por los principios de función social, integralidad, inmediatez, sustentabilidad e interculturalidad."

152 Cf. artigo 188 da Constituição boliviana. 
as bases, nas quais esses povos exercem suas funções jurisdicionais, abrindo um diálogo que atravessa as bases, inclusive, epistemológicas e jurídicas tradicionais para o acesso à Justiça.

O cenário de atuação dessa jurisdição é o mais diverso possível, pois variará, conforme os procedimentos, normas e vivencias dos povos que estarão submetidos a ela, consistindo na aplicação do pluralismo jurídico em essência. A intenção não é fragmentar os variados povos e comunidades que compõem o Estado boliviano, mas garantir que os mecanismos de justiça funcionem respeitando as subjetividades específicas das distintas nações.

Os sistemas políticos, econômicos e jurídicos das várias nações dos povos bolivianos estão ligados, via de regra, à territorialidade ${ }^{153}$ que ocupam e a partir dessa reprodução social, se dará a jurisdição indígena originário campesina. Assim, essa jurisdição realizar-se-á nos respectivos territórios dessas comunidades e povos indígenas originários campesinos. Logo, as jurisdições serão várias e paritariamente consideradas frente às outras que compõem os órgãos do sistema de Justiça na Bolívia. Ela não será regida por temática específica, nem obedecerá a princípios previamente estipulados, mas àqueles valores culturais, procedimentos e normas próprias das comunidades. As autoridades/lideranças locais cumprirão o papel de magistrados, sendo responsáveis por interpretação das normas e decisão dos casos.

Certamente, existem distintas formas de vivência humana que devem ser consideradas e têm o potencial de gerar tensões entre os conviventes. Essas decisões não podem desrespeitar princípios fundamentais, ou garantias mínimas, da Constituição, extrapolando medidas que ferem a razoabilidade e geram graves opressões aos submetidos a elas. Das decisões desarrazoadas caberão recursos ao Tribunal Constitucional Plurinacional ${ }^{154}$ competente para julgar o caso e respeitar a interculturalidade devida na lide.

\footnotetext{
${ }^{153}$ Não que o território seja uma condição para acessar a jurisdição indígena originário camponesa.

${ }^{154}$ Artigo 202, ponto 8, da Constituição boliviana.
} 
O pluralismo jurídico nascerá dessa diversidade, sem descuidar das garantias mínimas devidas aos seres humanos e à natureza, as quais criam o elo entre esses povos e garantem legitimidade às suas decisões.

As jurisdições ordinárias, especializadas e agroambientais estarão subordinadas ao controle administrativo e financeiro de um Conselho da Magistratura ${ }^{155}$, formado por sufrágio universal de membros indicados pela Assembleia Legislativa Plurinacional. Preza-se assim, pelo princípio da transparência e da participação cidadã na confecção e fiscalização das instituições.

Cabe ressaltar ainda, o papel inovador do Tribunal Constitucional Plurinacional ${ }^{156}$ e o seu exercício do controle de constitucionalidade. A composição do Tribunal admite magistrados/as eleitos a partir da plurinacionalidade e representando tanto o sistema ordinário como indígena originário campesino de Justiça. Contudo, uma questão problemática que está posta na eleição dos magistrados indígenas nos Tribunais, por exemplo, é que eles/as são eleitos, não a partir do território indígena autonômico que ocupam, mas do Departamento onde estão situados. Ou seja, é a escolha de membros da justiça indígena intermediada por um ente do Estado, ao invés de ser somente o território que ocupa ${ }^{157}$.

De toda forma, a tarefa do Tribunal é robusta e desafiante, pois deve harmonizar os diversos enfoques jurídicos que chegam das distintas visões de mundo e jurisdições, com a sabedoria para decidir a partir de critérios que respeitem a interculturalidade e o pluralismo envolvido. Ele deve também exercer a função de grande guardião da Constituição a fim de assegurar 0 cumprimento dos direitos ali estabelecidos.

\footnotetext{
${ }^{155}$ Artigo 193 da Constituição boliviana.

${ }^{156}$ Artigo 196 da Constituição boliviana

157 "Artículo 182. II. La Asamblea Legislativa Plurinacional efectuará por dos tercios de sus miembros presentes la preselección de las postulantes y los postulantes por cada departamento y remitirá al órgano electoral la nómina de los precalificados para que éste proceda a la organización, única y exclusiva, del proceso electoral."
} 
2.3.2.3.4. Os caminhos rumo à descolonização constitucional e a plurinacionalidade.

Ao refletir, de uma forma geral, sobre os processos constitucionais dos países latino-americanos até os dias de hoje, observar-se-á um reflexo da estrutura e conteúdo liberal que perdura constitucionalmente desde o século $\mathrm{XIX}$. Um dos desafios do novo constitucionalismo latino-americano é radicalizar o enfrentamento com este aparato colonizador ainda presente.

A descolonialidade parte de uma prática política com cunho epistêmico distinto do dominante, o qual deve permear sua ação a partir do processo constitucional, das relações de poder e o do desenvolvimento do saber na América Latina. Dessa forma, ela pode se apresentar como um mecanismo de resistência dos povos e das nações indígena originária campesina em estratégia de mobilização popular para mudanças paradigmáticas.

O desafio colocado é o de possibilitar uma insurgência política e epistêmica, questionadora tanto da sistemática fundante do capitalismo e suas bases, quanto de uma racionalidade formal indolente, a qual só concebe um formato pronto e acabado de Estado. Conforme dispõe Catherine Walsh, a expectativa que parte da Bolívia, a partir do novo aporte político e constitucional, é a de "refundar o Estado a interculturalizar, plurinacionalizar e descolonizar suas estruturas e instituições" (Tradução Livre) (WALSH, 2008, p.135).

Não é por acaso, que nos dispositivos constitucionais bolivianos, os termos anticolonial, intercultural e plurinacional estão explicitamente presentes. Essa Carta Constitucional desestabiliza a racionalidade moderna liberal concebida historicamente. A reconstrução do Estado plurinacional a partir da 
interculturalidade possibilita o giro descolonizador, por ora, realizável. O papel do Estado passa a ser forjado por povos antes excluídos do processo político e altera, em parte, as estruturas de poder estabelecidas historicamente. Há uma demanda real, e agora jurídica, de reconhecimento de uma pluralidade garantida em diversos setores como: econômico, político, social, cultural e jurídico. Isso, já é o suficiente para modificar o quadro anterior, mas não se sabe, se o suficiente para possibilitar uma práxis da libertação, tal como desenvolvido no conceito de Enrique Dussel.

Assim, o novo constitucionalismo latino-americano traz a baila a emergência de grupos sociais e temas que são invisibilizados pelo paradigma moderno e liberal do direito e das próprias estruturas constitucionais clássicas. Não se trata de estabelecer direitos abstrata e genericamente, mas agora a questão é ampliar direitos, resignificá-los e reestruturar o Estado, a partir dos grupos que os detêm e da realidade social vivenciada. Mais do que isso, como ressalta Gargarella, a nova Constituição boliviana responde a um objetivo crucial "[...] a integração política e social de um setor majoritário da população o setor indígena - tradicionalmente excluído do poder pelas minorias governantes (tradução livre) (2011, p. 88)".

Logo, só com o advento do que estamos considerando como o "novo constitucionalismo latino-americano", observados na Constituição Equatoriana de 2008 e Boliviana de 2009, principalmente, que se constata o elemento da plurinacionalidade na seara constitucional. $O$ significado desse reconhecimento rompe com a mera concessão de direitos, que até então consistia em uma realidade e propõe uma refundação do Estado passando pelo processo constituinte. Além do reconhecimento dos povos indígenas historicamente excluídos, eles passam do "papel" de figurantes ao de protagonistas desse processo, onde se inicia o "funeral" da malfadada herança colonial. Há um reconhecimento transversalizado desses sujeitos perante a estrutura dos poderes, que passam a ser constituídos diferentemente do padrão liberal herdado. 
(...)la voluntad constituyente de las clases populares, en las últimas décadas, se manifiesta en el continente a través de una vasta movilización social y política que configura un constitucionalismo desde abajo, protagonizado por los excluidos y sus aliados, con el objetivo de expandir el campo de lo político más allá del horizonte liberal, a través de una institucionalidad nueva (plurinacionalidad), una territorialidad nueva (autonomías asimétricas), una legalidad nueva (pluralismo jurídico), un régimen político nuevo (democracia intercultural) y nuevas subjetividades individuales y colectivas (individuos, comunidades, naciones, pueblos, nacionalidades). Estos cambios, en su conjunto, podrán garantizar la realización de políticas anticapitalistas y anticoloniales. (SOUSA SANTOS, 2010, p. 77)

Por mais que os pesquisadores trabalhem com categorias como 0 multiculturalismo, ressaltando a integração cultural, presente nas Constituições da década de 80 e 90 do século $X X$, nesse atual momento do novo constitucionalismo latino-americano, não é cabível mais esse conceito (ZIZEK, 1997). A forma de utilização do multiculturalismo é mera tentativa de afirmar a diferença, não modificando em absoluto a estrutura de poder político e econômico estabelecida. Não se trata de integrar o "Outro" ao sistema, mas afirmar a alteridade do "Outro" (latino-americano excluído), intervir e conceber um novo sistema.

A "exotização" do "Outro", provocada pelo multiculturalismo, não propicia a formulação de uma perspectiva constitucional latino-americana emancipatória $^{158}$. O discurso multicultural neoliberal tem como retaguarda a exclusão, a subordinação, o controle das estruturas capitalistas possibilitado pelo binômio modernidade-colonialidade. A Constituição Boliviana de 2009, como salientado, apresenta um viés não fundamentado na mera afirmação multicultural ou reconhecimento pluricultural, mas interfere nas estruturas de

\footnotetext{
158 "El multiculturalismo, según ha sido definido en el contexto norteamericano de construcción de un nuevo pacto nacional, no puede ser trasladado mecánicamente a América Latina (...) En un país como Estados Unidos, existe un "mito del multiculturalismo", un mito nuevo que habla igualmente del deseo de justicia social pero a través del lenguaje de la separación, de la delimitación de fronteras étnicas nítidas en un país donde la condición de mestizo nunca se planteó como una realidad social, política y cultural (...) Al mismo tiempo, crece la comprensión de que el multiculturalismo implica una exotización del "otro dominado" y la atribución por parte de los estadounidenses de lo que son las diferencias esencialmente legítimas." (LINS RIBEIRO, 2005, p. 47).
} 
poder. Esse é um grande diferencial desse contexto, o qual caracterizamos o novo constitucionalismo latino-americano.

Assim, desmistifica-se a integração cultural proveniente do sistêmico multiculturalismo, e constata-se a prevalência da interculturalidade. Vislumbrase, de fato, uma produção social e política do Direito, propiciado pela Constituição Boliviana e protagonizado por parte dos povos, classes e grupos sociais oprimidos, que passam a dialogar entre si e ativam o conceito de interculturalidade (WALSH, 2009a). Traz uma proposta diferente dos conceitos prefixados com o "multi" ou o "pluri", mas representa algo em construção. Não trata de uma interculturalidade funcional que não questiona a estrutura posta, mas um interculturalidade crítica, tal qual considerada por Fidel Tubino.

Mientras que en el interculturalismo funcional se busca promover el diálogo y la tolerancia sin tocar las causas de la asimetría social y cultural hoy vigentes, en el interculturalismo críticos se busca suprimirlas por métodos políticos no violentos. La asimetría social y la discriminación cultural hacen inviable el diálogo intercultural auténtico (2005).

O desenvolvimento de uma interculturalidade crítica afeta a estrutura de poder estabelecida visto que possibilita uma construção política, social e por que não, jurídica, desde os sujeitos oprimidos e colonizados no decorrer da história das Américas. Assim, permite um enfrentamento real desses grupos contra-hegemônicos frente à estrutura liberal concebida e permeada pelo desenvolvimento do capitalismo com bases coloniais. Isso possibilita uma modificação e reposicionamento institucional, o qual visibiliza estes "novos" grupos que ganham força na arena política.

Tratar da plurinacionalidade, em um contexto latino-americano é reconhecer a coexistência de grupos étnicos societários distintos, originários ou não. O Estado Plurinacional boliviano aponta os grupos e os direitos que almeja abarcar, além de reforçar o aspecto comunitário. 


\begin{abstract}
El resultado es que ese Estado Plurinacional no solamente que reconoce la diversidad nacional y cultural, sino que es un Estado que está constituido con un contenido profundamente comunitario, desde sus formas básicas de organización en todos los niveles, como también en la forma en que estos pueblos leen su historia, su presente, sus luchas y su porvenir. Por lo tanto, no solamente hablamos de un Estado Plurinacional, sino de un Estado Plurinacional comunitario (GONSALVEZ , 2012, p. 153).
\end{abstract}

Não é por acaso, que cria condições materiais e estruturais ao prever um Tribunal Constitucional Plurinacional com a inclusão da jurisdição indígena $^{159}$, ou mesmo considera como princípios fundantes diante dos órgãos judiciários, o pluralismo jurídico e a interculturalidade, ${ }^{160}$ conforme já apresentado.

Essa perspectiva descolonizadora aparece também em outras esferas do Estado, como na estrutura organizativa do Poder Executivo, dentro do Ministério da Cultura criaram o inovador Vice-Ministério da Descolonização. Ele objetiva gerar possibilidades de discussões políticas e acadêmicas que abra novos padrões epistemológicos para além da reprodução educacional ocidental; além desse, há também o Vice-Ministério de Interculturalidade. Essas novas instituições representam um marco na formulação de políticas públicas na Bolívia.

As reflexões do tempo de resistência ao neoliberalismo transformaramse em propostas de mudança concreta nos tempos atuais. Como destaca Idon Chivi Vargas, a descolonização é o ajayu (espírito) e a despatriarcalização a q'amasa (energia) do processo. "O Estado não é um ente sobrenatural, nem é um leviatã, é só uma construção humana e seu suicídio como maquinaria

\footnotetext{
159 "Artículo 186. I - El Tribunal Constitucional Plurinacional estará integrado por Magistradas y Magistrados elegidos con criterios de plurinacionalidad, con representación del sistema ordinario y del sistema indígena originario campesino."

160 "Artículo 178. I. La potestad de impartir justicia emana del pueblo boliviano y se sustenta en los principios de independencia, imparcialidad, seguridad jurídica, publicidad, probidad, celeridad, gratuidad, pluralismo jurídico, interculturalidad, equidad, servicio a la sociedad, participación ciudadana, armonía social y respeto a los derechos."
} 
colonial e patriarcal é o fundo prático da descolonização e despatriarcalização" (Tradução Livre). (2012, p. 19).

O papel histórico e, agora, constitucional, do movimento indígena operário campesino é fundamental para a construção da política descolonizadora. Conforme o Estado Plurinacional da Bolívia, para que a descolonização das instituições ocorra, de fato, deverá ocorrer também a despatriarcalização. Tanto é que dentro do Vice-Ministério de Descolonização há uma Unidade de Despatriarcalização. No debate constituinte, essa temática foi muito debatida nas Comissões de Visão de País e de Educação. Tanto é que a fundamentação da base normativa do sistema educativo plurinacional segue essa lógica descolonizadora e despatriarcalizadora, como verificado na lei da Educação “Avelino Siñani-Elizardo Pérez" (Lei n070 de 2010).

Artículo 3 . (Bases de la educación). La educación se sustenta en la sociedad, a través de la participación plena de las bolivianas y los bolivianos en el Sistema Educativo Plurinacional, respetando sus diversas expresiones sociales y culturales, en sus diferentes formas de organización. La educación se fundamenta en las siguientes bases:

1. Es descolonizadora, libertadora, revolucionaria, antiimperialista, despatriarcalizadora y transformadora de las estructuras económicas y sociales; orientada a la reafirmación cultural de las naciones y pueblos indígena originario campesinos, as comunidades interculturales y afrobolivianas en la construcción del Estado Plurinacional y Vivir Bien.

(...)

Artículo 4 . (Fines de la educación)

6. Promover una sociedad despatriarcalizada, cimentada en la equidad de género, la no diferencia de roles, la no violencia y la vigencia plena de los derechos humanos.

Assim, a partir da promulgação da nova Constituição, o Estado boliviano se organiza desde uma estrutura diferenciada, criando programas e políticas estratégicas com 0 propósito de potencializar as práticas descolonizadoras e despatriarcalizadoras. Além dos exemplos já citados, criaram o Vice-Ministério de Saúde tradicional, o Vice-Ministério de Educação 
Intercultural, Vice-Ministério de Coordenação com Movimentos Sociais, dentre outras iniciativas que trabalham com o propósito refundador do Estado.

Isso contribui para que a nova Constituição boliviana ao enfrentar pontos inerentes à fundamentação de um Estado liberal, colonial e capitalista, ataque a figura ilusória da neutralidade constitucional. A Carta Magna questiona aspectos fundantes do liberalismo como: a forma da estruturação da tripartição de poderes, a não intervenção estatal na economia, a mera individualização de direitos, dentre outros. Desse modo, a Constituição do Estado Plurinacional da Bolívia apresenta a possibilidade de romper com variados pontos que compõem historicamente uma estrutura institucional colonizada.

\subsection{Economia e vivir bien}

Essas mudanças paradigmáticas serão fundamentais para que o Estado trilhe um caminho que considere e paute o vivir bien ou Sumaj qamaña ${ }^{161}$ na Bolívia. Esse conceito andino, crítico ao capitalismo e ao núcleo irracional da modernidade, traz valores comunitários da cosmovisão indígena, além de ressaltar a relação harmônica do homem-mulher com a "mãe terra". Logo, o vivir bien manifesta-se no modelo de Estado Plurinacional, no novo

\footnotetext{
161 "Aunque con distintas denominaciones según cada lengua, contexto y forma de relación, los pueblos indígena-originarios tienen la conciencia de un principio básico: "somos hijos de a madre tierra y de padre cosmos" y guardan profundo respeto por ellos. Desde el pueblo aymara-quechua la llamamos Pachamama (Madre Tierra) y Pachakama (Padre Cosmos), otros como el pueblo mapuche: Ñuke Mapu (Madre Tierra), para los Ngobe Bugle de Panamá: Meyedobo (Madre Tierra) o los Uros que siempre han vivido sobre las aguas dirán Qutamama (Madre Agua), que es la que les generó vida y los hermanos de la Amazonía dirán Madre Selva en sus respectivas lenguas. Pero ningún pueblo que guarda la sabiduría ancestral dice simplemente tierra, o planeta, o medio ambiente, hay una relación de familiaridad, de cariño, de saber que vive; más aún es nuestra madre" (HUANACUNI, 2012, p. 132).
} 
modelo territorial autonômico e no novo modelo econômico plural e comunitário.

Não se pode viver bem, se outras pessoas e seres vivos vivem mal. Da mesma forma, vivir bien não é o mesmo que viver melhor. Viver melhor está atrelado ao consumismo, ao egoísmo, ao individualismo, desinteresse pelos outros, ambição pelo lucro ao desconsiderar os povos e concentrar a riqueza em poucas mãos (HUANACUNI, 2012, p. 130). Trata-se da busca por um sistema civilizatório que aliará os conhecimentos ancestrais da cosmovisão indígena, propiciando um diálogo intercultural, sem ignorar o tempo histórico atual, com toda a sua complexidade e problemas a serem superados.

O vivir bien, mesmo como um objetivo almejado pelo Estado na sociedade plural, possui destaque constitucional na parte relacionada à organização econômica.

Artículo 313. Para eliminar la pobreza y la exclusión social y económica, para el logro del vivir bien en sus múltiples dimensiones, la organización económica boliviana establece los siguientes propósitos:

1. Generación del producto social en el marco del respeto de los derechos individuales, así como de los derechos de los pueblos y las naciones.

2. La producción, distribución y redistribución justa de la riqueza y de los excedentes económicos.

3. La reducción de las desigualdades de acceso a los recursos productivos.

4. La reducción de las desigualdades regionales.

5. El desarrollo productivo industrializador de los recursos naturales.

6. La participación activa de las economías pública y comunitaria en el aparato productivo. 
O artigo 313 apresenta seis diretrizes, as quais trilham o caminho para a efetivação do vivir bien. No entanto, uma transição na esfera econômica prescinde de mudanças em relação às forças produtivas e à lógica de atuação diante da pachamama. Ao prever, via Constituição, a regulação por lei da comercialização, importação e produção de transgênicos ${ }^{162}$, o Estado boliviano dá um recado às transnacionais do setor; demonstra que elas estarão submetidas a regras claras, diferente do que ocorre em boa parte do mundo, as quais não poderão simplesmente ignorar os princípios constitucionais relacionados à "Madre Tierra" e ao vivir bien. Assim, algumas restrições são necessárias aos possíveis efeitos desse tipo de empreendimento, visto que possuem o potencial de afetar a saúde das pessoas, prejudicar o meio ambiente e criar mecanismos de dependência econômica e alimentar.

As condições concretas do Estado boliviano são observadas também ao incorporar diferenciados modelos econômicos, apontando as formas distintas existentes e o combate à desigualdade econômica e social em um dos países mais pobres do mundo. Durante os debates da Assembleia constituinte, as forças políticas acordaram como diretriz, uma perspectiva econômica preponderantemente plural. ${ }^{163}$ A Constituição de 2009 cria condições jurídicas para o desenvolvimento de um modelo econômico alternativo, que ainda não está bem delineado; mas aponta para um novo horizonte, ainda pouco aprofundado, diante da força hegemônica dos atores influentes no campo econômico.

Art. 306. I. El modelo económico boliviano es plural y está orientado a mejorar la calidad de vida y el vivir bien de todas las bolivianas $y$ los bolivianos.

II. La economía plural está constituida por las formas de organización económica comunitaria, estatal, privada y social cooperativa.

\footnotetext{
162 “Artículo 409. La producción, importación y comercialización de transgénicos será regulada por Ley".

${ }^{163}$ ANEXO H - Acordo sobre o Sistema Econômico na Constituição, reconhecendo a economia plural. La Paz, 04 de outubro de 2007.
} 
III. La economía plural articula las diferentes formas de organización económica sobre los principios de complementariedad, reciprocidad, solidaridad, redistribución, igualdad, seguridad jurídica, sustentabilidad, equilibrio, justicia y transparencia. La economía social y comunitaria complementará el interés individual con el vivir bien colectivo.

IV. Las formas de organización económica reconocidas en esta Constitución podrán constituir empresas mixtas.

V. El Estado tiene como máximo valor al ser humano y asegurará el desarrollo mediante la redistribución equitativa de los excedentes económicos en políticas sociales, de salud, educación, cultura, y en la reinversión en desarrollo económico productivo.

A característica plural na economia é a mais importante, a qual representa a metassíntese do novo modelo boliviano. As alternativas ao modelo neoliberal, sobretudo após as lutas populares ocorridas entre 2000 e 2005, as quais atacavam essa política econômica, apareceram no debate da Constituinte. O povo já não aceitava práticas econômicas que Ihes negassem serviços básicos, ou não lhes garantissem emprego; assim, os mecanismos constitucionais de participação dos cidadãos/ãs na dinâmica econômica foram criados, como salienta o artigo 316, ponto $9^{164}$. Havia uma necessidade de se reestruturar um modelo econômico que olhasse para a base social em luta, sobretudo os territórios e comunidades indígenas, e reforçasse o papel do Estado na retomada de setores estratégicos, asseguradores da produção de excedente voltado às políticas públicas.

O indicativo constitucional representa o início de uma mudança de padrão econômico, que não mais aceitaria a ingerência absoluta das transnacionais sem uma contraprestação justa ou a mera extração de recursos naturais, sem quaisquer critérios e direcionados às economias centrais. Definitivamente, a anarquia completa do livre mercado não era mais uma

\footnotetext{
164 “Artículo 316. La función del Estado en la economía consiste en:

( ...)

9. Formular periódicamente, con participación y consulta ciudadana, el plan general de desarrollo, cuya ejecución es obligatoria para todas las formas de organización económica".
} 
alternativa posta na Bolívia. As lutas populares no país indicavam que uma alternativa ao capitalismo era uma necessidade devido ao modo de vida indígena, à busca do vivir bien e a relação sustentável com a natureza. A norma constitucional aponta possibilidades que ampliam o leque de atuação econômica, até porque um comando jurídico não é suficiente para romper com o modo de produção estabelecido.

Assim, a mera eliminação de alguma forma de organização econômica, como a privada, não seria uma saída factível, visto que outras formas não eram desenvolvidas suficientemente. Por outro lado, reconhecer e estimular formas econômicas vivas, apesar de negadas, era uma necessidade. Dessa maneira, além das formas existentes e já previstas como a estatal, social cooperativa e privada, insere-se a forma comunitária. Por isso, a opção por uma perspectiva econômica plural e a complementariedade entre elas possibilita avançar em formas econômicas estratégicas para um projeto político popular na Bolívia.

Todas as formas, com exceção à forma econômica comunitária pura, são regidas em determinada medida por princípios econômicos estabelecidos pelo modo de produção capitalista, mesmo havendo interferência do Estado nessa relação. Contudo, o incentivo ao pluralismo econômico aliado à vontade política de garantir a soberania econômica e a construção igualitária baseada na não exploração do homem/mulher pelo homem/mulher na sociedade, poderá viabilizar ações que caminhem para isso. Mesmo que a hegemonia mundial do capitalismo se faça presente. A Constituição boliviana subsidia o povo e o Estado a criarem alternativas à mera reprodução capitalista dependente que a América Latina está submetida.

Ao especificar as formas de organização econômica, a Constituição chama a atenção para determinadas características de cada uma delas. A organização econômica estatal, por exemplo, terá o papel de traçar as linhas econômicas centrais do país. Um Estado Plurinacional, com projeto popular claro, deverá direcionar suas ações econômicas estatais prezando a garantia dos direitos e serviços fundamentais ao povo, participação e controle social das 
empresas, a industrialização dos recursos naturais e atenção aos impactos ambientais. $\mathrm{O}$ artigo 309 esmiúça essas questões e objetivos.

Já a forma privada, hegemônica na lógica capitalista de produção, é garantida pelo artigo 306 e 308. Como a Constituição prevê, nos próprios dispositivos relacionados à organização econômica do Estado, ela estabelece limitações à acumulação privada e a formação de monopólios, os quais tendem a comprometer ${ }^{165}$ a soberania econômica do Estado. Ademais, a partir do texto constitucional priorizar-se-á, com maiores benefícios, as micro e pequena empresas, geradoras de emprego formal.

A forma comunitária ${ }^{166}$, como salientado, partirá da organização peculiar dos povos e nações indígenas originários campesinas em seus ayllus ou territórios, sendo reconhecida como uma das formas de desenvolvimento econômico na sociedade. Sendo assim, o Estado tem a tarefa de fomentar essas dinâmicas econômicas aprofundando-Ihes a autonomia, a melhora de vida comunitária e dos sujeitos/as que ali vivem.

Si bien hay un reconocimiento de las necesidades materiales (alimentación, vestido, vivienda), la satisfacción humana también implica aspectos 'no materiales' como el respeto, la autodeterminación, la autovaloración, la solidaridad, entre otros, que no pueden existir sólo de manera individual sino relacional, en la búsqueda de una satisfacción común de la colectividad que alberga al individuo, produciendo una dependencia recíproca entre el bien individual con el 'buen vivir' comunitario. (MONTERO, 2010, p. 593-594).

Por fim, a forma social cooperativa também é uma das previsões constitucionais. As cooperativas, apesar de dedicarem-se as mesmas tarefas que os empresários, atendendo aos requisitos como profissionalismo, atividade econômica organizada e produção ou circulação de bens ou serviços, não se submetem ao regime jurídico privado (COELHO, 2013, p. 40). A cooperativa

\footnotetext{
${ }^{165}$ Artigo 313 da Constituição boliviana.

${ }^{166}$ Artigo 307 da Constituição boliviana.
} 
não possui fins lucrativos e cumpre um importante papel social, visto que os trabalhadores/as são os próprios contribuintes e angariadores da produção. A cooperativa social $^{167}$ constitui uma forma solidária de estimulo à produção econômica e desenvolvimento social.

A economia plural apresenta a possibilidade de desmercantilização paulatina das relações sociais existentes no sistema capitalista. Ela seria esvaziada, se não conformada de princípios que a preenche de sentido, como a solidariedade, a reciprocidade, a igualdade, a sustentabilidade, a transparência, a distribuição e a justiça. Nesta seara, a prática da usura financeira e acúmulo desenfreado são passíveis de imediato combate pelos setores do Estado, pois se torna injustificável para esse projeto de nação.

De toda forma, a Bolívia faz uma opção clara nesse momento decisivo e peculiar da história da América Latina. O direcionamento é de saída da ordem estabelecida, configurando novas relações de poder e outra proposta político-econômica. A nacionalização dos hidrocarbonetos ${ }^{168}$ e o combate ao latifúndio ${ }^{169}$ é um desses sinais ${ }^{170}$, são exemplos em que se depara com uma clara demonstração da não aceitação do Estado boliviano à subserviência econômica conservadora e atrasada, prevalecente até então. Elementos que

\footnotetext{
${ }^{167}$ Artigo 310 da Constituição boliviana.

${ }^{168}$ Artigo 359 da Constituição boliviana.

169 "En la Constitución se recuperó el instituto del latifundio, categoría del derecho agrario prevista en la ley $\mathrm{n}^{\circ} 1715$ de 18 de octubre de 1996, del Instituto Nacional de Reforma Agraria, que había quedado en desuso debido a la derogación que operó del procedimiento de afectación. Se señalan cuatro causales bajo las cuales una propiedad agraria es considerada latifundio: a) tenencia de tierras improductivas; b) tenencia de tierras que no cumplen la función económica y social; c) tierras explotadas aplicando un sistema de servidumbre, semiesclavitud o esclavitud en relación laboral (familias indígenas en cautiverio y sujetas a empatronamiento forzoso); y d) tenencia de tierras que sobrepasen la superficie máxima zonificada que será establecida mediante ley. No obstante, los nuevos límites planteados en la Constitución se aplicarán a predios adquiridos con posteridad a la entrada en vigencia de la Constitución, aspecto que originalmente no estaba contemplado y que fue modificado en el Congreso Nacional en octubre de 2008" (SANJíNES, 2012, p. 389-390).
}

170 "Artículo 398 - Se prohíbe el latifundio y la doble titulación por ser contrarios al interés colectivo y al desarrollo del país. Se entiende por latifundio la tenencia improductiva de la tierra; la tierra que no cumpla la función económica social; la explotación de la tierra que aplica un sistema de servidumbre, semiesclavitud o esclavitud en la relación laboral o la propiedad que sobrepasa la superficie máxima zonificada establecida en la ley. La superficie máxima en ningún caso podrá exceder de cinco mil hectáreas." 
apontam um projeto diferenciado do plano, até pouco tempo atrás, neoliberal vigente.

Iván Bascopé Sanjinés esclarece o efeito dos dispositivos relacionados à questão agrária e o cumprimento da função social na Bolívia, os quais interferem, em certa medida, na economia do país;

Se recoge el principio de la reforma agraria de 1953 de que el trabajo es la fuente fundamental para la adquisición y conservación de la propiedad agraria, debiendo las pequeñas propiedades y las comunitarias cumplir con una función social y las empresariales, con una función económica y social. (art. 393 de la Constitución). Esta última se define constitucionalizando los principios de la actual ley $n^{\circ} 3545$ de 28 de noviembre de 2006, de Reconducción Comunitaria de la Reforma Agraria, como empleo sustentable de la tierra, conforme a su capacidad de uso mayor, en beneficio de la sociedad, del interés colectivo y de su propietario. La propiedad está sujeta a revisión periódica para verificar el cumplimiento de la función económica y social, cada dos años. El incumplimiento de este presupuesto conlleva la pérdida del derecho y retorno de las tierras al dominio de Estado sin indemnización. Igual sanción constitucional se impone para la tenencia latifundiaria de la tierra y la doble titulación, por ser contrarias al interés colectivo. La expropiación es el otro mecanismo de desapoderamiento de la tierra a sus titulares, que procede sin excepción por causal de necesidad y utilidad pública, previo pago de una justa indemnización a sus titulares (arts. 399 y 401 de la Constitución). (SANJÍNES, 2012, p. 389)

A nacionalização dos recursos naturais, ou seja, a apropriação estatal dos hidrocarbonetos e minerais possibilitou um maior controle do Estado sobre esses recursos. Devido à importância que possuem, eles são propriedade do povo boliviano, cabendo ao Estado administrar os recursos, produzindo e comercializando-os nos marcos estabelecidos pela Constituição. Uma vez que os hidrocarbonetos são propriedade do povo, esse não poderá ser alienado a outros titulares.

As corporações estatais YPFB - Yacimientos Petroliferos Fiscales Bolivianos - e EBIH - Empresa Boliviana de Industrialización de Hidrocarburos - são instrumentos, previstos na Constituição (artigos 361-363) que permitem a 
operacionalidade desses recursos naturais pelo Estado Boliviano. A YPFB adquiriu a maioria das ações de empresas que realizam operações na Bolívia por meio de decretos supremos, indenizando-as ${ }^{171}$.

La principal actividad a la que se dedican YPFB Chaco y YPFB Andina es la de exploración y extracción de hidrocarburos; YPFB Transporte opera la mayor parte del sistema de ductos de gas natural y líquidos del país, así como la administración de los medios de transporte de hidrocarburos en vehículos especializados; YPFB Refinación tiene a su cargo la administración de las instalaciones de las refinerías más importantes del país, que suponen una capacidad de más del noventa por ciento de procesamiento de hidrocarburos en todo el territorio boliviano: las refinerías Gualberto Villarroel y Guillermo Elder Bell; por su parte YPFB Logística está encargada del almacenaje y distribución de combustibles e hidrocarburos en todo el territorio boliviano; finalmente YPFB Aviación está encargada del suministro de combustibles de aviación (Jet fuely AV GAS), a través de plantas especializadas instaladas en locaciones, como aeropuertos y zonas de abastecimiento. La principal actividad a la que se dedican YPFB Chaco y YPFB Andina es la de exploración y extracción de hidrocarburos; YPFB Transporte opera la mayor parte del sistema de ductos de gas natural y líquidos del país, así como la administración de los medios de transporte de hidrocarburos en vehículos especializados; YPFB Refinación tiene a su cargo la administración de las instalaciones de las refinerías más importantes del país, que suponen una capacidad de más del noventa por ciento de procesamiento de hidrocarburos en todo el territorio boliviano: las refinerías Gualberto Villarroel y Guillermo Elder Bell; por su parte YPFB Logística está encargada del almacenaje y distribución de combustibles e hidrocarburos en todo el territorio boliviano; finalmente YPFB Aviación está encargada del suministro de combustibles de aviación (Jet fuely AV GAS), a través de plantas especializadas instaladas en locaciones, como aeropuertos y zonas de abastecimiento. (CENTRO DE ESTUDIOS CONSTITUCIONALES, 2012).

\footnotetext{
171 "A tiempo de escribir estas notas (enero 2009) el gobierno "nacionalizó" por decreto las acciones de Pan American Energy en la empresa Chaco, disponiendo un pago de 23 millones de dólares por ellas. Se trata de una compra empaquetada, por razones políticas, como una expropiación. No es casual que ello ocurriera en vísperas del referendo constitucional" (ROJAS; PACHECO; TORRICO, 2009, p. 17).
} 
O conjunto de operações cabíveis à YPFB vai da exploração, perfuração, transporte, refino, industrialização e armazenamento do produto. $O$ grande objetivo da industrialização e desenvolvimento dessas Corporações Estatais é possibilitar que se agregue valor à produção boliviana, garantindo maior competitividade no mercado, visto que o país não dependerá somente da extração de bens naturais e minerais, mas também produzirá. Dessa forma, vislumbra-se uma mudança fundamental no papel relegado aos países latinoamericanos na divisão internacional do trabalho como meros exportadores de commodities $^{172}$.

Ademais, a partir do momento que começa a vigência dos Impostos Diretos dos Hidrocarbonetos (IDH) através da lei $n^{\circ} 3.058$, ainda em 2005, há o aumento do preço de exportação do gás natural e do volume de compras, a arrecadação estatal ganha corpo e materializa, em parte, os anseios constitucionais.

Essas são iniciativas constitucionais que tem o condão de começar a alterar as estruturas historicamente dominantes de poder na América Latina.

Diante das questões expostas, observa-se que a busca pela integração dos povos, através da dinâmica constitucional, como mais um elemento potencializador dessa ação, é real. Como já ressaltado, garantir o pluralismo para construção de um Estado e uma sociedade intercultural e popular, destacando um recorte de classe ao projeto político, cumpre um papel fundamental em todo esse processo. Isso permite o avanço de uma nova leitura e estrutura constitucional.

Uma reforma feita na parte orgânica (organização e divisão de poderes) da Constituição gera repercussão na parte dogmática (lista de direitos) e vice-versa (GARGARELLA; COURTIS, 2009, p. 9). Observa-se que a Constituição Política do Estado Plurinacional da Bolívia realiza alterações em ambos os âmbitos e traça condições materiais para a efetivação desse

$\overline{172}$ Artigo 311, parágrafo 3, da Constituição boliviana. 
processo transitório de um Estado Republicano colonial monocultural para um Estado Unitário Social de Direito Plurinacional Comunitário.

As medidas que reestruturam setores da econômica, a partir de uma perspectiva plural e com maior intervenção do Estado, com variados tipos democráticos, com a nacionalização de recursos naturais, com o limite da propriedade agrária, entre outras medidas, configuram mecanismos que possibilitam a alteração do poder, além de indicarem uma mudança de projeto. Os setores estratégicos do Estado e da sociedade mudam, em parte, de mãos e atendem interesses diversos do que atendiam.

Roberto Gargarella coloca um dilema fundamental de ser superado para os países latino-americanos.

Parecemos quedar, entonces, en una encerrona: o tomamos el camino de una reforma mayúscula, a riesgo de cometer graves errores, y aún de impedir lo bueno, buscando lo óptimo; o condenamos la Constitución a convertirse en letra muerta, al poco de nacer. Algunas de las nuevas Constituciones latinoamericanas han intentado, sin embargo, adentrarse en este difícil camino, y procurado actuar sobre las bases materiales de la sociedad, que son aquellas sobre las que la Constitución debe apoyarse (GARGARELLA; COURTIS, 2009, p. 19).

A Bolívia parece ter feito sua opção criando algumas condições materiais concretas para o avanço de um novo projeto de sociedade. 


\title{
CAPÍTULO 3 - PARA UMA NOVA PERSPECTIVA CONSTITUCIONAL NA AMÉRICA LATINA: AS POSSIBILIDADES E OS DESAFIOS A PARTIR DA EXPERIÊNCIA BOLIVIANA
}

\begin{abstract}
"El sistema encuentra su paradigma en la inmutable sociedad de las hormigas. Por eso se lleva mal con la historia de los hombres, por lo mucho que cambia. Y porque en la historia de los hombres cada acto de destrucción encuentra su respuesta, tarde o temprano, en un acto de creación”. (2010, p. 363).

EDUARDO GALEANO. Las venas abiertas de América Latina.
\end{abstract}

A nova Constituição Política do Estado Plurinacional da Bolívia municia o bloco indígena-popular, vitorioso na recente luta política contra as medidas neoliberais, através de normas e estruturas institucionais, em parte, diferente das existentes até então. Inova em alguns aspectos constitucionais e fortalece o papel de determinados sujeitos e grupos sociais antes negados.

A Constituição é um referencial temporal do acúmulo político e social logrado nas lutas empreendidas até a sua promulgação em 2009. A partir de então, no curso da história, o Estado a tem como novo parâmetro político e jurídico, seja na formulação normativa ou na construção de políticas públicas, conforme destaca Oscar Vega Camacho;

Se puede afirmar que hay una nueva cartografía de los derechos en la Constitución no solamente porque se ha ampliado el catálogo de derechos, sino porque hay un rediseño, como un conjunto de capítulos denominado Derechos Fundamentales y Garantías, que introduce una nueva configuración de toda la generación de derechos: humanos, sociales, colectivos y pueblos indígenas. Todos ellos ratificados por las Naciones Unidas, que son por primera vez en su integralidad constitucionalizados y asumidos plenamente por el Estado (2010, p.141). 
Passado alguns anos da entrada em vigência da Constituição, os desafios centrais não desapareceram do horizonte político boliviano, dentre os quais, a manutenção da unidade popular interna e a construção de uma rede de solidariedade latino-americana. Pois, as ingerências imperialistas continuam sendo uma realidade, assim como a tentativa de intervenção política dos grupos de direita, as práticas colonialistas não deixaram de existir, mesmo que estejam mais enfraquecidas, também em decorrência da própria Constituição.

A Bolívia é um país dotado de uma riqueza considerável de recursos naturais e com grande biodiversidade, algo que desperta a cobiça dos Estados imperialistas, para a manutenção da lógica capitalista dependente; além de ser interesse dessas nações, o monopólio sistemático dos setores mais dinâmicos da economia boliviana.

Luis Tapia evidencia isso da seguinte forma:

Uno de los rasgos del imperialismo norteamericano contemporáneo consiste en una geopolítica de control de espacios donde existen recursos naturales estratégicos para la acumulación y el tipo de modelo de civilización y de organización económica capitalista, a través de empresas militares, dictaduras y una subordinación organizada por el sistema financiero (2009a, p. 107).

A manutenção da unidade e o enfrentamento às políticas imperialistas tornam-se concretas, antes de qualquer coisa, através do fortalecimento do Estado. Sobretudo, se esse possui um histórico de debilidade frente às ingerências golpistas e intervencionistas anteriores como seria o caso da Bolívia. Antonio Gramsci aponta alguns requisitos fundamentais para reconhecer o poder de um Estado.

Elementos sobre lo que puede calcularse la jerarquía de poder de los Estados: 1) extensión del territorio, 2) fuerza económica, 
3) fuerza militar, 4) posibilidad de imprimir a su actividad una dirección autónoma, cuya influencia deban sufrir las otras potencias (1981b, p. 223).

Os elementos apresentados são importantes, pois demonstram que o mero fato de eleger um representante popular para o poder executivo ou a maioria do parlamento não é suficiente para ter o domínio do Estado. Outras medidas são fundamentais como: ter um controle social dos meios de comunicação para que não sirvam somente aos grandes grupos econômicos privados, exercer o comando sobre as forças armadas e a distribuição de armas para a população, assim como a reestruturação do sistema de justiça e aparatos burocráticos estatais, entre outros.

Para conquistar todos esses setores, remodelar o Estado e a sociedade, a luta política é fundamental. Isso porque as forças políticas detentoras de poder não cederão suas parcelas, de modo que elas precisam ser conquistadas. A Constituição é uma ferramenta central para direcionar essas mudanças. Os grupos organizados e as circunstâncias históricas são fatores que permitirão o êxito de um projeto distinto do status quo, pois possibilitarão uma ação direcionada das massas (LEONEL JÚNIOR, 2014a, p. 101).

No contexto latino-americano desse início de século XXI delineiam-se três projetos em disputa, sendo que a Bolívia desponta em um deles. $O$ primeiro, facilmente identificável, é sustentado pelas forças e eventuais governos de direita, os quais incorporam a pauta imperialista. $O$ segundo, exemplificado por países como o Brasil e a Argentina ${ }^{173}$, tem como característica uma política neodesenvolvimentista e fortalece, em determinada medida, as relações externas entre os Estados do sul sem enfrentar diretamente as políticas imperialistas. Já o terceiro projeto, em que a Bolívia é um dos componentes, caracteriza-se por resistir às práticas neoliberais e imperialistas e contribui para ações que integrem os Estados da América Latina a partir da ideia de "Pátria Grande" ilustrada pela construção da ALBA -

\footnotetext{
${ }^{173}$ Após as eleições presidenciais de Lula/Dilma e de Nestor/Cristina Kirchner.
} 
Aliança Bolivariana para os Povos de Nossa América - e indo além da temática meramente econômica.

$\mathrm{Na}$ Bolívia, os grupos sociais populares identificaram o inimigo maior e as suas ações impactantes. No caso concreto eram as políticas neoliberais, influenciadas pelo imperialismo, puxadas pelo bloco histórico da elite econômica. Diante do desafio as forças populares lograram triunfar sobre eles. Contudo, não é um triunfo definitivo e completo; ele só poderá ser completo, caso o projeto político popular alastre pelos outros Estados latino-americanos e consolide um modelo emancipatório.

Ao trazer para a América Latina táticas políticas próprias para enfrentar ações imperialistas que passam pela própria formatação constitucional, cabe destacar que elas devem compreender aspectos para além da categoria clássica de imperialismo ou desenvolvimento desigual, como destacado ao longo do trabalho. Mas, deve atentar-se também para o enfrentamento à construção histórica colonial e as emergências civilizatórias recentes, como o adequado tratamento da relação homem/mulher-natureza ${ }^{174}$.

Até o alcance de objetivos emancipatórios, inúmeras controvérsias internas permearão o processo político do bloco histórico vitorioso na Bolívia, porém, elas não devem ser tratadas como centrais, pois não há um confronto de projetos nacionais de poder por meio de grupos antagônicos. Existe, nesse sentido, um projeto nacional em curso e tensões regionais ou locais a respeito de determinadas temáticas; assim, os dirigentes atuais se deparam com situações complexas como, por exemplo, investir no desenvolvimento econômico e social nacional em benefício de todo povo ou nas autonomias indígenas, garantindo direitos de povos específicos; se devem fortalecer os diversos mecanismos de democracia participativa de imediato ou manter temas

\footnotetext{
174 "Por lo tanto, la configuración del Estado plurinacional supone otra teoría crítica del capitalismo, ya no se trata solo de visualizar un desarrollo desigual y combinado, ni tan solo quedarse en la tesis del imperialismo como fase superior del capitalismo. (...) en lo que respecta a la compresión del Estado plurinacional se requiere entender los ciclos del colonialismo, sus transformaciones, la estructura de sus crisis, además de sus es-trechos vínculos con el capitalismo y la modernidad. Es indispensable comprender la crisis civilizatoria y los alcances de la crisis ecológica" (PRADA, 2012, p.407).
} 
centrais nas mãos da, até então, classe dirigente. Aparecem esses, dentre outros tantos debates que surgem a todo 0 momento de acordo com 0 andamento do processo político e social.

O momento histórico boliviano traz essas tensões, que Álvaro Garcia Linera descreverá como secundárias e não antagônicas ao interior do "bloco popular revolucionário" (2012a, p.27), inerentes à própria dialética necessária para o avanço do processo. Analisá-las poderá ajudar na compreensão das mudanças sociais decorrentes das transformações do Estado, possibilitadas pela nova conformação constitucional. Ou seja, esse é um momento de verificações pós-constitucionais e não mais apreciações dos seus dispositivos. Trata-se de caminhar da teoria ao concreto.

Nesse momento objetiva-se analisar, não de maneira exaustiva, alguns pontos nevrálgicos de temáticas centrais, que foram materializados e modificados com o advento da Constituição no propósito de construção real do Estado Plurinacional.

\subsection{A consolidação revolucionária para a refundação do Estado boliviano desde a descolonização e a plurinacionalidade.}

Um dos pontos fundamentais para observar as transformações advindas com a Constituição de 2009 é a respeito do que alguns autores tratam como a refundação do Estado. No caso boliviano, analisar esse elemento requer atentar-se também para as características intrínsecas a ela, como a descolonização e a plurinacionalidade.

Certamente, a mera promulgação de uma nova Constituição não garante a refundação de um Estado, pois alguns pilares e um projeto político diferenciado precisam ser viabilizados concretamente. Boaventura de Sousa 
Santos chama a atenção para essa tarefa contraditória de tentar transformar completamente alguma coisa para manter sua existência, no caso, o Estado.

Nesse sentido, ele afirma:

(...) no es fácil transformar radicalmente una institución que, en su forma moderna, tiene más de trescientos años. Además, ¿cómo se puede transformar radicalmente una entidad cuando el objetivo último es, de hecho, mantenerla? Refundar el Estado no significa eliminarlo; al contrario, presupone reconocer en él capacidades de ingeniería social que justifican la tarea política de refundación. (2010, p. 74)

Inicia-se a construção de um Estado Plurinacional na América Latina com a sanha descolonizadora que caminha no propósito refundador; alguns militantes políticos e o próprio governo denominam o processo boliviano como um processo revolucionário (BAJO; ARKONADA, 2012). De fato, se a utilização do termo for condizente com a leitura que faz o pesquisador Raphael Seabra, no sentido de considerá-lo um "fenômeno de transformação social, político e econômico de longa duração e não necessariamente insurrecional, quer dizer violento" (2012, p. 30), podemos dizer que a Bolívia vive um processo revolucionário.

Nesse sentido, caberia com isso verificar;

[...] o desenvolvimento e coexistência dos modos de produção existentes, assim como a análise de sua estrutura de classes. [...] Pois, a partir da determinação da natureza da sociedade, da estrutura e relação entre as classes é que se definem quais são os objetivos da revolução, ou seja, as tarefas a cumprir; quais são os inimigos que se vão enfrentar; e, finalmente, as forças motrizes, as classes revolucionárias que vão realizá-la e seus aliados entre outras classes e setores de classes. [...]. Em última instancia e em definitivo, seu caráter é dado pela classe que detiver hegemonicamente o poder (BAMBIRRA apud SEABRA, 2012, p. 35-36). 
Cada Revolução é única, pois parte das condições materiais apresentadas no processo de luta posto. No caso da Bolívia, verificamos a coexistência de distintos modos de produção (sistema comunal e o sistema capitalista) e o protagonismo do bloco indígena-popular no comando da dinâmica transformadora do país.

Nesse propósito de refundação do Estado, para Garcia Linera (BAJO; ARKONADA, 2012) a Revolução Política e Descolonizadora segue seu curso, enquanto resta aprofundar a Revolução Econômica pós-capitalista na Bolívia $^{175}$. Uma revolução, que não seja de curta duração, terá períodos de maior e outros de menor radicalidade, de acordo com seu desenvolvimento e ritmo peculiar. Para o diretor geral do Ministério da Cultura da Bolívia, o aymara Idón Chivi Vargas (2013), o que ocorre na vida política boliviana é um processo revolucionário, pois se mexe nas bases econômicas, se trabalha o conceito de propriedade social e há uma narrativa política que caminha nesse sentido para a transformação das bases objetivas e subjetivas da sociedade. Contudo, um processo que está iniciando e de forma alguma está pronto. Já Jorge Viaña (2013), professor de economia e responsável pelo Centro de Pesquisas políticas e sociais da Vice-presidência da Bolívia, observa o processo boliviano como uma parcial revolução política, onde houve a substituição de um setor de classes por outro, porém sem a eliminação completa das estruturas existentes do Estado. Para Oscar Vega Camacho (2013), integrante do grupo Comuna, a ideia de descolonização muda, inclusive a forma de se enxergar o conceito de revolução. Para ele, não somente uma vanguarda teria condição de romper com o status quo, nem a política seria feita somente pelos partidos. Os processos políticos poderão ocorrer de outra forma, a partir dos grupos e coletivos.

Alguns sinais devem ser expostos para demonstrar se, de fato, os mecanismos trazidos com a nova Constituição foram suficientes para garantir um processo revolucionário na Bolívia. Importante destacar que, uma vez que

\footnotetext{
${ }^{175}$ Não se trata da materialização de um processo revolucionário de cunho socialista no país nesse momento. A ascensão do projeto transformador boliviano culminou, na reconfiguração do cenário político e da correlação de forças entre os grupos e organizações sociais do Estado. Contudo, o modo de produção não foi alterado substancialmente na Bolívia.
} 
não foram cumpridas historicamente as promessas da modernidade e, consequentemente, as tarefas democráticas, nacionais e populares, elas se tornam bandeiras da luta revolucionária. Isso permitiu o contato das massas com as pautas da luta política e consequente conscientização das mesmas, trazendo um nível de radicalidade em suas ações, as quais não possibilitaram a sua absorção pela ordem e por grupos sociais ligados à elite econômica.

Alguns compromissos são fundamentais para o sucesso de um projeto popular, e no caso boliviano para sedimentar com isso a luta revolucionária, conforme destaca Benjamin, sobretudo ao levarmos esses pontos a uma análise dos países latino-americanos.

(a) O compromisso com a soberania. Ele representa a nossa determinação de dar continuidade ao processo de construção nacional, rompendo com a dependência externa e dando [...] autonomia decisória.

(b) O compromisso com a solidariedade. Ele diz que a continuidade da construção nacional deve se dar em novas bases, tendo em vista a tarefa de edificar uma nação de cidadãos. A reorganização das instituições e do esforço produtivo da sociedade deve ter como prioridade eliminar a exclusão social e a chocante desigualdade na distribuição da riqueza, da renda, do poder e da cultura.

(c) O compromisso com o desenvolvimento. Ele expressa a decisão de pôr fim à tirania do capital financeiro e à nossa condição de economia periférica, dizendo que mobilizaremos todos os nossos recursos produtivos e não aceitaremos mais a imposição de políticas que frustrem o nosso potencial.

(d) O compromisso com a sustentabilidade. Ele estabelece uma aliança com as gerações futuras, pois se refere à necessidade de buscarmos um novo estilo de desenvolvimento, que não se baseie na cópia de modelos socialmente injustos e ecologicamente inviáveis.

(e) O compromisso com a democracia popular. Ele aponta para a refundação do sistema político [...] em novas bases, amplamente participativas, de modo que a sociedade possa efetivamente controlar os centros de decisão e poder. (2000, p. 20).

As tarefas elencadas aqui por César Benjamin são pensadas a partir da busca de unidade e cumprimento de todos esses pontos. Esses pontos remetem a uma análise da realidade brasileira, mas certamente também cabível à estrutura social boliviana. Por isso, o projeto popular é passível de 
implementação nos países latino-americanos, os quais sofrem com problemas estruturais em sua formação e reprodução colonial, capitalista e eurocêntrica do poder. Dessa forma, a implementação de um projeto popular tende a ser um caminho para o aprofundamento do processo revolucionário.

As mudanças mais significativas, anteriores à atual Constituição boliviana, tinham o caráter de evidenciar a multietnicidade e a pluriculturalidade formadora do país. Essas reformas ocorridas no ano de 1994, reconhecedoras de personalidades jurídicas de comunidades indígenas entre outras ações afirmativas, mantinham seu núcleo forte no domínio econômico e crescente implantação do neoliberalismo. Este, por si só, constituía um aparato limitador estrutural de qualquer política emancipatória, mesmo que concorressem políticas paliativas garantidoras de pluralidade. Dessa forma, a Bolívia mantinha, historicamente, um conjunto de instituições do Estado definidos a partir de uma cultura dominante estabelecida (TAPIA, 2007b).

$\mathrm{Na}$ atual dinâmica boliviana, o discurso político que permeou todo processo constitucional foi o de "refundação" do Estado. Uma vez que tal discurso afirma a intenção de construir coletivamente um Estado Unitário Social de Direito Plurinacional Comunitário, e não mais sustentar o Estado anterior que se assentava em um passado, descrito no próprio preâmbulo constitucional, "colonial, republicano e neoliberal". Mesmo que haja uma exposição textual afirmando essa assertiva progressista, as condições políticas, econômicas e sociais devem estar postas para alavancar estas transformações.

A primeira dimensão modificada é a simbólica, ao constatar-se um bloco indígena-popular no poder e um chefe de Estado indígena; essa experiência eleva a auto-estima do povo, pois permite que as várias nações e povos bolivianos acreditem na própria competência em governar um Estado para todos/as, formado inclusive com outras etnias não indígenas ${ }^{176}$. A colonialidade do poder, historicamente construída, fragiliza-se por meio desse

\footnotetext{
${ }^{176}$ ANEXO I - Distribuição departamental da população de acordo com a sua condição étnicolinguística.
} 
cenário político. Isso, pedagogicamente, estimula esses povos a lutarem, cada vez mais, por espaços e direitos, uma vez que vivenciaram toda uma história de negação desses espaços e desses direitos.

3.1.1. As ações da descolonização cultural e da despatriarcalização.

A descolonização cultural conforma-se por dois eixos complementares. Um referir-se-á "à diversidade de culturas, de idiomas, de histórias e memórias. E o outro eixo referido à diversidade de civilizações, isto é, de modos de produção do sentido da vida, do tempo e da politica" (tradução livre) (GARCIA LINERA, 2010a, p. 31). Há um reconhecimento, além de ações voltadas a essa reconstrução cultural descolonizadora, valorizando outros saberes, discursos, conhecimentos que não os convencionais modernos/ocidentais.

La escuela y la universidad van a enseñar obligatoriamente en tres idiomas: castellano - como idioma de integración -, una lengua extranjera - como idioma de comunicación con mundo - y un idioma indígena dominante en la región: aymara en la Paz, quechua en Cochabamba y guaraní en Santa Cruz. (...) En el área de salud ya se han dado pasos más grandes, por ejemplo colocando junto al médico al "naturista", o al lado de la enfermera a la partera, y la gente puede optar en el centro médico (GARCIA LINERA, 2010a, p. 32).

Essas ações demonstram uma postura da atual classe dirigente boliviana, no sentido de avançar no processo descolonizador do país. Certamente, o grupo fundamental para a construção teórica e o direcionamento prático da descolonização são os indígenas originários campesinos. Desde o aspecto normativo, no final de 2008, é aprovado o Plano Nacional de Ação de Direitos Humanos (Decreto Supremo $n^{\circ} 29.851$ ) e o Plano Nacional de 
Igualdade de Oportunidades (Decreto Supremo n 29.850). Ambos recuperam a descolonização e a despatriarcalização como aspectos centrais dos direitos humanos e de gênero ${ }^{177}$.

O Vice-Ministério da Descolonização e a Unidade de Despatriarcalização possuem um papel importante para o combate à opressão na Bolívia. Esse mal atinge toda a população, inclusive as nações indígenas que absorvem os conceitos patriarcais e os reproduzem em certa medida.

O depoimento de Lucila Choque Huarin exemplifica essa questão:

Un Mallku, me dijo un día, la mujer originaria, es como «un animalito que sirve solo para el sexo, las wawas y la cocina por eso no saben nada y por eso es difícil que participen». Me pareció no creer que su propio comunario pensase así de la mujer, sin embargo, había otro Mallku que me decía "sin las mujeres nada sería la comunidad". Encontramos así en la subjetividad de los propios comunarios de pueblos indígena originario campesinos un parecido en la visión que tiene de la mujer moderna (2012, p. 82).

Alguns programas foram implementados nesse propósito descolonizador e despatriarcal como o "Matrimonios colectivos desde nuestra identidad". Através desse programa, vários casais unem-se em um ritual que respeitam os costumes ancestrais a partir do equilíbrio do ser humano, ou seja, para garantir uma construção sem atitudes machistas ou patriarcais, com igualdade de gênero e divisão de responsabilidades. O modelo familiar concebido não é subserviente à nenhuma instituição religiosa e tem uma base plurinacional.

\footnotetext{
177 Além desses, existem outros projetos que seguem o mesmo sentido descolonizador e despatriarcalizador como: o desenvolvimento da primeira carreira em Descolonização e Gestão Pública; o anteprojeto de lei de Equivalência constitucional, o qual prevê que o sistema de designação de cargos hierárquicos de decisão política nas diversas esferas do Estado devem se dar de modo paritário, com participação $50 \%$ de homens e $50 \%$ de mulheres, além de garantir representação plurinacional; projeto de descolonização do Código Penal Plurinacional, o qual prevê delitos relativos às violações à Pachamama, às violações aos direitos coletivos indígenas, entre outros.
} 
A seguinte tabela apresenta dados sobre o número de contraentes em 2011:

\begin{tabular}{|l|l|}
\hline \multicolumn{1}{|c|}{ DEPARTAMENTO } & \multicolumn{1}{c|}{$\begin{array}{c}\text { CANTIDAD } \\
\text { CONTRAYENTES }\end{array}$} \\
\hline La Paz & 154 \\
\hline Oruro & 165 \\
\hline Potosi & 31 \\
\hline TOTAL & 350 \\
\hline
\end{tabular}

Tabela 06 - Quantidade de contraentes do programa "Matrimonios colectivos desde nuestra identidad".

Fonte: (BOLIVIA, 2012, p. 38).

Mesmo com essas ações, os ayllus ainda detêm práticas sexistas, em que as mulheres exercem funções de segundo plano, enquanto os homens assumem uma posição de maior destaque ${ }^{178}$. Por mais que se busque promover o equilíbrio através da composição aymara Chacha-Warmi (homemmulher) nesse tipo de comunidade. Mesmo na dinâmica da vida urbana, as mulheres dificilmente chegam a assumir, por exemplo, a presidência de uma junta de vizinhos ou a direção gremial, porque são responsáveis pelos serviços familiares (PUENTE; LONGA, 2007, p. 103).

Outra medida despatriarcalizadora está relacionada ao novo código de famílias, aprovado pelo Senado, dia 16 de outubro de $2014^{179}$, o qual rompe com o modelo de família formado por homem, mulher e filhos/as, e prevê outros tipos de família, fundados em uma perspectiva eudemonista e afetuosa, independente se parte de uma relação hetero ou homoafetiva. A base constitucional atual abarca todas essas possibilidades, garantindo segurança jurídica a essas concepções.

\footnotetext{
178 “(...) la mama t'alla (autoridad femenina de la comunidad) acompaña al esposo adonde sea y debe sustituirlo en caso de ausencia, pero nunca puede reemplazarlo ni decidir por él." (TICONA, 2003, p. 131).

179 O código entrará em plena vigência em 2015.
} 
As ações do Estado Plurinacional surgem no sentido de garantir um maior respeito aos homens e às mulheres que compõem as nações e povos bolivianos. Não por acaso, esse respeito se dá também no reconhecimento das cerimônias tradicionais e rituais ${ }^{180}$, como a celebração do solstício de inverno, no dia 21 de junho, ano novo andino, amazônico e no chaco, valorizando a cosmovisão e a espiritualidade dos povos.

É necessário realizar o direcionamento de políticas públicas descolonizadoras, conforme destaca o professor de direito constitucional da Universidade Católica boliviana, Farit Rojas, (2013). A reprodução das estruturas colonizadoras provenientes de práticas históricas dominadoras deve ser desconstruída, sobretudo, em seu aspecto educacional e político.

3.1.2. A plurinacionalidade como opção política real em variados setores.

O caráter político da revolução evidencia-se na constituição de elementos que direcionaram para um ambiente de mudanças nas estruturas de poder da Bolívia, da composição das classes sociais dirigentes do Estado, e na natureza social da institucionalidade estatal. Logo, configura-se uma arquitetônica política diferente da que vigia antes dos anos 2000, quando as decisões de governo estavam submetidas à vigilância da Embaixada dos Estados Unidos e as ações do Ministério da Fazenda subservientes ao crivo do FMI - Fundo Monetário Internacional - e do Banco Mundial (BAJO; ARKONADA, 2012).

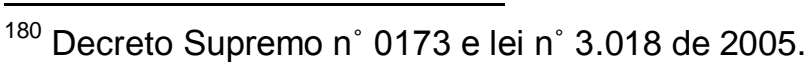


A constituição da plurinacionalidade possui caráter essencial para sedimentar essa revolução política, visto que a partir da constitucionalização do conceito amparou as formas educacionais, jurídicas, culturais, o reconhecimento de autoridades dos diversos povos e nações indígenas. Esses pressupostos amparam ações decorrentes do Plano Nacional de Desenvolvimento (BOLIVIA, 2007) nos variados âmbitos da sociedade.

No aspecto educacional, as mudanças tomam corpo, sobretudo após a promulgação da Lei Avelino Siñani - Elizardo Pérez, como já destacado no capítulo anterior. Inicia-se uma transformação no sistema educativo que tornouse plurinacional, intercultural e plurilíngue. A base curricular escolar leva em conta a produção dos saberes, conhecimentos e tecnologias das nações e povos indígenas originários. Isso contribui para a formação de professores que reproduzirão esse desenho curricular a partir das Escolas Superiores de Formação de Professores/as (ESFM ${ }^{181}$ ). Além da formação, o Estado estimula os alunos/as a permanecerem na escola através do "Bono Juancito Pinto", que em 2011 beneficiou 1.688.268 crianças no país (BOLIVIA, 2012, p. 5).

Além dessa mudança no sistema educacional plurinacional, seguindo os mandamentos constitucionais do artigo 93 da Constituição boliviana, e por meio do Decreto Supremo $\mathrm{n}^{\circ} 29.664$, foram criadas universidades indígenas voltadas prioritariamente para esses povos.

- Universidade Apiaguaiki Tupa, localizada no município de Machareti, comunidade Ibo, no departamento de Chuquisaca, município com importante população guarani.

- Universidad Tupak Katari (aymara), localizada em Warisata, departamento La Paz.

- Casimiro Huanca (quechua), localizada no município de Chimoré no departamento de Cochabamba ${ }^{182}$. (BOLIVIA, 2012, p.5)

\footnotetext{
${ }^{181}$ A sigla está em castelhano e significa "Escuelas Superiores de Formación de Maestros".

182 "Actualmente en las mencionadas universidades se desarrollan 12 carreras relacionadas a la productividad y desarrollo comunitario: agronomía altiplánica, industria textil, zootecnia y veterinaria e industria de alimentos, agronomía Tropical, Forestal, Industria Textil, pisicultura, veterinaria, hidrocarburos, forestal y piscicultura. Se ha beneficiado a 1.495 jóvenes
} 
Aliado às mudanças educacionais, observa-se o avanço do marco legal no combate ao racismo. Por meio da lei $n^{\circ} 045$ de 2010 e do decreto regulamentar $n^{\circ} 762$ de 2011 foi formado o Comitê Nacional contra o Racismo e toda a forma de Discriminação que elaborou um diagnóstico, o qual resultou em um Plano de ação do Estado Plurinacional contra o racismo.

Algumas ações que afirmam a plurinacionalidade também possuem um papel tático muito interessante, como o fortalecimento da rede de comunicação nas comunidades através das rádios comunitárias das nações e povos originários, além do implemento de telecentros comunitários ${ }^{183}$. Essa é uma forma de garantir a liberdade de expressão e a democratização da comunicação, sobretudo nas áreas rurais e de interesse social.

Outro setor estratégico em que a atuação do Estado Plurinacional contribui para o caráter descolonizador e popular da instituição são as Forças Armadas. A firmeza e fidelidade desse setor, junto ao governo central, para a consolidação do projeto plurinacional-popular no período de choque entre os blocos históricos antagônicos em 2008, não ocorreu por acaso.

O governo de Evo Morales definiu um plano estratégico a respeito do papel das forças armadas na democracia boliviana. Após 1982, as Forças Armadas foram abandonadas diante das políticas neoliberais voltadas aos mercados internacionais, sendo seus comandantes manipulados pela elite que governava o país (GARCIA LINERA, 2010b, p. 22). A retomada da presença estatal nos setores institucionais para assegurar a reconstrução soberana e cidadã da Bolívia impulsionou a valorização das Forças Armadas e sua base

estudiantes de pueblos indígenas. En la gestión 2011, el Tesoro General de la Nación (TGN) desembolsó Bs 45,3 millones destinados a las universidades indígenas bolivianas comunitarias interculturales productivas -UNIBOL "Aymara", "Quechua" y "Guaraní y Pueblos de Tierras Bajas" en cumplimiento al Decreto Supremo N² 29664 de 02 de agosto de 2008" (BOLIVIA, 2012, p.5).

183 Esses avanços são garantidos via Ministério das Comunicações através do "Programa Nacional de Telecomunicações de Inclusão Social" (PRONTIS). 
militar, composta majoritariamente por indígenas/trabalhadores/camponeses, os quais se viam representados após 2005.

No Estado Plurinacional, além de garantir o controle das fronteiras e expansão territorial da presença estatal através de seu aparato coercitivo, que antes estava nas mãos de caciques e máfias locais e regionais (GARCIA LINERA, 2010b, p. 23), as Forças Armadas garantem a execução dos programas sociais sendo os responsáveis pelos pagamentos realizados às famílias. Tanto dos benefícios Juancito Pinto, quanto Juana Azurduy de

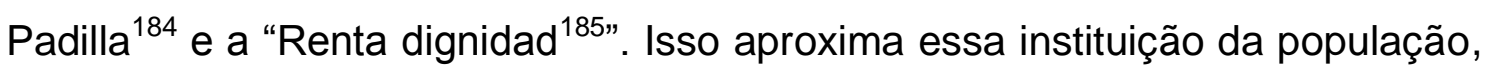
concebendo laços mais democráticos e populares no cotidiano das Forças Armadas.

Ademais, o governo institucionalizou uma instância denominada ViceMinistério de Coordenação com Movimentos Sociais. A atuação do ViceMinistério se dá a partir do monitoramento oportuno e eficaz dos conflitos sociopolíticos, acordos, convênios realizados entre os movimentos sociais e as instâncias governamentais dinamizando essas ações junto à gestão pública (BOLIVIA, 2012, p. 35).

A intenção em construir esse Vice-Ministério parte da relação histórica delicada entre Estado e Movimentos Sociais. O Estado, como entidade administrativa centralizadora de decisões, frente à dinâmica democratizante e deliberativa dos movimentos sociais. Essa é uma das tensões criativas referidas por Álvaro Garcia Linera que bota de um lado a concentração frente à descentralização de decisões, o tempo curto para obter resultados frente 0 tempo largo para as deliberações sociais (2012a, p. 29). No entanto, o avanço de um Estado integral que expande suas funções por toda a sociedade, acarreta o risco de retirar a autonomia dos movimentos e sindicatos. Essa tensão criativa e necessária permanecerá por algum tempo, na busca de aprofundamento de uma dinâmica de ruptura, já que o processo de expansão democrática do Estado deve continuar aliado à preservação das estruturas

\footnotetext{
${ }^{184}$ Auxílio dado para evitar a mortalidade infantil e materna.

${ }^{185}$ Auxílio dado aos idosos para a garantia de um envelhecer digno.
} 
sindicais dos ayllus e comunidades autônomas, por exemplo (GARCIA LINERA, 2012a, p. 35).

Essas contradições fazem, inclusive, que os movimentos sociais mais representativos posicionem-se de formas distintas em relação às políticas do governo ou do direcionamento do próprio bloco histórico. Em entrevista com Damián Condori, secretário executivo da CSUTCB e com Félix Becerra, Jiliri Apu Mallku ou autoridade máxima da CONAMAQ, nota-se isso.

Para Damián Condori, (2013) desde a promulgação da Constituição ingressa-se em um processo transformador de curto, médio e longo prazo. 0 início apresenta algumas dificuldades, mas a tendência é aprofundar as mudanças. A base dessas mudanças já está nas práticas descolonizadoras, destaca o dirigente da CSUTCB.

Já Félix Becerra (2013) entende que dependerá da aplicação constitucional plurinacional para que se possa falar de algum processo revolucionário que acumule forças para os povos indígenas. Para ele, ainda falta ao Estado cumprir os direitos indígenas. Há uma manutenção de investimentos em setores ligados aos empreendimentos transnacionais e ainda há pouco incentivo aos grupos que movimentam a economia indígena.

As controvérsias intrabloco, a que se refere Garcia Linera e evidenciada pela fala dos dirigentes de movimentos sociais, são fruto da reestruturação do Estado sob o crivo de uma nova vertente hegemônica. Os efeitos decorrentes dessas tensões tendem a moldar o agir da nova potestas boliviana.

De fato, delineia-se o início de um novo tempo na Bolívia, fruto da luta política travada em período recente. Contudo, o produto dessas lutas não está composto somente por pautas vitoriosas desse bloco revolucionário: as limitações diante da correlação de força social estiveram presentes para o alcance de algumas vitórias, inclusive para a aprovação do referendo constitucional, conforme já salientado. Assim, a própria Constituição Política do Estado Boliviano resulta dessa batalha, a qual hegemonicamente prevalecem 
propostas transformadoras, desde um ponto de vista sociopolítico, embora o bloco elitista-reacionário tenha deixado várias marcas.

Boaventura de Sousa Santos aponta alguns limites constitucionais significativos no seu ponto de vista, os quais inviabilizaram mudanças mais profundas.

(...) no se define el número de circunscripciones especiales indígenas en la Asamblea Legislativa Plurinacional, reduciéndose luego a solamente siete en la Ley Electoral Transitoria; se impide la reforma agraria al determinar la noretroactividad de la ley sobre el tamaño máximo de la propiedad de la tierra; se restringe la justicia comunitaria indígena, confinándola a indígenas en sus territorios y entre sí; se altera la composición del Tribunal Constitucional Plurinacional que pasa a exigir como requisito para todos sus miembros la formación jurídica académica eurocéntrica, y apenas algunos de ellos deben tener conocimiento de los derechos indígenas. (2010, p. 81)

Logo, o fato da Constituição boliviana de 2009, resultar da negociação entre os grupos antagônicos para que fosse promulgada, após intensos conflitos políticos e sociais, conforme já destacado, impõe esses limites ${ }^{186}$. Além disso, nem toda a herança histórica é negada ao promulgar uma Constituição. Nota-se a permanência de elementos de uma estrutura constitucional, ainda liberal, que persiste ${ }^{187}$ em certa medida. É algo latente,

\footnotetext{
186 “(...) proceso y del pacto político que permitió salvarlo, se introdujo una serie de limitaciones inconsistentes con el modelo de pluralismo igualitario, lo que generó. disputas legales y políticas. Entre las limitaciones que inconsistentemente se introdujeron en el texto boliviano final, cabe mencionar:
}

- La autonomía indígena fue reducida por debajo de los límites departamentales, de modo inconsistente con el principio de la libre determinación de los pueblos.

- Se introdujo una cláusula para la restricción del ejercicio de la jurisdicción indígena desde una mentalidad colonial que impone limitaciones a la competencia territorial, personal y material, de modo inconsistente con el principio de la igualdad de jurisdicciones y el derecho a la libre determinación de los pueblos indígenas que el mismo texto consagra." (FAJARDO, 2011, p. 153).

187 “(...) a recuperación de la teoría clásica de los procesos constituyentes y de la verdadera naturaleza originaria y creadora del poder constituyente ha incidido en la forma y estructura de las nuevas constituciones latinoamericanas que, sin romper con el concepto racional normativo 
não só na construção da Constituição em si, mas, na própria ontologia do direito.

Há quem faça uma leitura desse processo tratando-o como construtor de um liberalismo constitucional atenuado.

[...] o argumento aqui defendido é de que existe uma proposta que chamo de liberal constitucional atenuada que vem sendo posta em prática no subcontinente através do processo de incorporação dos direitos coletivos dos povos originários e afrodescendentes e do reconhecimento amplo de sua condição enquanto grupos historicamente subjugados. [...]. Pois princípios-chave do liberalismo constitucional implementado na América Latina persistem e são reafirmados na nova Constituição - como a existência de uma visão abstrata e universal de indivíduos, a proclamação de direitos naturais inalienáveis, a divisão dos poderes que visa assegurar a proteção a esses direitos e o controle das instituições estatais, a representação política, a hierarquia e a impermeabilidade de algumas esferas como o exército, a economia e, em menor medida, o sistema judiciário (MOTA, 2009, p. 134-135).

De fato, a reprodução das características apresentadas aponta que as mudanças constitucionais mantêm aspectos liberais claros. De acordo com a autora citada acima, aparentemente um Estado Unitário Social de Direito Plurinacional Comunitário, tal qual manifestado na Constituição, compatibilizase, em determinadas medidas, com uma estrutura organizativa liberal.

A propriedade privada ainda é o grande bastião do Estado. As inovações tratam de uma reestruturação e diversificação do direito de propriedade na nova Constituição, mas ainda sustentando-o ${ }^{188}$. Não está colocada a possibilidade de socialização dos meios de produção ou algo nesse

de constitución - texto escrito, ordenado y articulado -, sí se adentran en algunas especificidades que, en buena medida, recuperan varias de las preocupaciones - e, incluso algunas soluciones - del constitucionalismo liberal revolucionario.(...)". (MARTíNEZ DALMAU; VICIANO PASTOR, 2010a, p. 12).

${ }^{188}$ A propriedade coletiva é prevista juntamente com a individual no artigo 56 , onde se enfatiza ainda a sua função social. 
sentido. Há uma maior intervenção do Estado como representante da vontade do povo boliviano.

Algo constatável é que esses elementos liberais, não impedem a continuidade do processo de ruptura estabelecido na Bolívia. Não estão "inventando a roda" ou uma forma constitucional sui generis de qualquer outro modelo, mas refundando novos pilares constitucionais e do próprio Estado, compreendendo que suas estruturas já partem de alguns pilares. É a tentativa de reapropriação pela classe trabalhadora e excluída, de estruturas ontologicamente liberais caminhando para um sentido transontológico, ou seja, reconstruindo essas instituições, mesmo sem ignorar que elas ainda ocorrem assentadas em um modo de produção capitalista.

Certamente, as limitações concretas estão presentes, além de ações que podem ser consideradas um avanço para aqueles que lutam por uma América Latina descolonizada, intercultural e anticapitalista. Estas são demonstradas sob diversas formas, onde observar-se-á contradições e empecilhos às transformações. A Constituição boliviana de 2009 não é diferente.

O Estado Plurinacional da Bolívia, amparado pela Nova Constituição Política, toma medidas que atacam opressões históricas na América Latina. Ainda são poucos anos de desconstrução da histórica estrutura colonial, mas a Revolução descolonizadora nos marcos do Estado Plurinacional abre as portas para um projeto civilizatório distinto.

Abre-se a possibilidade de atacar e, em longo prazo, eliminar as dimensões dominadoras que Enrique Dussel (2011) se refere, como no âmbito erótico, ao ser rechaçado o machismo e concebido políticas públicas para equidade de gênero em todos os âmbitos. Também há uma mudança de postura na dimensão pedagógica, onde há uma valorização da própria cultura e educação com reprodução de valores, os quais tentam não reportar às opressões. Por fim, deve se destacar a dimensão política reestruturada a partir de novos sujeitos compostos pela classe trabalhadora, indígenas comunais, 
campesinos/as, ou seja, o povo historicamente oprimido e excluído que toma as rédeas do aparato estatal.

\subsection{A economia e o vivir bien em tempos de Estado Plurinacional.}

3.2.1. A dura tarefa da modificação da estrutura econômica ao longo do processo transformador.

A Constituição Política do Estado Plurinacional da Bolívia trata de reconhecer e estimular a diversificada dinâmica econômica do país atrelando-o ao alcance ideal do vivir bien, ainda dentro dos marcos do capitalismo.

Antes dessa análise, cabe chamar a atenção para o contexto econômico da América Latina a partir da dependência a qual está submetida. A integração à lógica econômica do sistema-mundo ocorreu desde uma economia primário-exportadora dos países latino-americanos.

De forma geral e não aprofundada, pode ser dito que preponderam países com dois tipos de perfis econômicos distintos; de um lado, os países que tiveram o processo industrial iniciado já nos fins do século $X X$, desenvolvendo uma indústria de base mais robusta para atender os interesses dos parques industriais com maior potencial tecnológico, formado pelos países de economias centrais; dentre os expoentes desse grupo temos a Argentina, o Brasil e o México. Nesses países ocorreram, de acordo com Vânia Bambirra (2012), um processo de substituição de importações e o deslocamento do bloco primário-exportador da direção hegemônica da sociedade, onde a produção da burguesia industrial nacional serviria como uma engrenagem para 
alavancar as grandes multinacionais formando uma integração monopólica. Do outro lado, um grupo formado por países com o parque industrial pouco desenvolvido e a base econômica agrário-exportadora; dentre os quais podemos situar a Bolívia. Assim, existe um desequilíbrio histórico no desenvolvimento capitalista entre dois grupos de países latino-americanos.

A manutenção da dependência econômica propiciaria a reprodução da dominação sofrida frente aos países de economia central em uma escala regional, a partir do subimperialismo. Assim, a situação do desenvolvimento capitalista dependente em países como Brasil, México e Argentina seria diferente da ocorrida com a Bolívia, conforme destaca Vânia Bambirra, pois,

[...] consistiram na exploração de um país dependente mais desenvolvido sobre outros menos desenvolvidos, em busca do controle de parte substancial de seus mercados, através não apenas de exportações, mas, sobretudo, de investimento em setores econômicos básicos - de recursos naturais ou de instalação de indústrias -, o que suporia um certo domínio político e militar por parte do país subimperialista (2012, p.218).

Logo, a reprodução da lógica dependente tende a desencadear práticas subimperialistas entre os países latino-americanos e afastar um processo de integração continental genuíno, necessário e baseado na solidariedade. A unidade latino-americana, fundada em valores distintos do que prega o mercado, é fundamental para enfrentar a política imperialista e a dependência histórica estabelecida. Na questão prática ela deve considerar os "riscos de se reproduzirem os mecanismos da divisão regional do trabalho, que acarretaria no aprofundamento da especialização produtiva de alguns países conforme a hegemonia de um ou outro país no interior do mesmo processo" (SEABRA, 2013, p. 198).

Trilhar rumos que rompam com a dependência é uma tarefa que interessa à real emancipação dos povos latino-americanos. No entanto, para isso ocorrer é essencial enfrentar o modo de produção capitalista. A atual Constituição boliviana, ainda sob o crivo do capitalismo, aponta possibilidades 
de construções alternativas, embora não dependa de um mero dispositivo constitucional para que o modo de produção seja alterado.

Cabe avaliar, nesse curto período de Estado Plurinacional, o que se avançou para o rompimento dessa dependência histórica e como as contradições surgem ao longo desse processo.

Uma das tensões criativas do bloco político que está no poder do Estado, diz respeito à dicotomia entre os interesses gerais do povo e aqueles interesses particulares de grupos da sociedade (GARCIA LINERA, 2012a, p. 41). Uma vez que as grandes mobilizações perderam o fôlego com a vitória do bloco histórico indígena-popular, em diferentes períodos após 2010, várias manifestações de setores sociais, como relacionadas aos povos indígenas das terras baixas, professores/as, profissionais da saúde, causaram um choque na unidade estabelecida.

Essa fratura no bloco popular gerou uma publicização ampla dos fatos a partir dos meios de comunicação privados, ainda de propriedade da elite política conservadora do país. O interesse corporativo era evidenciado e fragilizava o bloco histórico frente aos interesses do povo. Por outro lado, essas contradições são úteis pedagogicamente, pois contribuem para que as forças políticas populares saibam lidar com as divergências sem romper a unidade.

O vice-presidente Álvaro Garcia Linera extrai algumas lições desses episódios no processo, o qual considera revolucionário, e que continua a crescer na medida em que aprende a lidar com as contradições. É o que se evidencia quando afirma:

Esto mostró que pueden existir formas democráticas y formas revolucionarias para resolver las contradicciones al interior del pueblo, y que es importante el trabajo de ideologización del movimiento sindical urbano a fin de reforzar los planteamientos comunitarios, comunistas y socialistas debilitando los focos de la ideología privatizante, corporatista y exclusivamente salarialista que aún están presentes, especialmente por la 
acción de residuos de la derecha partidaria y del trotskismo. (2012a, p. 62)

Essas tensões decorrem dos rumos políticos tomados após a eleição de Evo Morales e, consequentemente, a promulgação da Constituição em 2009. A fragilidade histórica da economia boliviana faz com que o governo reforce a presença do Estado em setores estratégicos e parta para uma perspectiva proativa na participação e na vida do povo boliviano.

3.2.2. A nacionalização de setores estratégicos e o investimento na produção como formas iniciais de alteração do padrão econômico.

A forma encontrada de maior inserção nesses setores estratégicos da economia boliviana se dá com as nacionalizações: Já no ano de 2008 o presidente "Evo Morales decretou a nacionalização da ENTEL (Empresa de Telecomunicações) e quatro empresas petroleiras (REPSOL, TRANSREDES, CHACO e CLHB) que tinham entre seus acionistas empresas internacionais" (SCHAVELZON, 2010, p. 368-369). Com o passar dos anos, outras empresas são nacionalizadas como a YPFB, a ENDE, a Huanuni, a Vinto materializando, dessa forma, um maior controle dos recursos e garantindo uma redistribuição do excedente econômico para a população, algo visto como uma demanda universal dos trabalhadores/as.

A nacionalização dos hidrocarbonetos implica em uma decisão política fundamental para o controle dos recursos minerais e a demonstração de soberania. Essa postura política confirma a intenção em diminuir a subordinação aos interesses do capital estrangeiro, em todas as searas, desde a extração, seja do refino ao desenvolvimento tecnológico da produção 
boliviana. Essas nacionalizações, para Luis Tapia, poderão resguardar uma autonomia relativa do Estado através desse tipo de investimento frente a uma dominação direta da elite boliviana e internacional.

La coyuntura de autonomía relativa del estado es algo que se está financiando y se financiaría mientras dure la nacionalización de los recursos naturales. Probablemente el grado de recuperación del control de la propiedad y la renta actual no sea suficiente para un mantenimiento sostenido de la condición de autonomía relativa, y necesitará de la nacionalización de otros recursos naturales en el país y de un aumento de las regalías o un control general de los procesos de explotación de los recursos naturales. (...) Si la autonomía relativa implica distanciamiento respecto de los intereses de la clase dominante por parte de aquellos que dirigen el estado, en condiciones de los países periféricos articulados de manera altamente subordinada al sistema mundial, esto implica también distancia respecto de la clase dominante transnacional o de intereses capitalistas transnacionales y respecto de la soberanía de otros estados que han penetrado fuertemente el país (TAPIA, 2009b, p. 124-125).

Essas medidas confirmam o fortalecimento do Estado na vida social boliviana. Por mais que essas ações apresentem uma melhora no acesso dos serviços da população e uma maior segurança alimentar ${ }^{189}$, fica evidente que o rentismo dos hidrocarbonetos passa a definir a arrecadação do Estado boliviano. O processo revolucionário avança com a redistribuição de excedentes da renda dos hidrocarbonetos entre as classes subalternas, porém mantem uma lógica exploratória danosa ao meio ambiente, e em certa medida, aos trabalhadores/as.

\footnotetext{
189 "Hoy, con la inversión estatal, se está comenzando a industrializar el gas (con una planta de glp en Campo Grande, una planta separadora de gas en el Chaco, una Termoeléctrica en el Chapare ), se está relanzando actividades mineras metalúrgicas (Huanuni, Vinto, Corocoro, colas y desmontes, etc.), se está apoyando a los pequeños productores vinculados al mercado interno a través de la estatal Empresa de Apoyo a la Producción de Alimentos (emapa), a fin de garantizar la soberanía alimentaría del país, y se está creando fábricas para abastecer el mercado interno (de papel, de cartón de cítricos, leche, etc.)" (GARCIA LINERA, 2010a, p. 25).
} 
Os processos de nacionalização sofreram alguns questionamentos e críticas de grupos ligados ao campo popular por dois motivos: por um lado, porque mantinha a reprodução, a que me referi, da lógica rentista ${ }^{190}$ com a mera substituição de capitais privados por recursos públicos, o qual não aumenta a geração de empregos, nem a produção; por outro lado a política de expropriações de empresas garantia a essas, valores indenizatórios muito altos (LASERNA ROJAS et all, 2009). Essas críticas chamavam a atenção para a necessidade de investimento na produção, ao invés da mera utilização de excedentes econômicos para o investimento geral no país. Apesar de ser relevante salientar que o processo de mudança de uma política econômica neoliberal para o desenvolvimento produtivo requer um tempo razoável.

Contudo, após o início das nacionalizações de hidrocarbonetos, sobretudo, o Estado passa a ter um controle importante sobre as exportações do país e aumenta significativamente a arrecadação de divisas. Ademais, a introdução do Imposto Direto sobre os Hidrocarbonetos (IDH) ${ }^{191}$ e o aumento das exportações de gás natural também contribuem para esse maior acúmulo de divisas. Em 2005, o Estado arrecadou cerca de 677 milhões de dólares, já em 2008 essa cifra mais que triplicou para o valor de 2.100 milhões de dólares e em 2009 chegou a 2.329 milhões de dólares (GARCIA LINERA, 2010a, p. 24). O incremento dessas receitas fizeram que com que no ano de 2013 o PIB - Produto Interno Bruto - da Bolívia fosse cinquenta bilhões de dólares e a taxa de crescimento $6,5 \%$ no ano, uma das mais altas do mundo (MARTINS, 2014).

"Em termos de correlação de forças no campo econômico, o poder do capital externo debilitou-se bastante em áreas estratégicas (hidrocarbonetos e telecomunicações), perdendo fluxos financeiros, ativos e excedentes" (Tradução livre) (GARCIA LINERA, 2010a, p. 26). Além de perder o monopólio de preços em outros setores. Efeitos que atingem diretamente a vida da população.

\footnotetext{
190 "El rentismo refleja una creencia y una actitud que se basan en la idea de que la producción, la innovación y el intercambio no crean riqueza sino que ésta existe en la naturaleza y solamente hay que aprovecharla y distribuirla" (LASERNA ROJAS, 2009, p. 39).

${ }^{191}$ Aprovado pela lei $n^{\circ} 3058$.
} 
Mesmo com as críticas realizadas, os avanços na industrialização dos recursos naturais e a diversificação do parque tecnológico na Bolívia são notórios para um país que a pouquíssimo tempo atrás era o mais pobre da América do Sul. Uma das experiências mais entusiasmadas do governo diz respeito à produção da bateria de ión-lítio.

Esse empreendimento inicia-se nos marcos do Plano Nacional de Desenvolvimento, o qual instrui a COMIBOL - Corporação Mineira da Bolívia a criar dentro da sua estrutura um setor responsável pela industrialização dos recursos minerais evaporíticos do país com o projeto para ser explorado no Salar de Uyuni. A produção do Carbonato de Lítio (Li2CO3) e do Cloreto de Potássio $(\mathrm{KCl})$ não está aberta à participação de empresas estrangeiras sendo administrada e operada pelo Estado Boliviano.

A estratégia de industrialização desses recursos possui três fases:

1) A edificação da infraestrutura civil e das plantas piloto $\mathrm{Li} 2 \mathrm{CO} 3$ e $\mathrm{KCl}$. Ambas já inauguradas, uma no final de 2012 e a outra no início de 2013, projetadas para produzirem 40 toneladas por mês (Li2CO3) e 700 mil toneladas por ano (KCl). (BOLIVIA, 2013b, p.19-20).

2) Após a instalação piloto, se dá início a industrialização propriamente dita, com os ajustes para a otimização do processo produtivo. Iniciou-se também a construção do primeiro módulo de piscinas de evaporação para garantir a produção da matéria-prima. (BOLIVIA, 2013b, p.21).

3) Por fim, a terceira fase compreenderá a produção das baterias de iónlítio. Assim, o Estado boliviano apreende toda a cadeia produtiva deste recurso desde a extração da matéria-prima até a produção de baterias e sua comercialização. 


\begin{tabular}{|c|c|c|c|c|c|}
\hline DETALE & 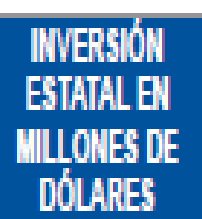 & $\begin{array}{c}\text { AlODOE } \\
\text { PRODUCCOLN }\end{array}$ & $\begin{array}{l}\text { FNAMICLA- } \\
\text { WIENTO }\end{array}$ & TECWOLOELA & 085. \\
\hline $\begin{array}{l}\text { FASEI } \\
\text { PILOTO }\end{array}$ & 18,5 & 20122015 & $\begin{array}{l}\text { 100\% Estado } \\
\text { bdiviano }\end{array}$ & bolivina & Concluda \\
\hline $\begin{array}{l}\text { FASE\| } \\
\text { |MDUSTRIAL }\end{array}$ & 465 & 2016 & $\begin{array}{l}\text { 100\% Estado } \\
\text { bolviano }\end{array}$ & bolviana & En desamolo \\
\hline $\begin{array}{l}\text { FASE II } \\
\text { BATERIAS } \\
\text { LTTOO }\end{array}$ & 400 & - & $\begin{array}{l}\text { 100\% Estado } \\
\text { boliviano }\end{array}$ & $\begin{array}{l}\text { Socios para } \\
\text { tranflerencia de } \\
\text { tecnologia }\end{array}$ & $\begin{array}{l}\text { Equipos y planta Piloto de } \\
\text { baterías en proceso de } \\
\text { acopio y envílo }\end{array}$ \\
\hline
\end{tabular}

Tabela 07 - Fases da estratégia de industrialização dos recursos evaporíticos. Fonte: (BOLIVIA, 2013b, p. 22).

Antes a contratação de serviços tecnológicos do Estado perante as companhias estrangeiras não previa a transferência da tecnologia ao fim do contrato. Hoje é diferente ${ }^{192}$, pois os acordos realizados com as empresas chinesa e sul-coreana preveem a transferência de tecnologia. Além do mais, preveem o treinamento de profissionais bolivianos/as para manejar a produção desse setor com a utilização dessas novas tecnologias.

Assim, além das plantas já montadas para processar carbonato de lítio e cloreto de potássio, no início de 2014, foi inaugurada uma terceira para a montagem de baterias ión-lítio para telefones celulares e bicicletas com tecnologia chinesa. Conforme destaca a reportagem do jornal pagina siete (2014), a fase de capacitação duraria quatro meses, em que os funcionários chineses trabalhariam com 21 profissionais bolivianos/as que estão responsáveis por operar a planta e, então, realizar a montagem das baterias para telefones móveis, câmeras fotográficas e bicicletas. Essa é uma possibilidade de dar um salto, que vai além do histórico econômico primárioexportador aplicado.

\footnotetext{
192 "En este contexto, en marzo de 2012, se firmó un Acuerdo de Principios para el establecimiento de una empresa de capital mixto para montar una Planta Piloto de materiales de cátodos con el consorcio coreano Kores-Posco, culminando en julio de 2012 con la firma del respectivo contrato bajo la modalidad de Joint Venture. Asimismo, la GNRE firmó un contrato con la empresa China LinYi Dake Ltda. para comprar una Planta Piloto de Baterías de ión Litio (...)" (BOLIVIA, 2013b, p. 21).
} 
Há ainda uma cooperação entre Bolívia e Venezuela para a produção conjunta de pilhas e baterias de lítio e com a Holanda para o desenvolvimento de equipamentos relacionados à bateria de lítio (BOLIVIA, 2013b, p. 62-64).

Iván Aranda, consultor da gerência nacional de recursos evaporíticos da COMIBOL - Corporação Mineira da Bolívia - (2013) aponta que o Estado, através da burocracia administrativa, atrasa 0 andamento desses empreendimentos, sendo necessário uma reforma administrativa do mesmo. Para ele, do ponto de vista econômico e técnico, os avanços são evidentes, mas as estruturas e o desenho administrativo ainda travam o desenvolvimento produtivo.

Aranda (2013) acrescenta que esses projetos têm uma função social e não é a de simplesmente valorizar o capital como na dinâmica de mercado. $A$ contribuição direciona um desenvolvimento técnico científico para o país e pauta-se, até certo ponto, pelo valor de uso. Além dessas questões, nesses empreendimentos existe um controle social para que haja maior respeito junto às comunidades e ao meio ambiente.

Um dos gargalos desse tipo de empreendimento é a questão ambiental, algo de extrema importância, sobretudo em um Estado que busca desenvolver-se economicamente sem distanciar-se da construção do vivir bien. Não é passível na atualidade, um produtivismo irresponsável que desconsidere as relações ambientais que estão em jogo. Qualquer empreendimento desse porte gera um impacto ambiental, o qual deverá ser reduzido ao máximo e justificado em razão da importância do produto que é desenvolvido.

No caso do empreendimento ligado à extração de matéria-prima para a produção da bateria de lítio algumas medidas são tomadas com o propósito de gerir uma política ambiental atrelada à produção ${ }^{193}$. Essas ações vão desde a construção de banheiros ecológicos aos incineradores de resíduos sólidos.

\footnotetext{
${ }^{193}$ As atividades relacionadas à política ambiental são as seguintes: Licença ambiental para eletrificação, licença ambiental das plantas industriais, consultas públicas em relação aos impactos, instalação de banheiros ecológicos e duchas portáteis, lixeiras para separação de resíduo sólido, capacitação profissional no ISSO 14001, responsabilidade social com a comunidade, incinerador de resíduos sólidos, planta de tratamento de água, entre outros. (BOLIVIA, 2012, p. 94-98).
} 
Cabe ressaltar que a construção das piscinas de evaporação no Salar de Uyuni também permitirá a obtenção de outros sais minerais que poderão ter valor agregado à aplicação industrial em outras áreas.

\begin{tabular}{|c|c|}
\hline Tipo de Sal & Usos comenteiales: \\
\hline \multirow{6}{*}{$\begin{array}{l}\text { Sulfato de Sodio } \\
\mathrm{Na}_{2} \mathrm{SO}_{4}\end{array}$} & Industria de detergentes \\
\hline & Industria química \\
\hline & Refinación de azúcar \\
\hline & Industria papelera \\
\hline & Industria textil \\
\hline & Industria del vidrio \\
\hline \multirow{3}{*}{$\begin{array}{l}\text { Sulfato de } \\
\text { Potasio } \mathrm{K}_{2} \mathrm{SO}_{4}\end{array}$} & Industria de fertilizantes (Agricultura) \\
\hline & Industria famacéutica \\
\hline & Industria de explosivos \\
\hline \multirow{3}{*}{$\begin{array}{l}\text { Clonuro de } \\
\text { Potasio KCl }\end{array}$} & Industria de fertilizantes (Agricultura) \\
\hline & Industria famacéutica \\
\hline & Industria Vidrio \\
\hline \multirow{2}{*}{$\begin{array}{l}\text { Bischofita } \\
\mathrm{MgCl}_{2} 6 \mathrm{H}_{2} \mathrm{O}\end{array}$} & Supresor del polvo y estabilizador de caminos \\
\hline & | Industria de la medicina \\
\hline
\end{tabular}

Tabela 08 - Sais minerais obtidos com a construção das piscinas de evaporação.

Fonte: (BOLIVIA, 2013b, p. 50).

Esse tipo de empreendimento agrega valor à economia boliviana e dá um suporte mais vigoroso a autonomia relativa do Estado frente às ingerências econômicas de outros países e da própria elite interna.

Eduardo Paz Rada ${ }^{194}$ (2013) chama a atenção para alguns fatos que pressupõe o fortalecimento das economias plurais. Para ele é fundamental alguns pressupostos, como a condução do Estado de setores estratégicos e a consequente diminuição da influência das transnacionais, desenvolvendo nesse momento inicial, um capitalismo de Estado para poder lograr êxito em outros pontos. Segue analisando que, em países semicoloniais como a Bolívia, o fortalecimento de um Estado de cunho popular é a base para um salto, inclusive ao socialismo, pois assim, a economia imperialista, encabeçada pelas transnacionais, teria condição de ser erradicada da região. Conforme Paz Rada (2013), um Estado frágil não sustentaria por muito tempo as mudanças de padrão econômico e político que a Bolívia busca efetivar.

\footnotetext{
${ }^{194}$ Professor de sociologia da Universidade Mayor de San Andrés.
} 
Alguns caracterizaram esse processo como parte de um capitalismo andino amazônico (GARCIA LINERA, 2006), uma etapa fundamental para alcançar mais à frente uma espécie de socialismo comunitário ${ }^{195}$. Essa teoria não foi poupada de críticas por parte daqueles que falavam que se tratava, na prática, somente de um novo modelo nacional produtivo e que agora prezava também os investimentos privados, inclusive internacionais, em detrimento da economia comunitária (ICHUTA NINA, 2012).

O fato é que o Estado assume um papel ativo na condução econômica da Bolívia. Em 2013 é aprovada a lei n³93, a qual regula os serviços financeiros. O Estado passa a ter um maior controle sobre a circulação desse capital, algo que não ocorria anteriormente. Os bancos não possuem mais autonomia para fixar as taxas de juros para empréstimo e poupança de acordo com seus meros interesses, restringindo a atuação do mercado financeiro. $O$ Estado como indutor da economia cumpriria esse papel através dos decretos supremos.

3.2.3. O fortalecimento da pluralidade econômica como próxima etapa para possibilitar a materialização do vivir bien.

Uma das grandes dificuldades para que o avanço revolucionário esteja possibilitado na Carta Constitucional está inserido no ponto que trata da organização econômica do Estado. Por mais que haja um fortalecimento do

\footnotetext{
195 "El potencial comunitario que vislumbraría la posibilidad de un régimen comunitarista socialista pasa, en todo caso, por potenciar las pequeñas redes comunitaristas que aún perviven y enriquecerlas. Esto permitiría, en 20 o 30 años, poder pensar en una utopía socialista" (GARCIA LINERA, 2006).
} 
Estado, a partir das nacionalizações e da sua efetiva intervenção, a revolução pós-capitalista ainda não ganhou corpo. O fato de existir uma previsão constitucional contemplando uma pluralidade de práticas econômicas, ressaltadas pela economia comunitária e social cooperativa ${ }^{196}$, não se propôs até então, a minar os pilares do capitalismo.

A estrutura em que a sociedade está assentada, não mudará seu eixo com uma mera orientação política a partir da concepção do vivir bien. A Constituição não enfrenta radicalmente a classe proprietária dos meios de produção, o que permite a continuidade de uma matriz econômica ainda liberal.

Assim, o capitalismo dependente continua vivo na realidade da Bolívia, embora a postura do Estado comece a quebrar sua forma hegemônica de manifestação ao assumir o controle dos mecanismos econômicos. As mudanças nesse âmbito ainda não foram suficientes para evitar a superexploração ${ }^{197}$ do trabalhador/a e a continuidade da transferência permanente de valor das periferias econômicas para os grandes centros. Mas, os avanços para enfrentar a dependência, como exemplificado, a partir de uma nova postura interventiva do Estado e com um direcionamento econômico plural aparentam iniciar.

A crítica a uma pretensa política desenvolvimentista praticada na Bolívia não deve ocorrer sem uma percepção e leitura histórica. As políticas extrativistas com um cunho colonial compõem um legado que parte ainda da colônia espanhola passa pela república e chega ao Estado Plurinacional. Não é uma política econômica criada pelo governo de Evo Morales, mas uma herança de um padrão de desenvolvimento que atinge os países latino-americanos de alguma forma (GONSALVEZ, 2012, p. 176). O Estado Plurinacional começa a trabalhar algumas possibilidades desde a economia plural, o que será um desafio para avançar sobre o modo de produção capitalista.

\footnotetext{
${ }^{196}$ Artigo 306 da Constituição boliviana.

197“Chamada para contribuir com a acumulação de capital com base na capacidade produtiva do trabalho, nos países centrais, a América Latina teve de fazê-lo mediante uma acumulação baseada na superexploração do trabalhador." (MARINI, 2005, p. 162).
} 
O desenvolvimento da pluralidade econômica terá dificuldade para interferir em uma correlação de forças diferenciada, suficiente para romper com o ciclo de dependência e subordinação econômica vivenciado na América Latina. Contudo, novas possibilidades são criadas em decorrência dessa previsão, além de reconhecer a dinâmica de funcionamento econômica já praticada pelas comunidades. Um processo revolucionário, de fato, deverá, em um determinado momento, enfrentar o modo de produção estabelecido nas relações econômicas.

Assim, a perspectiva plurinacional intrincada no âmago da Nova Constituição Política do Estado boliviano poderá ousar mais na condução das políticas econômicas dadas e propostas. Caso assim não proceda, correrá o risco de limitar-se à reprodução liberal e ao domínio econômico setorizado ${ }^{198}$.

\begin{abstract}
Primeramente, al definir que el modelo económico es plural exige una comprensión distinta de la economía y la articulación de las formas organizativas económicas, ya no es constitucional pretender establecer un "modelo de crecimiento y desarrollo" o, en todo caso, podemos tratar de un nuevo modelo económico plurinacional productivo enfocado a potenciar el carácter plural de las economías. (...) Segundo, se nombran las diferentes formas de organización económica, para lo cual se requerirá normativas e instancias institucionales para su desempeño. Los mecanismos y estrategias para su relacionamiento, vinculación y función que aún no tienen los instrumentos y dispositivos necesarios. (VEGA CAMACHO, 2010, p. 150).
\end{abstract}

Todas essas previsões constitucionais só terão valia, caso os mecanismos políticos, econômicos e jurídicos funcionem ou caminhem na perspectiva de não manter o vício das Constituições liberais tradicionais, consideradas só uma carta de intenções. Essas mudanças parecem configurar uma realidade, mesmo que ainda limitada.

\footnotetext{
${ }^{198}$ As reformas que foram feitas, caso sejam bem executadas, no curto prazo, podem trazer alguns resultados, mas, no longo prazo, a estrutura de reprodução econômica da sociedade permanecerá sendo ditada por um núcleo que é, em certa medida, "uni-nacional" (MOTA, 2009, p. 149).
} 
Quanto ao vivir bien, a expressão indica a forma que se busca conjugar a dinâmica econômica boliviana com o desenvolvimento social, tal como preveem os preceitos constitucionais; incentivar e fortalecer os modos de organização econômica existentes em níveis comunitários também é importante. Na Bolívia a economia moderna e globalizada abarca cerca de $28 \%$ da população boliviana, a economia campesina tradicional, composta por 550 mil unidades familiares, comporta em torno de $35 \%$ e a economia mercantil familiar-artesanal, com uns 700 mil estabelecimentos urbanos agrupam $37 \%$ da população nacional (GARCIA LINERA, 2008, p. 353).

Gonzalo Gonsalvez indica algumas tarefas imprescindíveis para que o Estado possa avançar na construção de uma economia plural. A primeira tarefa é a de controlar os recursos estratégicos e administrá-los bem. A segunda é redistribuir os recursos desse setor ao conjunto da sociedade, sobretudo aos que mais necessitam. O terceiro é fortalecer e ampliar o aparato produtivo com a industrialização dos recursos naturais. Essas três tarefas iniciais estão em andamento. A última é orientar a economia para a transformação (2012, p. 159). Pois, a dinâmica econômica se diversificará dependendo do contexto real. Os ayllus, por exemplo, devem ter garantidas as possibilidades de desenvolvimento desde a própria lógica de existência.

Algumas experiências concretas exemplificam isso.

En primer lugar, es importante mencionar al ayllu, ubicado principalmente en el norte de Potosí y sur de Oruro, aunque también en parte de Cochabamba y La Paz, tiene una fortaleza comunitaria bastante densa que proviene de la articulación de toda su dimensión económica: articula a un conjunto muy grande de comunidades, posee una propiedad común de la tierra y una organización colectiva, formas colectivas de trabajo y circulación de los productos, control efectivo de dos o más pisos ecológicos, una organización política funcional a estas características económicas comunitarias, formas de distribución social de la riqueza y de los riesgos productivos, etc. El ayllu mantiene una densidad comunitaria impresionante, las TCO son en parte un intento por reconstituir esta experiencia pero con muchas dificultades en regiones donde la mercantilización de la vida a avanzado (GONSALVEZ, 2012, p. 161). 
O interessante é que o perfil econômico comunitário busca atender as necessidades básicas para a sobrevivência e reprodução daquele grupo social, ao invés de objetivar o lucro com a produção. Essa lógica distinta ocorre tanto na produção, quanto na circulação de bens, distribuição de tarefas comunitárias e funções que tendem a melhorar a atividade laborativa. Nem sempre as organizações comunitárias estão alheias ao mercado, mas é notório que, em geral, elas funcionam historicamente resistindo e adaptando-se a partir da sua lógica de funcionamento e independente deste. O sujeito atuante da economia comunitária é uma realidade na Bolívia ${ }^{199}$, não precisa ser criado para dinamizar a pluralidade econômica (GONSALVEZ, 2012, p. 164). Além da concretude do sujeito, mais do que local, a economia comunitária tem uma força global, justamente porque não está subsumida ao capital. Ela produz 0 valor, desde a necessidade do produto para a comunidade ${ }^{200}$. A produção camponesa em propriedades familiares, sem a lógica da propriedade comum, também configura um padrão econômico muito utilizado na Bolívia. A combinação de formas econômicas liberais e comunitárias abre flancos para o aprofundamento democrático, construção de consensos e o avanço para que em um futuro, não tão distante, a sociedade esteja cada vez mais forte com mais comunidade e menos Estado.

$\mathrm{Na}$ crescente economia urbana, sobretudo em cidades do altiplano andino, como El Alto, onde houve uma forte expansão demográfica ao longo do período neoliberal, as práticas do ayllu servem de parâmetro para o exercício das atividades. No entanto, a condição comunitária do sujeito indígena naquela situação é, em boa parte das vezes, subsumida pela lógica do capital. Assim, as pequenas unidades produtivas de El Alto, em sua maioria ligada aos empreendimentos têxteis, reproduzem uma relação de exploração entre os

\footnotetext{
${ }^{199}$ ANEXO J - Mapa, ainda do início dos anos 2000, que indica as áreas na Bolívia formadas por Terras Comunitárias de Origem (TCO).

200 “(...) debe motivar la constitución de empresas comunitarias, rurales o urbanas, pequeñas, medianas o grandes, em las que la característica principal se ala propiedad colectiva de los medios de producción y la apropiación directa del resultado del trabajo". (MOLDIZ MERCADO, 2012, p. 215)
} 
membros da família e empregados/as por meio de baixa remuneração possibilitando um maior acúmulo de capital. Algo que caracterizará o exercício da superexploração abordada por Ruy Mauro Marini ${ }^{201}$. Logo, não se trata de mero trabalho comunal familiar desenvolvido por aymaras (PUENTE; LONGA, 2007 , p. 104). As características mais comunitárias ainda estão ligadas às zonas mais empobrecidas e, sobretudo, na área rural.

A economia plural boliviana apresenta elementos que indicam o início de uma transição, que saiu de um modelo neoliberal para um modelo com carga social forte. Porém, além do modelo, resgata um tipo de sistema civilizatório pautado no vivir bien, ou seja, aposta nos grupos formadores da sociedade boliviana como protagonistas de um novo período histórico.

Um processo revolucionário dentro de uma perspectiva econômica requererá transformações permanentes, como o estímulo à substituição da tecnologia capitalista herdada por outras tecnologias alternativas desenvolvidas com base nos conhecimentos ancestrais e populares, atreladas ao respeito à "Mãe Terra" (GONSALVEZ, 2012, p.178). Isso necessitará de muito investimento técnico e pessoal para a gestão desse novo direcionamento produtivo, ao invés da reprodução econômica do status quo. Essa nova possibilidade de reflexão econômica e civilizatória decorre dessa herança inovadora que também se faz presente com o vivir bien.

Es ahí, en la producción, que la fortaleza comunitaria tiene ya un capacidad heredada (control comunitario del agua, acceso a la tierra, pastos comunales, rotación de cultivos, formas de circulación de la fuerza de trabajo) que puede ser el punto de partida de una intensificación interna en el propio proceso de producción local (familiar-comunal) y en la articulación productiva con otras comunidades. Es en la creación de un nuevo modo de producción material crecientemente socializado, expansivamente comunitarizado que se juega el destino postcapitalista de la sociedad y del mundo y es ahí donde podrían comenzar a concentrarse las potencias, las energías autónomas comunitarias de los sindicatos y de los ayllus. (GARCIA LINERA, 2012a, p. 37).

${ }^{201}$ Cf. Capítulo 1, ponto 1.1.2. 
O desenvolvimento econômico passa a ser refletido, então, desde uma ruptura epistemológica com o estabelecido, partindo de diálogos interculturais profundos, os quais não concebem 0 homem/mulher separados da pachamama. Na Bolívia, o capitalismo e o colonialismo sempre caminharam juntos. A saída de uma lógica econômica extrativista ou desenvolvimentista passa também por esse horizonte de superação desses dois elementos. Mesmo a necessária industrialização dos recursos naturais nesse primeiro momento, tal como acontece, não deve deixar de orientar-se pela construção do vivir bien na sociedade boliviana. Assim, a produção estimulada pela industrialização boliviana, não deve se deter a abastecer o mercado, mesmo através de produtos com valor agregado, como no caso das baterias de iónlítio. O desenvolvimento gerado deve direcionar também a uma produção de conhecimento que extrapole as possibilidades de mercado, rompa com a reprodução da dependência e com os direcionamentos voltados à volúpia capitalista. Um desafio cabível aos que ousam trilhar um caminho revolucionário, ou seja, de ruptura. Obviamente, guiar-se pela cosmovisão indígena não pode significar a exotização desse modo de vida. Em uma sociedade que se urbaniza cada vez mais, as formas intermediárias devem ser estimuladas, garantindo um processo de transição e a construção da desmercantilização de espaços da vida social para que não se caia em um fetichismo constitucional (STEFANONI, 2012).

Como afirma Moldiz Mercado,

[...] un periodo de transición caracterizado por una alta regulación del capital vía estatal, se vaya fortaleciendo la economía estatal y, paralelamente, alentando e impulsando la re-estructuración de la economía comunitaria. De hecho, la combinación de una fuerte presencia estatal y una rigurosa economía comunitaria dentro de la formación social boliviana es lo que debería suceder en la perspectiva del vivir bien o el "Socialismo comunitario" emancipador (2012, p. 217).

Articular essa estrutura econômica à superestrutura jurídica-política forjará o panorama fundamental para a consolidação de uma perspectiva 
emancipadora do bloco histórico, tal como prevê Gramsci. A classe trabalhadora crescente aliada aos povos indígenas e campesinos tem uma ampla possibilidade de aprofundamento do processo revolucionário. Uma vez que consigam manter a unidade do bloco e acertem na estratégia política de construir, através de um projeto popular, um Estado que supere, inclusive os anseios do Estado Plurinacional.

\subsection{O processo concreto das autonomias e a questão agrária na} reordenação territorial boliviana.

3.3.1. Uma proposta agrária antimonopólica e saneadora de terras

A reestruturação territorial é outra novidade legitimada pela Constituição do Estado Plurinacional da Bolívia. A questão agrária e a demanda por autonomias sempre foram pontos latentes no país, manifestada de diferentes formas pelos diversos grupos sociais bolivianos.

No que tange a reforma agrária, propriamente dita, ela foi uma pauta política forte na revolução nacionalista de 1952. Àquela época, ela foi implementada nos moldes clássicos, sem considerar devidamente as formas comunitárias de vivência no interior boliviano.

A Constituição atual opta por reforçar o que foi proclamado na Lei de Recondução Comunitária da Reforma Agrária (Lei n³545) de 2006. Dentre os aspectos mais relevantes, cabe salientar a possibilidade de reversão $0^{202}$ da terra

\footnotetext{
202 A reversão consiste no retorno da terra ao domínio do Estado sem a concessão de indenizações. Diferentemente da expropriação, que na Bolívia, realiza-se mediante indenização.
} 
no caso de descumprimento da função econômico-social, visto que é importante prezar pelo interesse social e pela produção.

Os preceitos constitucionais de 2009 apontam para a busca da diminuição do latifúndio e o limite da propriedade agrária para o máximo de cinco mil hectares, como já destacado. No entanto, existiam alguns pontos problemáticos na negociação desse dispositivo e que acabaram restringindo a política de reforma agrária. Um deles está na retirada do conteúdo normativo que colocava como retroativa à limitação da extensão da área de cinco mil hectares. Sendo assim, a remoção desse trecho na Constituição garantiu àqueles que possuíam áreas maiores que cinco mil hectares, antes da promulgação em 2009, teriam o direito de mantê-las. Para Félix Becerra (2013) da CONAMAQ, a manutenção de latifundiários nas terras mais extensas que cinco mil hectares, por causa da não retroatividade do dispositivo constitucional, representa um limite à descolonização real em alguns pontos do processo político boliviano.

Para o Vice-ministro de Terras na primeira gestão do governo Evo Morales, Alejandro Almaraz, para fins de redistribuição de terras, a disposição que limita a superfície da propriedade não tem tanta relevância. Pois, para ele, sua real importância está no fato de tratar-se de disposição antimonopólica, que visa evitar a concentração de um modo de produção, a terra, e propiciar a desconcentrar as atividades econômicas produtivas desenvolvidas nela (2010, p. 182). Assim, a Constituição consolida um processo de distribuição de terra que já estava em andamento em 2006.

De toda forma, a expropriação das propriedades que excederem o tamanho máximo da propriedade agrária chama a atenção, não sendo possível ultrapassar os cinco mil hectares de superfície. Uma proposta que limita o tamanho da propriedade, impedindo a progressão dos latifúndios, com a fundamentação no interesse coletivo e no desenvolvimento do país. Isso representa também uma demonstração da conservação do regime de propriedade privada de maneira atenuada e com maior intervenção do Estado. 
A ligação de poder político com a concentração da terra não é algo novo. Os departamentos da "Meia Lua", no oriente boliviano, historicamente elegeram representantes latifundiários aos cargos estatais devido à força econômica desse setor na região. Ali, a desconcentração de poder implica uma ação mais contundente da política de reforma agrária para consolidar, o que Luis Tapia chama de autonomia relativa do Estado frente ao poder econômico da oligarquia regional.

\begin{abstract}
Una de las principales formas y extensiones de la situación instrumental del estado era que los principales latifundistas y ganaderos del oriente, la amazonía y el chaco fueran los diputados y los senadores que representaban su departamento en el parlamento boliviano. Cuando se inició la municipalización también fueron candidatos a alcaldes y concejales; los candidatos a estos cargos públicos eran asimismo empleados de los principales latifundistas de la región. En estas condiciones de estructura patrimonial en estos territorios, el desarrollo de autonomía relativa implica una reforma agraria, es decir, una redistribución de la tierra. (TAPIA, 2009b, p. 127).
\end{abstract}

Uma das funções da efetivação da reforma agrária é garantir, por meio da democratização do acesso à terra, um maior bem-estar ao povo, além de empoderá-lo em decorrência da segurança e domínio patrimonial que passa a exercer. $O$ território ${ }^{203}$ e a terra, como meios de produção, poderão gerar vida e alimentos, ao invés de ser mero instrumento a atender os interesses do mercado.

Desde 2006, os procedimentos de regularização fundiária na Bolívia avançaram bastante, viabilizando com esse saneamento, a retirada ou a consolidação das propriedades. O mero fato do Estado assumir essa tarefa demonstra uma postura distinta da que já teve em um passado recente, quando direcionava às transnacionais milhões de dólares, que tomava de empréstimo com o Banco Mundial, para cumprir uma atividade relacionadas à

203 "Se han constituido 45 nuevas comunidades campesinas indígenas originarias interculturales asentadas en 118.540 hectáreas en los departamentos Pando, Santa Cruz, Beni y La Paz" (BOLIVIA, 2012, p. 30). 
regularização fundiária, ou seja, terceirizando algo que implica na soberania de um país.

Dentre algumas reversões emblemáticas, estão as ocorridas no Departamento de Santa Cruz, onde em dezembro de 2009, o Instituto Nacional de Reforma Agrária (INRA) declarou ilegal, por não cumprir a função econômica-social, a fazenda Yasminka de 12.587 hectares, de propriedade da família Jakuvek-Marinkovic ${ }^{204}$. Da mesma forma, as fazendas "El Encanto" e "La Encrucijada", localizados no município de Puerto Suárez, propriedade do empresário crucenho Osvaldo Monasterio Nieme, também reverteram 2.914 hectares de terra. Essas foram direcionadas aos povos originários da Central de Organizações dos Povos Nativos Guarayos do departamento de Santa Cruz. (FUNDACIÓN TIERRA, 2010).

Além disso, em outubro de 2013, é promulgada a lei n429 que amplia o saneamento ${ }^{205}$ das terras na Bolívia até 2017. Essa era uma demanda dos movimentos sociais do país, a não interrupção dos processos saneadores e a consequente política de reforma agrária. De acordo com os números do governo, entre 2006 e 2013, "foram saneados mais de 57 milhões de hectares beneficiando 1.117.804 famílias com um custo por hectare de 1, 8 dólares" e não mais os 10 dólares por hectare que era direcionado às transnacionais para que exercessem essa função antes de 2005 (BOLIVIA, 2013c).

A intenção é que o processo de saneamento de terras chegue a 106 milhões de hectares sob um custo de 89 milhões de dólares (BOLIVIA, 2013c). Contudo, mesmo com esses avanços o governo ainda tem dificuldades para realizar o saneamento das terras na Bolívia. Inclusive, a política agrícola relacionada ao agronegócio, ganha muita força a ponto de prever uma expansão para os próximos anos de três milhões para treze milhões de hectares plantados (URIOSTE, 2013). Uma das produções que mais crescem

\footnotetext{
${ }^{204}$ Yasminka Marinkovic, proprietária da fazenda, é irmã de Branko Marinkovic, líder cívico da direita boliviana, que vive no Departamento de Santa Cruz.

205 O saneamento implica na regularização, verificação de cumprimento da função socioambiental e reversão das terras na Bolívia.
} 
na Bolívia é a de plantio da soja, direcionado ao mercado externo, estimulado, sobretudo, por produtores brasileiros, conforme destaca Heloisa Gimenez (2010). Isso resulta preocupante, pois vai de encontro com os objetivos de construção de uma nova perspectiva agrária e econômica que rompa com a subordinada política de dependência e esteja atrelada ao vivir bien.

3.3.2. Os entraves e a implantação da autonomia como elemento chave da plurinacionalidade.

Em determinadas situações da dinâmica política boliviana é fundamental chamar a atenção para a amplitude de um processo revolucionário em curso e a sua direção, pautada na vanguarda compartilhada de indígenas, campesinos/as e trabalhadores/as. A partir desses setores, o andamento do projeto popular plurinacional deve incorporar outros setores sociais, sem perder a hegemonia política conquistada.

Jorge Viaña (2013) aponta como tema central do Estado Plurinacional, a possibilidade de desestruturar as lógicas liberais e reconstruir formas de autogoverno. As autonomias indígenas apresentam germes dessa possibilidade apontada no Estado Plurinacional.

No entanto, a ampliação de acordos para a inserção de novos setores não deve desvirtuar o aprofundamento do projeto político posto. Garcia Linera tratará isso como uma tensão secundária, que caso esses acordos não sejam regulados de forma devida, tem o potencial de tornar-se uma tensão principal e fraturar definitivamente o bloco histórico (2012a, p.40).

Assim, a autonomia é uma das bandeiras políticas que são reivindicações históricas, porém devem ser desenvolvidas com cautela e sem o risco de diminuição de poder político desse campo popular. Contudo, a demora 
demasiada do seu andamento inquieta a base indígena, que aguarda esse reconhecimento há mais de 500 anos de um domínio colonial. Conforme, destaca Rafaela Pannain, "[...] uma nova lógica estatal deveria ser criada, mas, este processo ocorreria a partir de instituições e lógicas que haviam sobrevivido ao período de grave crise política vivido nos anos precedentes" (2014, p. 222).

Quando o tema diz respeito às autonomias, várias questões são levantadas; a mais inovadora e interessante delas trata das autonomias indígenas originárias campesinas, pois ainda existem dificuldades na operacionalização dessa previsão constitucional. No entanto, a criação de um Ministério para abordar a questão, ajudou a viabilizar os processos de conversão de base municipal às Autonomias Indígenas Originárias Campesinas através de referendo. Certamente, há algumas exigências para o andamento do processo autonômico, que dificultam a sua efetivação, como a comprovação de certificado de ancestralidade e a declaração de que as comunidades podem se autogovernar, por exemplo. No país, doze municípios optaram por realizar esse referendo e desses, onze pronunciaram-se a favor da conversão. A partir dessa decisão, um órgão deliberativo ${ }^{206}$ é formado para a criação do Estatuto Autonômico.

${ }^{206} \mathrm{Na}$ composição desse órgão deliberativo é obrigatório que ao menos $30 \%$ dos membros sejam integrados por mulheres. 


\begin{tabular}{|c|c|c|c|}
\hline $\mathbf{N}^{\circ}$ & $\begin{array}{c}\text { MUNICIPIOS EN CONVERSIÓN } \\
\text { AIOC }\end{array}$ & \% por el SI & $\begin{array}{c}\mathbf{N}^{\circ} \text { de miembro Órgano } \\
\text { Deliberativo }\end{array}$ \\
\hline
\end{tabular}

\begin{tabular}{|l|l|l|l|}
\hline 1 & Uru Chipaya & 91.1 & 45 \\
\hline 2 & Jesús de Machaca & 56.9 & 47 \\
\hline 3 & San Pedro de Totora & 74.5 & 45 \\
\hline 4 & Mojocoya & 88.3 & 106 \\
\hline 5 & Pampa Aullagas & 83.6 & 60 \\
\hline 6 & Charagua & 55.7 & 46 \\
\hline 7 & Huacaya & 53.7 & 29 \\
\hline 8 & Tarabuco & 90.8 & 95 \\
\hline 9 & Charazani & 86.6 & 65 \\
\hline 10 & Salinas Garci Mendoza & 75.0 & en conformación \\
\hline 11 & Chayanta & 59.8 & en conformación \\
\hline
\end{tabular}

Tabela 09 - Municípios que optaram por converter-se em autonomias indígenas originárias campesinas.

Fonte: (BOLIVIA, 2012, p. 26-27).

O Ministério de Autonomias dará um suporte técnico na confecção desses projetos de Estatuto. Até 2012, já haviam concluído o projeto de estatuto autonômico cinco municípios que buscam a conversão: Uru Chipaia, Jesús de Machaca, San Pedro de Totora, Mojocoya e Pampa Aullagas. (BOLIVIA, 2012, p. 27). Dentre os objetivos impulsionados pelo Ministério das Autonomias e que devem ser desenvolvidos nas pretensas autonomias indígenas originárias campesinas estão as seguintes:

- Erradicar a extrema pobreza e a fome;

- Lograr ao aprendizado primário universal;

- Promover a igualdade entre os gêneros e a autonomia da mulher;

- Garantir um meio ambiente sustentável;

- Possibilitar um desenvolvimento local para alcançar o "bien vivir";

- Recuperar e revalorizar a identidade cultural" (Tradução Livre) (BOLIVIA, 2012, p. 27).

A Lei Marco de Autonomia e Descentralização (Lei n031 de 2010) também orientará as formas de governos e funcionamento das entidades territoriais autônomas. A gestão dos acordos, com as normas e os procedimentos da própria comunidade, desenvolve-se pela maneira peculiar de 
cada povo. Além das próprias entidades, os povos e as nações indígenas participam politicamente das esferas formais do Estado, sejam nos Departamentos ou Municípios ${ }^{207}$.

Apesar de algumas queixas pela demora na efetivação do reconhecimento, as ações concretas avançam. O primeiro estatuto autonômico indígena foi declarado constitucional no início de 2014, no então município de San Pedro de Totora. Os povos da localidade estão bem próximos de iniciar o autogoverno e alcançar a autonomia.

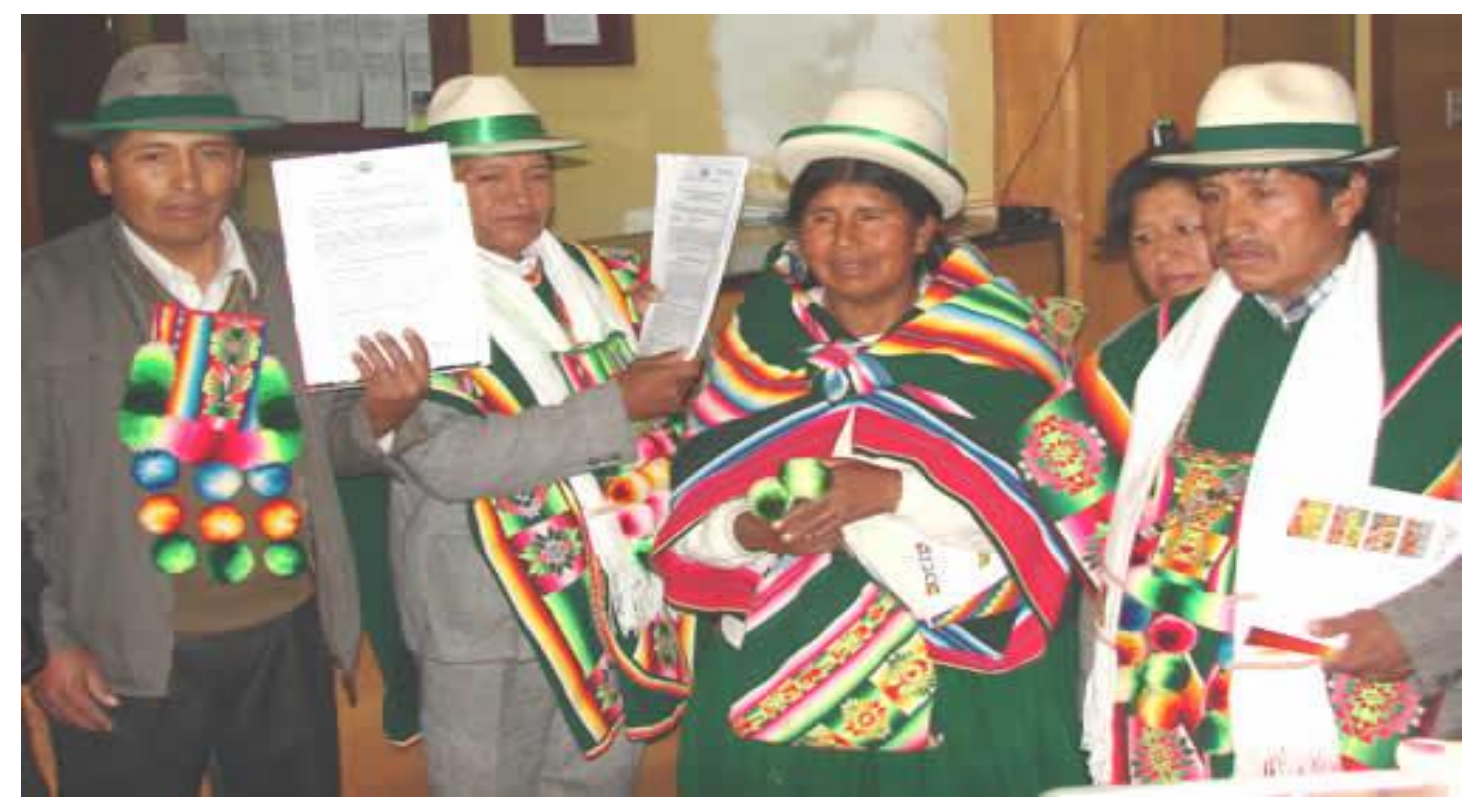

Foto 10 - Autoridades originárias recebem a declaração de constitucionalidade do estatuto autonômico de Totora.

Fonte: (FUNDACIÓN TIERRA, 2014)

Para chegar a este ponto o caminho trilhado contou com um referendo para conversão em autonomia indígena no ano de 2009. Na sequência, em 2012, o Estatuto é entregue ao Tribunal Constitucional Plurinacional. Em Junho de 2013, o Tribunal aprova a declaração com observações sobre o Estatuto, publicando-o em setembro. A comunidade saneia as observações feitas pelo Tribunal e reapresenta o estatuto ao mesmo. Agora com a declaração de constitucionalidade, só faltará a realização do referendo de aprovação do

207 ANEXO L - Membros de povos e nações indígenas componentes das Assembleias Legislativas Plurinacional, Departamental e Regional do Chaco. 
estatuto pela comunidade. Assim, pela primeira vez, o Estado Boliviano reconhecerá institucionalmente o exercício de autogoverno em um território próprio por um povo aymara (FUNDACIÓN TIERRA, 2014).

Desse modo, fica evidente que as nações e os povos indígenas terão a chance de exercer tanto o autogoverno em seus territórios, quanto participar das esferas municipais, departamentais e central do Estado Plurinacional. Só dessa forma para possibilitar que uma construção plurinacional tenha legitimidade perante o povo, ator dessa construção e, consequentemente, do seu próprio destino.

Garcia Linera, em relação ao assunto, considera:

Sin embargo, para que estas formas de autogobierno indígenas a nivel local, regional o nacional no generen procesos centrífugos que habiliten tendencias separacionistas del Estado boliviano y, además, para completar la desmonopolización étnica de la estructura macro o general del Estado boliviano a fin de consolidar el reconocimiento a escala superior de las comunidades culturales y regiones lingüísticas indígenas, se requiere, simultáneamente a estos procesos de construcción autonómicos, una redistribución de competencias entre el Estado y el gobierno autonómico y una presencia real y proporcional de las comunidades culturales indígenas en la composición de sistema de instituciones y poderes que regulan la comunidad política superior del Estado boliviano (2007b, p. 77).

A distribuição de competências é fundamental para a própria construção do Estado Plurinacional, a qual deve se dar ativamente pelos povos e comunidades que o compõe. Contudo, cabe chamar a atenção para algo fundamental nessa análise. Os indígenas que vivem em áreas autonômicas estão representados e participam dos órgãos centrais do Estado, mas falam desde uma representatividade territorial formal limitada ao Departamento; ou seja, a fala desses povos não partem diretamente dos próprios territórios, mas dos seus territórios localizados nos respectivos Departamentos. Percebem-se 
as contradições na construção do Estado Plurinacional de forma mais nítida, pois parte da estrutura colonial ainda permanece. Não há como negar um reconhecimento dos direitos indígenas, embora captados como individualidades empíricas (NOGUERA FERNANDÉZ, 2010, p. 99), não como direito dos povos indígenas, categoria que está relacionado diretamente ao território que ocupam.

No entanto, a efetivação de autogovernos nas entidades territoriais autônomas dos povos e nação indígenas só é viável, se não colocar em risco a perda da hegemonia do projeto político popular, ou revolucionário, conforme propalado. Para isso, o Estado Central não deve abrir mão de controlar determinados setores, por exemplo: as Forças Armadas, os recursos naturais, - Banco Central, as relações internacionais, as fontes energéticas, a Polícia Nacional dentre outros de caráter estratégico (GARCIA LINERA, 2007a, p. 7071). Assim, é possível garantir um avanço seguro e consistente do processo político sem que se avizinhe a sanha da elite oligárquica boliviana.

Um ponto importante, merecedor de destaque, trata da questão do processo de consulta pública nas situações em que fosse necessário realizar extração de hidrocarbonetos em territórios comunitários, já que os impactos causados por esses empreendimentos tornam a consulta algo fundamental para encontrar saídas à extração dos recursos naturais com um menor choque possível ao meio ambiente e à dinâmica social da localidade.

Ao longo da consulta pública, alguns procedimentos devem ser respeitados para que atinjam seus objetivos. Em um primeiro momento ocorrerá uma convocatória direcionada à comunidade, e a partir daí os povos indígenas atingidos terão um prazo para apresentarem um plano com alguns pressupostos ao Estado para a ocorrência da consulta pública. Após essa etapa haverá a execução da consulta, conforme o acordado, e assinado a ata validando o acordo entre o Estado e os povos indígenas (BOLIVIA, 2012, p. 34). 
Alguns dados de 2011 apontam a realização de consultas públicas aos povos e nações indígenas na Bolívia, tal como ilustra o quadro abaixo em destaque.

\begin{tabular}{|l|l|l|}
\hline \multicolumn{1}{|c|}{ EMPRESA } & \multicolumn{1}{|c|}{ PROYECTO } & \multicolumn{1}{|c|}{$\begin{array}{c}\text { PUEBLOS INDIGENA } \\
\text { ORIGINARIO CAMPESINO }\end{array}$} \\
\hline BG Bolivia & $\begin{array}{l}\text { Perforación Pozos PMO 7 y } \\
\text { PMO 8, Campo Palo Marcado }\end{array}$ & Weenhayek \\
\hline YPFB Chaco & $\begin{array}{l}\text { Prospección Sísmica 3D, Campo } \\
\text { Katari Bulo Bulo }\end{array}$ & $\begin{array}{l}\text { Federación Mamoré - Bulo Bulo / } \\
\text { Federación Carrasco Tropical }\end{array}$ \\
\hline YPFB Transporte S.A. & $\begin{array}{l}\text { Expansión Líquidos Sur } \\
\text { Asociados al GIJA }\end{array}$ & $\begin{array}{l}\text { Kaaguasu, Macharety, Alto } \\
\text { Parapeti, Kaami e lupaguasu }\end{array}$ \\
\hline Pluspetrol & $\begin{array}{l}\text { Perforación Exploratoria Pozos } \\
\text { Tacobo X-1003, Tajibo X-4 y } \\
\text { Aimiri X-1001 }\end{array}$ & Charagua Norte \\
\hline YPFB Chaco & $\begin{array}{l}\text { Perforación de 5 Pozos Campo } \\
\text { El Dorado }\end{array}$ & Takovo Mora \\
\hline
\end{tabular}

Tabela 10 - Consultas públicas realizadas em 2011 aos povos e nações indígenas. Fonte: (BOLIVIA, 2012, p. 33-34).

Por mais problemas e conflitos que geram o entendimento concreto nos pontos da consulta, cabe destacar a importância dessa iniciativa no que tange a consubstanciação do respeito às normas e convenções internacionais, as quais preveem a autonomia dos povos, como a Convenção 169 da OIT. Esse é um caminho passível de aperfeiçoamento, porém constitui uma etapa importante no processo de reconhecimento territorial e autonômico dos povos.

Um caso emblemático, que não será tratado com detalhes devido ao grau de complexidade e elementos que apresenta, é o de TIPNIS - Território Indígena Parque Nacional Isiboro-Sécure -. A proposta do governo prevê a construção de uma estrada dentro do parque nacional. Na realização da consulta pública em 2013, estabeleceram-se no protocolo da consulta, 69 comunidades. Desse total, 11 optaram por não participar e das 58 que participaram, 55 comunidades (82\%) optaram pela construção da rodovia. De toda forma, cabe salientar que alguns procedimentos da consulta foram questionados por lideranças indígenas (GÓMEZ VELA, 2013). Logo, observa- 
se uma necessidade de tratar essas questões relacionadas às consultas de uma forma mais rigorosa para que os questionamentos de parte das comunidades não comprometam a legitimidade do processo.

Além dos processos de consulta relativos aos impactos nas comunidades e aos procedimentos para avanço autonômico desde a perspectiva indígena originária, cabe ressaltar, também, a aprovação de Estatutos autonômicos departamentais, regionais e municipais. Concretamente, as autonomias departamentais interessavam diretamente às elites oligárquicas bolivianas, visto que ao perderam o poder central, tendem a inflar mecanismos que permitam a perpetuação de poder dos mesmos em âmbito regional. Contudo, as competências autonômicas possuem limitações concretas ${ }^{208}$ devendo se adaptar à Constituição de 2009, a qual cria dificuldades à reconstrução hegemônica dessas elites a nível nacional.

Como bem afirma Tapia (2009b, p. 178),

Aquí resulta evidente que mientras la línea central de la articulación de la forma primordial transita hoy por la vía de la nacionalización, la autonomía departamental trata de crear las condiciones jurídico-institucionales para hacer posible la transnacionalización fragmentaria del país; es decir, crear las condiciones para enclaves transnacionales en el contexto de un país que está caminando hacia la recuperación de sus territorios y sus recursos. En este sentido, la autonomía departamental no sólo es una estrategia de las oligarquías terratenientes y burguesas de varias regiones del país, sino que también es la estrategia del capital transnacional en un territorio donde sus agentes han perdido el poder político en el seno de las instituciones liberales de la competencia política a nivel nacional.

Os departamentos como Santa Cruz, Beni, Tarija e Pando já aprovaram, em distintas datas, suas respectivas normas departamentais para 0 reconhecimento do Estatuto autonômico, antes mesmo da promulgação da

\footnotetext{
208 Por exemplo, na arrecadação dos hidrocarbonetos, os Departamentos produtores não poderão ficar com mais de $11 \%$ da receita decorrente da extração em seu território, conforme dispositivo constitucional posto no artigo 368. Por mais que ainda gere um desequilíbrio de receitas entre os Departamentos, aqueles que forem produtores não poderão extrapolar esses limites.
} 
nova Constituição. Ainda faltam seguir alguns procedimentos para a admissão completa do Estatuto, como adequação constitucional e aprovação pelo Tribunal Constitucional Plurinacional antes de ser referendado ${ }^{209}$.

Esse tipo de ação do Estado, ao garantir o desenvolvimento autonômico e ao aprimorar os mecanismos do seu exercício, juntamente com o fortalecimento do Estado central para o direcionamento de questões estratégicas, tendem a robustecer o controle cidadão sobre o poder. Dificuldades para efetivar isso são reais, visto a relação existente com os Departamentos. Contudo, a construção política autonômica ousa avançar nessa seara sem perder de vista a manutenção de uma hegemonia política pautada em um projeto popular plurinacional.

\subsection{Os aspectos jurisdicionais conflitivos na Bolívia atual.}

3.4.1. O largo caminho para o aperfeiçoamento e aplicação da jurisdição indígena originária campesina.

Os aspectos inovadores da Constituição também atravessam o sistema democrático e de justiça boliviano. A análise de alguns elementos permite visualizar modificações importantes para a construção desse Estado Plurinacional nesses setores. O momento político atual, não permite um olhar

\footnotetext{
${ }^{209}$ Para Xavier Albó (2008), os artigos considerados difíceis e mais conflituosos, são mínimos nos estatutos de Tarija e Pando, razoáveis nos do Beni e maiores, somente no caso do Departamento de Santa Cruz. Ademais, ele salienta que das 40 novas competências departamentais exclusivas, 13 já haviam sido contempladas pela nova Constituição. Também seguem em andamento os processos estatutários de Chuquisaca, La Paz, Cochabamba, Oruro e Potosí já concebidos a luz da Constituição de 2009.
} 
para a Bolívia a partir da mera reprodução do constitucionalismo liberal, desde uma perspectiva monocultural e uninacional.

Conforme Garcia Linera,

Aún en poder de las antiguas fuerzas conservadoras, el Poder Judicial es la síntesis suprema de la corrupción como norma institucionalizada y del dogmatismo neoliberal como lógica discursiva, lo que permite todavía la persistencia y reproducción de núcleos conservadores en el Estado. La aplicación de la Nueva Constitución Política del Estado y la rerestructuración de las instituciones, a partir de las nuevas leyes que serán aprobadas en el nuevo Parlamento, denominado Nueva Asamblea Legislativa Plurinacional, nos mostrarán posibles avances en este campo, que quedan por ser interpretadas (2010a, p.28).

Dentre as questões mais complexas dessa temática está a autoridade para julgar os/as indígenas. O debate que garantia que as autoridades indígenas originárias campesinas podiam julgar qualquer tipo de matéria, com competência para conhecer todo tipo de relação jurídica, não logrou êxito na redação final da Constituição de 2009. Contudo, a jurisdição indígena originária campesina está amparada por garantias constitucionais e a uma construção institucional que permite avanços no exercício de suas competências.

Assim, as autoridades responsáveis pelos julgamentos possuem 0 mandato, amparado na Constituição, para o exercício da atividade em suas respectivas comunidades, aplicando os princípios e as garantias fundamentais em um juízo de um Estado de Direito Plurinacional Comunitário.

Nesse sentido, Idón Chivi Vargas enuncia os princípios materiais e formais, que, segundo ele, devem amparar as decisões nesses julgados. 


\begin{tabular}{|c|c|}
\hline $\begin{array}{r}\text { Jurisdicción Indígena } \\
\text { Principios Rectores emergentes d }\end{array}$ & $\begin{array}{l}\text { Originaria Campesina } \\
\text { el "Bloque de Constitucionalidad" }\end{array}$ \\
\hline PRINCIPIOS MATERIALES & PRINCIPIOS FORMALES \\
\hline $\begin{array}{l}\text { De legalidad } \\
\text { De irretroactividad } \\
\text { De mínima intervención } \\
\text { De protección de bienes jurídicos } \\
\text { De racionalidad de las penas } \\
\text { De culpabilidad } \\
\text { De proporcionalidad de la pena } \\
\text { De primacía de los Derechos Humanos, del } \\
\text { Derecho Internacional Humanitario y los } \\
\text { principios constitucionales. } \\
\text { De protección a la víctima } \\
\text { De respuesta razonable y en base a la dignidad } \\
\text { humana. } \\
\text { De interculturalidad como condición de iguales }\end{array}$ & $\begin{array}{l}\text { Debido proceso } \\
\text { o Derecho a ser juzgado por tribunales } \\
\text { competentes, independientes e imparciales } \\
\text { o Presunción de inocencia } \\
\text { \& Derecho a la defensa y la asistencia letrada } \\
\text { o Derecho a ser informado (motivo de la } \\
\text { detención) } \\
\text { o Derecho al Habeas Corpus } \\
\text { Garantía Jurisdiccional, principio de } \\
\text { juicio legal o principio de } \\
\text { jurisdiccionalidad (la autoridad } \\
\text { indígena originaria campesina) } \\
\text { Garantía de ejecución o principio de } \\
\text { ejecución legal de la pena. } \\
\text { Garantía de cooperación y coordinación } \\
\text { jurisdiccional. }\end{array}$ \\
\hline
\end{tabular}

Tabela 11 - Princípios regentes emergentes do bloco de constitucionalidade. Fonte: (CHIVI VARGAS, 2009b, p. 40).

Assim, segundo o autor citado, o procedimento jurisdicional indígena originário campesino estará sujeito ao cumprimento destes princípios, de acordo com o bloco de constitucionalidade, mesmo que seja permitido julgar a partir de seus princípios, normas, valores culturais e procedimentos próprios. $\mathrm{O}$ processo permitirá que as controvérsias possam ser solucionadas nos territórios comunitários a partir das vivências comunitárias e respeitando alguns padrões que não destoem das previsões constitucionais.

A lei de demarcação jurisdicional (Lei n 073 de 29 de dezembro de 2010) trata de regular as questões dispostas na Constituição Política do Estado entre a jurisdição indígena originária campesina e as outras jurisdições reconhecidas constitucionalmente. A partir daí fixará as possibilidades de cooperação entre as mesmas desde os marcos do pluralismo jurídico. De acordo com a lei citada, a jurisdição indígena originária campesina gozará da mesma hierarquia que as outras jurisdições (ordinária, agroambiental e as 
demais reconhecidas legalmente $)^{210}$, e as decisões tomadas dentro de sua jurisdição não podem ser revistas pelas outras jurisdições. Somente, o Tribunal Constitucional Plurinacional poderá conhecer e reformar as decisões decorrentes da jurisdição indígena originário campesina, conforme dispõe o artigo 202 da Constituição. De acordo com Farit Rojas (2013), o sistema de justiça ordinária deve ter o mesmo peso que o sistema de justiça indígena, no debate jurídico, e este último não deve subsumir-se ao primeiro.

No andamento da lide, o estabelecimento do contraditório e da ampla defesa é fundamental para o encaminhamento de uma decisão justa ao longo do processo. Contudo, de acordo com relatos citados na sequência, algumas comunidades, após a sentença condenatória, optam em estabelecer penas tais como chicotadas em praça pública entre outras mais ultrajantes.

Nesse momento, caberia sopesar até que ponto uma pena que estabelece cinquenta chicotadas seria pior do que outra que cerceia a liberdade de uma pessoa por alguns anos. Também seria importante chamar a atenção, no caso, pois a intenção não é a de reproduzir automaticamente a experiência, a partir da visão ocidental e rejeitar os tipos de sanções próprias de algumas comunidades indígenas; mas sim, observar, a partir da situação concreta, até que ponto essas sentenças realizam a justiça e não estariam reproduzindo a perpetuação de opressões históricas.

Alguns juristas consideram que esse tipo de sanção não poderia ser permitida nas comunidades, ${ }^{211}$ uma vez que violaria princípios humanos fundamentais. Da mesma forma, pode ser dada outra interpretação para essas

\footnotetext{
${ }^{210}$ Dentre os princípios que guiam as jurisdições, elencados no artigo $4^{\circ}$ da Lei $n^{\circ} 073$ de 29 de dezembro de 2010 estão os seguintes, os quais cabem ser destacados: Respeito a unidade e integridade do Estado Plurinacional; relação espiritual entre as nações e povos indígenas originários campesinos e a Mãe Terra; diversidade cultural; interpretação cultural; pluralismo jurídico com igualdade hierárquica; complementariedade; independência; equidade e igualdade de gênero e igualdade de oportunidades.

211 "Existe un régimen jurídico internacional de prohibición absoluta de todas las formas de tortura, tanto física como psicológica, régimen que pertenece hoy día al dominio del ius cogens. La prohibición absoluta de la tortura es completa e inderogable aún en las circunstancias mas difíciles tales como la guerra, amenaza de guerra, lucha con el terrorismo y cualesquiera otros delitos, estado de sitio o de emergencia, conmoción o conflicto exterior, suspensión de garantías constitucionales, inestabilidad política interna u otras emergencias o calamidades públicas" (ALBANESE, 2008, p. 20). Decisões da Corte IDH. Caso Tibi c. Equador. 7 set. 2004. p 143; caso dos irmãos Gómez Paquiyauri. p. 112; caso Maritza Urrutia, p. 92.
} 
sanções, garantindo-as como legitimas, porque respeitam a auto-organização das comunidades ${ }^{212}$.

Por mais que a lei de demarcação jurisdicional proíba qualquer tipo de linchamento, violência contra crianças, adolescentes ou mulheres e a pena de morte ${ }^{213}$; o Estado ainda não possui instrumentos de verificação eficientes para observar se, de fato, essas questões são cumpridas nas várias áreas de funcionamento da jurisdição indígena originária campesina.

Cabe destacar, que ao longo do aprimoramento dessas instituições, os meios de comunicação "satanizaram" as decisões da justiça indígena por ter ocorrido situações de justiça privada exercidas com violência. De acordo com Boaventura de Sousa Santos, as próprias autoridades indígenas denunciam essas práticas, como não sendo decorrentes de ações da justiça indígena, pois esta, por sobre tudo, pauta-se pela reintegração social e reparação do dano (2010, p. 100).

Contudo, na prática, ainda há a ocorrência de penas caracterizadas pela agressão física e psíquica dos condenados/as. Para além das chicotadas, algumas possuem uma conotação sexista por parte das autoridades julgadoras, que em nome da tradição reproduzem opressões históricas. Alguns casos foram relatados na Conferência em La Paz, sobre os 40 anos do Manifesto de Tiwanaku ${ }^{214}$. Uma das expositoras, Marina $\mathrm{Ali}^{215}$, contou um caso ocorrido no município de Apolo, no noroeste boliviano, em que uma menina adolescente após engravidar e sofrer todo o tipo de rejeição na comunidade e na escola teve o feto de cinco meses de gestação arrancado e queimado em

\footnotetext{
${ }^{212}$ Reportagem que levam em consideração a auto-organização comunitária e trata dos casos considerados linchamentos por alguns e por outra parte da comunidade local, a mera reprodução de antigas tradições. Cf. (AYALA UGARTE; DERPIC, 2013).

${ }^{213}$ Artigos $5^{\circ}$ e $6^{\circ}$ da Lei n 073 de 29 de dezembro de 2010.

214 Essa conferência ocorreu no dia 30 de Julho de 2013, no Museu de etnografia e cultura MUSEF, em La Paz - Bolívia.

${ }^{215}$ Comunicadora social e professora da UMSA - Universidad Mayor de San Andrés.
} 
praça pública como pena ${ }^{216}$. Outra adolescente, ao passar por situação semelhante após engravidar, não suportou a pressão da comunidade e suicidou-se. O viés sexista torna-se evidente, uma vez que o homem, também responsável pela gravidez, não sofreu os mesmos danos que a mulher.

Caso confirmado esse tipo de situação em julgamentos relacionados à jurisdição indígena originária campesina, cabe questionar até onde vai a autodeterminação dessas comunidades. De antemão, fica claro o desrespeito à legislação ordinária e à própria Constituição, que proíbem esse tipo pena. Além do mais, resta evidente que, tanto o machismo herdado na sociedade com a influência eurocêntrica, quanto o sexismo existente em algumas comunidades onde reina a cosmovisão indígena, podem desencadear situações de opressão, as quais devem ser trabalhadas para que esse tipo de costume seja revisto e a sociedade, de fato, transformada ${ }^{217}$.

Um raciocínio similar deve tratar de casos que, eventualmente, são apenados com linchamentos, e que podem, inclusive, levar a morte do apenado. Tapia chama a atenção para um aspecto importante ao apontar que uma "justiça comunitária não necessariamente é democrática, a não ser que contenha, não só o princípio da igualdade, mas a possibilidade e o direito de exercer a liberdade política para questionar as normas coletivas que implica" (tradução livre) (2009b, p. 161-162). Nesse caso, a busca por justiça enunciase no exercício democrático de questionamento da norma e real possibilidade de revisão desta.

Nenhuma manutenção de costumes justifica a retirada da vida humana como pena imposta, mesmo que a valoração da vida varie de um povo para o outro, seja nas comunidades indígenas ou até mesmo em países considerados "desenvolvidos" como os Estados Unidos, e que aceitam a pena de morte sem grandes questionamentos. Ao analisar o conjunto de rupturas, avanços sociais

\footnotetext{
${ }^{216}$ Essa informação pode ser acessada em notícias dos jornais bolivianos que estão na internet. Disponível em http://www.fmbolivia.net/noticia61487-embarazada-en-apolo-fuegolpeada-y-abort.html. Acesso: 09 abr. 2014.

217 "¿Cómo es la "barriga de sapo"? Fría. Para el gaucho la mujer se le aparecía fría; porque el oprimido, de tanto pasar de mano en mano, al fin se vuelve indiferente al dominador; es cosa poseída, pero no es persona dignamente amada"(DUSSEL, 1990, p. 20) .
} 
e plurinacionais concebido pelo Estado Plurinacional da Bolívia, resta evidente que este projeto político-jurídico construído não sustentaria qualquer princípio violador da vida.

Idón Chivi Vargas (2009b, p. 41) problematiza, também, outras questões e considera que a jurisdição indígena originaria campesina não poderia violar os princípios materiais da legalidade e da irretroatividade já que todos os órgãos do Estado estão submetidos a esses princípios basilares para o exercício jurisdicional; nesse sentido, afirma Vargas, seu desrespeito não poderia ser justificado nem sequer em nome de uma interpretação intercultural.

Assim, uma vez que a Constituição estabeleceu um pacto social, alguns acordos devem ser respeitados, não permitindo que grupos específicos exacerbem algo construído em conjunto para fazer valer sua própria vontade. Abrir exceções ao funcionamento das jurisdições indígenas originárias campesinas poderia abrir precedentes para além desses grupos e possibilitar, inclusive, abusos de autoridade dentro das próprias comunidades.

3.4.2. A formação do Tribunal Constitucional Plurinacional e as eleições no sistema de justiça boliviano.

Quanto ao Tribunal Constitucional Plurinacional, formado por representantes do sistema ordinário e indígena originário campesino, este terá o condão de abarcar todas as jurisdições e institucionalidades indígenas e formais, conformando uma jurisdição constitucional intercultural que parta da plurinacionalidade existente. Ele é responsável por garantir o controle de constitucionalidade das normas, o controle do exercício do poder público e o cumprimento da Constituição assegurando direitos e liberdades aos povos, comunidades e aos indivíduos bolivianos/as. 
Assim, uma vez inspirado nas aspirações e possibilidades do novo constitucionalismo latino-americano, o Tribunal Constitucional Plurinacional não deve restringir-se a reproduzir jurisprudências, mas criá-las a partir das condições objetivas e princípios interculturais postos nesse novo momento político boliviano.

O que chama a atenção no sistema de justiça da Bolívia é a eleição aberta, através do voto direto e individual dos cidadãos/ãs maiores de 18 anos, para os órgãos de Justiça, mais especificamente para o Tribunal Agroambiental, o Conselho da Magistratura, o Tribunal Constitucional Plurinacional e o Tribunal Supremo de Justiça. A eleição mais recente ocorreu em 16 de outubro de 2011 tendo sido a primeira ocorrida na história da Bolívia.

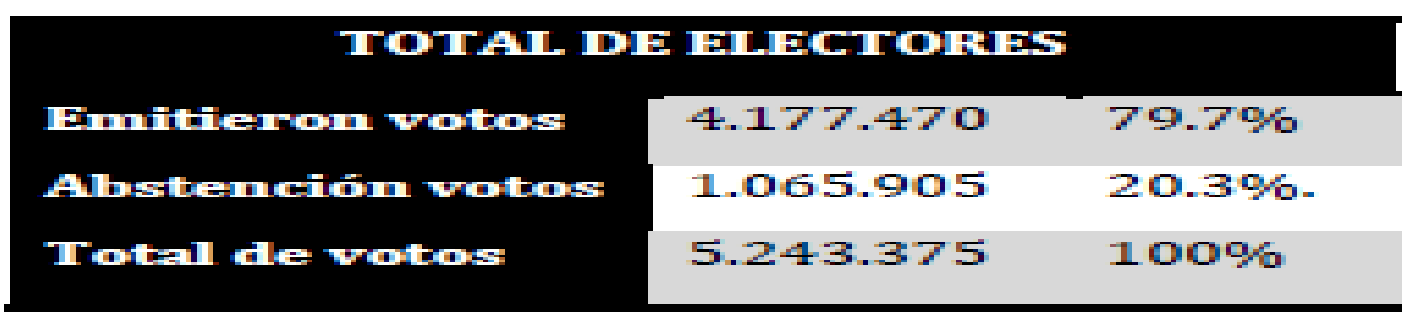

Tabela 12 - Porcentagem de votos nas eleições para os órgãos de Justiça na Bolívia. Fonte: (LORENZO G., 2011, p. 4).

Quase $80 \%$ dos eleitores bolivianos emitiram votos, mesmo tendo grande porcentagem desses, sido de votos brancos e nulos. Muito em decorrência de falta de informação, por ser a primeira eleição e devido à campanha contrária às eleições desse tipo, realizada pela oposição; por outro lado, outra questão que gerou confusão foi o fato da cédula eleitoral conter mais de 115 postulantes para os distintos órgãos judiciais, o que confundiu 0 eleitorado (LORENZO G., 2011, p. 5). Assim, os candidatos/as, de uma forma geral, obtiveram porcentagens baixas de votos e foram homologados/as como autoridades judiciais ${ }^{218}$. Esse processo eleitoral tende a avançar nos próximos pleitos, devendo ser aperfeiçoados alguns mecanismos formais para que as

${ }^{218}$ ANEXO M - Autoridades Judiciais eleitas no sufrágio de 2011. 
autoridades eleitas representem os anseios de justiça diante das expectativas populares.

Observa-se uma mescla de alguns elementos liberais já existentes com novos elementos trazidos por outros grupos sociais, como os indígenas, os quais caminham para uma descolonização da análise jurisdicional.

Nesse sentido, conforme afirma Mota (2009, p. 148):

Em relação ao Judiciário, especialmente no Título reservado ao "Órgão Judicial e Tribunal Constitucional Plurinacional", podemos ver no Artigo 178, lado a lado com os princípios liberais de independência, imparcialidade e publicidade, a entrada das ideias de pluralismo jurídico e interculturalidade como pontos que passam a determinar o sistema jurídico do país. Embora a função judicial permaneça sendo única - como dispõe o Artigo 181, no qual o Tribunal Supremo de Justiça aparece como instância máxima e o órgão judicial responsável pela jurisdição ordinária -, a execução da jurisdição indígena originária camponesa por meio de suas próprias autoridades também passa a ser admitida no novo texto. Porém, a subordinação da jurisdição originária aos demais direitos e garantias estabelecidos na Constituição está assegurado no Artigo 190.

Como todo processo, o sistema eleitoral para juízes da Bolívia não é algo acabado; ele apresenta falhas e problemas ao deparar-se com os inúmeros vetores trazidos pela realidade; por outro lado, contem mecanismos de maior participação popular no processo de construção do sistema de justiça. Ademais, hoje em dia, a jurisdição indígena originária campesina é parte do órgão Judicial do país, e isso implica no respeito aos princípios estabelecidos e à própria Constituição Política do Estado Plurinacional boliviano.

\subsection{A democracia a partir de uma nova institucionalidade.}


3.5.1. O fortalecimento de uma legitimidade democrática para acabar com a cultura dos Golpes de Estado.

A relação da Bolívia com a democracia sempre foi delicada ao longo da história. O país é reconhecidamente um "campeão" em Golpes de Estado, pois desde a independência em 1825 ocorreram aproximadamente 150 tomadas de poder não constitucionais, nem todas com êxito duradouro. A instabilidade política apresentava o frágil lastro democrático do país, além de destacar a força de ingerência da elite interna e internacional.

O desenvolvimento de um regime democrático, amparado pelo modo de produção capitalista dependente e em práticas políticas coloniais, como ocorre na América Latina como um todo, garantia maior facilidade de intervenções imperialistas na realidade política econômica da Bolívia.

Como bem afirma Tapia:

En este sentido, una redefinición geopolítica de la democracia en su núcleo, implica acompañarla de estrategias de desmontaje del imperialismo y, también, del capitalismo en lo internacional y en lo nacional. El capitalismo es el tipo de régimen económico o modo de producción que históricamente produce la tendencia al monopolio económico en lo interno, que luego se vuelve monopolio transnacional a través de políticas coloniales e imperialistas y, por lo tanto, son la condición material de cancelación y reducción de los grados de autogobierno para la mayor parte de las sociedades y países en el mundo. En este sentido, hay va a haber una fuerte tensión entre capitalismo y democracia (2009a, p. 91).

A luta por mais democracia na Bolívia representa também a busca pelo estabelecimento de um novo modo de produção e pela descolonização do funcionamento do Estado. A mera reprodução da lógica democrática modernaocidental é insuficiente para as rupturas propostas pelo Estado Plurinacional 
Comunitário. Alguns instrumentos são importantes para, em um primeiro momento, inviabilizar as tentativas frequentes de Golpes de Estado e na sequência, construir alternativas democráticas que contribuam para alcançar os objetivos propostos, que estão muito além do que somente eleger representantes ${ }^{219}$.

A cultura política dos golpes continuou na Bolívia, mesmo com a estabilidade alcançada após a eleição de Evo Morales, mas as elites perderam a batalha mais recente em 2008. A Constituição Política do Estado fortalece mecanismos e instituições estimuladores da democracia. A criação do Poder Eleitoral é um desses exemplos, em que a estrutura do Estado é modificada com a criação de um novo poder para consolidar as escolhas do povo e dar mais seriedade aos processos eleitorais no país.

A institucionalidade concebida ampara a legitimidade do voto com maior vigor e afasta o ambiente frágil que animava os intentos golpistas insatisfeitos com os resultados eleitorais. A sedimentação da dinâmica relacionada à democracia representativa é tão só um dos aspectos renovados da democracia boliviana pós-Constituição de 2009. Como salienta Luis Tapia, "Nesse sentido, a primeira tarefa é pensar os espaços de participação antes de pensar as formas de representação" (Tradução Livre) (2007a, p. 128).

O Estado deverá garantir, como está fazendo, formas de construção interna na sua reestruturação, seja através de uma Assembleia Legislativa Plurinacional, a eleição por voto direto dos membros do Poder Judiciário, dentre os quais, a de um Tribunal Constitucional Plurinacional, ou até mesmo o reconhecimento das instâncias decisórias nos territórios e comunidades indígenas originárias campesinas.

\footnotetext{
219 "Por último, la idea central consiste en pensar geopolíticamente la democracia, no implica pensar la expansión de un modelo que, por lo general, ha estado históricamente ligado a la expansión del poder de uno o un conjunto de estados sobre el resto de la región y el mundo, sino que la introducción de la dimensión geopolítica en el núcleo definitorio de la democracia sirva para ampliar las áreas de igualdad en las relaciones intergubenamentales, interestatales e intersocietales, y para producir algunos ámbitos de cogobierno democrático" (TAPIA, 2009a, p. 93).
} 
3.5.2. A busca por uma democracia intercultural popular em um ambiente predominantemente liberal e capitalista.

A previsão constitucional de tipos democráticos que passam pela forma representativa, participativa e comunitária nos leva a considerar que, adequada à realidade boliviana, isso configuraria uma espécie de "democracia intercultural popular". A estrutura social boliviana formada majoritariamente por indígenas e mestiços componentes das classes trabalhadora, camponeses, autônomos e comunitários expõe a diversidade fundamental da dinâmica democrática atrelada à construção intercultural das várias nações estabelecidas. O reconhecimento estatal dos diversos tipos democráticos, também se dará através de uma Lei de Regime Eleitoral (Lei n’26 de 30 de junho de 2010). Assim, o exercício da democracia intercultural popular poderá referenciar-se e dinamizar-se com esse aparato legal no Estado de caráter plurinacional.

Dentre as democracias elencadas, a democracia representativa e seu sistema de escolha de representantes para atuarem diretamente nos poderes do Estado, aperfeiçoou-se com a Constituição.

Isso já ficou demonstrado no ano seguinte após a sua promulgação, como destaca Boaventura de Sousa Santos, ao chamar a atenção para as eleições e as possibilidades autonômicas.

En las elecciones departamentales y municipales de Bolivia realizadas el 4 de abril de 2010 se ha dado un paso decisivo en la construcción del Estado plurinacional a través de las autonomías departamentales, regionales, municipales e indígenas. Se eligieron por primera vez gobernadores y asambleas departamentales, además de la elección de alcaldes y concejales municipales. El carácter plurinacional del Estado estuvo expresado en la elección directa de 23 
asambleístas departamentales de las naciones y pueblos indígena originario campesinos que son minoría poblacional en los respectivos departamentos del país (2010, p. 103-104).

A democracia participativa estabelece a participação ativa e direta dos indivíduos em pleitos políticos pautados na sociedade. Ela consiste em uma forma de ação direcionada à vivência e, às vezes, gestão concreta da coisa pública. No entanto, tal qual a representativa, constitui-se por uma relação entre indivíduos.

Já a democracia comunitária será concebida desde uma relação do indivíduo com a comunidade e, atrelado a isso, sua relação com a pachamama. Ou seja, existe outra construção da relação política onde prima a necessidade coletiva ou comunitária frente à vontade do indivíduo. Por mais que tenha garantias gerais para que possa funcionar, as diversas nações e povos indígenas utilizarão de formas, normas e procedimentos próprios e adequados aos seus costumes.

As consolidações das autonomias indígena originária campesinas tendem a fortalecer a prática da democracia comunitária, algo que dinamizará essa perspectiva de democracia intercultural popular na Bolívia. Contudo, esse tipo democrático deve ser estimulado juntamente com o modo de produção não capitalista, através da forma comunal naquele espaço, viabilizando uma construção comunitária-popular, de fato, sustentável, com consciência crítica e não colonial.

A través de la democracia se puede reducir la separación entre gobernantes y gobernados y a través de una forma comunitaria se puede enfrentar la separación entre sociedad y naturaleza, ya que es la forma política que responde a una temporalidad agraria que sigue los ciclos de la naturaleza. Para esto no es suficiente la forma política sino también la existencia de modos de producción no capitalistas, que permitan sostener una vida política democrática y la complementariedad entre pueblos (TAPIA, 2009a, p. 44-45). 
O interessante é que o funcionamento da democracia comunitária tende a construir consensos, que influenciam inclusive nas esferas de representação do Estado. Um exemplo disso foi a eleição para a escolha do deputado representante do assento indígena na Circunscrição Especial de Beni (departamento boliviano) no ano de 2009, a disputa ficou entre duas lideranças de origem étnica mojeños. Uma era Pedro Nuni pelo MAS-IPSP e a outra era Marcial Fabriciano pela PPB Convergência. O primeiro teve um apoio orgânico e massivo dos indígenas locais, enquanto o segundo teve a campanha impulsionada pela elite política tradicional de Beni. A construção de consensos dentro da dinâmica da democracia comunitária possibilitou um direcionamento massivo e contundente na eleição do dirigente, àquela época, do MAS-IPSP com $75 \%$ dos votos (GUZMÁN, 2009).

Mesmo assim, a forma democrática boliviana possui suas distorções. $\mathrm{Na}$ eleição para a Câmara dos Deputados no ano de 2009, regida pela lei eleitoral transitória $\mathrm{n}^{\circ} 4021^{220}$, as nações indígenas poderiam eleger um representante por departamento. Isso quer dizer, como bem lembrou Albert Noguera, que os diversos povos e nações indígenas localizados, por exemplo, no "departamento de Tarija (povos Guaraní, Weenayek e Tapiete), por exemplo, elegeriam um representante comum departamental que representará os indígenas do departamento" (tradução livre). (2010, p. 98). Isso valeu para os outros povos localizados em seus respectivos departamentos, exceto Chuquisaca e Potosí que não tiveram representantes indígenas na Câmara. Assim, observa-se, uma vez mais, que a representação territorial é feita por departamentos e não pelo próprio território em si. Logo, fica demonstrada a não superação da lógica liberal, pois a representação subordina-se, de alguma forma, ao ente estatal.

No entanto, há uma conjuntura e uma criação de ambientes políticos que estimulam mudanças, as quais atravessam a colonialidade do poder estabelecida na história da Bolívia. Busca-se "superar a velha tradição de

\footnotetext{
${ }^{220}$ Essa lei foi aprovada em 14 de abril de 2009, e regula o procedimento, desenvolvimento, vigilância e controle do processo eleitoral para a constituição da Assembleia Legislativa Plurinacional, eleição da presidenta ou presidente, vicepresidenta ou vicepresidente e autoridades departamentais e municipais nas eleições de dezembro de 2009 e abril de 2010.
} 
democracia representativa, se melhoram os mecanismos institucionais da democracia participativa e se constrói alicerces para a democracia igualitária" (Tradução Livre) (CHIVI VARGAS, 2009a, p. 62). A construção de uma democracia igualitária que enfrenta os problemas relacionados à história colonial e o capitalismo dependente deve ser visto como um passo qualitativo superior da construção democrática. A Constituição Política do Estado Plurinacional abre uma janela histórica para se enfrentar essa questão e permite a construção de uma nova perspectiva de democracia.

\subsection{A Constituição Plurinacional e o Estado de Transição: o socialismo comunitário no horizonte.}

O novo cenário político da Bolívia apresenta instituições que não repetem automaticamente as formas construídas desde uma gênese liberal e eurocêntrica. Ela opta por impulsionar diferenciadas condições de desenvolvimento, mesmo que ainda incorporada pela zona de influência do capitalismo e com aspectos politico-jurídicos ainda liberais. Conforme surgem as necessidades populares, e se coloca a urgência tática de sanar essas necessidades, o processo revolucionário se vê obrigado a procurar saídas e criar mecanismos para suprimi-las (CHIVI VARGAS, 2013).

Nesses termos e diante das condições objetivas postas na seara política e econômica, a Constituição contribui para legitimar e garantir as mudanças possíveis e passíveis de realização. Ela auxilia a consumação de um rompimento com o contexto neoliberal vigente anterior e direciona para uma perspectiva que tenta unir o fortalecimento do Estado concomitante às formas comunitárias. Verifica-se que esse robustecimento ocorre em graus diferentes, onde se prioriza o Estado nesse período inicial enquanto as ações ligadas às mudanças autonômicas estão mais lentas, apesar de ocorrerem. 
Aparentemente, o que se depreende desse movimento é o intento de manutenção de hegemonia política do bloco indígena-popular no Estado, mesmo com algumas fraturas, frente às ingerências político-econômicas, sobretudo, externas.

A Bolívia busca formas de evitar uma maior vulnerabilidade diante das ações econômicas e políticas, as quais ao longo da história foram centrais para a sua desestabilização. Por outro lado, a contínua consolidação de um projeto democrático e popular no país tende a criar condições para a aceleração dos processos autonômicos indígena originário campesinos, quando constituírem um pleito da comunidade.

Eduardo Paz Rada (2013) salienta que, o caminho às sociedades socialistas passa pela derrocada do capitalismo ou até mesmo por recuperar formas pré-capitalistas, como as formas comunitárias. No entanto, ele pensa que a forma comunitária ainda é muito marginal na Bolívia e não configuraria uma opção real de projeto que englobaria todo o país. Assim, por meio da leitura de Paz Rada, consideramos que uma frente político-econômica desenvolve-se a partir das contradições capitalistas e por outro lado estimulase a dinâmica das formas comunitárias como uma das alternativas já praticadas na Bolívia.

Logo, nos parece ser possível conceber a nova Constituição Política do Estado boliviano, fomentada pela analética social do direito aqui tratada ${ }^{221}$, como uma Constituição que transita entre o Estado Unitário, republicano assentado no neoliberalismo a um Estado Plurinacional. Isso, porque nota-se a priorização de suas características indígenas e populares na incorporação da estrutura e institucionalidade própria ao desenvolvimento das nações e povos indígenas, camponeses e, até certo ponto, dos trabalhadores/as. Contudo, os aspectos liberais ainda estão presentes a essa construção plurinacional. Algo que reforça o caráter dessa transição jurídico-política da Constituição e, consequentemente, do Estado.

\footnotetext{
${ }^{221}$ Ver Capítulo 2, ponto 2.2.3.
} 
A prática política transitória é verificada em diversos momentos no decorrer da história ${ }^{222}$, além de consistir em um elemento que ajuda na compreensão da teoria política revolucionária. Não por acaso, Marx distingue esse período de transição ao destacar a ditadura do proletariado como uma fase do processo revolucionário até o alcance, de fato, do comunismo (MARX, 2012b). Ao longo desse período, a dinâmica estatal ainda se valerá de um cabedal jurídico burguês, pois essa fase a que Marx se refere, conhecida por socialista, ainda subsiste o trabalho ${ }^{223}$ como medida social decorrente da própria divisão do trabalho ainda estabelecida. Algo, que no comunismo não mais ocorrerá.

A situação boliviana remete a momentos históricos, tratados no decorrer da tese, os quais apresentam um trajeto próprio. Primeiramente, há uma crise estatal do projeto neoliberal passando pela consolidação de outro projeto político, por meio de um novo bloco histórico, que assume a direção politica do Estado e a consolida ao ter êxito no momento de maior enfrentamento frente ao bloco antagônico. Daí em diante, as ações de um governo de ruptura, sobretudo após a promulgação da Constituição em 2009, apresentam o delineamento da transição do Estado. Trata-se de um Estado que se reestrutura e consolida como Plurinacional. Diante da disputa de hegemonias na Bolívia, conforme destaca Rodrigo Santaella, resta claro que nesse momento histórico, "[...] o horizonte estratégico não era socialista ou comunista [...], mas sim radicalmente democratizante e descolonizador" (2013, p. 230).

Os rumos da política travada pelo governo e estimulada pela Constituição são compreensíveis quando se observa a impossibilidade de rompimento imediato com o modo de produção estabelecido. Assim, a

\footnotetext{
222 “(...) intentemos acercarnos ahora a algunos elementos del Estado en transición o momentos de revolución política de las sociedades. Para ello, son reveladores los textos de Robespierre, también los de Marx en los que escribe sobre la revolución europea de 1848-1850 y sobre la Comuna de Paris en 1871, al igual que las reflexiones de Lenin en el periodo 19181920 y, por supuesto, René Zavaleta Mercado cuando estudia la revolución de 1952" (GARCIA LINERA, 2010b, p. 11).

${ }^{223} \mathrm{Em}$ uma fase anterior ao socialismo, tal qual vivemos hoje no capitalismo, o padrão de medida estabelecido na sociedade é o valor da mercadoria.
} 
nacionalização de recursos naturais e consequente industrialização dos mesmos são fundamentais, nesse momento, para a expansão econômica do país. Isso irá requerer mais dinheiro para investimento e, também, algum tempo para a realização mais ampla dessa política. Contudo, as formas de consolidação desse processo devem sempre atentar-se para ações que não comprometam sua orientação para a mera reprodução de um capitalismo neoextrativista. Atualmente, as dificuldades que o Estado boliviano tem são outras nessa mudança de direcionamento, como a falta de profissionais capacitados para atuar nas empresas públicas, visto que o nível salarial na iniciativa privada é muito alto e atrai os profissionais; além da formação prévia dos mesmos ser voltada para o setor privado e não para o público.

O Estado Plurinacional, através das nacionalizações e do processo de industrialização, gera valor por meio da renda desses empreendimentos que não mais é direcionada aos setores privados. O excedente produzido é redistribuído entre os setores sociais ${ }^{224}$ mais vulneráveis, os quais são priorizados as necessidades do povo e o valor de uso frente ao valor de troca e ao lucro dos mercados. A contradição inerente a esse processo de industrialização e a essa geração de valor de uso é o impacto ambiental causado, que afeta, ainda que indiretamente, o ser humano. No entanto, ainda assim, não se compara à lógica capitalista, que na ânsia do lucro imediato e a qualquer custo, produz valor de troca ignorando ou somente camuflando a real destruição provocada à natureza.

As formas comunitárias, como já destacado, indicam outra forma social de estabelecimento das forças produtivas, em que o papel da natureza integrado ao desenvolvimento humano são as molas propulsoras e criadoras da organização social. Nesse sentido, Álvaro Garcia Linera equipara essa

\footnotetext{
224 "El acceso al agua está subvencionada, lo mismo el crédito a los pequeños productores, y el Estado también compra productos agrícolas para garantizar soberanía alimentaria y su venta a precio justo. En ese caso, los precios para que los consumidores accedan a esos productos no se regulan por su valor-mercantil capitalista sino por su valor de uso. Entonces el Estado, a través del excedente generado en la industrialización, comienza a desprenderse gradualmente de la lógica capitalista de la apropiación privada como norma económica e introduce expansivamente la lógica del valor de uso, de la satisfacción de necesidades, de fundamento comunitario y comunista, como principio rector de actividades económicas" (GARCIA LINERA, 2012a, p. 67).
} 
forma comunitária ao comunismo, trazendo uma releitura de Marx ao contexto boliviano e apontando a possibilidade de construção de um socialismo comunitário.

Conforme Garcia Linera:

A eso le llamaba Marx el comunismo, la realización de la lógica total del "valor de uso" de la naturaleza en el ser humano y del ser humano realizado en la naturaleza. En eso consiste el Vivir Bien: en utilizar la ciencia, la tecnología y la industria para generar riqueza, de otra manera con qué se podrían construir carreteras, levantar postas sanitarias, escuelas, producir alimentos, satisfacer las necesidades básicas y crecientes de la sociedad. Necesitamos industrializarnos pero también cuidar la naturaleza y preservarla para los siguientes siglos. El capitalismo la depreda, la destruye, la utiliza con fines de lucro y no para la satisfacción de las necesidades. Esta tensión creativa es la que el Presidente Evo ha llamado el socialismo comunitario del vivir bien, la satisfacción de las necesidades materiales humanas mediante el diálogo vivificante con la naturaleza, preservándola para preservar también el destino y el bienestar común de las futuras generaciones de todos los seres vivos. (2012a, p. 70-71).

O fato é que, o bloco componente dessa vanguarda transformadora, composta pelos setores indígenas-campesinos-trabalhadores/as, deve enfrentar todas essas contradições internas mantendo a unidade e sem desvirtuar os princípios estratégicos do processo de ruptura. A luta política é permanente, e a emancipação popular, a partir de um socialismo comunitário, uma luz no horizonte.

No entanto, a construção de um caminho socialista não se faz somente com um ideal político. O proletariado deve aumentar numericamente e fortalecer ainda mais seu papel no processo transformador boliviano, pois é o sujeito que sofre diretamente a subsunção ao capital. Logo, ele/a terá papel importante para um giro a uma revolução pós-capitalista e sem esse sujeito não há socialismo. Junto ao proletariado segue viva a forma comunitária, que deverá ter seus laços fortalecidos, não como mero ente familiar, mas a partir de 
uma atividade produtiva e prioritária dentro do atual projeto de Estado Plurinacional. Visto que a urbanização foi um fator real nessas últimas décadas, os laços comunitários, enquanto forma organizativa, devem ser pensados, não só nos ayllus ou nas áreas rurais, mas também nos centros urbanos. Assim, poderá ocorrer um maior fluxo produtivo não direcionado somente pela demanda mercadológica, mas pelas necessidades populares.

Quanto mais o projeto político for identificado com a classe trabalhadora, e essa classe, de forma consistente e mantendo o acúmulo histórico recente, se fortalece na capacidade de dirigir o Estado, é sinal que se aproxima o momento de dar um salto do liberalismo, o qual busca omitir a classe social específica que suporta e só considera o indivíduo e uma coletividade abstrata, para o socialismo. Sendo então, essa classe trabalhadora aliada ao sujeito indígena e camponês, sujeitos coletivos concretos, os únicos capazes de alterarem o modo de produção e eliminarem a exploração capitalista na realidade boliviana.

Até o momento, parte-se de uma sociedade "abigarrada" recuperando o termo de Rene Zavaleta Mercado (2009), de matriz colonial para uma sociedade plurinacional democrática. O Estado Plurinacional é, de fato, uma aposta de caminho democrático ao socialismo comunitário. Na Bolívia está indissociavelmente fundada em pilares ligados aos setores dos trabalhadores/as e indígenas-campesinos.

Mais do que uma mudança de organização e direcionamento econômico, o socialismo comunitário afeta o paradigma civilizatório, apontando novas janelas de desenvolvimento.

Como destaca Gonzalo Gonsalvez;

El socialismo comunitario, como ha sido definido por las organizaciones y movimientos sociales, el modelo de la revolución que se lleva adelante, tiene justamente la característica de articular el transito del neoliberalismo a un modelo más social, de un tránsito del capitalismo al socialismo pero al mismo tiempo un tránsito de un sistema civilizatorio 
occidental moderno a un sistema civilizatorio distinto (GONSALVEZ, 2012, p. 175.).

trajeto rumo ao socialismo comunitário dialoga com uma perspectiva transmoderna $^{225}$ de sociedade, em que os sujeitos e grupos componentes da exterioridade, historicamente à margem das construções institucionais, tornamse protagonistas de um processo histórico. O direito e, consequentemente, a Constituição passa a ser uma correia transmissora de um novo projeto, diante de relações jurídicas que cumprem novos papéis, para além da sustentação da forma mercadoria ${ }^{226}$. No contexto atual boliviano essas projeções ainda são embrionárias, porém apontam e iniciam um caminhar nesse sentido.

Até agora, a direita não teve força para sair dos "currais" de poder em que se encontra e reorganizar um projeto nacional. Contudo, ainda é uma incógnita como se resolverão as fissuras internas do bloco indígena-popular, como destacado no emblemático conflito em TIPNIS ${ }^{227}$, e outras tensões que envolvem grupos indígenas e a relação que possuem com a "mãe terra" na contínua luta pelo vivir bien.

Ao longo do desenvolvimento desse Estado de transição será necessário a criação de mecanismos intermediários que concretizem aspectos do vivir bien, indo além das nuances retóricas e meramente místicas, que algumas vezes sustentam o conceito. Isso deve ser aliado ao projeto de

\footnotetext{
${ }^{225}$ Termo desenvolvido no ponto 2.1.2.

${ }^{226}$ Termo desenvolvido no ponto 2.2.1.

227 "EI conflicto del TIPNIS mostró varios problemas:

-Las formas a menudo bruscas con las que el gobierno busca imponer sus planes (como ya había ocurrido con el fallido gasolinazo de diciembre de 2010).

-Que es necesario avanzar en creatividad para buscar soluciones a las dificultades que se van presentando: en este caso, cómo compatibilizar la tradicional necesidad de integración física del país con los nuevos derechos de los pueblos indígenas (y de la propia naturaleza si asumimos en serio el "vivir bien") consagrados en la nueva Carta Magna.

-El hecho de que los imaginarios de consumo de los sectores populares bolivianos -por más que sean indígenas- no son demasiado diferentes a los de otros espacios plebeyo/populares del continente y del mundo.

Pero hay más: en el caso del TIPNIS, los más entusiastas impulsores de la ruta no son grupos oligárquicos (aunque algunas élites pueblerinas amazónicas y empresarios apoyan el trazado) sino los campesinos cocaleros, ahora diabolizados por varios de los defensores del "vivir bien" y por el grupo de ex funcionarios hoy críticos que reclama la reconducción del proceso de cambio" (STEFANONI, 2012, p. 5).
} 
sociedade que reforça uma estrutura plurinacional para continuar o desenvolvimento de um plano de socialismo comunitário, ou seja, deve ser reforçado seu elo classista com os trabalhadores/as em prol da reversão do modo de produção capitalista. Dessa forma, o vivir bien cumprirá uma dupla função como estimulador da superação da exploração do homem/mulher pelo homem/mulher e da "mãe" natureza pelo ser humano. Algo que terá condições de êxito a partir da solidariedade e unidade entre os outros países latinoamericanos e de outras partes do mundo ao conseguirem avançar em seus respectivos processos de ruptura frente ao modelo capitalista/colonial posto. Já ocorrem algumas importantes ações de integração na América Latina, que apontam para a superação desses problemas estruturais históricos. Dentre essas iniciativas destacam-se: a ALBA ${ }^{228}$, a Telesul ${ }^{229}$, o Banco do Sul $^{230}$ e a CELAC $^{231}$ - Comunidade dos Estados Latino-americanos e Caribenhos. Esses mecanismos e instituições criadas são importantes para a consolidação de projetos democráticos populares na América Latina.

Diante desse contexto, um quarteto elementar contribuirá para esse projeto de socialismo sui generis forjado na realidade boliviana: a plurinacionalidade (reconhecimento das variadas nações e povos), a democracia igualitária (capaz de avançar sobre a colonialidade e o capitalismo), o direcionamento do Estado em setores estratégicos (mantenedor da unidade e estimulador da pluralidade econômica) e a garantia autonômica (descentralizando parte do poder territorial).

\footnotetext{
${ }^{228}$ Um bloco formado objetivando uma maior integração social, econômica e política na América Latina, o qual busca desenvolver empreendimentos para além das atividades comerciais. Atualmente é composta por Bolívia, Venezuela, Cuba, Dominica, Equador, Nicarágua, Antigua e Barbuda, e São Vicente e Granadinas.

${ }^{229}$ Rede de televisão multi-estatal criada em uma parceria entre os governos da Venezuela, Argentina, Cuba e Uruguai. Além desses hoje também são proprietários Bolívia, Equador e Nicarágua.

${ }^{230}$ Dentre os objetivos do banco, um dos principais é emprestar dinheiro às nações da América Latina para a construção de programas sociais e de infra-estrutura.

${ }^{231}$ Esse é um mecanismo de articulação política e integração composto pelos trinta e três países da América do Sul, América Central, o Caribe, incluindo o México pela América do Norte.
} 
Para isso, o Estado e a sociedade estabelecem condições para cumprir esses compromissos, no momento que definem as linhas políticas estratégicas do Estado, consolidam as instituições e seus dispositivos para o cumprimento das políticas públicas e, por fim, reserva recursos econômicos para a execução das mesmas (VEGA CAMACHO, 2010, p. 143). Algo que segue em andamento na ativa dinâmica política boliviana.

Nesse momento, não seria possível fazer previsões sobre os rumos que esse processo de ruptura irá tomar. Ele segue por linhas democráticas e populares, apresentando contradições, porém mantendo um direcionamento político coerente diante dos desafios que estabelece e limitações que se depara. Alcançar o socialismo comunitário não é uma tarefa simples, embora a formação de um Estado Plurinacional possa ser uma alternativa factível para se atingir esse horizonte ao tratar de um país como a Bolívia. 


\section{CONSIDERAÇÕES FINAIS}

No alvorecer do século XXI, alguns países latino-americanos, sobretudo a Bolívia, atraem estudiosos/as, pesquisadores/as, militantes e curiosos estimulados pelo novo processo de luta social apresentado. De todo esse processo, a Constituição - e os efeitos decorrentes dela -, fora elencada como objeto primordial para a análise da pesquisa; não simplesmente, sua dimensão discursiva, mas real e concreta a partir dos enunciados, os quais abordam temas centrais na sociedade boliviana.

A Constituição de 2009 traz um germe de Estado Plurinacional, que enfrenta, em parte, a lógica liberal e reconhece, por exemplo, formas de autorepresentação e autogoverno ainda não completamente implementadas. No entanto, essas garantias a alguns grupos indígenas, são consideradas insuficientes em decorrência da contribuição dos mesmos no momento de formação do bloco histórico indígena-popular. Logo, não se deve cair no discurso maniqueísta que trata o Estado Plurinacional de forma idealizada e quase romântica, como portador de uma espiritualidade inerente ao seu contexto social, tampouco deve ser sustentado o discurso pragmático de que nada mudou e segue um processo de reprodução diferenciada do mesmo padrão liberal e capitalista.

O novo constitucionalismo latino-americano e, sobretudo, a própria Constituição boliviana de 2009, agem com protagonismo e servem como instrumento hegemônico de um projeto popular na Bolívia, porém não superaram completamente as estruturas históricas postas. Certamente avançaram bastante, mesmo na seara das garantias liberais, e criaram mecanismos constitucionais próprios que vão além do que a mera perspectiva liberal poderia alcançar.

As tensões apresentadas na efetivação dos enunciados constitucionais acontecem nos variados temas trabalhados, não por acaso; a luta social é dinâmica, da mesma forma que o projeto político em suas ações táticas. Assim, por mais que os princípios dessa luta sejam mantidos, as ações políticas secundárias não possuem caminho único. Os mecanismos constitucionais, por 
mais inovadores que sejam, não apresentam uma configuração homogênea no momento da concretização dos dispositivos. Temas como descolonização, plurinacionalidade, economia, vivir bien, democracia, autonomias, reforma agrária e jurisdições fazem parte de um conjunto de pilares, os quais, historicamente o Estado reproduziu uma lógica distanciada e impositiva aos povos, capaz de gerar problemas sociais fundantes. Não havia uma orientação intercultural, nem sequer descolonizadora ou anti-imperialista na estruturação institucional ou na construção de políticas públicas. O que se observava era uma estrutura enviesada e colonizada de poder, subserviente a uma dominação de grupos oligárquicos internos e externos, que regiam os instrumentos do Estado central.

Após a vitória do bloco indígena-popular, não só com a eleição de Evo Morales em 2005, mas também com o triunfo desse bloco após a tentativa de Golpe em 2008, consolida-se hegemonicamente um novo projeto de poder. Esse, uma vez materializado na Constituição Política do Estado Plurinacional, apresenta, de fato, algumas tensões na concretização dos seus enunciados. No entanto, os conflitos recentes gerados, principalmente após esse período de 2008, dentro do próprio bloco histórico, estão em outro patamar se comparados às tensões antagônicas frente à elite patrimonialista-histórica. Essas crises partem de um modelo constitucional mais avançado que o anterior e concebido de forma a abarcar uma grande parte dos sujeitos que fomentaram aquele momento de hiperpotentia ao longo dos anos 2000, responsáveis pela formação do bloco. Esses avanços merecem destaque, por mais que as pautas não sejam contempladas integralmente e não dependam, tão só, da vontade política do governo, mas, em parte, da correlação de forças envolvidas no contexto político.

Alguns elementos de importância crucial evidenciam-se no processo transformador boliviano:

1) o impulso à participação social;

2) a recuperação dos recursos naturais com as nacionalizações;

3) a política de integração e ocupação nacional, recuperando a soberania em espaços que estavam nas mãos de oligarquias regionais ou locais; 
4) a abertura a uma integração latino-americana anti-imperialista.

Apropriar-se e aumentar a produção de excedente nos setores estratégicos do país, para alcançar a soberania alimentar, energética, etc. sem descuidar ou enfraquecer o bloco histórico formado desde as classes subalternas, é fundamental. A continuidade do bloco tende a permitir 0 aprofundamento do processo revolucionário, tendo o condão de trazer uma maior conscientização das massas através das lutas populares históricas e da atuação do Estado com o propósito de organizar o povo. Assim, mais mecanismos de participação popular podem ser fomentados, ou seja, tratando de empoderar essas massas. Logo, justifica-se, então, dinamizar os processos autonômicos indígenas sem descuidar do papel do Estado em áreas estratégicas e no direcionamento dessas ações. A aceleração dessas iniciativas deve ocorrer juntamente com um processo de reflexão e transformação do papel dos departamentos, como limitadores do desenvolvimento autonômico de regiões e comunidades. Assim poderia ser extrapolada a restrição liberal que constrói a figura da representação do indígena perante o Estado como mero indivíduo, que fala em nome de determinada comunidade de algum departamento, para uma representação legítima enquanto representação de uma coletividade experimentada em seu próprio território e falando por ele. Mesmo o estímulo às autonomias, para além das dinâmicas indígenas próprias, deve ter um aporte do Estado em seu aspecto organizacional como promotor de garantias comunitárias e com 0 propósito de manutenção hegemônica do bloco indígena-popular.

Um rompimento definitivo e integral de algum grupo do bloco histórico que comporta trabalhadores/as, camponeses/as e indígenas tende a desestruturar parte dessa construção do projeto popular. A manutenção dessa unidade é necessária, mesmo com as contradições internas existentes, como única força capaz de enfrentar um cenário de hostilidades e perturbações da elite econômica interna e internacional.

Esse trabalho vem apontar os conflitos e as contradições geradas nos temas considerados fundamentais para o desenvolvimento da sociedade boliviana. Apesar de entender, que em um ambiente democrático, conflitos 
internos são compreensíveis e demonstram a vivacidade do processo. Ademais, não se esquiva de salientar o avanço da reestruturação do Estado Plurinacional a partir de bases transformadoras, as quais apresentam um início de transição, através de um projeto popular em andamento. Não se sabe os rumos que o projeto trilhará, mas alguns pilares assentados na Constituição abrem novas perspectivas para, em um período posterior, vislumbrar um projeto ainda distante, de socialismo comunitário.

A teoria e as experiências históricas demonstram que somente Estados fortalecidos conseguirão dar um salto em direção ao socialismo. Além da Bolívia, esse robustecimento deve permear outros países latino-americanos, que a partir desse processo de reestruturação de suas bases, assumindo 0 protagonismo de suas ações, terão condições de construir um processo de integração real e um caminho rumo a um paradigma socialista. Contudo, ao trilhar esse caminho os conflitos entre os grupos que compõem o bloco histórico indígena-popular não deixarão de existir por completo, uma vez que apresentam pontos que extrapolam a política de fortalecimento do Estado.

Se ousássemos comparar a ruptura boliviana com a Revolução Francesa, mesmo que não se tenha alcançado os objetivos integrais dessa última - igualdade, liberdade e fraternidade -, diríamos que os pilares foram plantados na sociedade. O vivir bien é algo que parte das comunidades, não do Estado que gerou esse discurso. Mas, se um ente estranho ontologicamente ao vivir bien, no caso o Estado, passa a gerar políticas públicas nesse sentido, é um sinal que seus pilares foram redirecionados. O desafio é, de fato, construílo onde é demandado. Essa é uma das questões que a transição constitucional terá que lidar e avançar nas tensões decorrentes dos dias atuais.

A tarefa central de manutenção da unidade não deve se restringir ao ambiente interno boliviano. Até os dias de hoje, a acumulação de capital é uma das questões que marcam o ritmo de desenvolvimento econômico da América Latina. Não é fácil realizar mudanças estruturais só em um país, visto que vivemos em uma economia globalizada. Logo, ressalta-se a importância em integrar países e organizações sociais latino-americanas para construir esse horizonte político popular. A experiência de tentar desnacionalizar o saber e o poder colonial do Estado, reconstruindo-o a partir de uma nova epistemologia 
transformadora adequada e potencializando os processos de integração com perspectivas populares, é um desafio em andamento, permeado por conflitos. No entanto, somente dessa forma, as chances de fissurar os pilares capitalistas serão reais, assim como de sustentar um projeto popular como alternativa necessária à manutenção de hegemonia do bloco histórico subalterno no poder. A ALBA é um tipo de proposta com um grau de solidariedade inédito, tal como a Telesul, o Banco do Sul e a CELAC são alguns exemplos importantes para o avanço desse projeto. A Bolívia compõe todas essas iniciativas.

O cenário político boliviano não indica que, nesse momento, esteja viabilizada uma conjuntura e estrutura de socialização dos meios de produção para a superação do capitalismo. Da mesma forma, não apresenta sinais que a concessão ilimitada de regimes autonômicos aos povos e as nações indígenas aceleraria o horizonte descolonizador ou até mesmo socialista-comunitário. Ainda, cabe ressaltar que até agora, aqueles/as críticos ao programa nacional, democrático e popular direcionado à revolução foram incapazes de formular uma alternativa de programa com tarefas de caráter socialista que se coloque no plano imediato ou até mesmo uma alternativa "pachamamistica" que abarque todos os setores e regiões do Estado e conceba um projeto popular de nação. O sucesso de um projeto unitário, mesmo que plurinacional e popular deve ter um ponto de convergência que, hoje, assenta-se na manutenção do bloco indígena-popular no poder do Estado, amparado pela Constituição de 2009, como possibilidade de aprofundamento do processo transformador na Bolívia. 


\section{REFERÊNCIAS}

- 1020 millones de personas pasan hambre. FAO, Roma, 2009. Disponível em: $<$ https://www.fao.org.br/vernoticias.asp?id_noticia=814>. Acesso em: 19 jun. 2009.

- ALBANESE, 2008. ALBANESE, Susana. La internacionalización del derecho constitucional y la constitucionalización del derecho internacional. In: ALBANESE, Susana (Coord.). El control de Convencionalidad. Buenos Aires: EDIAR, 2008.

- ÁLBO, Xavier. Constituição e Estatutos Autônomos. La Razón, La Paz, 6 abr. 2008.

- ALEXY, Robert. Teoria dos Direitos Fundamentais. Trad. Virgílio Afonso da Silva. 5a edição alemã. São Paulo: Ed. Malheiros, 2008.

- ALMARAZ, Alejandro ¿Repartir la tierra en el umbral de la revolución? In: SVAMPA, Maristela; STEFANONI, Pablo; FORNILLO, Bruno. Balance y perspectivas: intelectuales en el primer gobierno de Evo Morales. La Paz: Le Monde Diplomatique/ Fundación Friederich Ebert, 2010.

- AMIN, Samir. Los desafios de la globalización. México: Siglo XXI, 1997.

- ARANDA, Iván. Entrevistado por Gladstone Leonel da Silva Júnior. La Paz: 12/08/2013.

- ARCE, Carlos. Empleo y relaciones laborales. In: Bolivia hacia el siglo XXI. La Paz: CIDES-UMSA/CNR/CEDLA/CEB/PNUD, 1999.

- ARRIGHI, G. O Longo Século XX. Rio de Janeiro: Contraponto, 1994. 
- ARISTÓTELES. Retórica. Tradução Manuel Alexandre Júnior et. al., 2a edição, Lisboa: Centro de Filosofia da Universidade de Lisboa/Imprensa Nacional-Casa da Moeda, 2005.

- ARKONADA, Katu. (Coord.) Transiciones hacia el vivir bien. O la construcción de un nuevo proyecto político en el Estado Plurinacional de Bolivia. La Paz: Ministerio de Culturas, 2012.

- AYALA UGARTE, A.; DERPIC Jorge. Bolivia: los linchados de El Alto. Anfibia. Universidad Nacional de San Martin: Buenos Aires. 04 nov. 2013. Disponível em: http://www.revistaanfibia.com/cronica/bolivia-los-linchados-deel-alto/pagina-1. Acesso em: 15 mai. 2014.

- BAJO, Ricardo; ARKONADA, Katu. Esta revolución política y descolonizadora debe dar lugar a una revolución económica post capitalista. Entrevista a Álvaro García Linera. Le Monde Diplomatique. La Paz, diciembre 2012.

- BAMBIRRA, Vânia. O Capitalismo Dependente Latino-Americano. Florianópolis:Insular, 2012.

- BARBIER, René. Pesquisa-ação na instituição educativa. Rio: Zahar, 1985.

- BARROSO, Luis Roberto. A doutrina brasileira da efetividade. In: Temas de Direito Constitucional. V.3, Rio de Janeiro: Renovar, 2005.

Da falta de efetividade à judicialização excessiva: direito à saúde, fornecimento gratuito de medicamentos e parâmetros para a atuação judicial. In: Interesse Público. Belo Horizonte: Fórum. v. 9, n. 46, p. 31-61, nov./dez. 2007.

- BECERRA, Félix. Entrevistado por Gladstone Leonel da Silva Júnior. La Paz: 14/08/2013. 
- BENJAMIN, César. Um projeto popular para o Brasil. In: BENJAMIN, César; CALDART, Roseli Salete (orgs). Projeto Popular e escolas do campo. Por uma educação básica no campo. Brasília - DF: ANCA, Coleção Por uma educação Básica do Campo, n 3, 2000, p. 15-37.

- BOBBIO, Norberto. Liberalismo e democracia. 6 ed. São Paulo: Brasiliense, 1997.

- BOFF, Leonardo. Saber cuidar: Ética do Humano. In: Consulta Popular (Org.). Valores de uma Prática Militante. Cartilha ํo9, 3 ed. São Paulo; [s.n] 2001.

- BOLIVIA. Plan Nacional de Desarrollo: Bolivia digna, soberana, productiva y democrática para vivir bien. Lineamentos estratégicos. 2006-2011. La Paz: Gaceta oficial de Bolivia, 2007.

Órgano Electoral Plurinacional - OEP. La Paz, 2009. Disponível em: http://www.oep.org.bo/. Acesso em: 24 abr. 2014.

Informe del gobierno del Estado Plurinacional de Bolivia sobre los derechos de los pueblos indígenas. Nueva York: ONU, 2012.

. Ministério de Hidrocarburos. Decreto Supremo 28.701. Disponível em: www.hidrocarburos.gov.bo/Ministerio/Decretos/DS_28701.pdf. Acesso em 10 dez. 2013.

Censo Nacional de Población y Vivienda 2012. (CNPV 2012). Instituto Nacional de Estadística - INE: La Paz, 2013 BOLIVIA. Censo Nacional de Población y Vivienda 2012. (CNPV 2012). Instituto Nacional de Estadística - INE: La Paz, 2013a.

Memoria Institucional 2012. Gerencia Nacional de Recursos Evaporíticos COMIBOL. La Paz: All Press Labores Graficas, 2013b. 
$-$ Presidente Morales promulga ley de Ampliación del Saneamiento de Tierras. INRA. Instituto Nacional de Reforma Agraria. La Paz, out. 2013c. Disponível em: http://www.inra.gob.bo/lnraPb/paginaController;jsessionid=E58372E735F3EDF 439EBA5D1A29659CF?cmd=noticia\&id=8230. Acesso em: 19 mar. 2014.

- BONAVIDES, Paulo. Do Estado Liberal ao Estado Social. 6ª ed. São Paulo: Malheiros Editores, 1996.

- BOSTEELS, Bruno. El marxismo em América Latina. Nuevos caminos al comunismo. La Paz: Vicepresidencia del Estado Plurinacional, 2013.

- BRANDÃO, Pedro A.D.M. O Novo Constitucionalismo Pluralista LatinoAmericano: participação popular e cosmovisões indígenas (Pachamama e Sumak Kawsay). Dissertação de mestrado. Programa de Pós-graduação em Direito da Faculdade de Direito do Recife, Recife, 2013.

- BUHL. Cindy. A Citizen's Guide to the Multilateral Development Banks and Indigenous Peoples. Washington, D.C.: The Bank Information Center, 1994.

- CARBONELL, Miguel. El Constitucionalismo en su Laberinto. In: Miguel Carbonell (Org.), Teoría del Neoconstitucionalismo. Editorial Trotta, Coleccion Estructuras Y Processos, Serie Derecho. Madrid, 2007.

- CARVALHO, José Murilo de. Cidadania no Brasil. O Longo Caminho. 3. ed. Rio de Janeiro: Civilização Brasileira, 2002.

- CASTRO, Fidel. La historia me absolverá. Quinta reimpresión. La Havana: Editorial de Ciencias Sociales, 2007.

- CENTRO DE ESTUDIOS CONSTITUCIONALES. Constitución Política del Estado: anotada, concordada y comentada. La Paz, 2013. Disponível em: http://econstitucional.com/. Acesso em: 22 fev. 2014. 
- CHAVÉZ, Marxa N; NEHE, Borries E. Dominación y rebelión en oriente boliviano. La construcción de Oriente y el Cerco a Santa Cruz. In: CHAVÉZ, Marxa N., et al. Ahora es cuando? Bolivia: cambios y contradicciones. Ciudad de México: Colectivo Katar Uta, 2011.

- CHE. Agencia France Presse, AFP, Paris, 2006.

- CHIVI VARGAS, Idón. Los desafíos de la justicia comunitaria y bases para una "ley de deslinde jurisdiccional". La Paz: IDEA Internacional, 2009a.

- Los caminos de la descolonización por América Latina: Jurisdicción Indígena Originaria Campesina y el Igualitarismo Plurinacional Comunitario. In: ESPINOSA GALLEGO-ANDA, Carlos; CAICEDO TAPIA, Danilo (Edit.). Derechos ancestrales. Justicia en contextos plurinacionales. Quito: Ministerio de Justicia y derechos humanos, 2009b.

- Nueva constitución y desarrollo normativo. Agencia Latinoamericana de Información América en Movimiento. Quito, 2010. Disponível em: http://alainet.org/active/35872\&lang=es>. Acesso em: 12 jun. 2012.

Descolonización y despatriarcalización en las políticas públicas. In: ARKONADA, Katu (Coord.) Transiciones hacia el vivir bien. O la construcción de un nuevo proyecto político en el Estado Plurinacional de Bolivia. La Paz: Ministerio de Culturas, 2012, p. 17-50.

$15 / 08 / 2013$.

Entrevistado por Gladstone Leonel da Silva Júnior. La Paz:

- CHIZZOTTI, Antonio. Pesquisa qualitativa em ciências humanas e sociais. Petrópolis:Vozes, 2006.

- CLAVERO, Bartolomé. Bolivia entre constitucionalismo colonial y constitucionalismo emancipatório. In: CHIVI VARGAS (Org.). Bolivia. Nueva Constitución Política del Estado. Conceptos elementales para su desarrollo normativo. La Paz: Vicepresidencia del Estado Plurinacional de Bolivia, 2010. 
- COELHO, Fábio Ulhôa. Manual de Direito Comercial: direito de empresa. $25^{a}$ ed. São Paulo: Saraiva, 2013.

- CONAMAQ. Plan Estrategico 2008-2013. La Paz/ Chuquiagumarka, 2008.

- CONDORI, Damián. Entrevistado por Gladstone Leonel da Silva Júnior. La Paz: 14/08/2013.

- CONSTANT, Benjamin. Da liberdade dos antigos comparada à dos modernos. In: Filosofia Política. $n^{\circ}$ 2. Trad. Loura Silveira. Porto Alegre: L\&PM, 1985.

- COSTA, Alexandre Bernardino. Desafios da Teoria do Poder Constituinte no Estado Democrático de Direito. 2005. Tese (Doutorado em Direito). Faculdade de Direito da Universidade Federal de Minas Gerais. Belo Horizonte, 2010.

- DIEHL, Diego A.; LEONEL JÚNIOR, Gladstone. A descolonialidade do saber jurídico na dialética social do direito de Roberto Lyra Filho.In: II Seminário Direito, pesquisa e movimentos sociais. 26-28 abr. 2012, Cidade de Goiás. Anais. Cidade de Goiás: Instituto de Pesquisa, Direitos e Movimentos Sociais, 2013.

- DO ALTO, Hervé. Un partido campesino en el poder. Una mirada sociológica del MAS boliviano. In: Nueva Sociedade. n²34, Ago. 2011.

- DUSSEL, Enrique. Filosofia da Libertação na América Latina. Trad. Luiz João Gaio. São Paulo: Loyola, 1986. Liberación de la mujer y erótica latinoamericana. $4^{\mathrm{a}} e d$. , Bogotá: Editorial Nueva América, 1990.

. La produción teórica de Marx. Um comentário a los Grundrisse. $2^{2}$ ed. México-DF: Siglo XXI Editores, 1991. 
1492: o encobrimento do outro: a origem do mito da modernidade: Conferências de Frankfurt. Trad. Jaime A. Classen. Petrópolis, RJ: Vozes, 1993.

2001.

Hacia una filosofía política crítica. Bilbao: Desclée de Brouwer,

20 Teses de política. Trad. Rodrigo Rodrigues. Buenos Aires: Consejo Latinoamericano de Ciencias Sociales - CLACSO; São Paulo: Expressão Popular, 2007.

Política de la liberación: arquitectónica. Madrid: Trotta, vol. II,

2009.

2011.

Filosofía de la Liberación. México: Fondo de Cultura Económica,

- DWORKIN, Ronald. $O$ império do direito. Trad. Jefferson Luiz Camargo. São

Paulo: Martins Fontes, 2003.

- ENGELS, Friedrich. A origem da família, da propriedade privada e do Estado. São Paulo: Centauro, 2002.

- FAJARDO. Raquel Z. Yrigoyen. El horizonte del constitucionalismo pluralista: del multiculturalismo a la descolonización. In: El derecho en América Latina: un mapa para el pensamiento jurídico del siglo XXI. (Coord.) César Rodríguez Garavito. Buenos Aires: Siglo Veintiuno Editores, 2011.

- FALS BORDA, O. Os aspectos teóricos da pesquisa participante: considerações sobre o significado e o papel da ciência na participação popular. In: BRANDÃO, C.R. (Org.) Pesquisa Participante. 3 ed., São Paulo: Brasiliense, 1983.

- FAO 1020 millones de personas pasan hambre. Roma, 2009. Disponível em: <https://www.fao.org.br/vernoticias.asp?id_noticia=814>. Acesso em: 19 jun. 2009. 
- FLORES, Joaquin Herrera. Teoria crítica dos direitos humanos. Os direitos humanos como produtos culturais. Rio de Janeiro: Lumen luris, 2009.

- FUNDACIÓN TIERRA. Alejandro Almaraz sale del Viceministerio de tierras. La Razón. La Paz. 02 fev. 2010. Disponível em: http://www.ftierra.org/index.php?option=com_content\&view=article\&id=2032:rair \&catid=98:noticias\&ltemid=175. Acesso em: 19 mar. 2014.

Totora: Tribunal Constitucional declara constitucional el primer estatuto indígena. Notícias. La Paz. 06 fev. 2014. Disponível em: http://www.ftierra.org/index.php?option=com_content\&view=article\&id=18106:2 014-02-06-21-57-43\&catid=177: autonomias-indigenas\&ltemid=243. Acesso em: 20 mar. 2014.

- GALEANO, Eduardo. 0 livro dos Abraços. Trad. Eric Nepomuceno. 9a ed. Porto Alegre: L\&PM, 2002. Siglo veintiuno Editores, 2010.

Las venas abiertas de América Latina. $13^{\mathrm{a}}$ ed. Buenos Aires:

$\overline{2012 .}$ Os filhos dos dias. Trad. Eric Nepomuceno. Porto Alegre: L\&PM, De pernas pro ar: a escola do mundo ao avesso. Trad. Eric Nepomuceno. Porto Alegre: L\&PM, 2013.

- GARCIA LINERA, Álvaro. La crisis del estado y las sublevaciones indígenoplebeyas. In: TAPIA, Luis; GARCÍA, Álvaro; PRADA, Raúl. Memorias de octubre. La Paz: Muela del Diablo, 2004, pp.27-86.

El "capitalismo andino amazônico". Le monde diplomatique. ed. chilena. Santiago, jan. 2006, Disponível em: http://www.lemondediplomatique.cl/El-capitalismo-andino-amazonico.html. Acesso em: 28 jan. 2014. 
. La muerte de la condición obrera del siglo XX: la marcha minera por la vida. In: GARCÍA, Álvaro; GUTIERREZ, Raquel; PRADA, Raúl; TAPIA, Luis. El retorno de la Bolivia plebeya. La Paz: Muela del Diablo, 2ed., 2007, pp.23-60.

Estado Plurinacional: una propuesta democrática y pluralista para la extinción de la exclusión de las naciones indígenas. In: LINERA, Álvaro Garcia; TAPIA M., Luís; ALCOREZA, Raul Prada. (Org.) La transformación pluralista del Estado. La Paz: Muela del diablo, 2007b.

La potencia plebeya. Acción colectiva e identidades indígenas, obreras y populares en Bolivia. La Paz: Prometeo libros/Clacso, 2008.

Forma valor y forma comunidad. Aproximación teórica-abstracta a los fundamentos civilizatorios que preceden al Ayllu Universal. La Paz: Clacso/ Muela del Diablo, 2009.

. Punto de bifurcación y consolidación del nuevo Estado. In: SVAMPA, Maristela; STEFANONI, Pablo; FORNILLO, Bruno. Balance y perspectivas: intelectuales en el primer gobierno de Evo Morales. La Paz: Le Monde Diplomatique/ Fundación Friederich Ebert, 2010a.

. El Estado en transición. Bloque de poder y punto de bifurcación. In: GARCIA LINERA, Álvaro; TAPIA M., Luís; ALCOREZA, Raul Prada, CAMACHO, Oscar Vega. (Org.) El Estado. Campo de lucha. La Paz: Muela del diablo, 2010b.

Las tensiones creativas de la Revolución: la quinta fase del proceso de cambio. 4ㄹed., La Paz: Vicepresidencia del Estado Plurinacional, $2012 \mathrm{a}$.

Geopolítica de la Amazonía. Poder hacendal-patrimonia y acumulación capitalista. La Paz: Vicepresidencia del Estado Plurinacional, 2012b. 
- GARCÍA MARQUEZ, Gabriel. Cem anos de solidão. Trad. Eliane Zagury. Col. Mestres da Literatura Contemporânea, Rio de Janeiro: Record, 1967.

- GARGARELLA. Roberto. COURTIS, Christian. EI nuevo constitucionalismo latinoamericano: Promesas e interrogantes. CEPAL - Serie Políticas Sociales. Santiago: Naciones Unidas, 2009.

- GARGARELLA. Roberto. Pensando sobre la Reforma constitucional en América Latina. In: El derecho en América Latina: un mapa para el pensamiento jurídico del siglo XXI. (Coord.) César Rodríguez Garavito. Buenos Aires: Siglo Veintiuno Editores, 2011.

- GARRET, David T. Sombras del Imperio: la nobleza indígena de Cuzco, 1750-1825. Lima: IEP, 2009.

- GIMENEZ, H. M. O desenvolvimento da cadeia produtiva da soja na Bolívia e a presença brasileira: uma história comum. 2010. 323f. Dissertação (Mestrado). Programa de Pós-Graduação em integração da América Latina, Universidade de São Paulo, São Paulo, 2010.

- GOMES. Orlando. A crise do direito. São Paulo: Max Limonad, 1955.

- GOMES E SOUZA, Júlia. Crise do neoliberalismo e seus reflexos no aparelho estatal: apontamentos para a reflexão do caso boliviano. Campinas, $2009 . \quad$ Disponível em: http://www.ifch.unicamp.br/formulario_cemarx/selecao/2009/trabalhos/crise-doneoliberalismo-e-seus-reflexos-no-aparelho-estatal.pdf. Acesso: 28 jan. 2014.

- GÓMEZ VELA. Bolívia. La mentira de año. Consulta em el TIPNIS. Erbol. La Paz, 11 jan. $2013 . \quad$ Disponível em: www.erbol.com.bo/opinion/tinku_verbal/la_mentira_del_ano. Acesso em 31 mar. 2014. 
- GONSALVEZ, Gonzalo. La economía comunitaria y el vivir bien en El Estado Plurinacional de Bolivia. In: ARKONADA, Katu (Coord.) Transiciones hacia el vivir bien. O la construcción de un nuevo proyecto político en el Estado Plurinacional de Bolivia. La Paz: Ministerio de Culturas, 2012, p. 151-180.

- GRAMSCI, Antonio. Cuadernos de la cárcel. Trad. Ana Maria Pálos. Tomo 1. México-DF : Ediciones Era, 1981a.

Cuadernos de la cárcel. Trad. Ana Maria Pálos. Tomo 2. MéxicoDF : Ediciones Era, 1981b.

Cuadernos de la cárcel. Trad. Ana Maria Pálos. Tomo 3. México-DF : Ediciones Era, 1984.

Cuadernos de la cárcel. Edición crítica del instituto Gramsci a cargo de Valentino Gerratana.Trad. Ana Maria Pálos. Tomo 5. México-DF : Ediciones Era, 1999.

Cuadernos de la cárcel. Edición crítica del instituto Gramsci a cargo de Valentino Gerratana.Trad. Ana Maria Pálos. Tomo 6. México-DF: Ediciones Era, 1, 2000.

Cadernos do cárcere. (Org.) Carlos Nelson Coutinho, Marco Aurélio Nogueira e Luiz Sérgio Henriques. Vol. 3. Rio de Janeiro: Civilização Brasileira, 2007.

- GUNDER FRANK, Andre. Acumulação dependente e subdesenvolvimento. São Paulo: Brasiliense, 1980. 
- GUTIERREZ, Raquel; GARCÍA, Álvaro; TAPIA, Luis. La forma multitud de la política de las necesidades vitales. In: GARCÍA, Álvaro; GUTIERREZ, Raquel; PRADA, Raúl; TAPIA, Luis. El retorno de la Bolivia plebeya. La Paz: Muela del Diablo, 2ed., 2007 , pp.143-194.

- GUZMÁN, Ismael. Bolivia: el voto comunitário. CipcaNotas. Boletín Virtual, n'322, ano 8, La Paz, 2009. Disponível em: http://alainet.org/active/35214\&lang=es. Acesso em: 04 abr. 2014.

- HAGUETTE, Teresa M. F. Metodologias qualitativas na sociologia. 8 ed. Petrópolis: Vozes, 2001.

- HEGEL, G. W. F. Filosofia da História. Trad. Maria Rodrigues e Hans Harden. Brasília: UnB, 1999.

- HEMEROTECA. Biblioteca del Archivo Histórico de la Asamblea Legislativa Plurinacional. La Razón. La Paz, 6 de abril 2000.

Biblioteca del Archivo Histórico de la Asamblea Legislativa Plurinacional. La Razón. La Paz, 11 de outubro 2006.

- Biblioteca del Archivo Histórico de la Asamblea Legislativa Plurinacional. La Razón. La Paz, 8 de agosto 2007.

- Biblioteca del Archivo Histórico de la Asamblea Legislativa Plurinacional. La Razón. La Paz, 22 de dezembro 2007b.

Plurinacional. La Razón. La Paz, 08 de março 2007 c. 
$-$ Biblioteca del Archivo Histórico de la Asamblea Legislativa Plurinacional. La Razón. La Paz, 12 de outubro 2007d.

. Biblioteca del Archivo Histórico de la Asamblea Legislativa Plurinacional. La Prensa. La Paz, 08 de fevereiro 2009.

- HILFERDING, Rudolf. O Capital Financeiro. São Paulo, Abril Cultural, 1985.

- HOLMES, Stephen. El precompromiso y la paradoja de la democracia. In: ELSTER, Jon; SLAGSTAD, Rune. Constitucionalismo y democracia. Trad. Mônica Utrilla de Neira. Mexico, D.F.: Fondo de Cultura Econômica, 1999.

- HUANACUNI, Fernando. Vivir Bien/Buen Vivir. Filosofía, políticas, estrategias y experiencias regionales. In: ARKONADA, Katu (Coord.) Transiciones hacia el vivir bien. O la construcción de un nuevo proyecto político en el Estado Plurinacional de Bolivia. La Paz: Ministerio de Culturas, 2012, p. 127-150.

- HUARIN, Lucila Choque. Las mujeres en Bolivia y sus movilizaciones por el vivir bien. In: ARKONADA, Katu (Coord.) Transiciones hacia el vivir bien. $O$ la construcción de un nuevo proyecto político en el Estado Plurinacional de Bolivia. La Paz: Ministerio de Culturas, 2012, p. 79-103.

- IAMAMOTO. S.A.S. 0 nacionalismo boliviano em tempos de plurinacionalidade: Revoltas antineoliberais e constituinte (2000-2009). Dissertação de mestrado. Departamento de Ciência Política da Universidade de São Paulo, São Paulo, 2011.

- ICHUTA NINA. Carlos Ernesto. Capitalismo Andino. La Razón. La Paz. Out. 2012. Disponível em: http://www.la-razon.com/opinion/columnistas/Capitalismoandino_0_1702029806.html. Acesso em 13 mar. 2014. 
- INE, Instituto Nacional de Estadísticas. Bolivia: exportaciones. 2012. Disponível em: http://www.ine.gob.bo/indice/general.aspx?codigo=50101. Acesso em: 24 abr. 2014.

- INICIAN ensamblaje de baterías para celulares en Uyuni. Pagina siete. La Paz. 18 fev. 2014.2 Disponível em: http://www.paginasiete.bo/economia/2014/2/18/inician-ensamblaje-bateriaspara-celulares-uyuni-14267.html. Acesso em: 20 mar. 2014.

- KUHN. Thomas. A estrutura das revoluções científicas. Trad. Beatriz Viera; Nelson Boeira. 5 $\square$ ed., São Paulo: Perspectiva, 1998.

- KRUSE, Thomas. La "Guerra del Agua" em Cochabamba, Bolivia: terrenos complejos, convergências nuevas. In: TOLEDO. Enrique de la Garza. (Org.) Sindicatos y nuevos movimentos sociales em América Latina. Colección Grupos de Trabajo de CLACSO, Buenos Aires, Argentina, 2005.

- LACERDA, Rosane F. "Volveré y será millones": Contribuições descoloniais dos movimentos indígenas latino-americanos para a superação do mito Estado-Nação. Tese de doutorado. Programa de Pós-graduação em Direito da Faculdade de Direito da Universidade de Brasília, Brasília, 2014.

- LANDER, Edgardo (org.). A colonialidade do saber: eurocentrismo e ciências sociais - perspectivas latino-americanas. Tradução de Júlio César Casarin Barroso Silva. Buenos Aires: CLACSO, 2005.

- LASERNA ROJAS, Roberto; PACHECO, Carlos Miranda; TORRICO, Mário Napoleón Pacheco. Control estatal de recursos naturales y rentismo. In: LASERNA, Roberto et. all. Poder y cambio en Bolivia: 2003-2007. La Paz: Embajada del Reino de los Países Bajos, Fundación PIEB, 2009.

- LENIN. Wladimir llytch. Imperialismo, fase superior do capitalismo. 1917. Editorial Avante, Edições Progresso: Lisboa, 1984. Disponível em: http://marxists.anu.edu.au/portugues/lenin/1916/imperialismo/index.htm.

Acesso em 16 jan. 2014. 
. O Estado e Revolução: o que ensina o marxismo sobre o Estado e o papel do proletariado na Revolução. Trad. Aristides Lobo. São Paulo: Expressão Popular, 2007.

. Que Fazer?. São Paulo: Expressão Popular, 2010.

- LEONEL JÚNIOR, Gladstone. Do sujeito revolucionário europeu ao ator coletivo da hiperpotentia latino-americana: para a construção de uma nova hegemonia político-jurídica na América Latina. In: XXIX Congresso ALAS, 2013, Santiago. Anais. Crisis y emergencias sociales en America Latina. Santiago, 2013a.

A insuficiência das instituições e da atual concepção de Estado de Direito para uma análise jurídico-transformadora da América Latina. In: Revista O Direito Alternativo. Expressões do Direito Alternativo na América Latina. Vol. 2, Franca: UNESP, 2013b, p. 6-24.

O pluralismo jurídico transformador latino-americano frente à incapacidade institucional e do moderno Estado de Direito. In: WOLKMER, Antonio Carlos; CORREAS, Oscar. (Org.). Crítica Jurídica na América Latina. Aguascalientes: CENEJUS, 2013c, v. 1, p. 304-317.

- Soberania Popular e Constituinte Exclusiva: uma visão desde nuestra América. In: RIBAS, Luiz Otávio (Org.). Constituinte Exclusiva: um novo sistema político é possível. São Paulo: Expressão Popular, 2014a, p.95103.

O fenômeno do novo constitucionalismo latino-americano: o advento do processo transformador. In: GUERRA, Roberta F.; DA SILVA, Fernando L. A.; DEL NERO, Patrícia. Neoconstitucionalismo em perspectiva. Viçosa: Editora UFV, 2014b, p. 368-380.

- LINS RIBEIRO, Gustavo. Post-imperialismo: para una discusión después del post-colonialismo y del multiculturalismo. In: Daniel Mato. Cultura, política y sociedad Perspectivas latinoamericanas. CLACSO, Consejo Latinoamericano de Ciencias Sociales, Ciudad Autónoma de Buenos Aires, Argentina. 2005. pp. 41-67. 
- LORENZO G. Ángel Haraol. Elecciones judiciales en el Estado Plurinacional de Bolivia III: el resultado final. Revista Andina de Estudios Políticos. n¹0. Lima: Observatório Andino. Octubre-Noviembre 2011.

- LYRA FILHO, Roberto. Para um Direito Sem Dogmas. Porto Alegre: S. A. Fabris, 1980.

Fabris, 1982.

Direito do Capital e Direito do Trabalho. Porto Alegre: S. A. Karl, Meu Amigo: Diálogo com Marx sobre o Direito. Porto Alegre: S. A. Fabris, 1983.

. Desordem e Processo. Porto Alegre: S. A. Fabris, 1986.

Brasiliense, 2006.

O que é Direito. $15^{\mathrm{a}}$ reimpr. da 17ª ed. 1995. São Paulo: Ed.

- MACCORMICK, Neil. Retórica e o Estado de Direito. Uma teoria da argumentação jurídica. Trad. Conrado Hubner Mendes e Marcos Paulo Veríssimo. Rio de Janeiro: Elsevier, 2008.

- MACHADO. Antônio Alberto. A teoria do direito e os paradigmas positivistas. In: BORGES. Paulo César Corrêa. Marcadores Sociais da diferença e repressão penal. São Paulo: NETPDH; Cultura Acadêmica Editora, 2011.

-MADISON, James; HAMILTON, Alexander; JAY, John. Os Artigos Federalistas. Apresentação: Isaac Kramnick; tradução de Maria Luiza X. de A. Borges. Rio de Janeiro: Nova Fronteira, 1993. 
- MAGALHÃES, José Luiz Quadros de. O Estado Plurinacional Na América Latina. Conteúdo Jurídico. Brasília-DF: 27 mar. 2009. Disponível em: $<\mathrm{http}: / / \mathrm{www}$.conteudojuridico.com.br/?colunas\&colunista=50\&ver=257>. Acesso em: 01 out. 2014.

2012.

Estado Plurinacional e direito internacional. Curitiba: Juruá,

- MAGDALENA, Armando. El Marxismo embrujado. In: MARIATEGUI. José Carlos. José Carlos Mariátegui: escritos fundamentales. Avellaneda: Acércandonos Editorial, 2008.

- MARIATEGUI. José Carlos. El problema de las razas en la América Latina. In: MARIATEGUI, MARIATEGUI. José Carlos. José Carlos Mariátegui: escritos fundamentales. Avellaneda: Acércandonos Editorial, 2008, p. 55-74.

Sete ensaios de interpretação da realidade peruana. Trad. Felipe José Lindoso. São Paulo: Expressão Popular: Clacso, 2008b.

- MARINI, Ruy Mauro. Dialética da dependência. In: TRASPADINI, Roberta; STÉDILE, João Pedro (orgs.). Ruy Mauro Marini. Vida e obra. São Paulo: Expressão Popular, 2005.

- MARTÍNEZ, Paola; LINSALATA, Lucía. Las asimetrías del mandar obedeciendo en Bolivia. In: CHAVÉZ, Marxa N., et al. Ahora es cuando? Bolivia: cambios y contradicciones. Ciudad de México: Colectivo Katar Uta, 2011.

- MARTÍNEZ DALMAU, Rubén. El nuevo constitucionalismo latinoamericano y el proyecto de Constitución del Ecuador de 2008.In: Alter Justitia: Estudios sobre teoría y justicia constitucional. Guayaquil-Ecuador, ano 2, n. 1, oct. 2008a. 
Asambleas constituyentes y nuevo constitucionalismo en América Latina. Tempo Exterior. Illa de San Simón - España, n॰17, Julio-diciembre, 2008b, p. 5-15.

- MARTÍNEZ DALMAU, Rubén; LEONEL JÚNIOR, Gladstone. O novo constitucionalismo latino-americano $e$ as possibilidades da constituinte no Brasil. In: RIBAS, Luiz Otávio (Org.). Constituinte Exclusiva: um novo sistema político é possível. São Paulo: Expressão Popular, 2014, p.27-35.

- MARTÍNEZ DALMAU, Rubén; VICIANO PASTOR, Roberto. ¿Se puede hablar de un nuevo constitucionalismo latinoamericano como corriente doctrinal sistematizada? In: Nuevas tendencias del derecho constitucional en América Latina, VIII Congreso Mundial de la Asociación Internacional de Derecho Constitucional: constituciones y principios, México, dez. 2010a. Disponível em: <www.juridicas.unam.mx/wccl/ponencias/13/245.pdf>. México. Acesso em: 30 abr. 2012.

- _. Aspectos generales del nuevo constitucionalismo latinoamericano. In: El nuevo constitucionalismo en América Latina: memorias del encuentro internacional el nuevo constitucionalismo: desafíos y retos para el siglo XXI. Corte Constitucional del Ecuador, Quito, 2010b.

Mujeres y constitucionalismo transformador en América Latina. In: Igualdad y democracia: el género como categoría de análisis jurídico. Valencia: Corts Valencianes, 2014, p.431-442.

- MARTINS, Antônio. Economia: o notável exemplo da Bolívia. Carta Capital. São Paulo, fev. 2014. Disponível em: http://www.cartacapital.com.br/blogs/outras-palavras/economia-o-notavelexemplo-da-bolivia-6693.html. Acesso em: 15 mar. 2014.

- MARTINS, Carlos Eduardo. O pensamento de Ruy Mauro Marini e sua atualidade para as ciências sociais. In: ALMEIDA FILHO, Niemeyer (Org.). Desenvolvimento e dependência: cátedra Ruy Mauro Marini. Brasília: Ipea, 2013. 
- MARX, Karl. Para a crítica da economia política. In: MARX, Karl. Trad. Edgar Malagodi. 2. ed. São Paulo: Ed. Abril Cultural, 1978a. p. 101-132. (Os Pensadores). Humanas. Ltda, 1978b.

Livro I, Capítulo VI (inédito) In: O Capital. São Paulo: Ciências

Primeiro projeto de resposta à Carta de Vera Zassúlitch. 1881. Trad. José Barata-Moura. Editorial Avante, Edições Progresso: Lisboa, 1982. Disponível em: http://marxists.org/portugues/marx/1881/03/vera.htm. Acesso em: 15 jan. 2014.

. O Capital: crítica da economia política. Vol. I, tomo I. Trad. Regis Barbosa e Flávio Kothe. São Paulo: Abril Cultural, 1983.

O Capital. crítica da economia política. Vol. I, Tomo I, Trad. Regis Barbosa; Flávio Kothe. São Paulo: Editora Nova Cultural, 1996.

A questão irlandesa. Trad. Alexandre Linares. 1869. Disponível em: http://marxists.org/portugues/marx/1869/11/questao.htm. 2004. Acesso em 15 jan. 2014.

Grundrisse: manuscritos econômicos de 1857-1858: esboços da crítica da economia política. Trad. Mário Duayer e Nélio Schneider. São Paulo: Boitempo; Rio de Janeiro: Ed. UFRJ, 2011a.

O 18 Brumário de Luís Bonaparte. Trad. Nélio Schneider. São Paulo: Boitempo editorial, 2011b.

A Guerra Civil na França. Trad. Ruben Enderle. São Paulo: Boitempo editorial, 2011c.

As lutas de classe na França de 1848 a 1852. Trad. Nélio Schneider. São Paulo: Boitempo editorial, 2012a. 

Crítica do programa de Gotha. Tradução de Rubens Enderle. São Paulo: Boitempo, 2012b.

- MARX, Karl; ENGELS, Friedrich. Manifesto do Partido Comunista. 6 $6^{\mathbf{a}}$ ed. São Paulo: Global Editora, 1986.

- MIGNOLO, Walter D. Histórias locais/Projetos globais: colonialidade, saberes subalternos e pensamento liminar. Tradução de Solange Ribeiro de Oliveira. Belo Horizonte: UFMG, 2003.

- MOLDIZ MERCADO, Hugo. El vivir bien, ¿un proyecto alternativo al capitalismo? In: ARKONADA, Katu (Coord.) Transiciones hacia el vivir bien. O la construcción de un nuevo proyecto político en el Estado Plurinacional de Bolivia. La Paz: Ministerio de Culturas, 2012, p. 197-219.

- MOLINA BARRIOS, R. Los Pueblos Indígenas de Bolivia: diagnóstico sociodemográficos partir del censo del 2001. Santiago: CEPAL, 2005.

- MONTERO, Lourdes. Una economía para la inclusión. In: VVAA. Miradas. Nuevo Texto Constitucional. La Paz: UMSA; Vicepresidencia del Estado Plurinacional; IDEA Internacional, 2010.

- MORAES, Ana Paula Bagaiolo; LEONEL JÚNIOR, Gladstone. A cidadania e a evolução dos direitos fundamentais no Brasil. In: Revista de Estudos Jurídicos UNESP. n॰21, Franca, 2011.

- MORALES, Evo. Palabras del Presidente del Estado Plurinacional de Bolivia, Evo Morales Ayma, en la promulgación de la nueva Constitución Política del Estado. Enciclopedia Histórica Documental de Proceso Constituyente Boliviano. La Paz: Vicepresidencia del Estado; Presidencia de la Asamblea Legislativa Plurinacional, 2009.

- MOTA, Aurea. A nova Constituição política do Estado boliviano. Antecedentes históricos, conteúdo e proposta analítica. In: DOMINGUES. José Maurício...[et. all.]. (Org.). A Bolívia no espelho do futuro. Belo Horizonte: UFMG; Rio de Janeiro: IUPERJ, 2009. 
- NEGRI, Antonio; HARDT, Michael. Multidão. 2ª̣ed. São Paulo: Record, 2005.

- NEGRI, Toni; HARDT, Michel; COCCO, Giuseppe; REVEL, Judith; LINERA, Álvaro Garcia; TAPIA, Luis. Imperio, multitud y sociedad abigarrada. La Paz: CLACSO, Muela del Diablo, Comunas, Vicepresidencia del Congreso Nacional Boliviano, 2008.

- NETTO, José Paulo. (curso) O Método em Marx. Faculdade de Serviço Social da Universidade Federal de Pernambuco, 2002. Disponível em <http://www.cristinapaniago.com/jos\%C3\%A9_p_netto_curso_o_m\%C3\%A9todo_em_marx_-_. Acesso em 25 nov. 2009.

- NOGUERA FERNANDÉZ, Albert. ¿De qué hablamos cuando hablamos de constitucionalismo multicultural? Anuario de la Faculdad de Derecho, vol. XXVIII, 2010, p.87-116.

- ONU reconheceu a nova denominação oficial do estado boliviano em 7 de abril de 2009. Wikipedia. Disponível em: <http://pt.wikipedia.org/wiki/Bolivia\#cite_note-novonome-0.> Acesso em: 15 de Maio de 2010.

- PACTO DE UNIDAD. Propuesta consensuada del Pacto de Unidad. Constitución Política del Estado. Por un Estado Plurinacional Comunitario, Libre, Independiente, Soberano, Democrático y Social. Sucre, 2007. Disponível em: www.redunitas.org/pacto_unidad.pdf. Acesso em: 18 fev. 2014.

- PANNAIN, Rafaela Nunes. A crise do Estado boliviano e a autonomia indígena. Tese de doutorado. Departamento de Sociologia da Faculdade de Filosofia, Letras e Ciências Humanas da Universidade de São Paulo, São Paulo, 2014.

sociedade. In:

Crises Políticas. O descompasso entre o poder político e a , livro, editora, ano, p. NO PRELO.

- PASUKANIS, E. B. A teoria geral do direito e o marxismo. Trad. Paulo Bessa. Rio de Janeiro: Renovar, 1989. 
- PAZ RADA, Eduardo. Entrevistado por Gladstone Leonel da Silva Júnior. La Paz: 22/07/2013.

- PORTELLI, Hugues. Gramsci e o bloco histórico. Trad. Angelina Peralva. Rio de Janeiro: Paz e Terra, 1977.

- PRADA, Raul. Política de las multitudes. In: TAPIA, Luis; GARCÍA, Álvaro; PRADA, Raúl. Memorias de octubre. La Paz: Muela del Diablo, 2004, pp.87136.

- Estado periférico y sociedad interior. In: PRADA, Raúl; CAMACHO, Oscar Vega; TAPIA, Luis; GARCÍA, Álvaro. Horizontes y límites del estado y el poder. La Paz: Muela del Diablo, 2005, pp.133-215.

- Horizontes del Estado Plurinacional. In: VVAA. Miradas. Nuevo texto Constitucional. La Paz: UMSA; Vicepresidencia del Estado Plurinacional de Bolivia; IDEA Internacional, 2010.

- Estado Plurinacional comunitario autonómico y pluralismo jurídico. In: SOUSA SANTOS, Boaventura; RODRIGUEZ, José Luis Exeni; (Edit.) Justicia indígena, plurinacionalidad e interculturalidad en Bolivia. La Paz: Fundación Rosa Luxemburg/ Abya-Yala, 2012.

- PUENTE, Florencia; LONGA, Francisco. El Alto: los dilemas del indigenismo urbano. Entre la insurrección y el clientelismo. In: (Org.) SVAMPA, Maristella; STEFANONI, Pablo. Bolivia: Memoria, insurgencia y movimientos sociales. EI Colectivo. Buenos Aires: Clacso, 2007.

- QUIJANO, Aníbal "El Fantasma del Desarrollo en América Latina". In: Revista Venezolana de Economía y Ciencias Sociales. Vol. 6, № 2, Caracas, mayoagosto de 2000, pp. 73-90.

. "Colonialidade do poder, eurocentrismo e América Latina". In: LANDER, Edgardo (org.). A colonialidade do saber: eurocentrismo e ciências sociais - perspectivas latino-americanas. Tradução de Júlio César Casarin Barroso Silva. Buenos Aires: CLACSO, 2005. 
El movimiento indígena y las cuestiones pendientes en América Latina. El Cotidiano, Vol. 23, Núm. 151, Universidad Autónoma Metropolitana - Azcapotzalco México, 2008, pp. 107-120.

Des/colonialidad del poder: el horizonte alternativo. Pasado y presente21: Buenos Aires, 2009.

- REINAGA, Fausto. Manifiesto del Partido Indio de Bolivia. La Paz: Ediciones PIB, 1970.

- RIBEIRO, Darcy. O Dilema da América Latina: estruturas de poder e forças insurgentes. Petrópolis: Vozes, 1983a.

O processo civilizatório; estudos de antropologia da civilização; Etapas da evolução sócio-cultural. 7 ed. Petrópolis: Vozes, 1983b.

$-$ América Latina: a pátria grande. Rio de Janeiro: Guanabara dois, 1986

- RODRÍGUEZ-CARMONA. Antonio. El proyectorado. Bolivia tras 20 años de ayuda externa. La Paz: Plural editores, 2009.

- ROJAS, Farit. Entrevistado por Gladstone Leonel da Silva Júnior. La Paz: 22/07/2013.

- ROJAS. Jorge Asbun. El proceso constituyente actual en Bolivia. La constante tensión entre libertad y autoritarismo. Instituto de Investigaciones Jurídicas UNAM. México D.F., $2009 . \quad$ Disponível em: <biblio.juridicas.unam.mx/libros/6/2728/4.pdf>. Acesso em 27 jun. 2012.

- ROJAS, Roberto Laserna; PACHECO, Carlos Miranda; TORRICO, Mario Napoleón Pacheco. Control estatal de recursos naturales y rentismo. In: LASERNA, Roberto et. all. Poder y cambio en Bolivia: 2003-2007. La Paz: Embajada del Reino de los Países Bajos, Fundación PIEB, 2009. 
- SADER, Eder (Org.). Che Guevara: política. São Paulo: Expressão Popular, 2004.

- SANJÍNES, Iván Bascopé. Consulta previa: reto de democracia comunitaria. In: SANTOS, Boaventura de Sousa; RODRIGUEZ, José Luis Exeni; (Edit.) Justicia indígena, plurinacionalidad e interculturalidad en Bolivia. La Paz: Fundación Rosa Luxemburg/ Abya-Yala, 2012.

- SANTAELLA GONÇALVES, Rodrigo. Intelectuais em movimento: o grupo Comuna na construção hegemônica antineoliberal na Bolívia. Dissertação de mestrado. Campinas-SP: UNICAMP, 2013.

- SARTORI, Vitor B. Lukács e a crítica ontológica ao Direito. São Paulo: Cortez Editora, 2010.

- SCHAVELZON, Salvador Andrés. A Assembleia Constituinte na Bolívia: Etnografia do Nascimento de um Estado Plurinacional. Rio de Janeiro: UFRJ/ PPGAS, 2010.

- SEABRA, Raphael L. A primeira revolução do século XXI? Bolivarianismo e Socialismo na Venezuela. Tese de Doutorado. Departamento de Sociologia. Brasília: Universidade de Brasília, 2012.

O capitalismo dependente latino-americano 40 anos depois. Revista Brasileira de Estudos Latino-americanos, v. 3, n. 1, Porto Alegre: UFRGS, out. 2013.

- SILVA, José Afonso. Aplicabilidade das normas constitucionais. $6^{\mathrm{a}}$ ed. 3atiragem, São Paulo: Malheiros Editores, 2004.

- STEFANONI, Pablo. ¿Y quién no querría vivir bien? Encrucijadas del proceso de cambio boliviana. In: Cuadernos del Pensamiento Crítico Latinoamericano. $\mathrm{n}$ ㅇ 53. Buenos Aires: CLACSO, 2012.

- SORUCO. Jorge Luis Soza. El discurso de la "cosmovisión andina": una lectura marxista del "mundo andino". La Paz: Bandera Roja, 2009. 
- SOUSA JÚNIOR, José Geraldo. Ética, Justiça e Direito. In: Novas sociabilidades, novos conflitos, novos direitos. Ed. Vozes. Petrópolis: 1997. Safe, 2011.

Direito como liberdade: o direito achado na rua. Porto Alegre:

- SOUSA SANTOS, Boaventura. A crítica da razão indolente: contra o desperdício da experiência. 4 ed. São Paulo: Cortez, 2002.

Refundación del Estado en América Latina: Perspectivas desde una epistemología del Sur. La Paz: Plural Editores, 2010. Cortez, 2011.

Para uma revolução democrática da justiça. $3^{a}$ ed. São Paulo:

Cotez, 2011.

- TAMBURINI, Leonardo. La jurisdicción indígena y las autonomías indígenas. In: SOUSA SANTOS, Boaventura; RODRIGUEZ, José Luis Exeni; (Edit.) Justicia indígena, plurinacionalidad e interculturalidad en Bolivia. La Paz: Fundación Rosa Luxemburg/ Abya-Yala, 2012.

- TAPIA, Luis. Gobierno Multicultural y democracia directa nacional. In: LINERA, Álvaro Garcia; TAPIA M., Luís; ALCOREZA, Raul Prada. (Org.) La transformación pluralista del Estado. La Paz: Muela del diablo, 2007.

- _ Una reflexión sobre la Idea de Estado Plurinacional. Revista del Observatorio Social de América Latina. Buenos Aires: CLACSO. Año VIII, n. 22, 2007b. $\overline{2009 .}$

Pensando la democracia geopolíticamente. La Paz: Clacso,

La coyuntura de la autonomía relativa del Estado. La Paz: Clacso: Muela del Diablo, 2009b. 
El estado en condiciones de abigarramiento. In: LINERA, Álvaro Garcia; TAPIA M., Luís; ALCOREZA, Raul Prada, CAMACHO, Oscar Vega. (Org.) El Estado. Campo de lucha. La Paz: Muela del diablo, 2010.

- TEJADA, Maria Nela Prada. El diálogo del socialismo con el vivir bien. In: ARKONADA, Katu. (Coord.) Transiciones hacia el vivir bien. $O$ la construcción de un nuevo proyecto político en el Estado Plurinacional de Bolivia. La Paz: Ministerio de Culturas, 2012.

- TICONA, A. Esteban. El thakhi entre los aymara y los quechua o la democracia en los gobiernos comunales. In: TICONA, A. Esteban (Coord.) Los Andes desde los Andes: Aymaranakana, Qhichwanakana, Yatxatawipa, Lup'iwipa. La Paz: Ediciones Yachaywasi, 2003, p. 125-146.

- TRASPADINI, Roberta. Infância Latino-americana pede socorro. Brasil de Fato. São $\quad$ Paulo, 2014.2 Disponível em http://www.brasildefato.com.br/node/27088. Acesso em 16 jan. 2014.

- TUBINO, Fidel. La interculturalidad crítica como proyecto ético-político.

Encuentro continental de educadores agustinos. Lima, 2005. Disponível

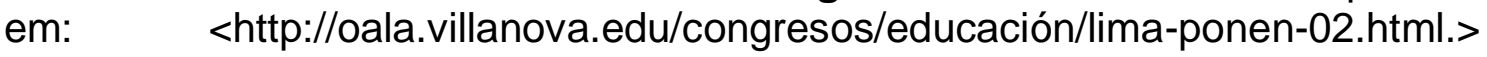
Acesso: 15 jun. 2012.

- UPRYMNI, Rodrigo. Las transformaciones constitucionales recientes en América Latina: tendencias y desafíos. In: El derecho en América Latina: un mapa para el pensamiento jurídico del siglo XXI. (Coord.) César Rodríguez Garavito. Buenos Aires: Siglo Veintiuno Editores, 2011.

- URIOSTE, Miguel. La expansión del agronegócio em Bolivia. Nueva Crónica y buen gobierno. Número 133, La Paz, 29 out. 2013. Disponível em: http://www.nuevacronica.com/economia/la-expansion-del-agronegocio-enbolivia-/. Acesso em: 08 mai. 2014.

- VAZQUEZ, Adolfo Sánchez. Filosofia da Práxis. São Paulo: Expressão Popular, 2007. 
- VALACÁRCEL, Luis E. Prólogo a Tempestad en Los Andes. Lima, 1927. $2000 . \quad$ Disponível em: <http://www.marxists.org/espanol/mariateg/1927/oct/10.htm>. Acesso em: 28 jun. 2011.

- VENEZUELA. Constituição (1999). Constituición de la República Bolivariana de Venezuela: promulgada em 15 de dezembro de 1999. Caracas: Talleres gráficos de la Asamblea Nacional, 2005.

- VEGA CAMACHO, Oscar. Reflexiones sobre la transformación pluralista In: GARCIA LINERA, Álvaro; TAPIA M., Luís; ALCOREZA, Raul Prada. (Org.) La transformación pluralista del Estado. La Paz: Muela del diablo, 2007.

. Al sur del Estado. In: GARCIA LINERA, Álvaro; TAPIA M., Luís; ALCOREZA, Raul Prada, VEGA CAMACHO, Oscar. (Org.) El Estado. Campo de lucha. La Paz: Muela del diablo, 2010.

$23 / 07 / 2013$.

Entrevistado por Gladstone Leonel da Silva Júnior. La Paz:

- VIAÑA, Jorge. Entrevistado por Gladstone Leonel da Silva Júnior. La Paz: 23/07/2013.

- VICIANO PASTOR, Roberto. Análisis critico del proceso constituyente en Bolivia y Ecuador. Associação Americana de Juristas. Buenos Aires, 2008, Disponível em: http://www.aaj.org.br/confmagistr.htm. Acesso em 28 jun. 2012.

- WALLERSTEIN, Immanuel. The Modern World System. New York: Academic Press, 1974.

- WALSH, Catherine. Interculturalidad, Plurinacionalidad y Decolonialidad: las insurgencias político-epistémicas de refundar el Estado. Tabula Rasa. no.9, Bogotá, 2008, p. 131-152.

Interculturalidad, estado, sociedad: luchas (de)coloniales de nuestra época. Quito: Universidad Andina Simón Bolívar; Abya-Yala, 2009a. 
Interculturalidad crítica y pedagogía de-colonial: apuestas (des)de el in-surgir, re-existir y re-vivir. Vera Candau (Edit.) In: Educação Intercultural hoje en América latina: concepções, tensões e propostas. Rio de Janeiro: Educação on-line, Departamento de Educação PUC, 2009b.

- WOLKMER, Antônio Carlos; FAGUNDES. Lucas Machado. Tendências contemporâneas do constitucionalismo latino-americano: Estado plurinacional e pluralismo jurídico. Pensar, Fortaleza, v. 16, n. 2, p. 371-408, jul./dez. 2011.

- YAKSIC, Fabian II. Asamblea Legislativa Plurinacional: desafíos, organización, atribuciones y agenda legislativa. La Paz: Muela del Diablo, 2010.

- ZAVALETA MERCADO, René. Lo nacional-popular en Bolivia. 2 ed., La Paz: Plural Editores, 2008.

. Las masas en noviembre. In: La autodeterminación de las masas. compilador Luis Tapia Bogotá: Siglo del Hombre Editores y Clacso, 2009.

- ZIZEK, Slavoj. Multiculturalism, or the Cultural Logic of Multinational Capitalism., New Left Review, 225. London. 1997. 
ANEXOS 
ANEXO A - Ata de cômputo nacional das eleições gerais de 2005.

\author{
Corte Nacional Electoral
}

I. TOTAL DE CIUDADANOS INSCRITOS, VOTOS EMITIDOS, VÁLIDOS, NULOS Y EN BLANCO, POR DEPARTAMENTOS $Y$ EN TODA LA REPÚBLICA $Y$ DETALLE DE VOTOS VÁLIDOS OBTENIDOS POR CADA PARTIDO POLÍTICO, AGRUPACION CIUDADANA, PUEBLO INDIGENA O ALIANZA, POR DEPARTAMENTO.

1. RESULTADOS NACIONALES.

\begin{tabular}{|l|r|r|}
\hline \multicolumn{1}{|c|}{ DETALLE } & TOTAL & Porcentaje \\
\hline Ciudadanos inscritos & 3.671 .152 & \\
\hline Votos emitidos & 3.102 .417 & $100 \%$ \\
\hline Votos válidos & 2.873 .801 & $92.631 \%$ \\
\hline Votos nulos & 104.570 & $3.371 \%$ \\
\hline Votos en blanco & 124.046 & $3.998 \%$ \\
\hline \multicolumn{2}{|c|}{ VOTOS VALIDOS OBTENIDOS POR CADA PARTIDO POLITICO } & ALIANZA \\
\hline Frente de Unidad Nacional (UN) & 224.090 & $7.79 \%$ \\
\hline Frente Patriótico Agropecuario de Bolivia (FREPAB) & $\mathbf{8 . 7 3 7}$ & $\mathbf{0 . 3 0 \%}$ \\
\hline Movimiento Indigena Pachakuti (MIP) & 61.948 & $2.16 \%$ \\
\hline Nueva Fuerza Republicana (NFR) & 19.667 & $0.68 \%$ \\
\hline Movimiento Al Socialismo (MAS) & 1.544 .374 & $53.74 \%$ \\
\hline Movimiento Nacionalista Revolucionario (MNR) & 185.859 & $6.47 \%$ \\
\hline Unión Social de los Trabajadores de Bolivia (USTB) & 7.381 & $0.26 \%$ \\
\hline Poder Democrático y Social (PODEMOS) & $\mathbf{8 2 1 . 7 4 5}$ & $28.59 \%$ \\
\hline
\end{tabular}

2. RESULTADOS DEPARTAMENTALES.

2.1. CÓMPUTO PARA PRESIDENTE, VICEPRESIDENTE, SENADORES Y DIPUTADOS PLURINOMINALES.-

2.1.1. Cómputo Departamental de Chuquisaca.

\begin{tabular}{|l|r|}
\hline \multicolumn{1}{|c|}{ DETALLE } & TOTAL \\
\hline Ciudadanos inscritos & $\mathbf{2 1 4 . 4 0 9}$ \\
\hline Votos emitidos & $\mathbf{1 7 7 . 3 1 0}$ \\
\hline
\end{tabular}

\title{
-2 .
}

Avenida Sánchez Lima N* 2482, esquina Pedro Salazar Teléfonos: 2424221 -2422338 FAX: 2416710 
ANEXO B - Gazeta oficial da Bolívia com a decretação do referendo amparado pela lei 3850 .

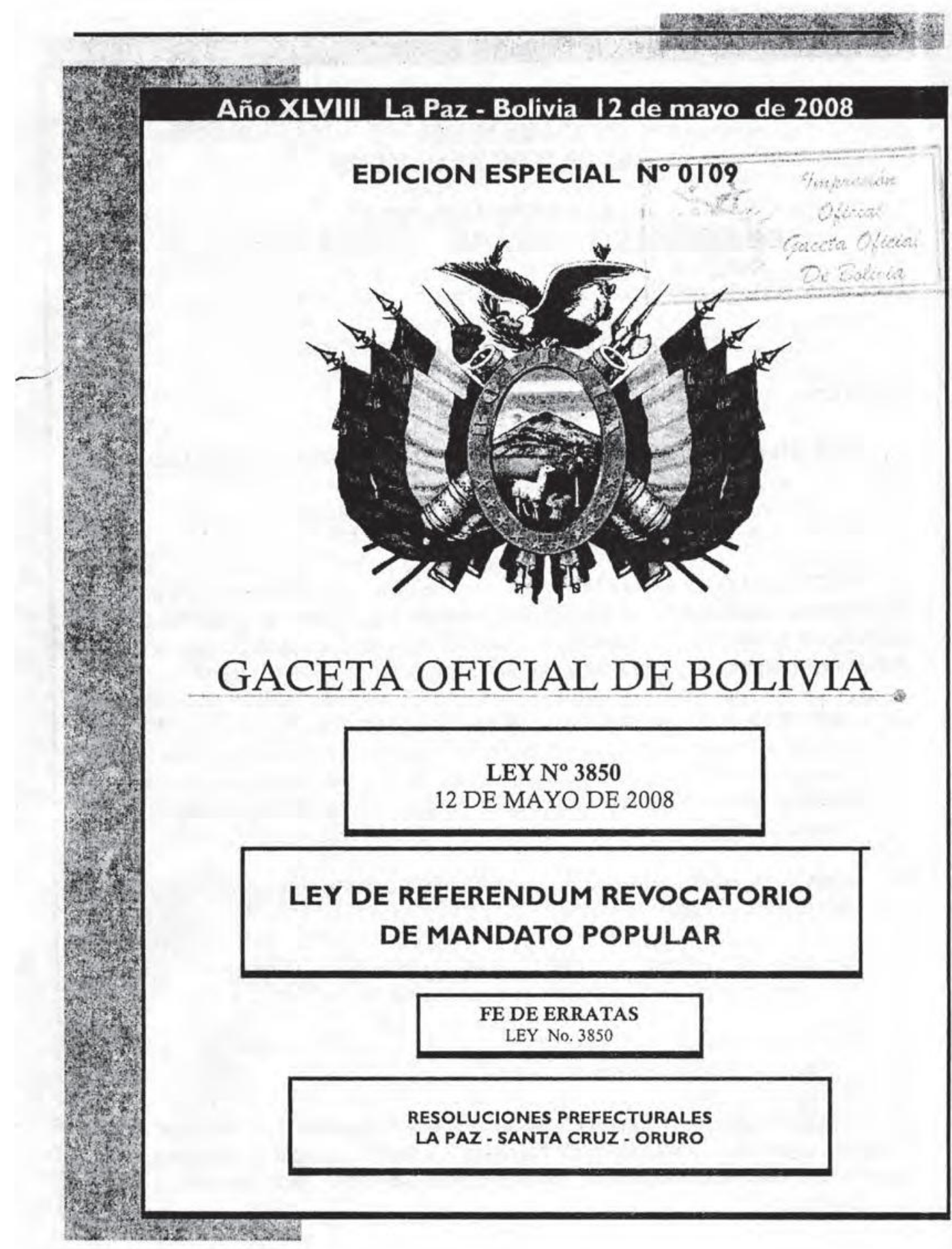




\section{ANEXO C - Documento assinado pelas organizações pelo Pacto de Unidade.}

\section{AL PUEBLO BOLIVIANO}

BI Pacto de Unidad conformado por las Organizaciones CSUTCB, CSCB, FNMCB-BS y CONAMAQ y CIDOB, se dirigen al Pueblo boliviano.

Contra la arremetida, de la Derecha encaramada hoy en los Poderes Constituidos, como la Corte Superior de Distrito de Justicia de Chuquisaca, que en su afan de hacer fracazar, este proceso de cambios a través de la Asamblea Constituyente, esta apoyando las inciativas de quienes no desean cambios a favor de los pueblos indigenas originarios campesinos, sino mantener el actual estado que favorece los intereses las oligarquias nacionales $y$ transnacionales.

I:n eske ámbito, han provocado que la directiva se pronuncic, solicitando subsanar supuestos errores, del informe final de la Comisión Visión de Pals, cl cual tiene la intención de desconocer el Estado Plurinacional y la presencia de nuestros pueblos indigenas originarios campesinos en este proceso histórico de cambios.

Que según el Arículo i del reglamento de la Asamblea Constituyente, esta es declarada Originaria y por tal es independiente de los poderes constituidos y plenipotenciaria ya que esta transformando las actuales estructuras del vicjo cstado colonial y monocultural.

P’or tanto, ningún Poder Constituido puede intervenir en las decisiones ni en el proceso de la Asamblea Constituyente, menos el Poder Judicial, hoy desprestigiado y marcado por el prevadicato y la corrupción; cuya acción maliciosa que favoreció los interese de la derecha está lecionando el Proceso Constituyente.

Nosotros reunidos, en magna reunión de los pueblos y naciones indígenas originarios campesinos y comunidades interculturales, resolvemos, apoyar firmemente el informe final de la Comisión Visión de Pais, no permitiendo niguna modificación de forma o de fondo y que cualquier complementación sea definida en la plenaria de la Asamblea, según lo establece el reglamento.

Solicitamos a la comisión Visíón de Pais que incluya en su informe a las comunidades interculturales en la caracterización dxe pueblo Boliviano.

Recomendamos que las instancia orgánicas de la Asamblea Constituyente, en especial la Directiva, se ajuste a las competencia establecidas en su reglamento y apoye contundentemente los procesos de cambios que se están generando.

En caso de no cumplir estas demandas, nuestras organizaciones asumiran medidas de hecho en defensa del Estado Pluriunacional y la inclusión de las propuestas de los pueblos y naciones idigenas originarias campesinas y comunidades interculturales.

Sacre, 28 de junio de 2007.
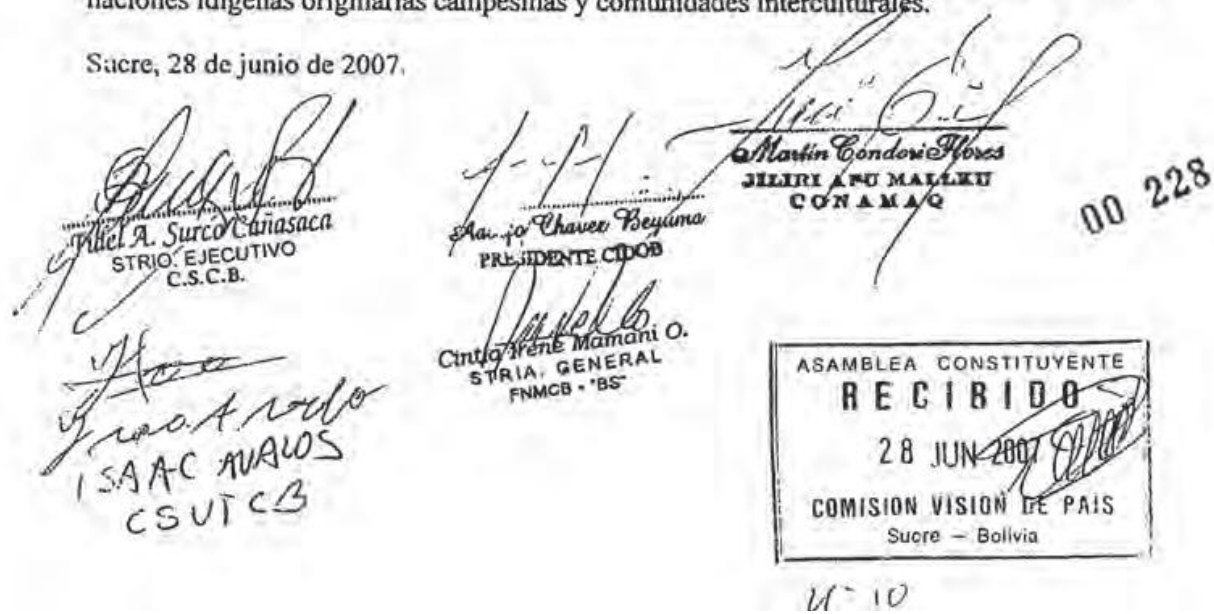
ANEXO D - Assembleia Nacional de Organizações Indígenas Originarias, Campesina y de Colonizadores da Bolívia. 05 de agosto de 2006.

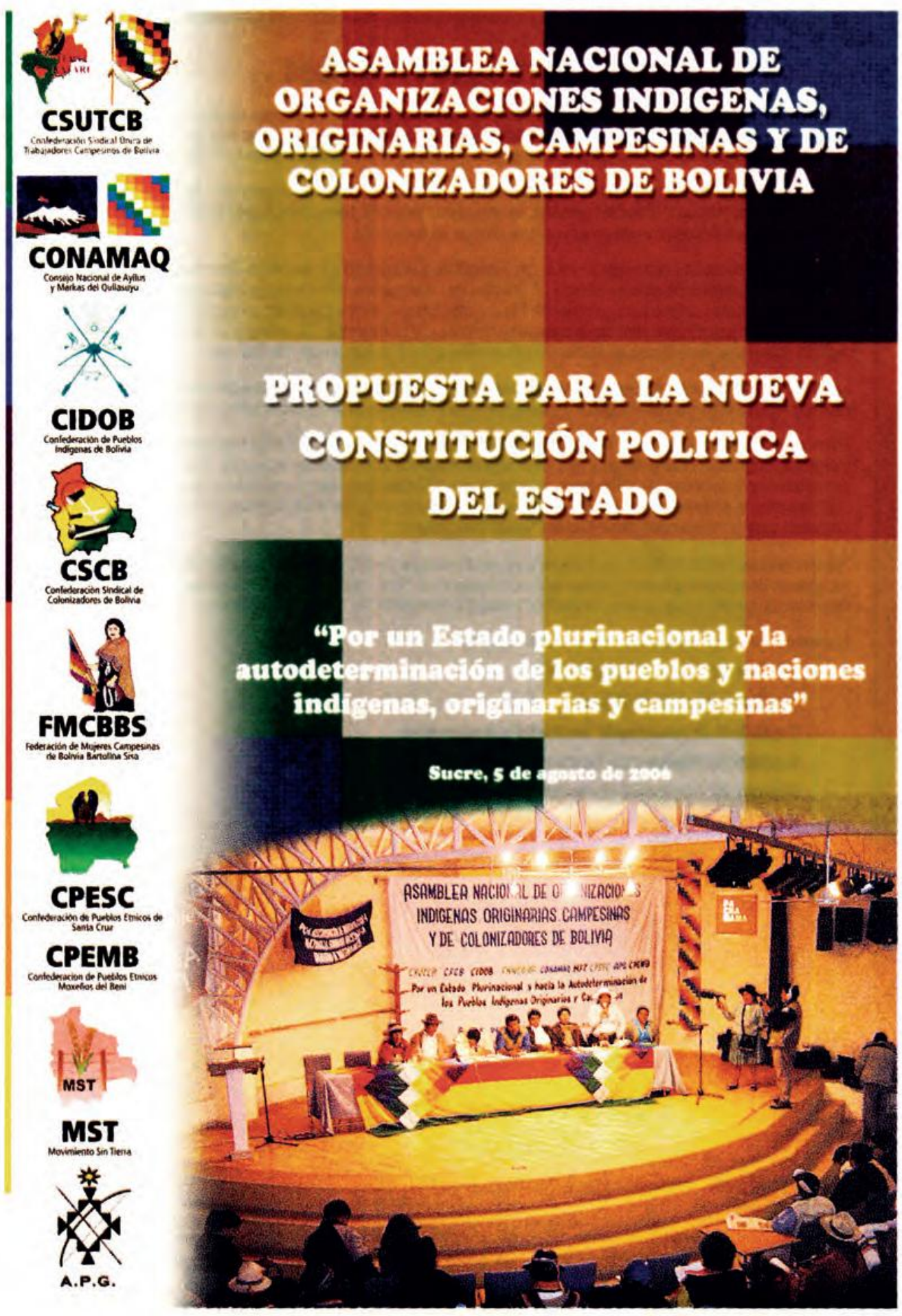




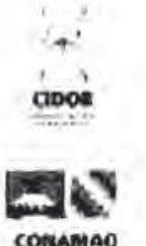

CONAMAQ

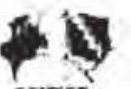

csurce

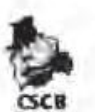

$\triangle C B$
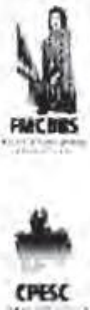

Cremas

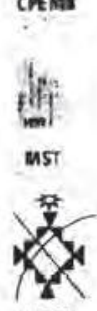

A.P.G.

Señor

Evo Morales Ayma

PRESIDENTE CONSTITUCIONAL DE LA REPÚBLICA DE BOLIVIA

Presente.-

De nuestra mayor consideración:

Las organizaciones indígenas, campesinas, originarias y de colonizadores de Bolivia, reunidos en ASAMLEA NACIONAL en la ciudad de Sucre capital de la República de Bolivia en fechas 3 al 5 de Agosto de 2006. concluimos la elaberación y la consensuación de la propuesta para su consideración por los constituyentes en la Asamblea Constituyente para la redacción final del texto de la nueva Constitución Politica del Estado

En ella expresamos los planteamientos centrales y nuestra visión sobre la construcción de un nuevo proyecto de vida para vivir bien en armonia con la naturaleza, consolidando los derechos colectivos de los pueblos indigenas. campesinas, originarios y otros sectores sociales del pais.

Estamos seguros que ésta propuesta tiene su respaldo social; por ello, nosotros mantendremos una vigilancia y,aryillización permanente para que nuestros planteamientos se incluyan en ferto de tálegva carta magna de Bolivia:

Reinteamientos se incluyan en equ te to

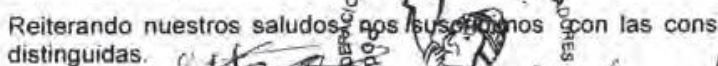
distinguidas.

$$
\text { tor Secrotarig Ejeccurivo de }
$$

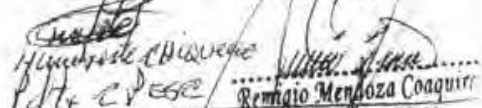

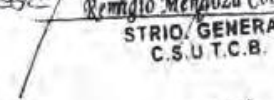

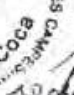

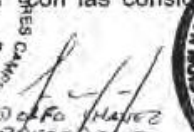
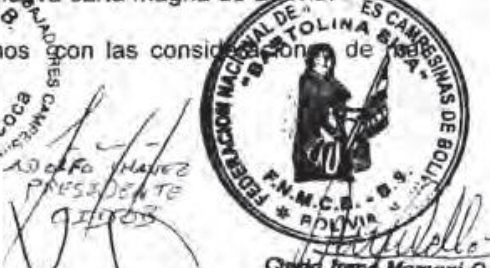

artad trend Afamani $O$ TRIA. GENERAL

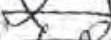

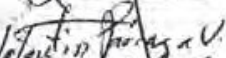
Funce. - Bs:<smiles>[As]=[W]</smiles>

C. 5 . 8

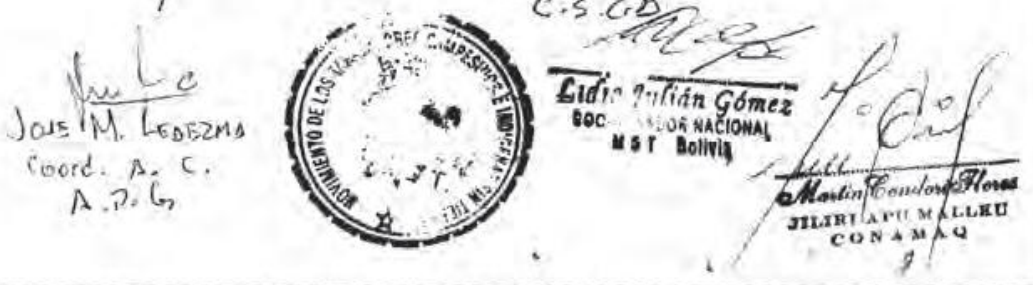




\section{ANEXO E - Despacho do comando da Polícia nacional à Presidenta da Assembleia constituinte}
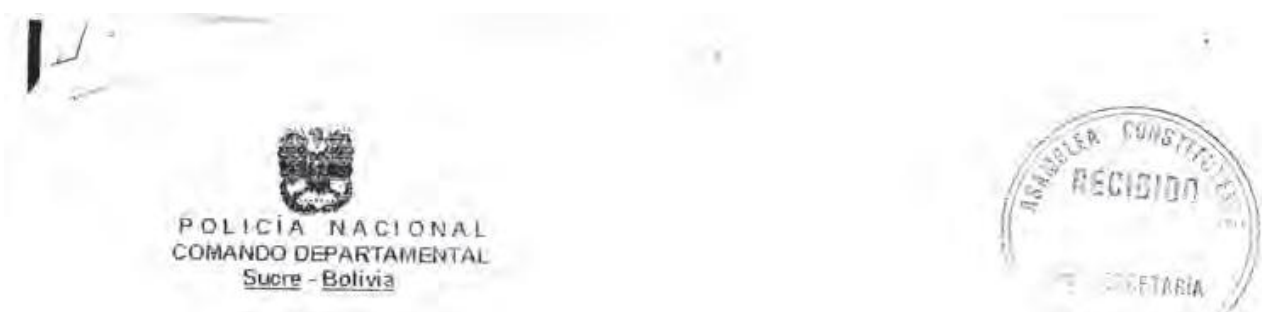

DIRFCCIÓN DESPACHO COMANDO

DEPARTAMENTO: SECRETARIA GRAL

CITE: No 0382/07

Sucre, 23 de Agosto de 2007

Señora

Silvia Lazarte Flores

H. PRE SIDENTA A SAMBLE CONSTIIUYYNIE

Presente-

Señora Presidenta

Mediante el presente, me permito diricirme respefuoso a su digna autoridad, para hacerle conocer, que ante los conflictos sociales ocumidos ol dia de ayer miercoles 22 del presente, lamentablemente los marchistas rebasaron la segundad en torno al reatro Mariscal, donde se fuvo que hacer uso de agentes quimicos, por lo que se remite a usted Informes de los seinores jefes Poltciales que ambaron del interior de pais, al mando de los grupos consignados de Seguridad. Asimismo, informe del Comandante de la USPAC.

Con este motivo saludo a usted, con tas consideraciones más distinguidas.

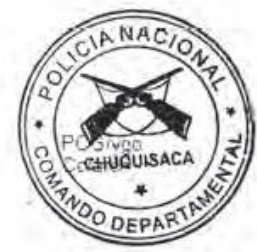

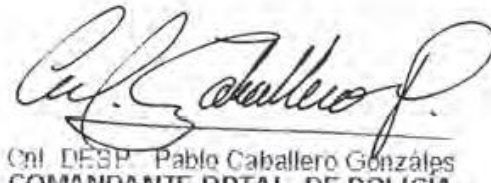

COMANDANTE DPTAL. DE POLICIA

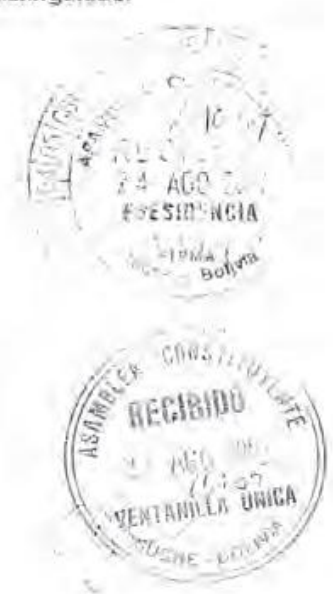

no 


\title{
ANEXO F - Acordo final da mesa de diálogo nacional estabelecida.
}

\author{
Diálogo Nacional \\ ACUERDO FINAL
}

Diez y ocho días después de la instalación del Diálogo Nacional en la ciudad de Cochabamba, el Gobierno Nacional y los prefectos de los departamentos de Beni, Chuquisaca, Cochabamba, La Paz, Oruro, Pando, Potosí, Santa Cruz y Tarija, cumpliendo la Agenda fijada por cl documento titulado "Bases para instalar el Diálogo y construir un gran Acuerdo Nacional" y en presencia de los delegados internacionales y representantes de las Iglesias que han acompañado el proceso de diálogo cn su calidad de facilitadores y testigos, acuerdan:

1: Aprobar el Informe Final presentado por Ias mesas "Impuesto Directo a los Hidrocarburos - IDH" (Mesa Nro. 1) y "Constitución y Autonomins" (Mesa Nro. 2).

2: Garantizar la convocatoria congresal al Referéndum Dirimidor y Constituyente del proyecto de nucva Constitución Politica del Estado asumiendo que los acuerdos alcanzados en el Diálogo Nacional recogen las demandas autonómicas de los departamentos de Beni, Pando, Santa Cruz y Tarija.

Cochabamba, domingo 5 de-petubre, 2008 :
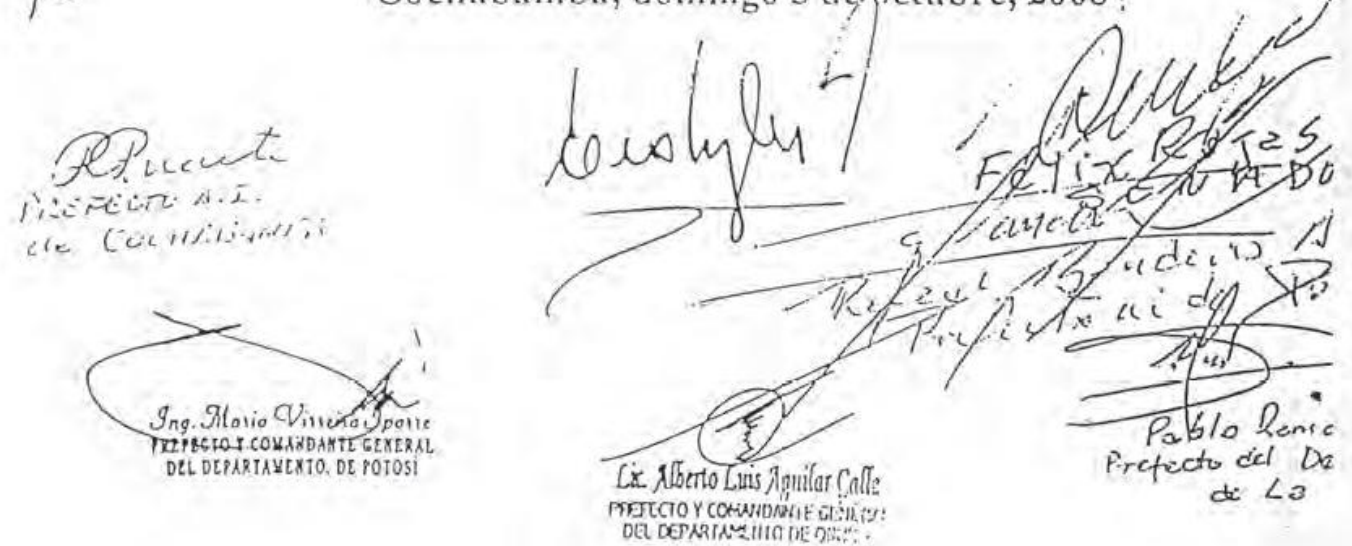


\section{ANEXO G - Cédula do referendo que limitou a propriedade à 5 mil hectares no máximo e aprovou a Constituição}

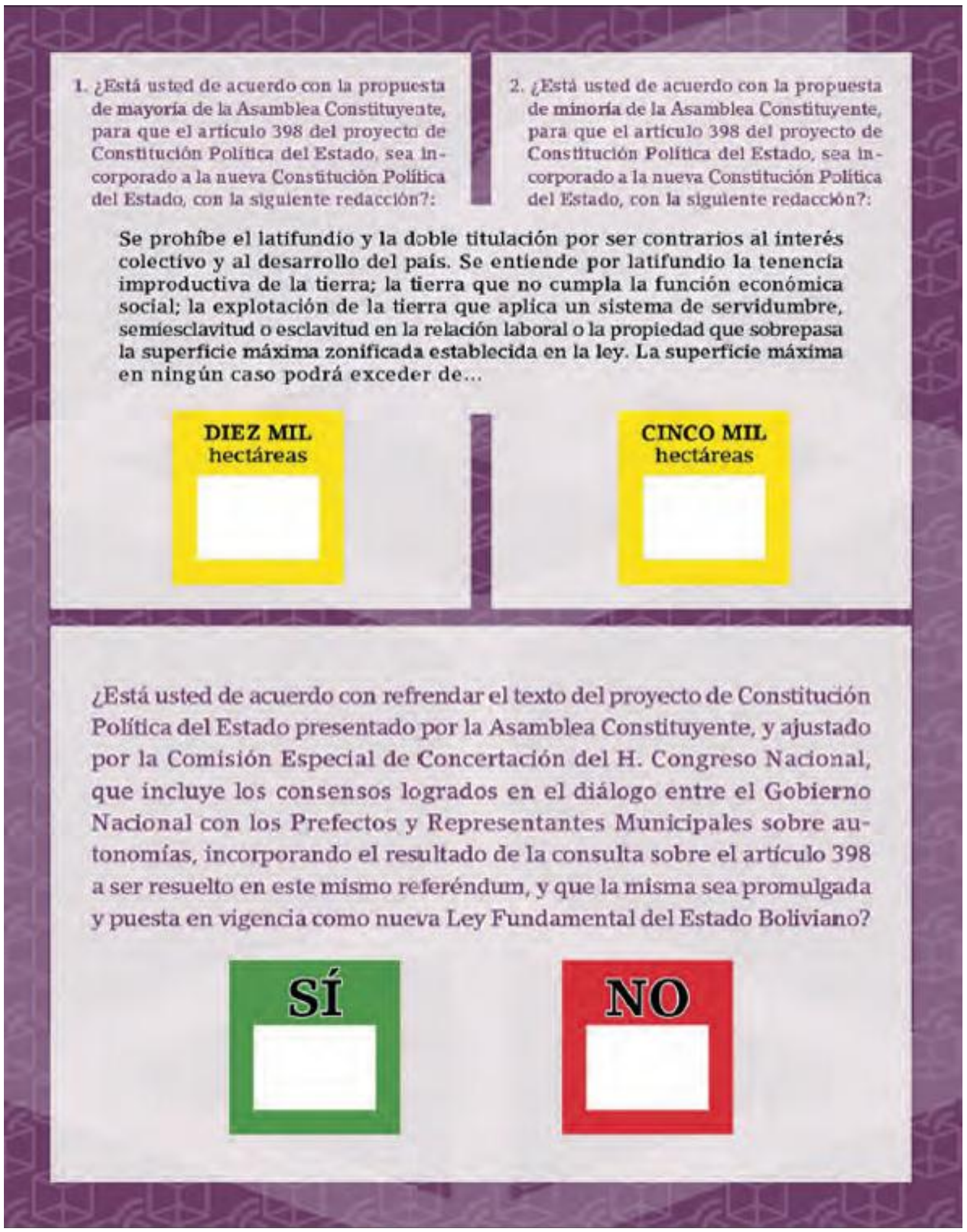




\section{ANEXO H - Acordo sobre o Sistema Econômico na Constituição, reconhecendo a economia plural. La Paz, 04 de outubro de 2007.}

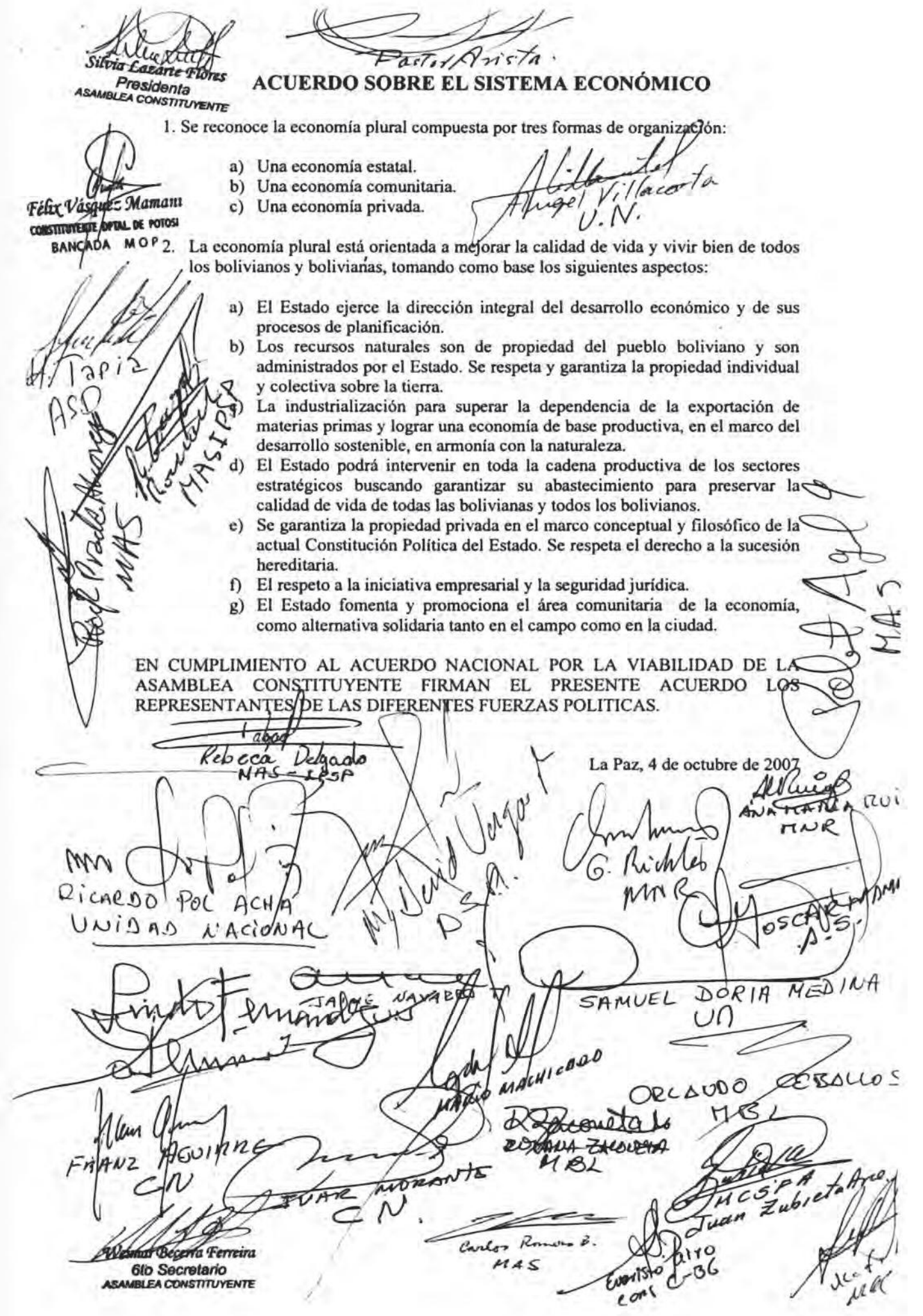


ANEXO I - Distribuição departamental da população de acordo com a sua condição étnico-linguística

\section{BOLIVIA 2001: DISTRIBUCIÓN DEPARTAMENTAL DE LA POBLACIÓN SEGÚN CONDICIÓN ÉTNICO-LINGÜÍSTICA}

(Porcentajes) Fuente: Molina, 2005.

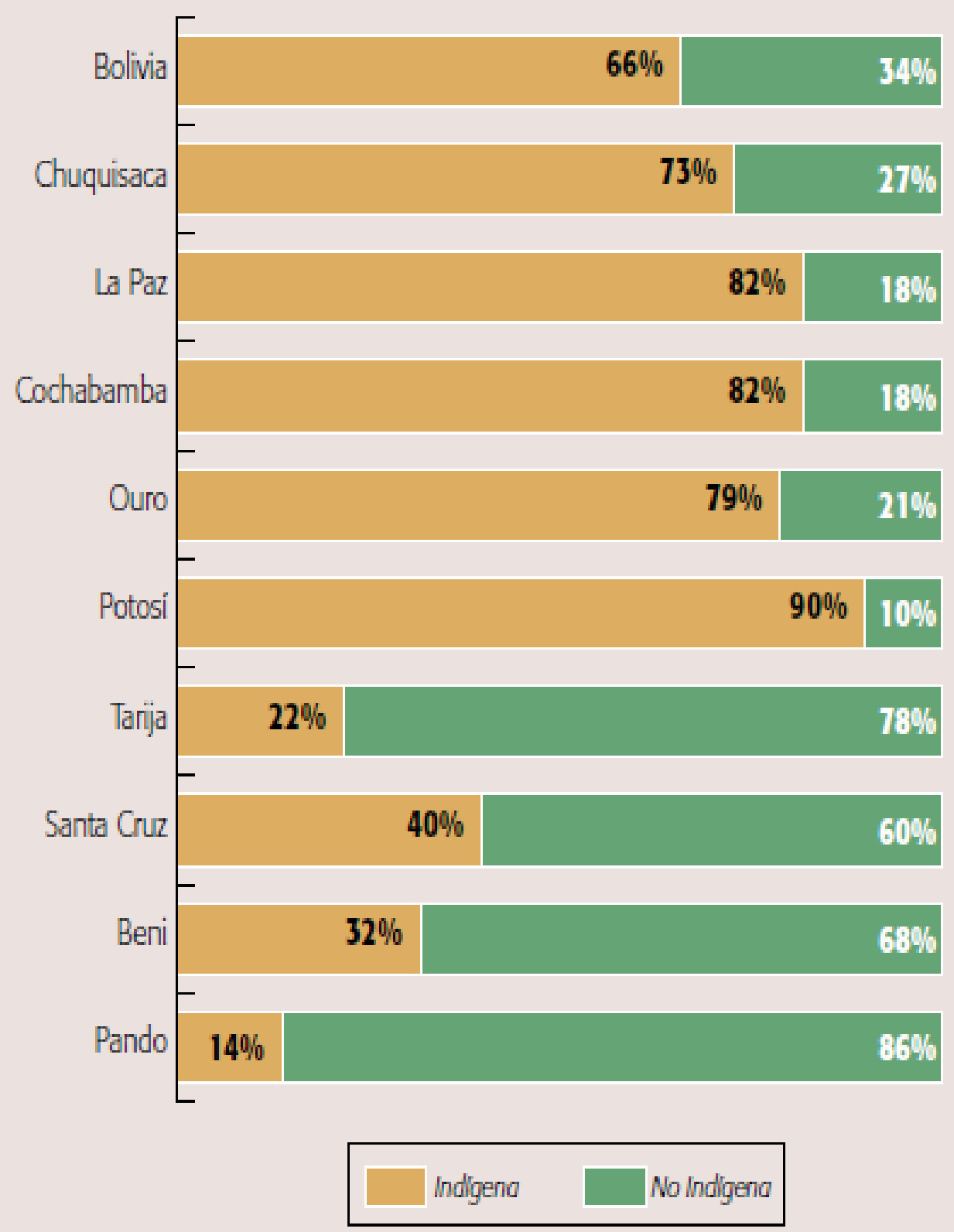


ANEXO $\mathrm{J}$ - Mapa, ainda do início dos anos 2000 , que indica as áreas na Bolívia formadas por Terras Comunitárias de Origem (TCO).

\section{TierRas Comunitarias de ORIgen (TCO)}

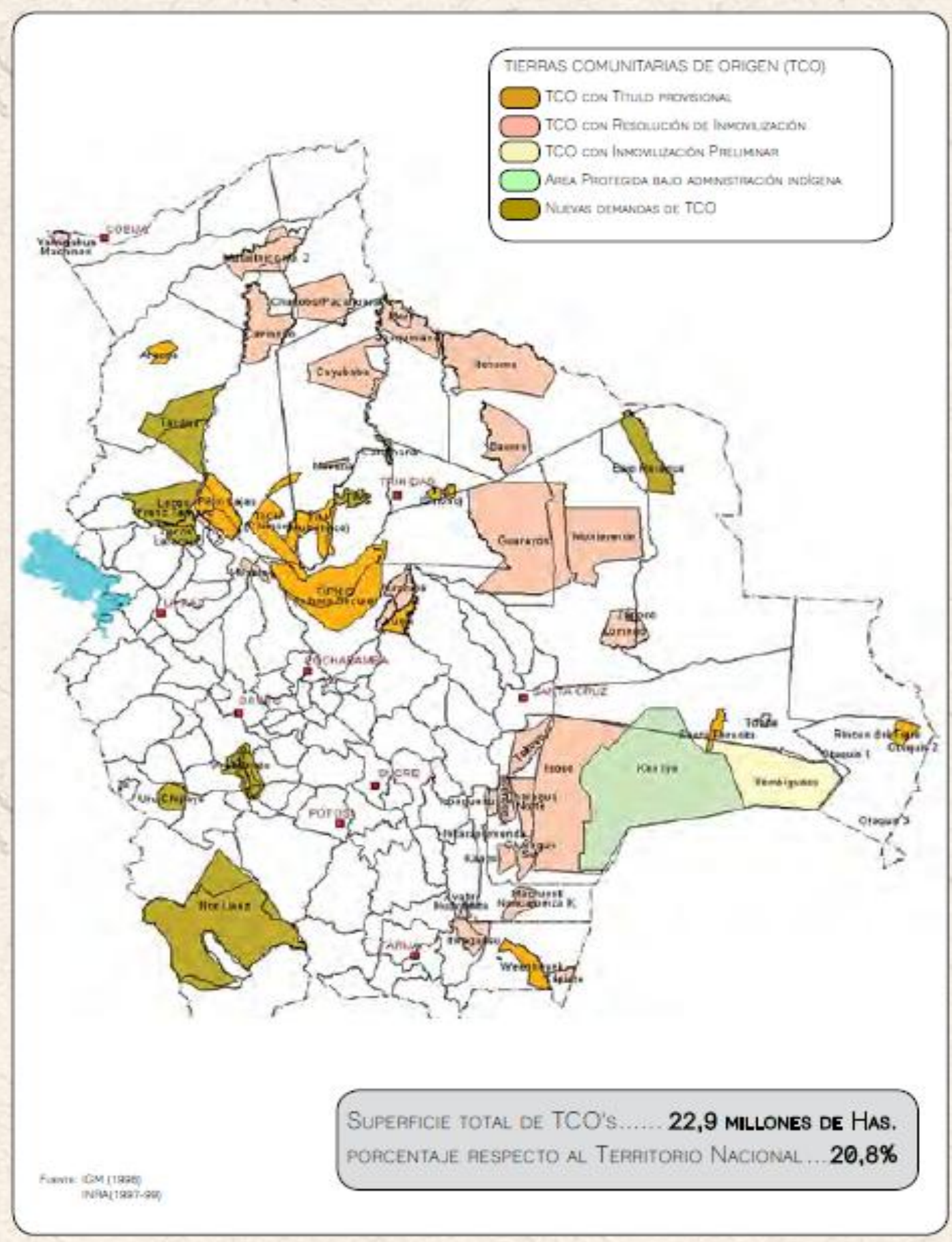


ANEXO $L$ - Membros de povos e nações indígenas componentes das Assembleias Legislativas Plurinacional, Departamental e Regional do Chaco.

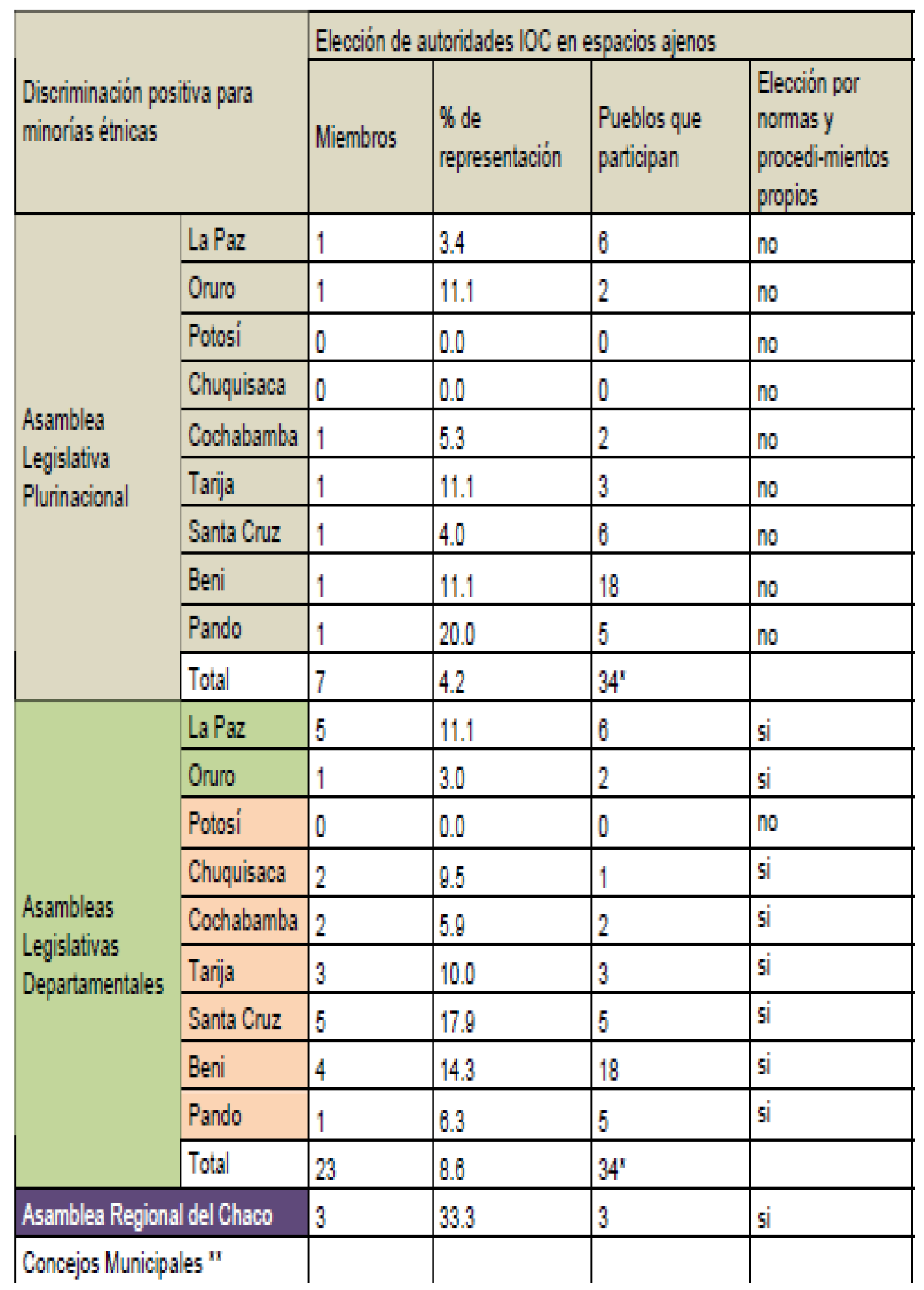


ANEXO M - Autoridades Judiciais eleitas no sufrágio de 2011.

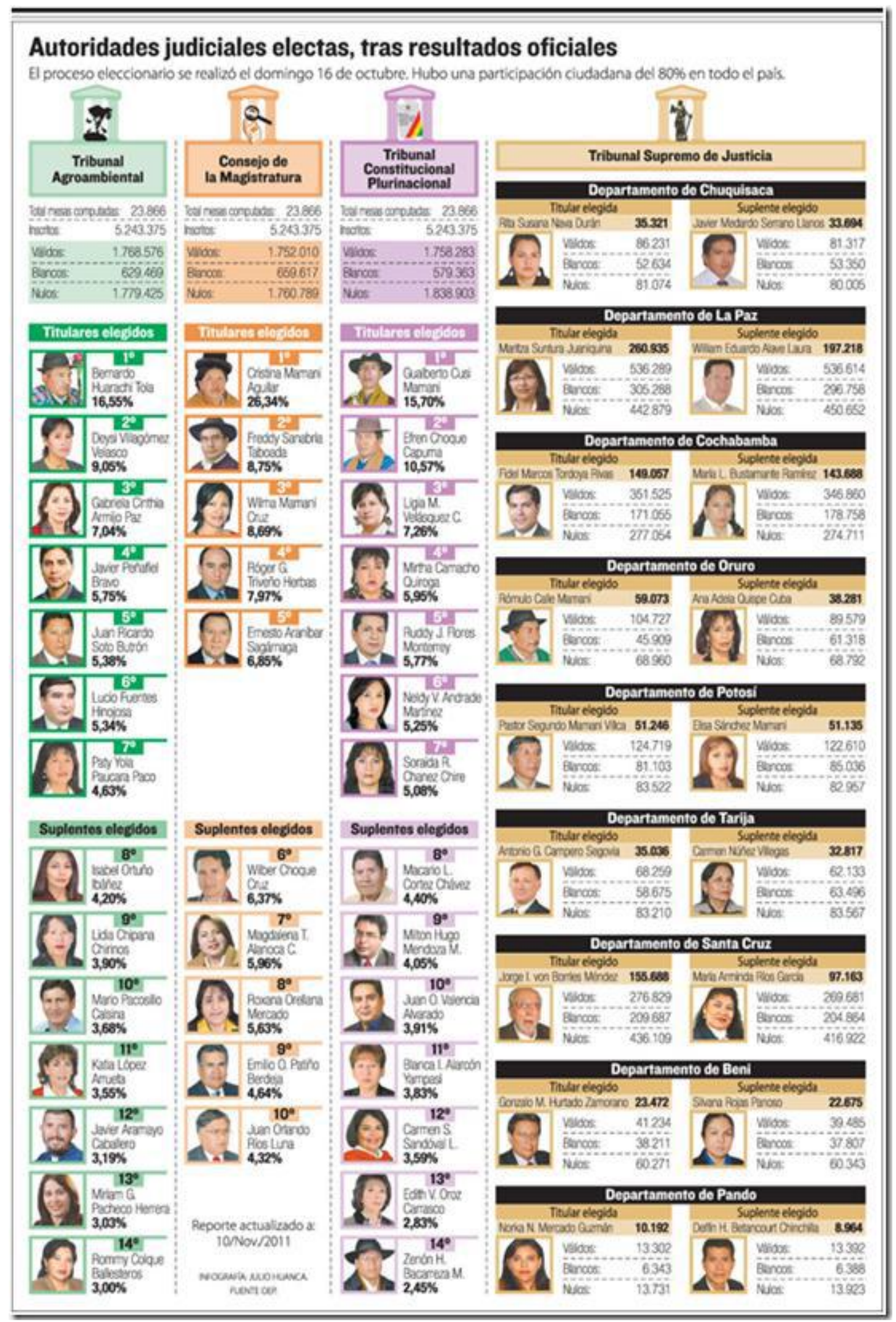

